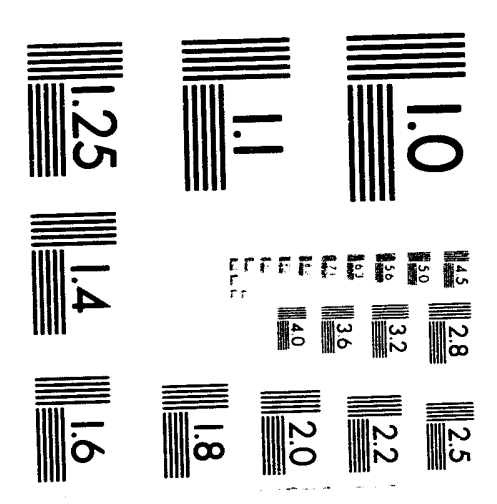



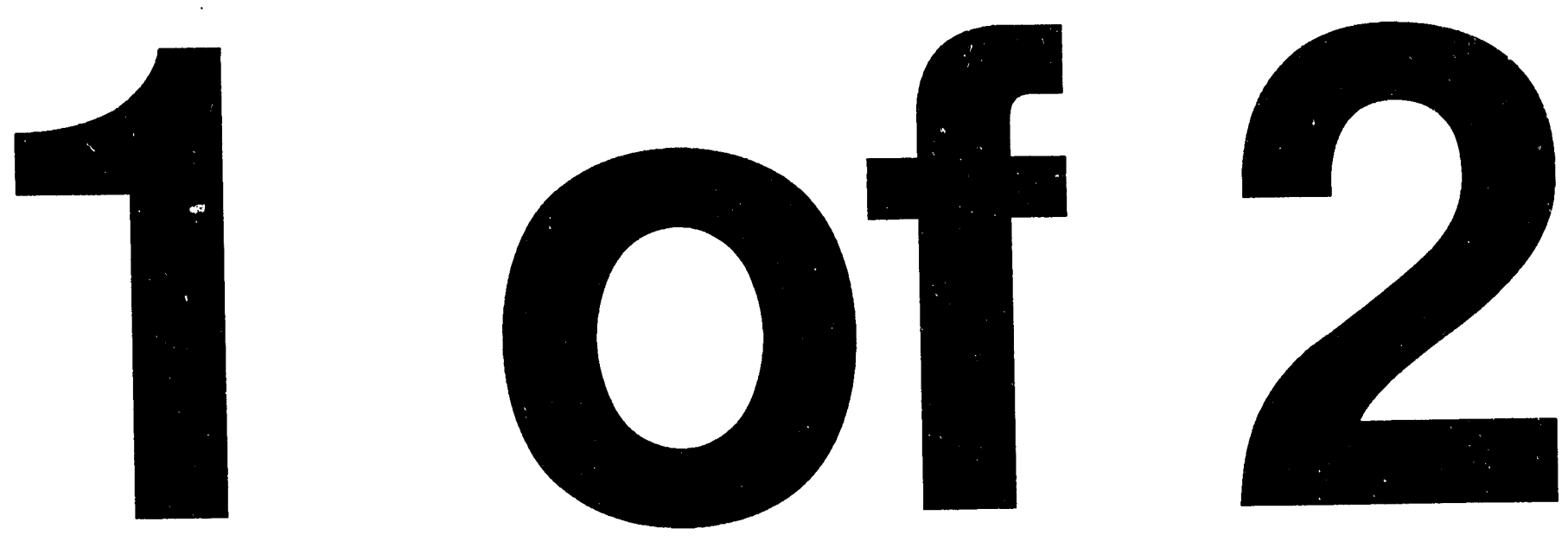


\section{BASELINE RISK ASSESSMENT OF GROUNDWATER CONTAMINATION AT The Uranium Mill Tallings Site Near Gunnison, Colorado}

\section{December 1993}

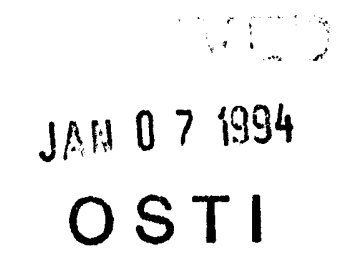

\section{DISCLAIMER}

This report was prepared as an account of work sponsored by an agency of the United States Neither the United States Government nor any agency thereof, nor any of their This employees, makes any warranty, express or implied, or assumes any legal inparatus, product, or bility for the accuracy, completeness, or usefulness of any information, appaned rights. Referprocess disclosed, or represents that its use would not infringe privatel trade name, trademark, ence herein to any specific commercial product, process, or service by trade name, trat, recommanufacturer, or otherwise does not necessarily constitute or imply its endorem. The views mendation, or favoring by the United States Government or any agency therect those of the and opinions of authors expressed herein do not

United States Government or any agency thereof. 


\section{INTENDED FOR PUBLIC RELEASE}

This report has been reproduced from the best available copy. Available in paper copy and microfiche.

Number of pages in this report: 154

DOE and DOE contractors can obtain copies of this report from:

Office of Scientific and Technical Information

P.O. Box 62

Oak Ridge, TN 37831

(615) 576-8401

This report is publicly available from:

National Technical Information Service

Department of Commerce

5285 Port Royal Road

Springfield, VA 22161

(703) 487-4650 
DOE/AL/62350-57D

REV. 0

\section{BASELINE RISK ASSESSMENT OF GROUNDWATER CONTAMINATION AT THE \\ URANIUM MILL TAILINGS SITE \\ NEAR GUNNISON, COLOKADO}

December 1993

Prepared for

U.S. Department of Energy

UMTRA Project Office

Albuquerque, New Mexico

Prepared by

Jacobs Engineering Group Inc.

Albuquerque, New Mexico 


\section{CITIZENS' SUMMARY}

This Baseline Risk Assessment of Groundwater Contamination at the Uranium Mill Tailings Site Near Gunnison, Colorado evaluates potential impacts to public health or the environment resulting from groundwater contamination at the former uranium mill processing site. The tailings and other contaminated material at this site are being placed in an off-site disposal cell by the U.S. Department of Energy's (DOE) Uranium Mill Tailings Remedial Action (UMTRA) Project. Currently, the UMTRA Project is evaluating groundwater contamination. This is the second risk assessment of groundwater contamination at this site. The first risk assessment was performed primarily to evaluate existing domestic wells. This risk assessment evaluates the most contaminated monitor wells at the processing site. It will be used to assist in determining what remedial action is needed for contaminated groundwater at the site after the tailings are relncated.

Many domestic wells downgradient of the processing site have been contaminated by siterelated constituents. However, bottled water is available to all residences that are potentially affected by groundwater contamination from the processing site while a public water supply is being built. Because residents will keep their domestic wells for nonhousehold uses, there is a potential for exposure to contaminants in groundwater by using the water for domestic animals or irrigation. The potential exists for these animals and plants to accumulate groundwater contaminants and for people to be exposed by drinking milk and eating meat and garden produce.

This risk assessment follows an approach outlined by the U.S. Environmental Protection Agency (EPA). The first step is to evaluate groundwater data collected from monitor wells at the site. Evaluation of these data showed that the main contaminants in the groundwater are cadmium, cobalt, iron, manganese, sulfate, uranium, and some of the products of radioactive decay of uranium.

The next step in the risk assessment is to estimate how much of these contaminants people would be exposed to if they drank from a well installed in the contaminated groundwater at the former processing site. Because the contaminant concentrations vary each time a well is sampled and because people vary in how much they weigh and drink, this risk assessment uses probability distributions to determine how much of each contaminant would likely be ingested if someone installed a well at the site. The probability distriburions describe how likely it is that something will happen. For example, based on population survey data, probability distributions can describe what percentage of people drink a half-gallon of water each day and what percentage drink only one cup of water each day. Ingestion of contaminants could also occur from drinking milk and eating meat from domestic animals grazed and watered with contaminated groundwater, eating garden produce watered with contaminated groundwater, and eating fish from surface water bodies in the site vicinity.

The estimated amounts of contaminants that people might take from these routes are then compared to the toxic effects these contaminant levels might cause. Based on this analysis, no adverse health effects would be expected following ingestion of milk and meat from animals grazed and watered on the pastureland downgradient of the site or from 
ingestion of garden produce watered with contaminated groundwater. Ingestion of fish also would not be expected to represent a hazard to humans. However, direct consumption of the groundwater from the former processing site could represent a concern.

The most significant health hazards in the groundwater at the Gunnison mill site are manganese and iron. The manganese levels at the former mill site are at levels that have been reported elsewhere to cause central nervous system problems and Parkinson's-like effects when chronically ingested. The levels of iron in groundwater at the former mill site are at levels that have been reported elsewhere to cause effects ranging from increased skin pigmentation to liver damage and diabetes following long-term drinking water exposure. This contaminated groundwater at the site is not currently being used for domestic purposes.

Other contaminants that occur in the groundwater at levels associated with adverse health effects are sulfate and possibly uranium. Sulfate intake from drinking groundwater within approximately 4000 feet (1200 meters) downgradient (southwest) of the site would cause severe diarrhea that could lead to dehydration in infants. The levels of uranium in groundwater as far from the site as the Gunnison River would result in an intake level from drinking water above the EPA's acceptable level of 1 in 10,000, but below levels reported to result in adverse health effects. The additional cancer risk from ingesting contaminated groundwater for a lifetime would be 3 in 10,000 for groundwater containing the average radionuclide concentrations measured in monitor wells at the mill site.

This risk assessment also evaluated potential effects on livestock if the groundwater were used to water them. Based on available information, sulfate is the only contaminant that could represent a hazard to livestock. The sulfate concentrations near the mill site are high enough to cause diarrhea in animals if it is used as the sole source of drinking water. Several contaminants could not be evaluated because information on drinking water concentrations that would be protective of livestock is not available.

Based on data and criteria available for a number of contaminants of concern, no ecological threat exists to plants that may have roots in contact with soil saturated with the most contaminated groundwater in the alluvial aquifer. Potential use of this groundwater would not be suitable for continuous irrigation of crops due to cobalt, iron, and manganese levels. This groundwater vould also not be suitable as a body of water for fish to live in. Howevel, the available surface water and sediment data from the water bodies in the site vicinity suggest that contaminated groundwater from the site has not adversely affected the surface water and sediment quality.

A long-term groundwater monitoring plan has been proposed for the Gunnison site and vicinity. As additional water quality data are collected and interpreted, the monitoring plan will be updated annually to provide ongoing protection for public health and the environment, including future groundwater monitoring of private domestic wells in the Dos Rios subdivision. 
TABLE OF CONTENTS

Section

Page

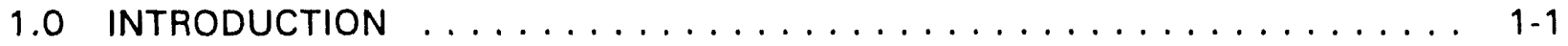

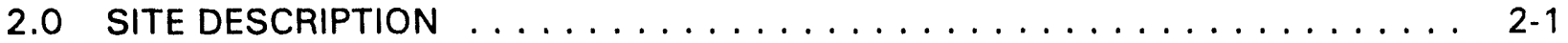

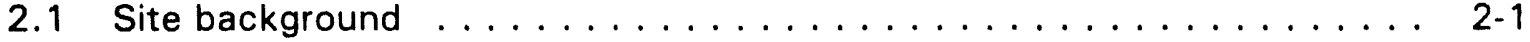

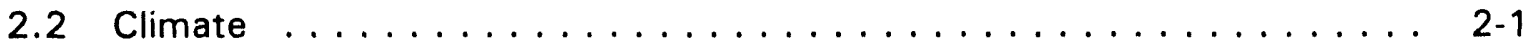

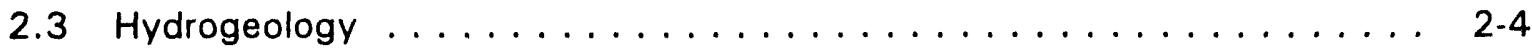

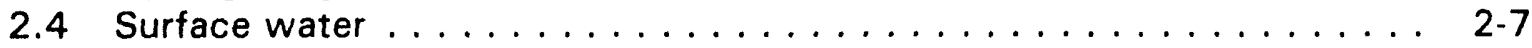

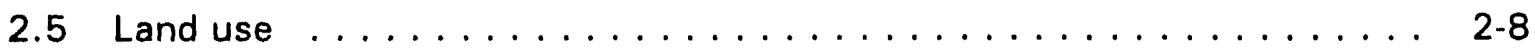

2.6 Water use ........................... 2.8

2.7 Previous risk assessment for groundwater use $\ldots \ldots \ldots \ldots \ldots \ldots$ 2-12

3.0 EXTENT OF CONTAMINATION $\ldots \ldots \ldots \ldots \ldots \ldots \ldots \ldots \ldots \ldots$

3.1 Background water quality data summary . . . . . . . . . . . 3-1

3.2 Magnitude and extent of site-related groundwater contamination ..... 3-1

3.3 Contaminants of concern .................... 3-8

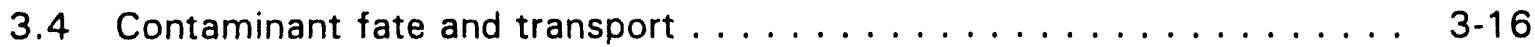

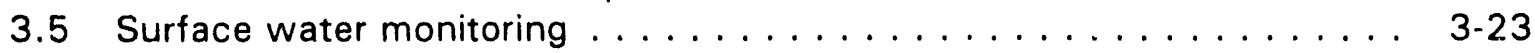

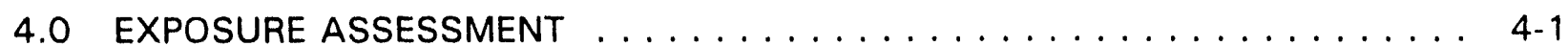

4.1 Potentially exposed population $\ldots \ldots \ldots \ldots \ldots \ldots \ldots \ldots \ldots$ 4-1

4.2 Exposure pathways ..................... 4-1

4.2.1 Drinking water ingestion ................... 4-1

4.2.2 Dermal absorption ....................... 4-3

4.2.3 Ingestion of groundwater-irrigated produce ... . . . . . . . 4-3

4.2.4 Ingestion of milk or meat from groundwater-fed livestock . . . . . 4-6

4.2 .5 Ingestion of fish . . . . . . . . . . . . . . . . . 4-6

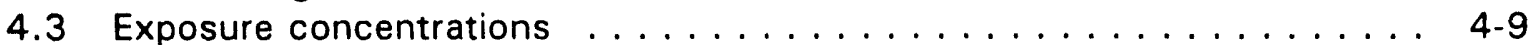

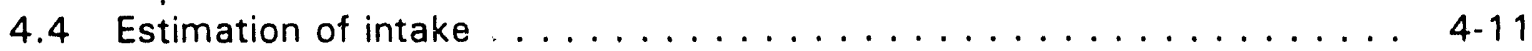

4.5 Exposure assessment uncertainties ................ 4-27

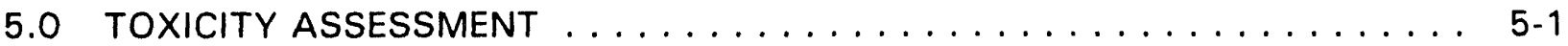

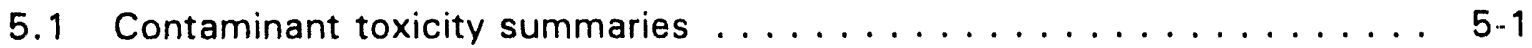

5.1 .1 Cadmium ...................... 5-1

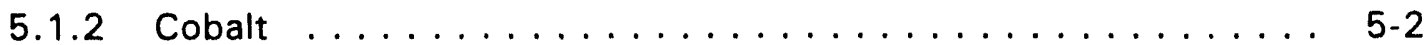

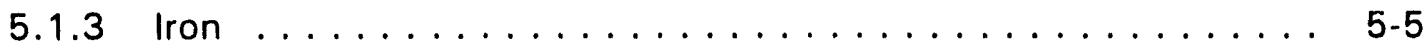

5.1 .4 Manganese ...................... 5-8

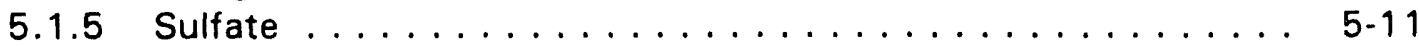

5.1 .6 Uranium ...................... 5-15

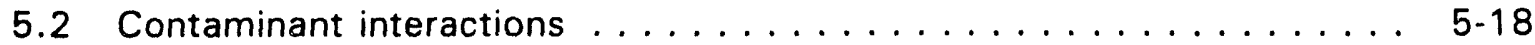

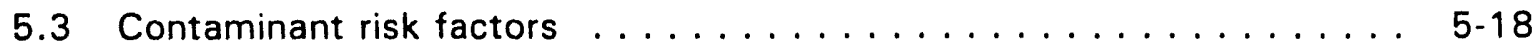




\section{TABLE OF CONTENTS (Concluded)}

Section

Page

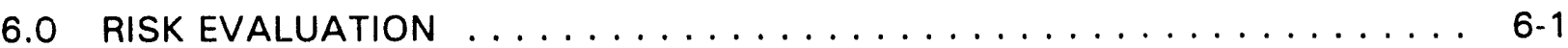

6.1 Potential noncarcinogenic health effects $\ldots \ldots \ldots \ldots \ldots \ldots \ldots \ldots$

6.2 Potential carcinogenic health effects . . . . . . . . . . . . 6 6-5

7.0 LIVESTOCK AND ENVIRONMENTAL EVALUATION $\ldots \ldots \ldots \ldots \ldots \ldots \ldots$

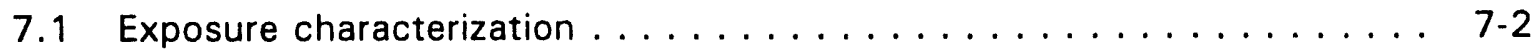

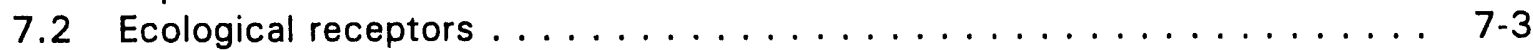

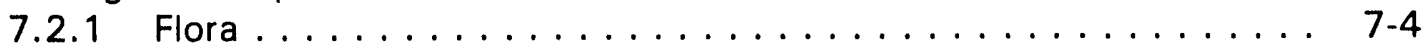

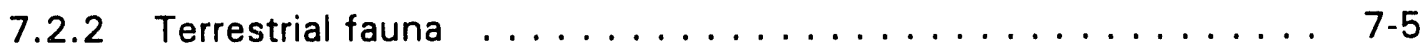

7.2 .3 Aquatic organisms ................... 7-6

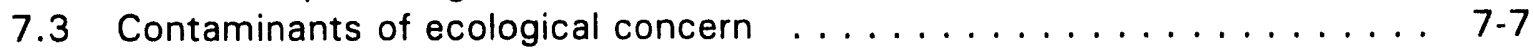

7.4 Potential impacts to wildlife and plants $\ldots \ldots \ldots \ldots \ldots \ldots \ldots \ldots \ldots$

7.4 .1 Terrestrial risk ....................... 7-8

7.4 .2 Aquatic risk ....................... $7-14$

7.5 Potential impacts to livestock .................. 7-20

7.6 Summary ......................... $7-21$

8.0 INTERPRETATION AND RECOMMENDATIONS $\ldots \ldots \ldots \ldots \ldots \ldots \ldots \ldots \ldots$

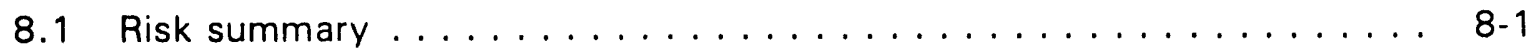

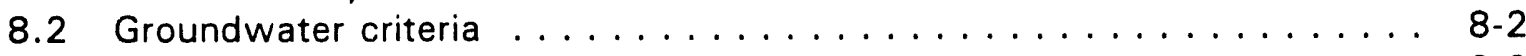

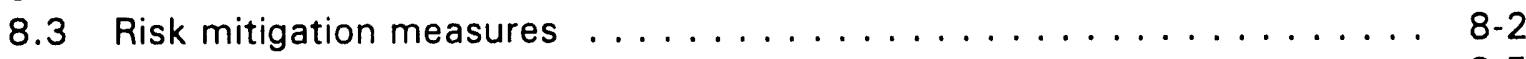

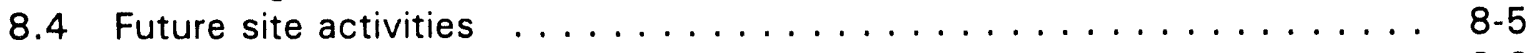

8.5 Recommendations . . . . . . . . . . . . . . . . . 8

9.0 LIST OF CONTRIBUTORS $\ldots \ldots \ldots \ldots \ldots \ldots \ldots \ldots \ldots \ldots \ldots$

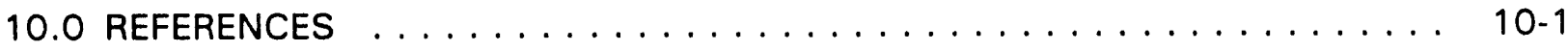




\section{LIST OF FIGURES}

Figure

2.1 Gunnison site location map, Colorado . . . . . . . . . . . . . . . . 2-2

2.2 Land use in the vicinity of the Gunnison processing site near Gunnison,

Colorado .................................. 2-3

2.3 Geologic cross section at the Gunnison processing site, Colorado . . . . . . . . 2. 2-5

2.4 Water table elevations in the alluvial aquifer, Gunnison processing site,

Gunnison, Colorado . . . . . . . . . . . . . . . . . . . . . . . . . . 2-6

2.5 Location of selected DOE monitor wells and domestic wells in the vicinity of

Gunnison processing site, Gunnison, Colorado . . . . . . . . . . . . . . . 2-9

2.6 Monitor well location map of the Gunnison processing site, Colorado . . . . . 2-10

2.7 Water supply system components near Gunnison, Colorado . . . . . . . . . 2-11

3.1 Approximate extent of sulfate contamination, Gunnison processing site,

Gunnison, Colorado ... . . . . . . . . . . . . . . . . . . . . . . . . 3-9

3.2 Approximate extent of uranium contamination, Gunnison processing site,

Gunnison, Colorado ............................... 3-10

3.3 Uranium concentrations vs. time in paired monitor wells 188 and 189,

Gunnison, Colorado, site ......................... 3-11

3.4 Uranium conce., irations vs. time in paired monitor wells 160 and 161 ,

Gunnison, Colorado, site ....................... 3-12

3.5 Iron concentrations vs. time in select downgradient monitor wells at the Gunnison, Colorado, site ... . . . . . . . . . . . . . . . . . .

3.6 Manganese concentrations vs. time in select downgradient monitor wells at the Gunnison, Colorado, site . . . . . . . . . . . . . . . . . .

3.7 $\mathrm{pH}$ vs. time in paired background monitor wells 001 and 101 , Gunnison,

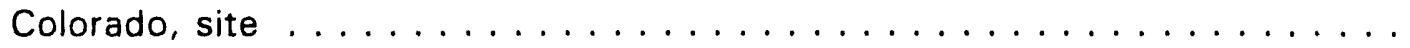

3.8 Alkalinity vs. time in paired background monitor wells 001 and 101, Gunnison, Colorado, site ...........................

3.9 Alkalinity vs. time in paired far downgradient monitor wells 188 and 189 , Gunnison, Colorado, site ........................

3.10 Iron concentrations vs. time for monitor wells 006, 007, and 009, Gunnison,

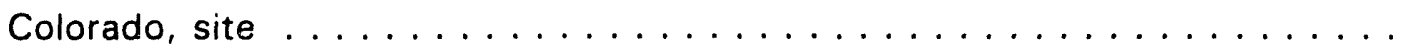

3.11 Surface water, sediment, and fish sampling locations in the vicinity of the Gunnison processing site, Gunnison, Colorado . . . . . . . . . . . . .

4.1 Gunnison conceptual model ........................

4.2 Simulated distribution of cadmium concentrations, Gunnison, Colorado, site . 4-12

4.3 Simulated distribution of cobalt concentrations, Gunnison, Colorado, site . . . 4-13

4.4 Simulated distribution of iron concentrations, Gunnison, Colorado, site . . . . 4-14

4.5 Simulated distribution of manganese concentrations, Gunnison, Colorado, site 4-15

4.6 Simulated distribution of sulfate concentrations, Gunnison, Colorado, site . . 4-16

4.7 Simulated distribution of uranium concentrations, Gunnison, Colorado, site . . 4-17

4.8 Probability distributions for tap water ingestion rates . . . . . . . . . . . 4-19

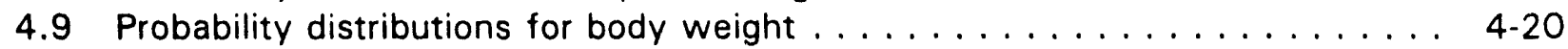




\section{LIST OF FIGURES (Concluded)}

Figure

4.10 Comparison of distributions of potential uranium exposures as a result of drinking contaminated groundwater for the three age groups examined, Gunnison, Colorado, site

4.11 Distribution of potential cadmium exposures for children as a result of groundwater ingestion, Gunnison, Colorado, site . . . . . . . . . . .

4.12 Distribution of potential cobalt exposures for children as a result of groundwater ingestion, Gunnison, Colorado, site . . . . . . . . . . . .

4.13 Distribution of potential iron exposures for children as a result of groundwater ingestion, Gunnison, Colorado, site ..................

4.14 Distribution of potential manganese exposures for children as a result of groundwater ingestion, Gunnison, Colorado, site . . . . . . . . . . . . .

4.15 Distribution of potential sulfate exposures for children as a result of groundwater ingestion, Gunnison, Colorado, site ...............

5.1 Cadmium toxicity ranges $\ldots \ldots \ldots \ldots \ldots \ldots \ldots \ldots \ldots \ldots \ldots \ldots$

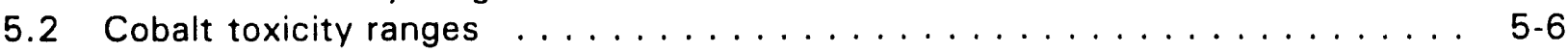

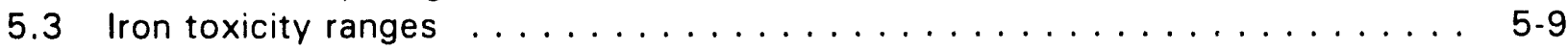

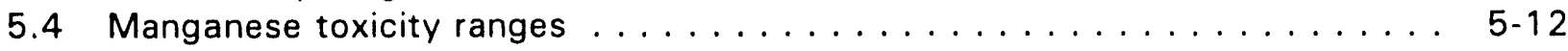

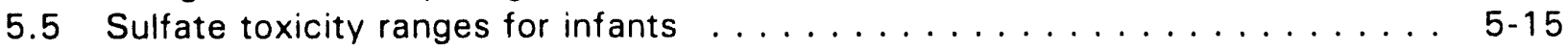

5.6 Half-lives and emissions from decay chain of uranium-238, Gunnison,

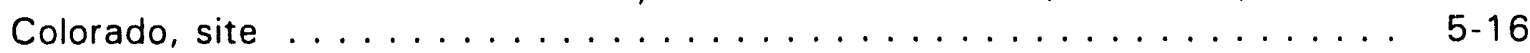

5.7 Uranium toxicity ranges $\ldots \ldots \ldots \ldots \ldots \ldots \ldots \ldots \ldots \ldots \ldots \ldots \ldots$

6.1 Health effects of potential iron exposure ranges for children . . . . . . . . 6 6-2

6.2 Health effects of potential manganese exposure ranges for children . . . . . . . 6-3

6.3 Health effects of potential sulfate exposure ranges for children . . . . . . . . 6. 6-4

6.4 Health effects of potential uranium exposure ranges for children . . . . . . . . 6.6 6

6.5 Health effects of potential cadmium exposure ranges for children . . . . . . . 6. 6-7

6.6 Health effects of potential cobalt exposure ranges for children . . . . . . . . 6-8 


\section{LIST OF TABLES}

Table

Page

3.1 Summary of filtered groundwater quality at Gunnison, Colorado . . . . . . . . . 3-2

3.2 Contaminants of potential concern for human health evaluation . . . . . . . 3-15

4.1 Exposure dose calculations and equation definitions for groundwater ingestion and dermal contact, Gunnison UMTRA Project site, Gunnison, Colorado . . . . 4.4

4.2 Exposure dose calculations and equation definitions for groundwater-irrigated garden produce ingestion, Gunnison UMTRA Project site, Gunnison, Colorado

4.3 Exposure dose calculations and equation definitions for ingestion of milk from groundwater-fed livestock, Gunnison UMTRA Project site, Gunnison, Colorado .

4.4 Exposure dose calculations and equation definitions for ingestion of meat from groundwater-fed livestock, Gunnison UMTRA Project site, Gunnison, Colorado.

4.5 Constituents in muscle tissue of fish collected from surface water bodies located in the site vicinity, Gunnison UMTRA Project site, Gunnison, Colorado.

4.6 Exposure dose calculations and equation definitions for ingestion of fish from surface water bodies in the site vicinity, Gunnison UMTRA Project site, Gunnison, Colorado . . . . . . . . . . . . . . . . . . . . . .

5.1 Toxicity values: potential noncarcinogenic effects $\ldots \ldots \ldots \ldots \ldots \ldots$ 5-21

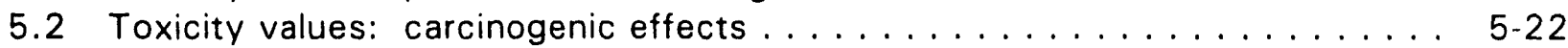

6.1 Excess lifetime cancer risk calculations for groundwater ingestion by a hypothetical future adult resident, Gunnison UMTRA Project site, Gunnison Colorado . . . . . . . . . . . . . . . . . . . . . . . . . . . . . .

7.1 Occurrence of constituents detected in surface water bodies located in the site vicinity, Gunnison UMTRA Project site, Gunnison, Colorado . . . . . . . . . . 7-8

7.2 Comparison of estimated plant concentrations to phytotoxic concentrations, Gunnison UMTRA Project site, Gunnison, Colorado . . . . . . . . . . . . . . 7-10

7.3 Comparison of contaminants of potential concern in groundwater with available water quality values, Gunnison UMTRA Project site, Gunnison, Colorado . . . . . . . . . . . . . . . . . . . . . . . . . . .

7.4 Comparison of contaminants of potential concern in surface water bodies located in the site vicinity with available water quality values, Gunnison UMTRA Project site, Gunnison, Colorado . . . . . . . . . . . . . . . . . . .

7.5 Comparison of contaminants of potential concern in sediment from surface water bodies located in the site vicinity with available sediment quality values, Gunnison UMTRA Project site, Gunnison, Colorado . . . . . . . . . . . . . . .

8.1 Concentration limits of constituents $\ldots \ldots \ldots \ldots \ldots \ldots \ldots$ 


\section{LIST OF ACRONYMS AND ABBREVIATIONS}

\section{Acronym}

ac

$A C L$

$B C F$

$\mathrm{CDH}$

$\mathrm{cm}$

$\mathrm{cm} / \mathrm{s}$

${ }^{\circ} \mathrm{C}$

${ }^{\circ} \mathrm{F}$

DOE

DW

EA

EPA

ER-L

ER-M

$\mathrm{ft}$

$\mathrm{ft} / \mathrm{yr}$

$\mathrm{ft}^{2} / \mathrm{day}$

$\mathrm{ft}^{3} / \mathrm{s}$

FWS

ha

HEAST

in

IRIS

$\mathrm{km}$

$\mathrm{km}^{2}$

$\mathrm{L}$

$\mathrm{L} / \mathrm{kg}$

LOAEL

$\mu \mathrm{g}$

$\mu \mathrm{g} / \mathrm{kg}$

$\mathrm{m}$

$\mathrm{m}^{2} / \mathrm{day}$

$\mathrm{m}^{3}$

$\mathrm{m}^{3} / \mathrm{s}$

$\mathrm{MCL}$

$\mathrm{mg}$

$\mathrm{mg} / \mathrm{kg} / \mathrm{day}$

$\mathrm{mg} / \mathrm{L}$

$\mathrm{mi}$

$m i^{2}$

NOAA

NOAEL

$\mathrm{pCi}$

\section{Definition}

acre

alternate concentration limit

bioconcentration factor

Colorado Department of Health

centimeter

centimeters per second

degrees Celsius

degrees Fahrenheit

U.S. Department of Energy

dry weight

environmental assessment

U.S. Environmental Protection Agency

effects range-low

effects range-median

foot

feet per year

square feet per day

cubic feet per second

Fish and Wildlife Service

hectare

Health Effects Assessment Summary Table

inch

Integrated Risk Information System

kilometer

square kilometer

liter

liters per kilogram

lowest-observed-adverse-effect level

microgram

micrograms per kilogram

meter

square meters per day

cubic meter

cubic meters per second

maximum concentration limit

milligram

milligrams per kilogram per day

milligrams per liter

mile

square mile

National Oceanic and Atmospheric Administration

no-observed-adverse-effect level

picocurie 


\section{LIST OF ACRONYMS AND ABBREVIATIONS (Concluded)}

\section{Acronym}

PEIS

PL

PNL

RAP

RDA

RfD

SF

SQC

$T \& E$

TDS

TR

UCL

UMTRA

UMTRCA

WSAP

$y d^{3}$

\section{Definition}

programmatic environmental impact statement

public law

Pacific Northwest Laboratory

remedial action plan

recommended daily allowance

reference dose

slope factor

sediment quality criteria

threatened and endangered

total dissolved solids

target risk

upper confidence limit

Uranium Mill Tailings Remedial Action

Uranium Mill Tailings Radiation Control Act

water sampling and analysis plan

cubic yard 


\subsection{INTRODUCTION}

The purpose of this baseline risk assessment is to determine whether the groundwater contamination at the Gunnison, Colorado, uranium mill tailings site has the potential to adversely affect public health or the environment. The Gunnison site is one of 24 abandoned uranium mill tailings sites that are undergoing remediation in accordance with the requirements of the Uranium Mill Tailings Radiation Control Act (UMTRCA) of 1978 [Public Law (PL) 95-604] under the oversight of the U.S. Department of Energy (DOE) Uranium Mill Tailings Remedial Action (UMTRA) Project.

Under the UMTRA Surface Project, the DOE is stabilizing tailings in disposal cells that minimize radon and other radiation emissions and further contamination of groundwater. At the Gunnison site, the tailings and other contaminated materials will be transported approximately 6 miles (mi) $[10$ kilometers $(\mathrm{km})]$ to the disposal cell for stabilization. Movement of the tailings is currently in progress and should be completed by September 1994.

Under the UMTRA Groundwater Project, groundwater contamination at the 24 sites will be evaluated to determine whether any remedial action is necessary and to implement such action. The DOE was authorized to perform groundwater restoration in the 1988 amendments to the UMTRCA.

The evaluation strategy and remediation methodology for contaminated groundwater at the UMTRA sites are described in the Programmatic Environmental Impact Statement for the Uranium Mill Tailings Remedial Action Ground Water Project (DOE, 1993). This baseline risk assessment is one of the site-specific documents prepared to evaluate potential health and environmental risks and provide information to assist in determining what remedial action is necessary. Based on the programmatic environmental impact statement (PEIS), additional groundwater characterization, and this risk assessment, a site-specific environmental assessment will be prepared to evaluate and select a remedial action for the Gunnison site.

A preliminary baseline risk assessment was conducted in 1990 (DOE, 1990) to determine whether long-term use of groundwater from domestic wells near the site has a potential to adversely affect public health. This second assessment of groundwater-related risks is based on currently available groundwater data from the most contaminated wells at the processing site and includes an evaluation of pathways associated with surface water, sediment, and fish tissue. These data from the surface water bodies were not available for the first assessment of groundwater-related risks (DOE, 1990). Where data are not sufficient to adequately evaluate risks at this time, these data gaps will be identified. This document will be updated following completion of the site characterization phase of the Groundwater Project. If future decisions or actions at this site alter the contribution from the primary pathways evaluated here, minor pathways not considered here will be evaluated in more detail in future documents.

This risk assessment follows the basic approach prescribed by the U.S. Environmental Protection Agency (EPA) for evaluating hazardous waste sites for potential health and 
environmental impacts resulting from groundwater contamination at the Gunnison site.

The baseline risk assessment includes the following steps:

- Data evaluation.

- Combining existing data from various site investigations.

- Comparing sample results with background and tailings source data.

- Selecting chemical data for use in the risk assessment.

- Exposure assessment.

- Characterizing exposure setting.

- Identifying exposure pathways.

- Quantifying exposure.

- Toxicity assessment.

- Identifying toxicity values.

- Evaluating noncarcinogenic effects.

- Evaluating carcinogenic effects from radionuclides and chemical carcinogens.

- Public health risk characterization.

- Comparing toxicity ranges to predicted exposure ranges.

- Combining risks across exposure pathways and multiple contaminants.

- Characterizing uncertainties.

- Environmental risk.

- Characterizing potential biota exposure pathways.

- Identifying potential ecological receptors.

- Evaluating environmental risk qualitatively.

These steps are used to estimate risks from potential current and future use of groundwater and surface water. 


\subsection{SITE DESCRIPTION}

\subsection{SITE BACKGROUND}

The processing site is located adjacent to the city of Gunnison in Gunnison County, Colorado, between the Gunnison River and Tomichi Creek (Figure 2.1). The mill was constructed in the late 1950 s to produce uranium to sell to the U.S. Atomic Energy Commission (predecessor to the DOE) and was operated from February 1958 until April 1962. Ore was trucked to the mill from mines in the Cochetopa Pass area, about $25 \mathrm{mi}(40 \mathrm{~km})$ southeast of Gunnison. The ore was ground and then leached with sulfuric acid and sodium chlorate. After leaching, the uraniumrich solutions and waste solids were separated by a four-stage countercurrent classifier and thickener circuit. The uranium solutions were then treated by solvent extraction to concentrate and recover the uranium; the solids were dumped in what became the tailings pile. During its 4 years of operation, the mill processed about 540,000 dry tons $(490,000$ metric tons) of ore with an average grade of 0.15 percent uranium oxide (FBDU, 1981).

The designated site covers 61 acres (ac) [24 hectares (ha)]; approximately 35 ac (14 ha) are occupied by the rectangularly shaped tailings pile and approximately 20 more ac ( $8 \mathrm{ha}$ ) were occupied by the former mill structures, the former ore storage area, and miscellaneous areas (Figure 2.2). Windblown contaminated areas within and adjacent to the designated site occupy an additional $17 \mathrm{ac}(6.8 \mathrm{ha})$.

Uranium mill tailings, contaminated vicinity property materials, demolition debris (which has been stored on the site), and windblown materials are being relocated to a permanent disposal site during 1993 and 1994. This disposal site was selected based on public input, environmental considerations, and design opportunities acceptable to the regulatory agencies involved. The selected site is approximately $6 \mathrm{mi}(10 \mathrm{~km})$ east of the town of Gunnison and 0.4 mile $(0.6 \mathrm{~km})$ south of the county solid waste landfill.

\subsection{CLIMATE}

The Gunnison area is characterized by low humidity, frequent sunny days, and large daily and seasonal temperature ranges. The average annual temperature is 37 degrees Fahrenheit $\left({ }^{\circ} \mathrm{F}\right)\left[2.8\right.$ degrees Celsius $\left.\left({ }^{\circ} \mathrm{C}\right)\right]$ and ranges from an average temperature of $10^{\circ} \mathrm{F}\left(-12^{\circ} \mathrm{C}\right)$ in January to $62^{\circ} \mathrm{F}\left(17^{\circ} \mathrm{C}\right)$ in July. The average annual precipitation is 11 inches (in) [28 centimeters $(\mathrm{cm})]$. Maximum rainfall occurs during July and August, while the least rainfall occurs from April through June. Thunderstorms are common during the summer. The average annual snowfall accumulation is 58 in $(150 \mathrm{~cm})$, with the largest amount falling during the month of January (NOAA, 1984). 


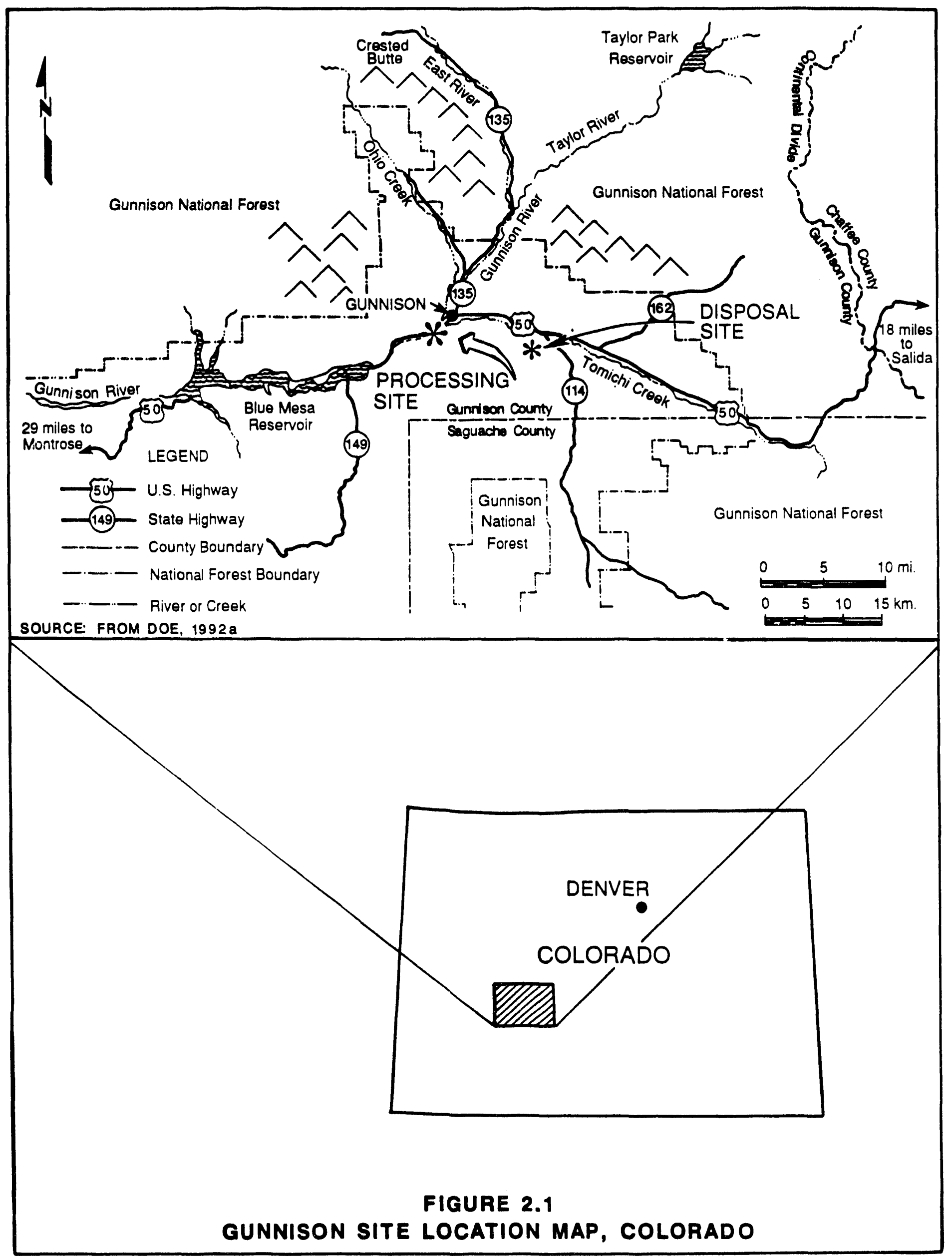




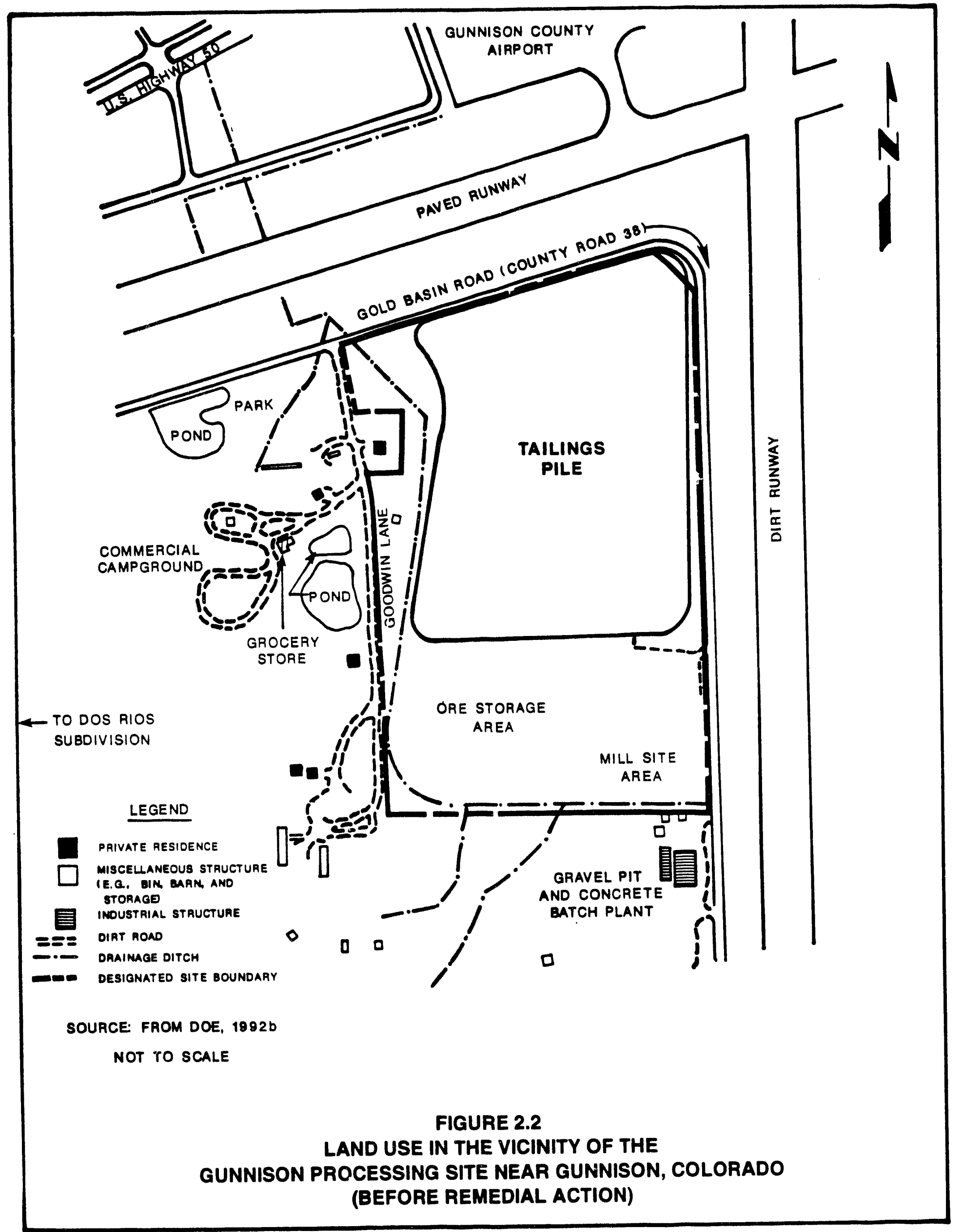




\subsection{HYDROGEOLOGY}

Widespread recent floodplain and terrace deposits (hereafter referred to as alluvium) associated with the Gunnison River and Tomichi Creek underlie the Gunnison processing site and surrounding vicinity. The alluvium is composed of poorly sorted material ranging in size from clay-sized material to cobbles and occasional boulders. The alluvium generally tends to become more clayey with depth. A cross-sectional view of the subsurface materials is provided in Figure 2.3. The thickness of the alluvium is extensive, ranging from $72 \mathrm{ft}(22 \mathrm{~m})$ to greater than $130 \mathrm{ft}(40 \mathrm{~m})$. The alluvium extends beyond the bottom of most of the boreholes and wells drilled ty the DOE. Underlying the alluvium is a discontinuous unit of unknown extent and thickness, known as the Brushy Basin Member of the Morrison Formation. Because the Brushy Basin Member is not a significant water-bearing formation (DOE, $1992 a$ ), it is not discussed further.

During previous site characterization activities, the DOE has placed monitor well clusters upgradient and downgradient of the Gunnison processing site. These monitor well clusters generally consist of a shallow well (approximately 10 to $25 \mathrm{ft}$ [ 3 to $8 \mathrm{~m}$ ] deep below land surface), an intermediate well (approximately 40 to $60 \mathrm{ft}[12$ to $18 \mathrm{~m}$ ] deep below land surface), and a deep well (approximately 90 to $100 \mathrm{ft}[27$ to $30 \mathrm{~m}$ ] deep below land surface). The bottom $5 \mathrm{ft}(1.5 \mathrm{~m})$ of each well is screened. Static water level elevations measured in the shallow monitor wells are displayed in Figure 2.4. This water table contour map shows that shallow groundwater flows to the southwest as a subdued topographic replica of the land surface. The direction of horizontal groundwater movement is comparable in the intermediate and deep monitor wells. The alluvial aquifer is generally unconfined. However, low hydraulic conductivity silt and clay may create semiconfined conditions with increasing depth in the alluvium. Static water levels in each well of the monitor well clusters generally indicate a slight downward vertical gradient. However, since groundwater elevations in the alluvium fluctuate seasonally at the site, these downward vertical gradients may reverse locally in accordance with changes in recharge and discharge. The seasonal high water table usually occurs in early summer, and the seasonal low water table usually occurs in late winter.

The alluvial aquifer receives recharge from precipitation, snowmelt, and seasonally from the Gunnison River and Tomichi Creek. In addition, seasonal recharge occurs from the irrigation ditches around the site. Groundwater discharge is expected to occur as a result of localized pumping, shallow baseflow to the Gunnison River and/or Tomichi Creek, and deep groundwater underflow that follows the southwest course of the Gunnison River downgradient of the Dos Rios subdivision.

Hydraulic properties at the Gunnison processing site have been estimated and presented in the remedial action plan (RAP) (DOE, 1992a). A 48-hour constant discharge pumping test was performed in October 1983 in an 8 -in $(20-\mathrm{cm})$ diameter well completed in the alluvial aquifer to a total depth of $50 \mathrm{ft}(15 \mathrm{~m})$. The results were analyzed using the Theis type curve fitting method and the Jacob-Cooper Approximation and are presented in Appendix $C$ to Attachment 3 of the Gunnison RAP (DOE, 1992a). The calculated range of transmissivity for the alluvial aquifer 


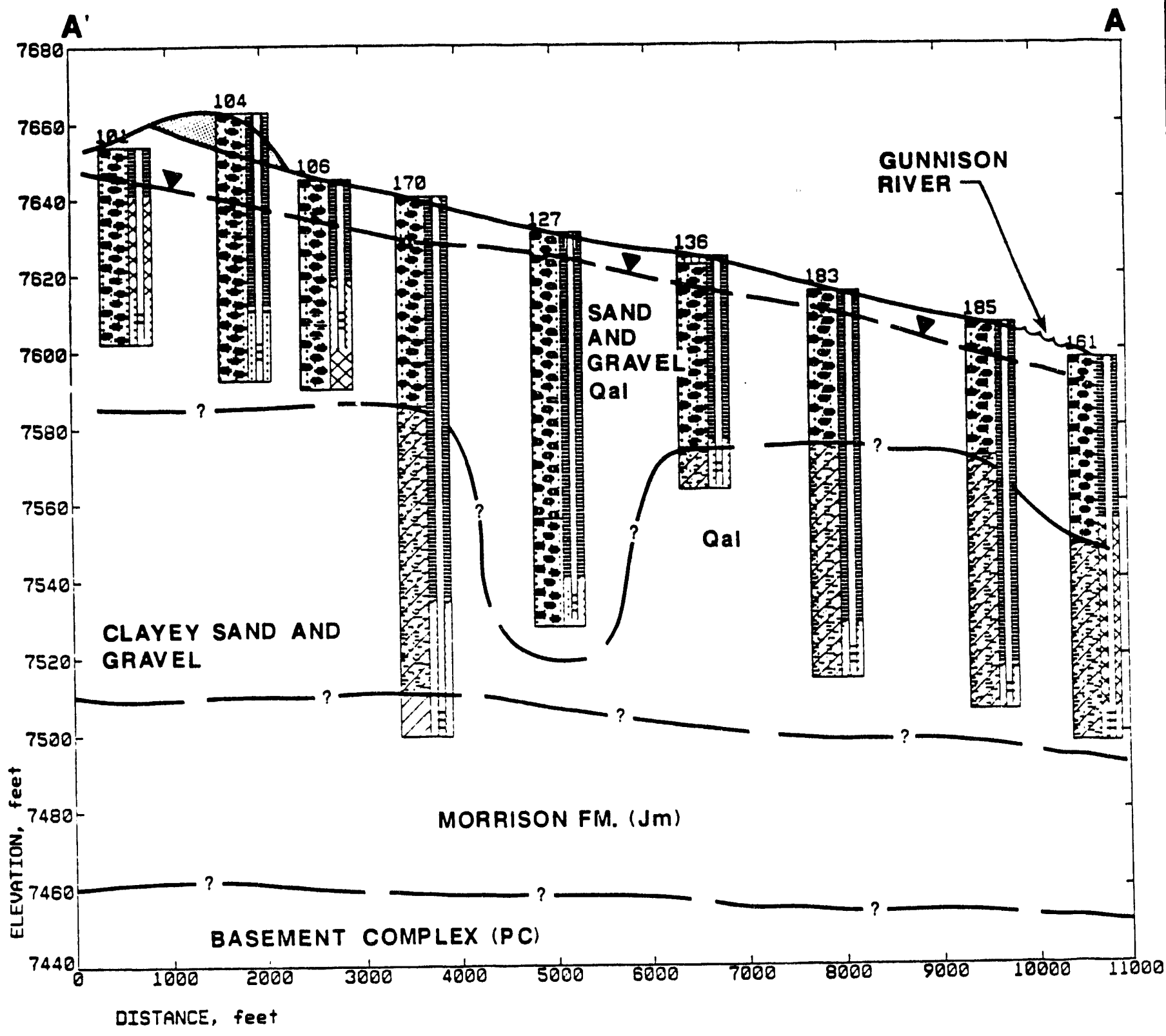

\section{LEGEND}

Qal QUATERNARY ALLUVIUM

Jm JURASSIC MORRISON FORMATION

PE PRE-CAMBRIAN BASEMENT COMPLEX

-Z WATER TABLE, WATER LEVEL ELV. MEAS. IN FEBRUARY 1991

TAILINGS PILE

NOTE: SEE FIGURE 2.5 FOR CROSS SECTION LOCATION

SOURCE: FROM DOE, $1992 \mathrm{a}$

FIGURE 2.3

GEOLOGIC CROSS SECTION AT

THE GUNNISON PROCESSING SITE, COLORADO 


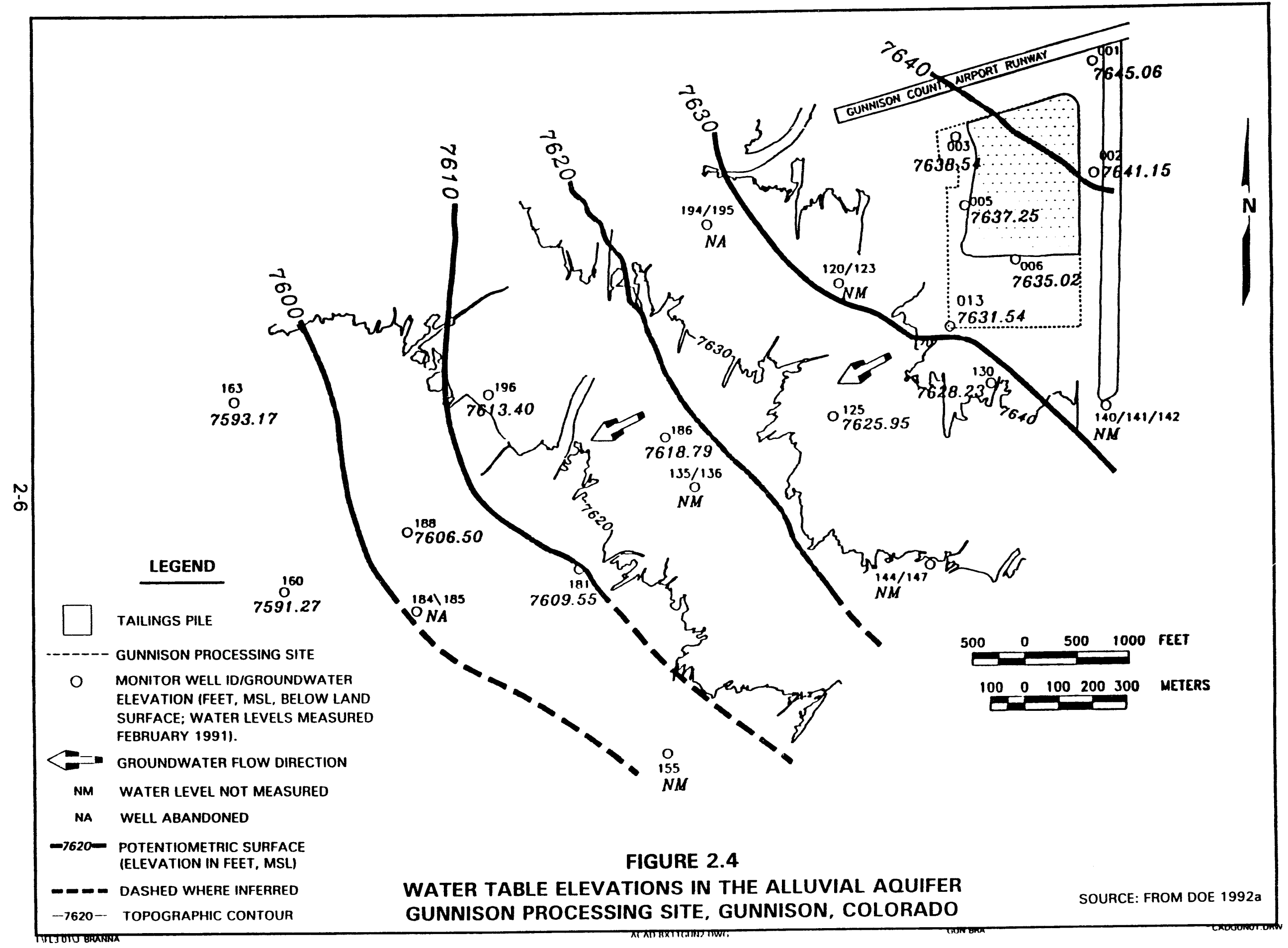


varies from 420 to 9600 square feet per day ( $\mathrm{ft}^{2} / \mathrm{day}$ ) [ 39 to 890 square meters per day $\left(\mathrm{m}^{2} /\right.$ day) $]$. Hydraulic conductivities were calculated by dividing the transmissivity for each observation well by the saturated thickness of the pumping well $[(40.5 \mathrm{ft}(12.3 \mathrm{~m})]$. Hydraulic conductivities range from $10 \mathrm{tc}<40 \mathrm{ft} / \mathrm{day}$ $[0.0035$ to 0.084 centimeters per second $(\mathrm{cm} / \mathrm{s})]$. The wide range of hydraulic conductivity values results from the variation in size of the poorly sorted subsurface material, from clay to gravels and cobbles with occasional boulders.

Storage coefficient values range from $7 \times 10^{-4}$ to $3 \times 10^{-3}$. The calculated horizontal hydraulic gradient ranges from $3.8 \times 10^{-3}$ to $4.8 \times 10^{-3}$ (DOE, 1992a). The average linear groundwater velocity was calculated by applying Darcy's Law using the geometric mean hydraulic conductivity $[44 \mathrm{ft} /$ day $(0.02 \mathrm{~cm} / \mathrm{s})]$, water table gradient $\left(4.23 \times 10^{-3}\right)$, and porosity value $(0.25$ for gravelly alluvium) appropriate for the site (Freeze and Cherry, 1979; Davis and DeWeist, 1966). From this calculation, the average groundwater velocity in the alluvial aquifer is estimated to be $270 \mathrm{ft} / \mathrm{yr}\left(4.3 \times 10^{-4} \mathrm{~cm} / \mathrm{s}\right)(D O E, 1992 \mathrm{a})$. Although groundwater velocity is subject to localized variations from heterogeneities in the subsurface materials, this calculated average value appears to be representative of the alluvial groundwater system, based on the distance of migration of the contaminant plume relative to the duration of time that the tailings have been placed on-site. Assuming that groundwater moves at an approximate rate of $270 \mathrm{ft} / \mathrm{yr}$, and that the tailings have been in place at the processing site for approximately 30 years, the leading edge of the contaminant plume should be expected to have moved roughly $8100 \mathrm{ft}$ $(2500 \mathrm{~m})$ downgradient from the tailings pile. Based on actual water quality data for conservative (mobile) species (uranium and sulfate), the estimated groundwater velocity value appears to be representative. The magnitude and extent of siterelated contamination are discussed in detail in Section 3.2.

\subsection{SURFACE WATER}

The Gunnison processing site lies in the Gunnison River basin, $0.4 \mathrm{mi}(0.6 \mathrm{~km})$ east of the Gunnison River, $0.4 \mathrm{mi}(0.6 \mathrm{~km})$ northwest of Tomichi Creek, and $1.5 \mathrm{mi}$ $(2.4 \mathrm{~km})$ above the confluence of the two. Drainage across the site is to the south and east toward Tomichi Creek. The site is bounded on the west by small storm drainage ditches and on the south and west by an irrigation ditch. Some sections of the irrigation ditch will be relocated during site restoration.

The Gunnison River has a drainage basin of 1012 square miles $\left(\mathrm{mi}^{2}\right.$ ) [2621 square kilometers $\left.\left(\mathrm{km}^{2}\right)\right]$ above its confluence with Tomichi Creek. The USGS reports an average flow of about 700 cubic feet per second $\mathrm{ft}^{3} / \mathrm{s}$ [ 20 cubic meters per second $\left(\mathrm{m}^{3} / \mathrm{s}\right)$ ] (USGS, 1984). The maximum recorded flow of the Gunnison River for the 55 years of record was $11,450 \mathrm{ft}^{3} / \mathrm{s}\left(324 \mathrm{~m}^{3} / \mathrm{s}\right)$ in 1918 (USGS, 1984).

Tomichi Creek has a drainage basin of $1061 \mathrm{mi}^{2}\left(2748 \mathrm{~km}^{2}\right)$ above its confluence with the Gunnison River and has an average annual flow of about $160 \mathrm{ft}^{3} / \mathrm{s}$ $\left(5 \mathrm{~m}^{3} / \mathrm{s}\right)$. A maximum flow of $1890 \mathrm{ft}^{3} / \mathrm{s}\left(54 \mathrm{~m}^{3} / \mathrm{s}\right)$ was recorded in 1957 (USGS, 1984). 
Snow generally melts from May through June in the Gunnison area. Based on recorded flow data, maximum flows occur in the Gunnison River Basin during the spring runoff. Runoff from snowmelt is occasionally augmented by rainstorms; however, precipitation in the spring is generally the lowest of the year (USGS, 1984).

\subsection{LAND USE}

The former uranium processing site is adjacent to the city limits of Gunnison and the Gunnison County Airport. The main paved airport runway is within 200 feet (ft) [60 meters $(\mathrm{m})$ ] of the northern processing site boundary, and an einergency dirt runway is within $150 \mathrm{ft}(46 \mathrm{~m})$ of the eastern site boundary. On the north and east the site is bounded by former County Road 38 (Gold Basin Road), which has been rerouted as part of the tailings removal process. The land between this county road and the runways is owned by the county for expansion of the airport. The processing site has been acquired by the state of Colorado. An operating commercial gravel pit and concrete batch plant are on private land immediately south of the site. On private land west of the site are a park, a commercial campground with a grocery store and shower house, a small pond that is used for fishing, and five private residences (DOE, 1990). There are more than 100 private domestic wells within a mile and downgradient of the site, between the Gunnison River and Tomichi Creek.

\subsection{WATER USE}

The well locations of residences along the western boundary of the Gunnison site are depicted in Figure 2.5. Figure 2.5 also shows the locations of DOE monitor wells downgradient of the site. The locations of monitor wells at the processing site are shown in Figure 2.6. Five private residences and a campground are located along Goodwin Lane. All of these houses and the campground obtain water from shallow wells completed in the alluvial aquifer but currently have the option of receiving bottled water as an interim measure. They will be connected to the alternate water supply when it is completed in 1994 (Figure 2.7).

Approximately $2000 \mathrm{ft}(600 \mathrm{~m})$ downgradient to the west and southwest of the site are Units 1 and 3 of the Dos Rios subdivision. The Dos Rios subdivision contains approximately 100 houses and a condominium complex east of the Gunnison River, most of which were built in the early 1970s. All of the houses obtain water from private wells completed in the alluvial aquifer. The closest domestic well in the subdivision lies approximately $1600 \mathrm{ft}(490 \mathrm{~m})$ from the processing site. The results of domestic water well sampling during July and October 1990 showed that 22 domestic water wells downgradient of the processing site had uranium concentrations that were elevated above background levels (DOE, 1992a). All residences that are potentially affected by groundwater contamination from the processing site are also currently being provided the option of receiving bottled water as an interim measure and will be connected to the 


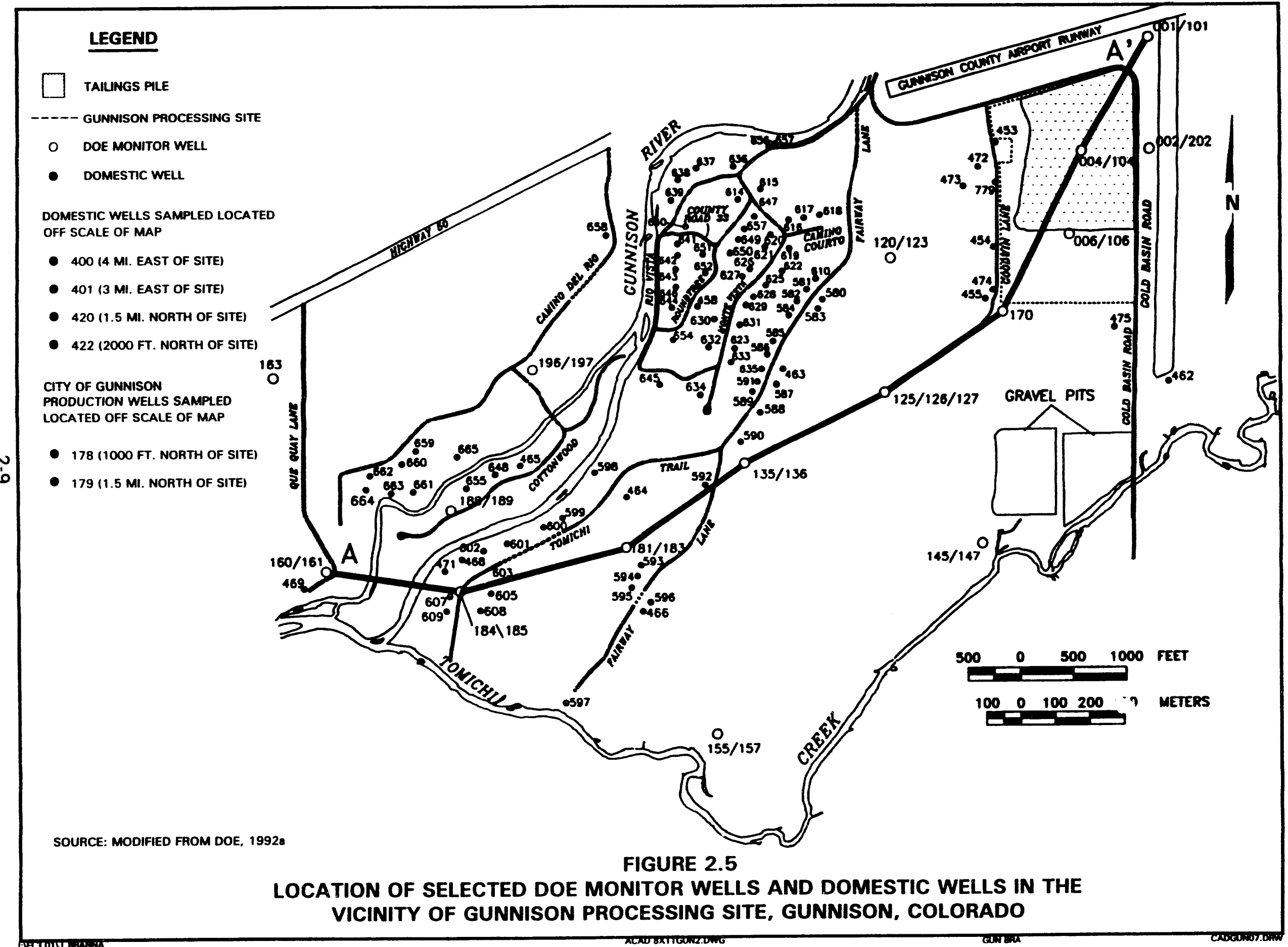




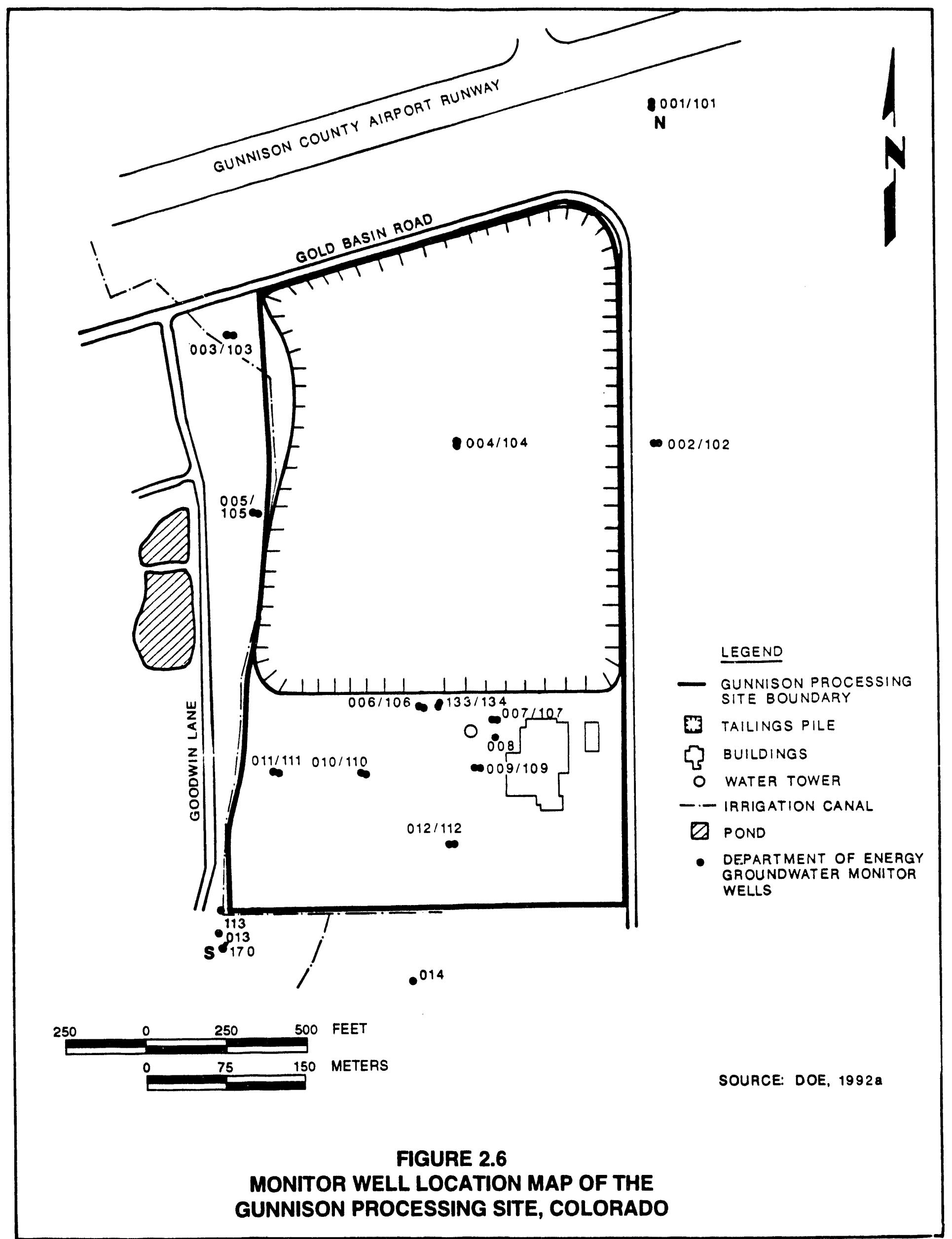




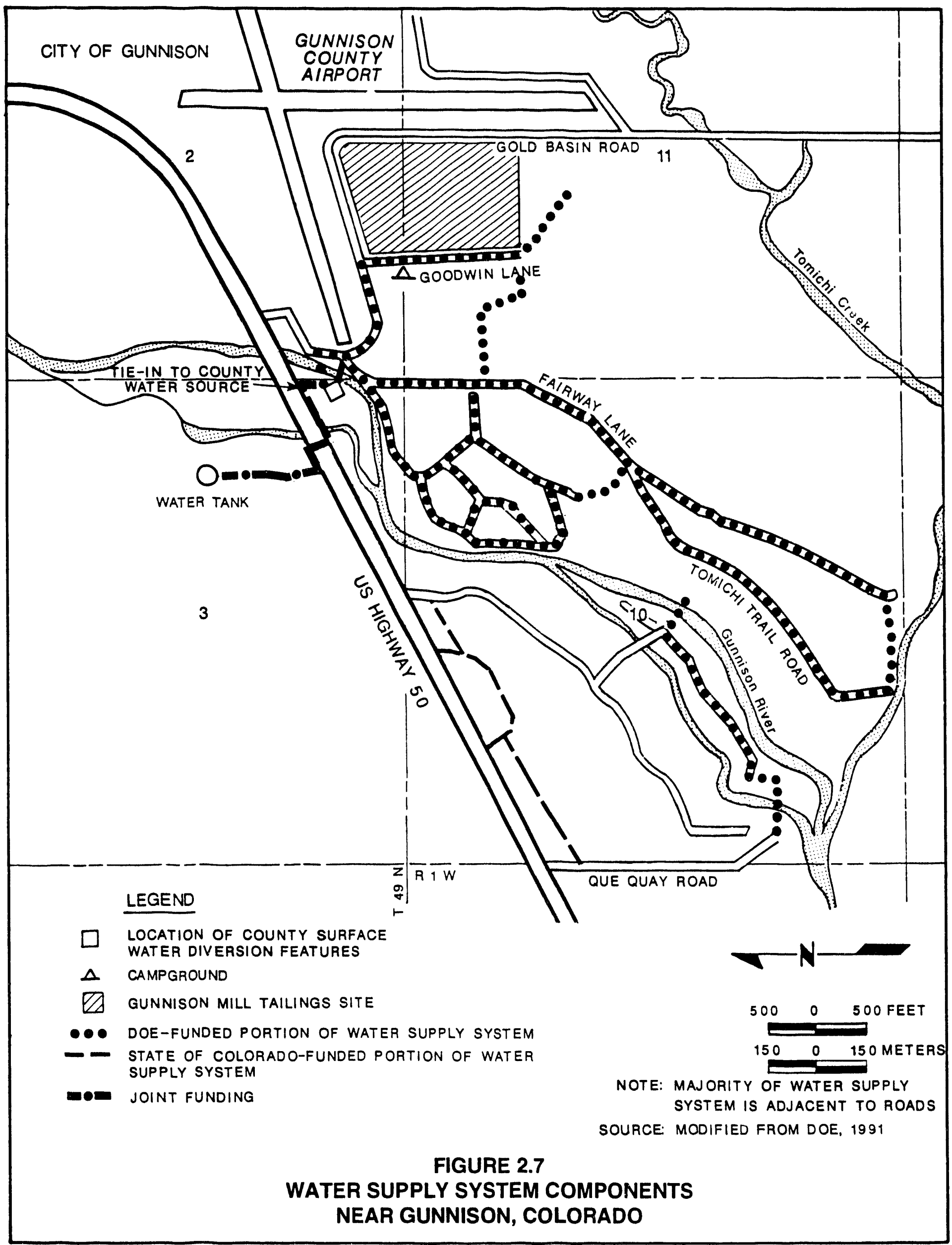


alternate water supply when it is completed (Figure 2.7). Groundwater monitoring will continue in the Dos Rios subdivision as a protective measure.

Adjoining the Gunnison site to the south is a gravel plant. This plant has an alluvial well used for its office in addition to a batch plant well used to make concrete. The owners have been provided the option of receiving bottled water.

The airport runways border the site to the north and east. The airport building is approximately $0.5 \mathrm{mi}(0.8 \mathrm{~km})$ from the site, upgradient and on the distant side of the runways. Therefore, the airport is not considered a potential receptor.

The city of Gunnison derives its entire municipal water supply from wells completed in the alluvial aquifer. All of the city's wells are north and upgradient of the site and are not affected by contaminants leaching from the tailings pile.

\subsection{PREVIOUS RISK ASSESSMENT FOR GROUNDWATER USE}

A preliminary baseline risk assessment was conducted during 1990 to determine whether long-term use of groundwater from domestic wells near the Gunnison processing site had the potential for adverse health effects (DOE, 1990). The results of domestic water well sampling for this baseline risk assessment during July and October of 1990 showed that 22 domestic water wells downgradient of the processing site had elevated levels of uranium that exceeded background levels [currently estimated to be 0.008 to 0.010 milligrams per liter (mg/L)], which are the maximum observed natural concentrations in the local area. Several of these wells also exceeded the proposed EPA health advisory level for uranium of $0.030 \mathrm{mg} / \mathrm{L}$ or the proposed maximum concentration limit in Table A of 40 CFR 192 of 0.044 $\mathrm{mg} / \mathrm{L}$. Other metals, including manganese, cadmium, and the uranium decay product lead-210, were also detected at levels significantly above background.

In September 1990, based on the results of the Gunnison preliminary baseline risk assessment for groundwater contamination (DOE, 1990), the DOE began making bottled water available to all downgradient users, including the entire Dos Rios subdivision, as a public health measure. The bottled water was intended to provide an interim action to those residents with contaminated water wells and to allow time for an evaluation of a permanent solution. The DOE evaluated ways of providing a permanent potable water supply system in an environmental assessment (EA) (DOE, 1991), which was approved in 1992. The DOE construction of a water supply system began in 1992 and is expected to be completed in 1994. 


\subsection{EXTENT OF CONTAMINATION}

A map of the Gunnison processing site showing the locations of the tailings pile and the pre-remediation DOE monitor well network is presented in Figure 2.6. All available DOE monitor well water quality data between 1985 and 1993 were used to characterize the plume geometry and the geochemical processes active at this site. Upgradient DOE monitor wells 001, 101; domestic wells 400,401,402, 422; and city wells 178 and 179 were used to define the background water quality of the alluvial aquifer at the Gunnison processing site. The locations of these background wells are given in Figure 2.5. Water quality data for the years 1989 through 1993 from the background DOE monitor wells were used in the statistical characterization of background. All available water quality data from the six non-DOE background wells (primarily collected between 1980 and 1990) were also used in this analysis. The background water quality, magnitude of contamination, plume geometry, and contaminants of concern for the Gunnison processing site are discussed below.

\subsection{BACKGROUND WATER QUALITY DATA SUMMARY}

The total dissolved solids (TDS) in the background groundwater samples range from $196 \mathrm{mg} / \mathrm{L}$ to $428 \mathrm{mg} / \mathrm{L}$, with a median value of $300 \mathrm{mg} / \mathrm{L}$. Sulfate concentrations range from $11 \mathrm{mg} / \mathrm{L}$ to $38 \mathrm{mg} / \mathrm{L}$, and alkalinity concentrations (expressed as $\mathrm{CaCO}_{3}$ ) range from $130 \mathrm{mg} / \mathrm{L}$ to $300 \mathrm{mg} / \mathrm{L}$, with median values of $18 \mathrm{mg} / \mathrm{L}$ and $236 \mathrm{mg} / \mathrm{L}$, respectively.

Uranium was present at low levels in all the background groundwater samples, with a maximum observed value of $0.0085 \mathrm{mg} / \mathrm{L}$. The dominant cationic species is calcium, with concentrations that range up to $102 \mathrm{mg} / \mathrm{L}$. The iron concentration in background groundwater ranged from $<0.03 \mathrm{mg} / \mathrm{L}$ to $2.7 \mathrm{mg} / \mathrm{L}$, with a median of $0.28 \mathrm{mg} / \mathrm{L}$. The high value for iron $(2.7 \mathrm{mg} / \mathrm{L})$ was significantly higher than other background iron values taken from these wells (median value $=0.28 \mathrm{mg} / \mathrm{L}$ ). This single high iron value may represent a sampling $c$ : analysis anomaly. Manganese values ranged from $<0.01 \mathrm{mg} / \mathrm{L}$ to $0.81 \mathrm{mg} . \mathrm{L}$, with a median value of $0.06 \mathrm{mg} / \mathrm{L}$. Although the upgradient background groundwater samples were typically low in manganese and iron, there is some evidence that naturally elevated iron and manganese levels may have been present in some monitor wells that are downgradient of the Gunnison tailings. This is discussed in greater detail in Section 3.2. Table 3.1 summarizes the minimum, median, and maximum values found for 42 chemical parameters in background groundwater and plume-affected groundwater for the Gunnison processing site.

\subsection{MAGNITUDE AND EXTENT OF SITE-RELATED GROUNDWATER CONTAMINATION}

Groundwater at the Gunnison processing site has been contaminated by acidic tailings leachate that contains high concentrations of uranium, iron, manganese, and sulfate, as well as many other constituents (Table 3.1). As discussed above, 


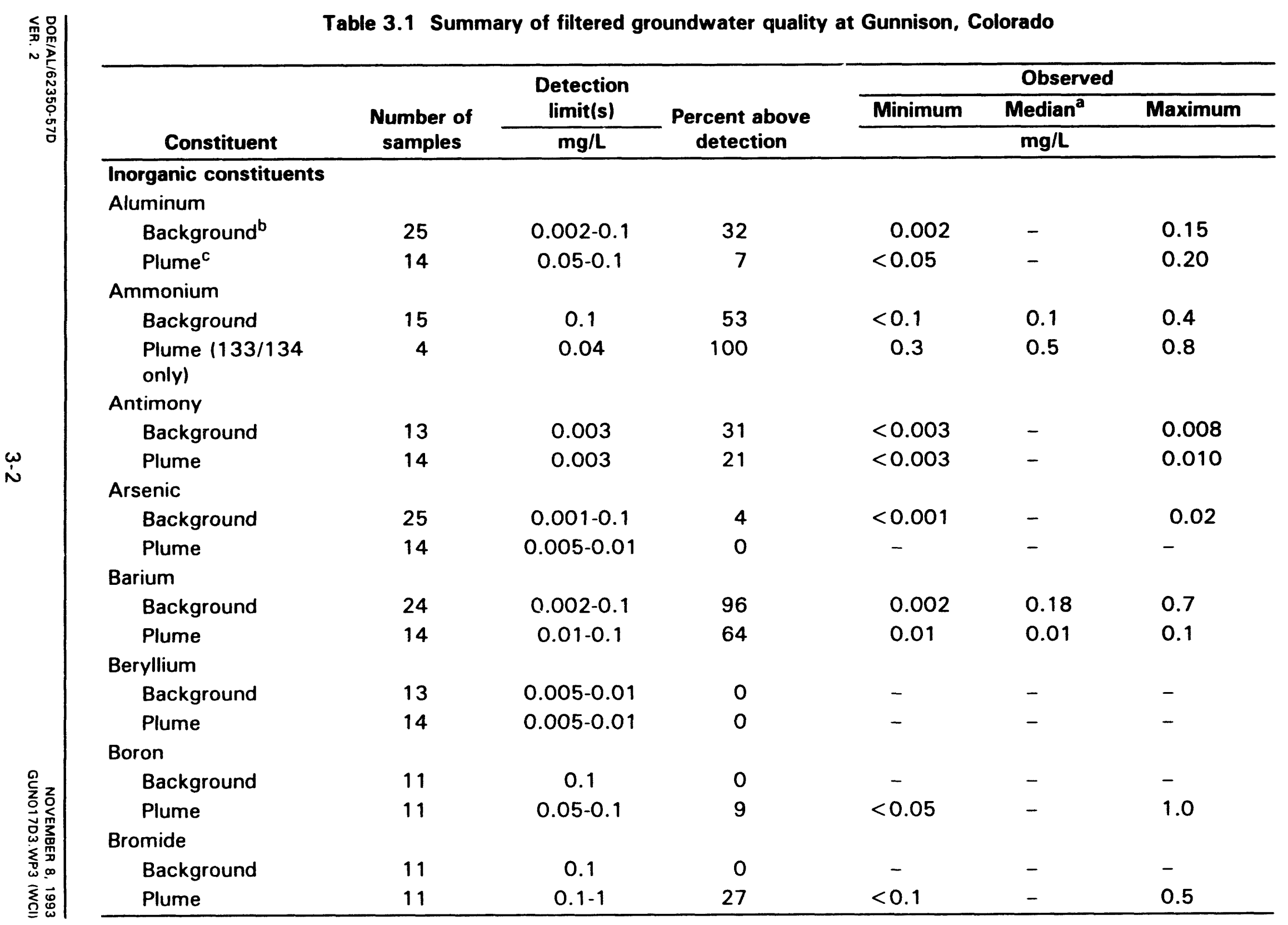




\begin{tabular}{|c|c|c|c|c|c|c|}
\hline \multirow[b]{3}{*}{ Constituent } & \multirow{3}{*}{$\begin{array}{c}\text { Number of } \\
\text { samples }\end{array}$} & \multirow{3}{*}{$\begin{array}{c}\begin{array}{c}\text { Detection } \\
\text { limit(s) }\end{array} \\
\mathrm{mg} / \mathrm{L} \\
\end{array}$} & \multirow{3}{*}{$\begin{array}{c}\text { Percent above } \\
\text { detection }\end{array}$} & \multicolumn{3}{|c|}{ Observed } \\
\hline & & & & Minimum & Median $^{2}$ & Maximum \\
\hline & & & & & $\mathrm{mg} / \mathrm{L}$ & \\
\hline \multicolumn{7}{|l|}{ Cadmium } \\
\hline Background ${ }^{b}$ & 24 & $0.0001-0.005$ & 0 & - & - & - \\
\hline Plume $^{c}$ & 14 & $0.0001-0.001$ & 71 & $<0.001$ & 0.001 & 0.004 \\
\hline \multicolumn{7}{|l|}{ Calcium } \\
\hline Background & 27 & $0.001-0.01$ & 100 & 35 & 75 & 102 \\
\hline Plume & 15 & $0.01-2$ & 100 & 92 & 650 & 690 \\
\hline \multicolumn{7}{|l|}{ Chloride } \\
\hline Background & 27 & $0.2-1$ & 100 & 2 & 14 & 31 \\
\hline Plume & 15 & $0.5-1$ & 100 & 10 & 15 & 20 \\
\hline \multicolumn{7}{|l|}{ Chromium } \\
\hline Background & 24 & $0.001-0.01$ & 0 & - & - & - \\
\hline Plume & 14 & $0.01-0.05$ & 0 & - & - & - \\
\hline \multicolumn{7}{|l|}{ Cobalt } \\
\hline Background & 13 & $0.03-0.05$ & 0 & - & - & - \\
\hline $\begin{array}{l}\text { Plume }(133 / 134 \\
\text { only) }\end{array}$ & 4 & $0.03-0.05$ & 100 & 0.19 & 0.32 & 0.37 \\
\hline \multicolumn{7}{|l|}{ Copper } \\
\hline Background & 22 & $0.001-0.02$ & 9 & $<0.001$ & - & 0.046 \\
\hline Plume & 14 & $0.01-0.02$ & 0 & - & - & - \\
\hline \multicolumn{7}{|l|}{ Cyanide } \\
\hline Background & 7 & 0.01 & 0 & - & - & - \\
\hline Plume & 9 & 0.01 & 0 & - & - & - \\
\hline \multicolumn{7}{|l|}{ Fluoride } \\
\hline Background & 21 & $0.1-1$ & 48 & $<0.1$ & - & 0.2 \\
\hline Plume & 11 & 0.1 & 100 & 0.1 & 0.9 & 1.3 \\
\hline
\end{tabular}




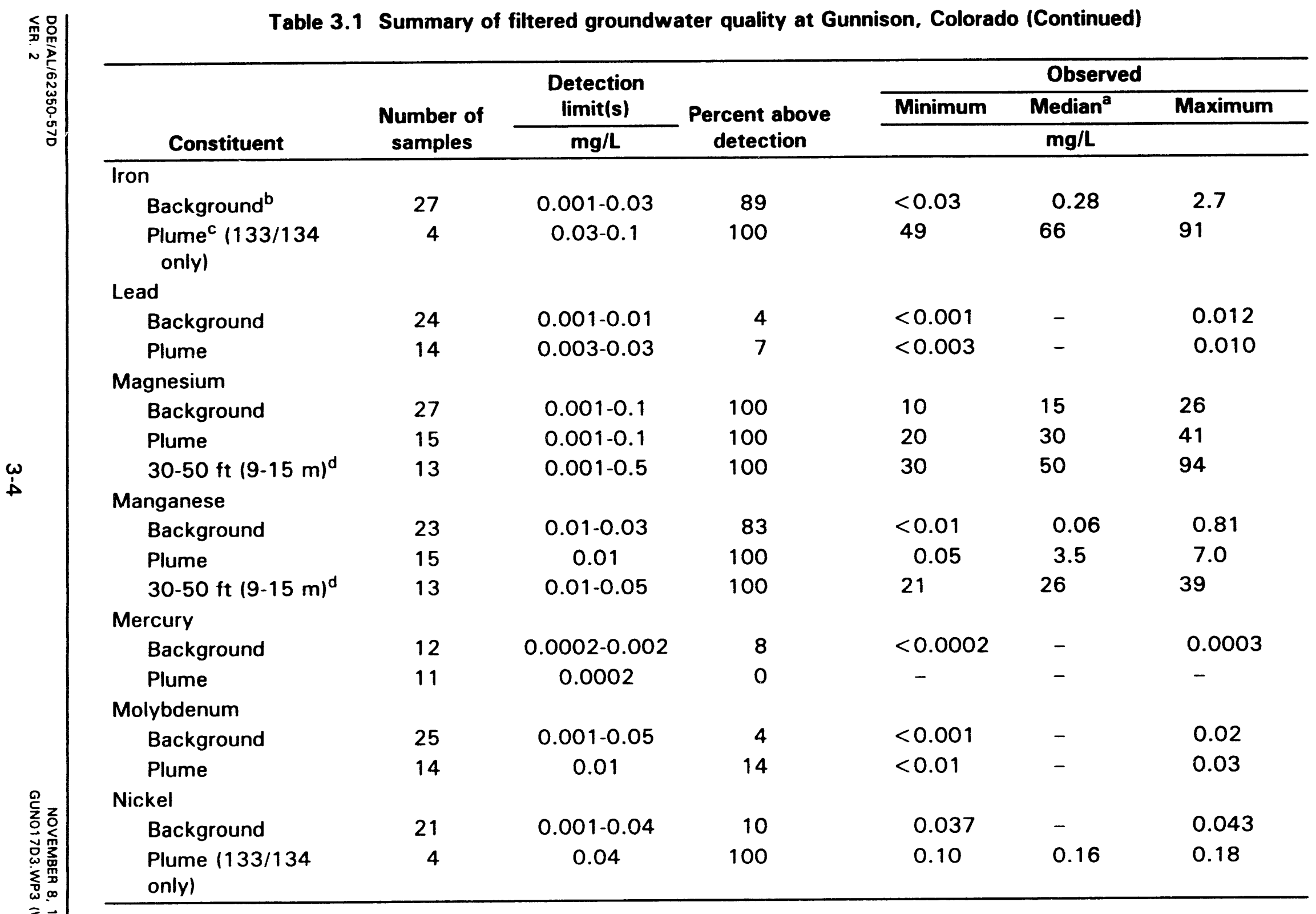




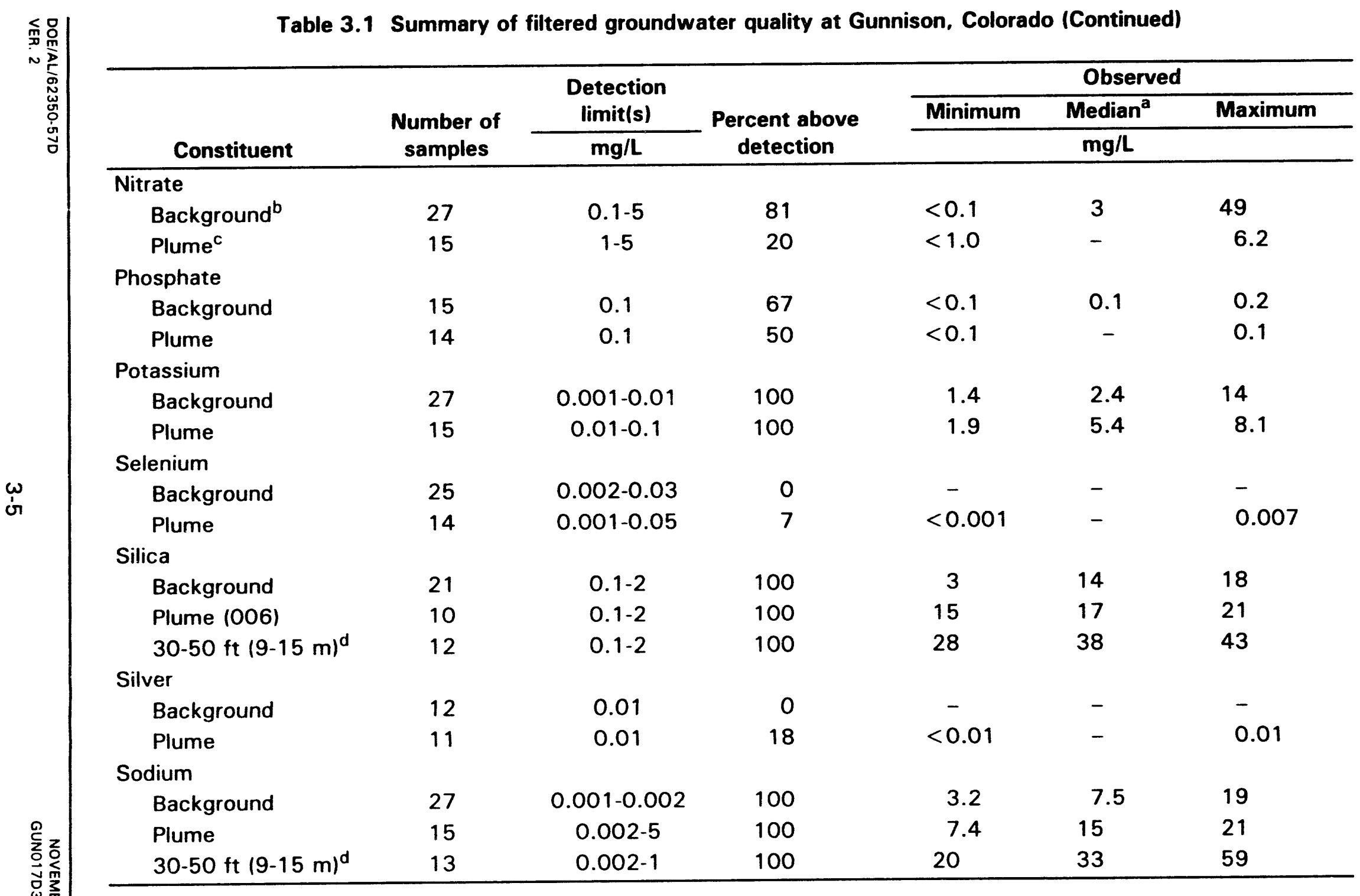




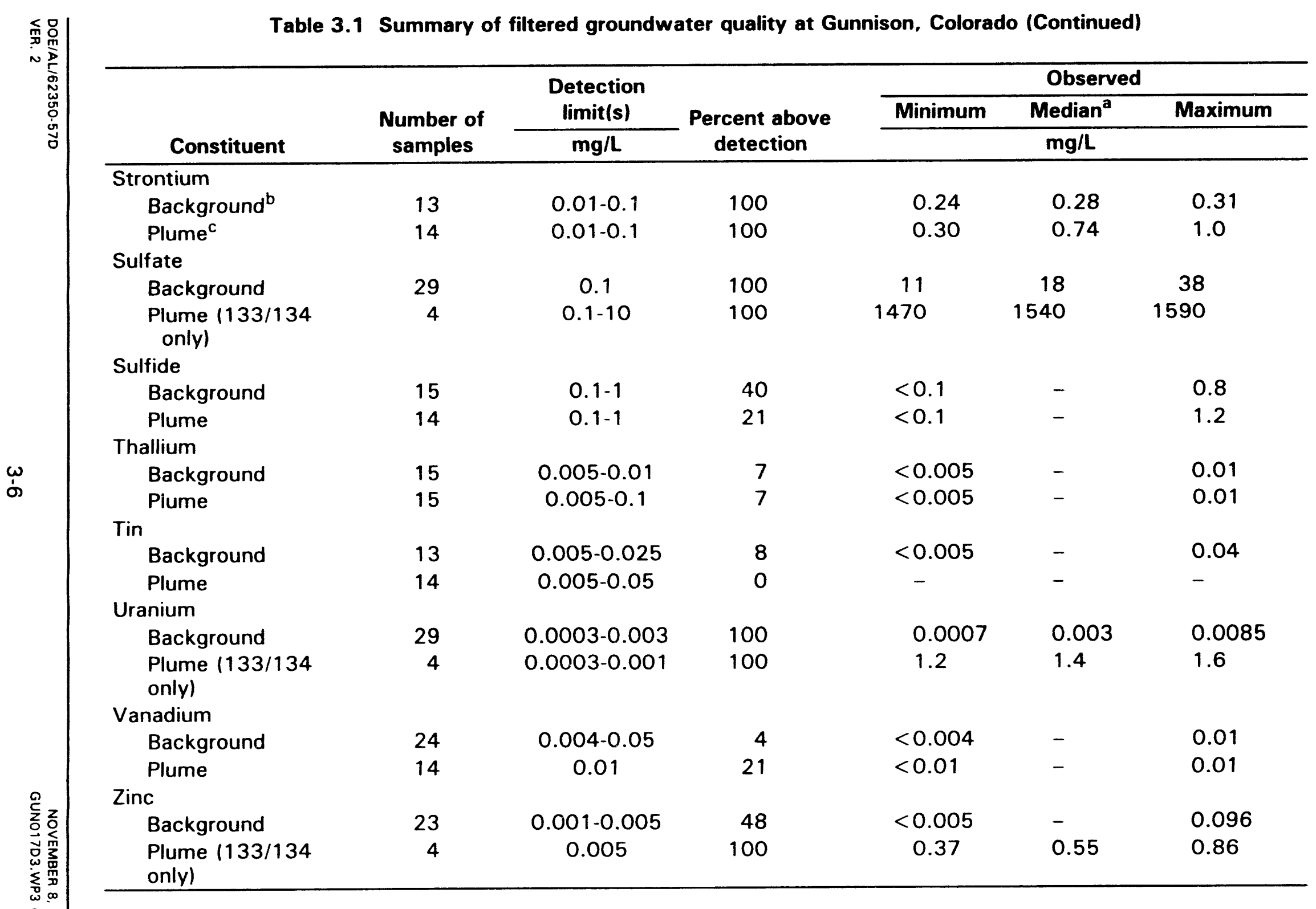




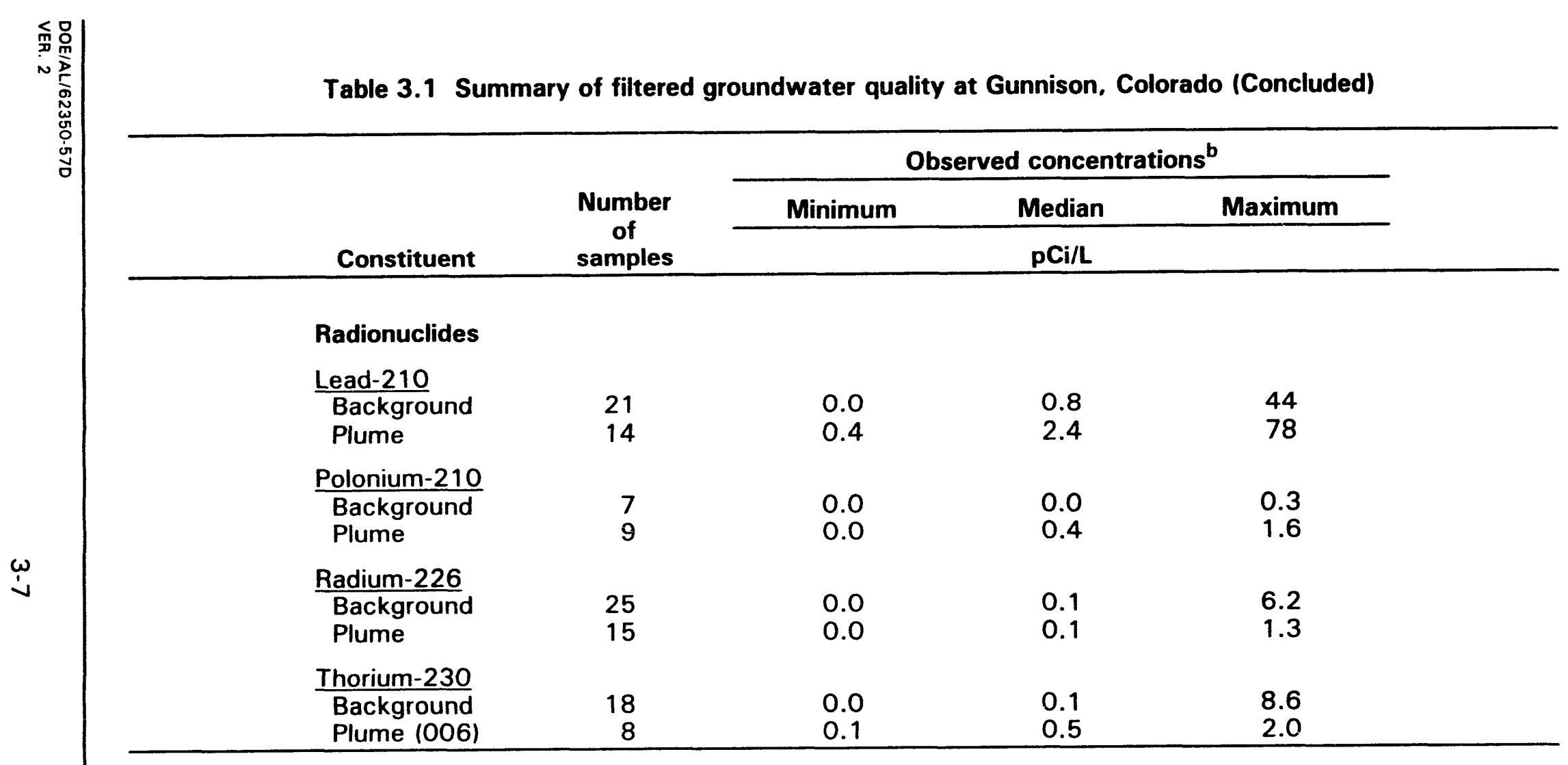

aThe median is the 50 th percentile of the sample data. The median cannot be calculated if 50 percent or less of the data are above detection.

b Background concentrations are from DOE monitor wells 001 and 101 (1989-1993 data), domestic wells 400, 401, 402 , and 422 (1982-1984 data); and city of Gunnison production wells 178 and 179 (1984-1990 data).

cPlume concentrations are from DOE monitor wells 006, 133, and 134 (1989-1993 data) unless otherwise noted. These wells generally have screen depths of 10 to $20 \mathrm{ft}(3$ to $6 \mathrm{~m})$.

${ }^{d}$ Concentrations are from deeper downgradient DOE monitor wells 106, 109, 110, 111, and 112 (1989-1993 data). These wells generally have screen depths of 30 to $50 \mathrm{ft}(9$ to $15 \mathrm{~m})$. 
the background groundwater at this site contains relatively low sulfate and uranium concentrations. Conversely, these constituents are present at relatively high levels in tailings effluent.

Once introduced to the alkaline groundwater typical of the Gunnison processing site, uranium and sulfate behave, chemically, as relatively conservative (mobile) components. Uranium and sulfate serve as excellent tracers of the extent of contamination and plume geometry at this site. Although the highest sulfate and uranium concentrations are found in groundwater relatively close to the tailings pile, concentrations of these constituents that are above background levels are present in groundwater for over $8000 \mathrm{ft}(2400 \mathrm{~m})$ downgradient from the tailings pile (Figures 3.1 and 3.2) (data for all wells). Trend analysis of the chemical data from paired monitor wells $160 / 161$ and $188 / 189$ suggests that the leading edge of the uranium plume may have migrated under the river in deeper alluvial groundwater (Figures 3.3 and 3.4). Most of the domestic wells in the Dos Rios subdivision are drilled in the shallow zone, with depths ranging from 20 to $30 \mathrm{ft}(6$ to $9 \mathrm{~m})$.

Although domestic wells east of the Gunnison River have shown contamination, no domestic wells west of the Gunnison River or in the Island Unit (the area between the two branches of the Gunnison River in the Dos Rios subdivision) have shown elevated contaminant levels.

Although uranium and sulfate are the characteristic contaminants of the distal parts of the Gunnison plume, plots of iron and manganese concentrations versus time (Figures 3.5 and 3.6) for some downgradient monitor wells suggest that elevated levels of these constituents may have also migrated downgradient from the tailings pile. The concentrations of manganese and iron in groundwater at the site are not as evenly distributed throughout the plume as are sulfate and uranium. The possibility that the elevated levels of manganese and iron in the far downgradient monitor wells are due to natural processes and not due to tailings contamination is discussed in Section 3.4.

\subsection{CONTAMINANTS OF CONCERN}

The data presented in Sections 3.1 and 3.2 are summarized in Table 3.1. These data were used to compile a list of contaminants of potential concern for the assessment of human health at the Gunnison site. A constituent was placed on the list of contaminants of potential concern (Table 3.2, column 1) if concentrations of the contaminant in downgradient monitor wells were, on average, higher than those in the background wells. The statistical comparison was made at the 0.05 level of significance. Some additional constituents listed in Table 3.1 show higher median and/or maximum concentrations in downgradient monitor wells than were recorded in background wells (e.g., antimony and chloride). However, for these constituents the differences between background and downgradient data were not large enough or consistent enough to reach statisical significance.

The constituents identified in column 1 of Table 3.2 were screened for their impact on human health using the criteria discussed below to develop a final list of 


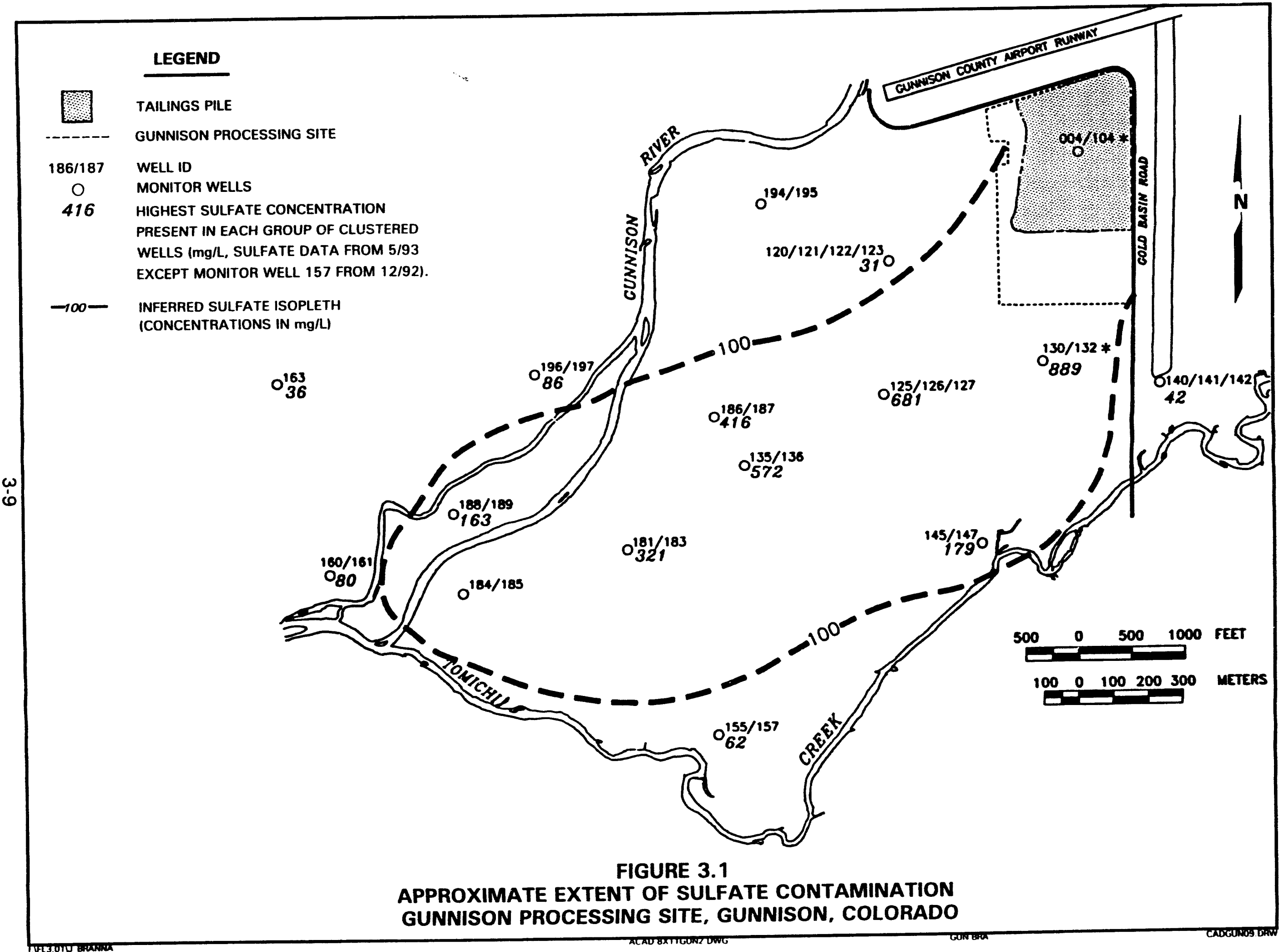




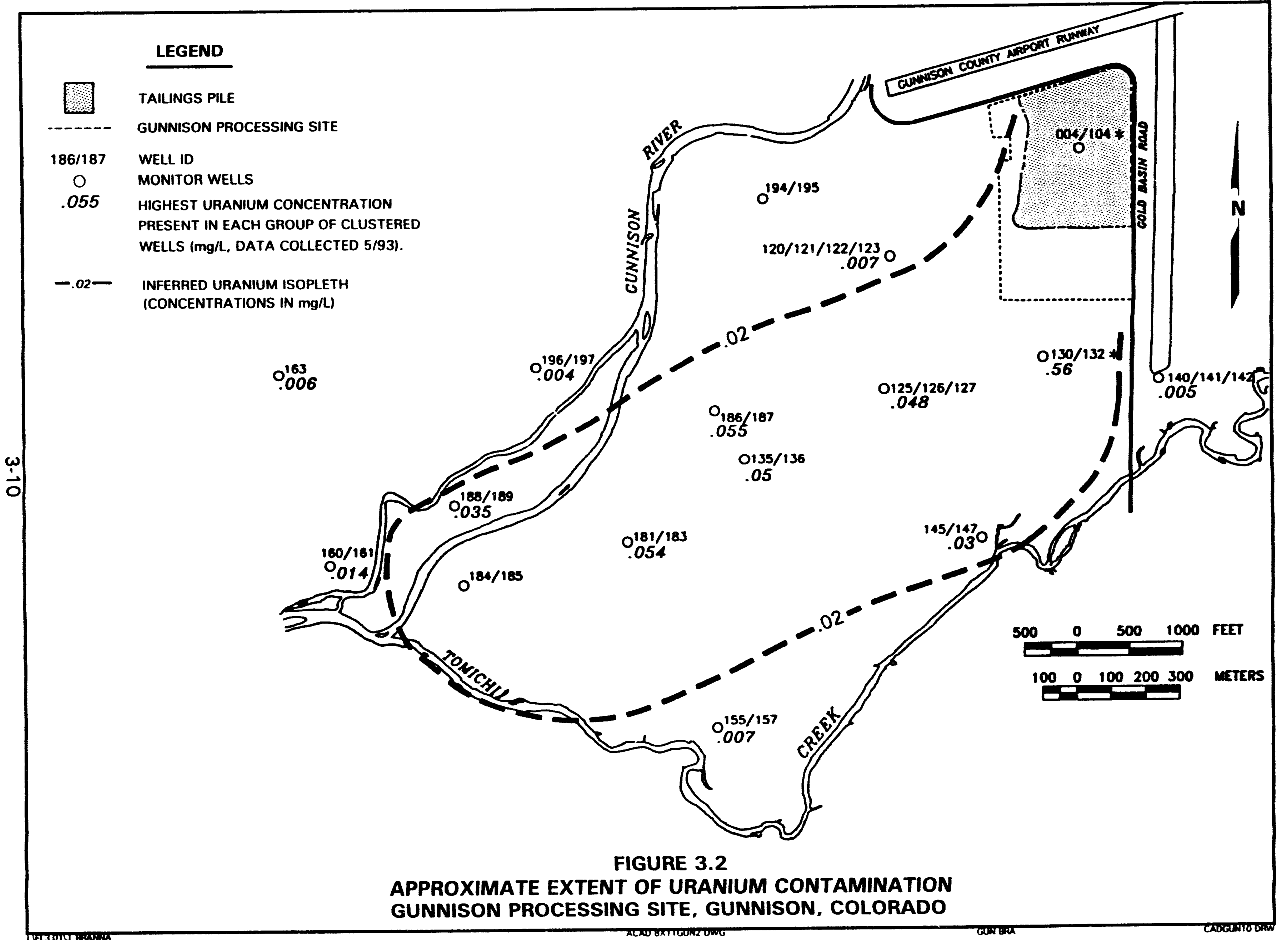




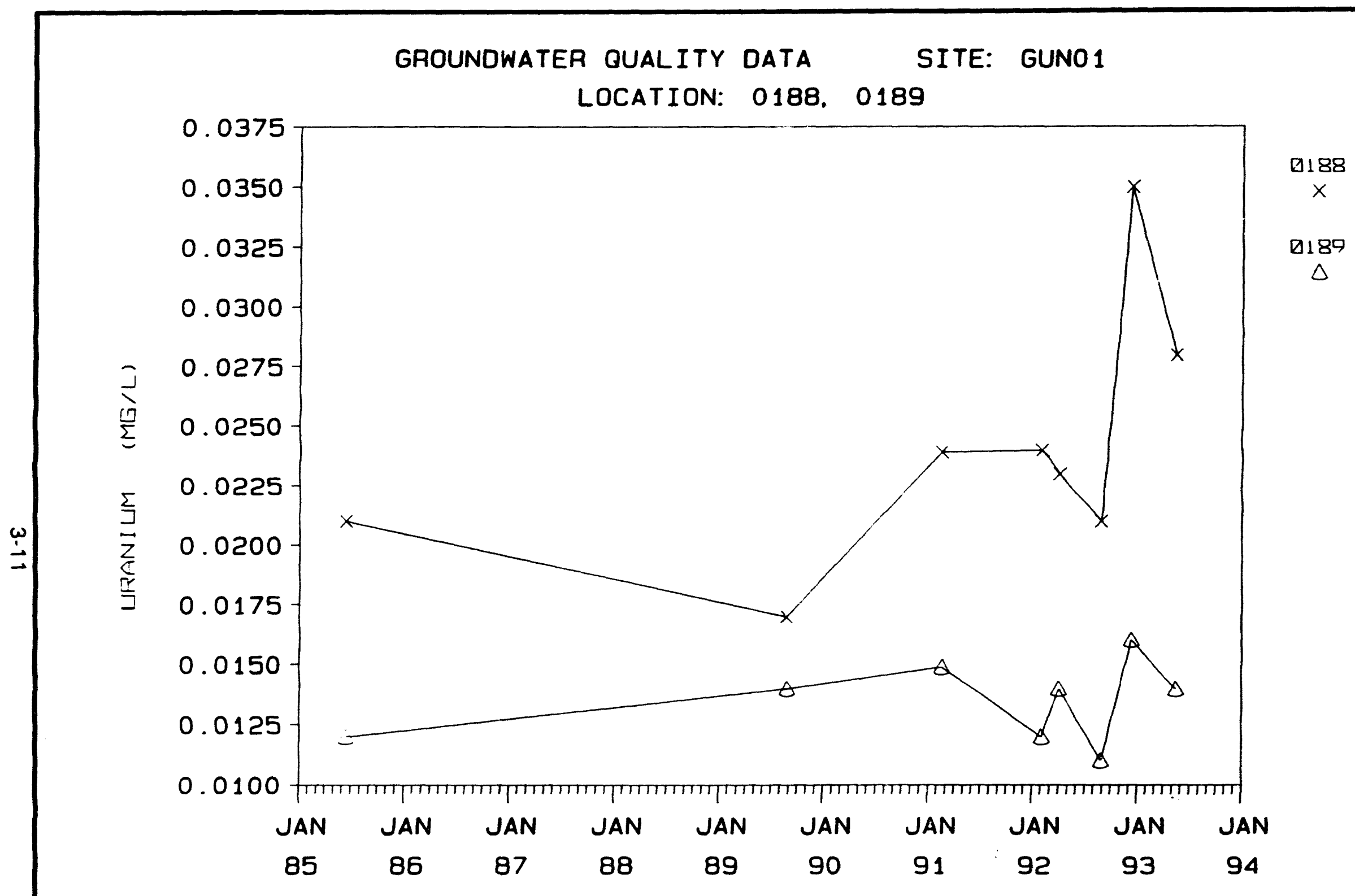

FIGURE 3.3

URANIUM CONCENTRATIONS VS. TIME IN PAIRED MONITOR WELLS 188 AND 189 GUNNISON, COLORADO, SITE 


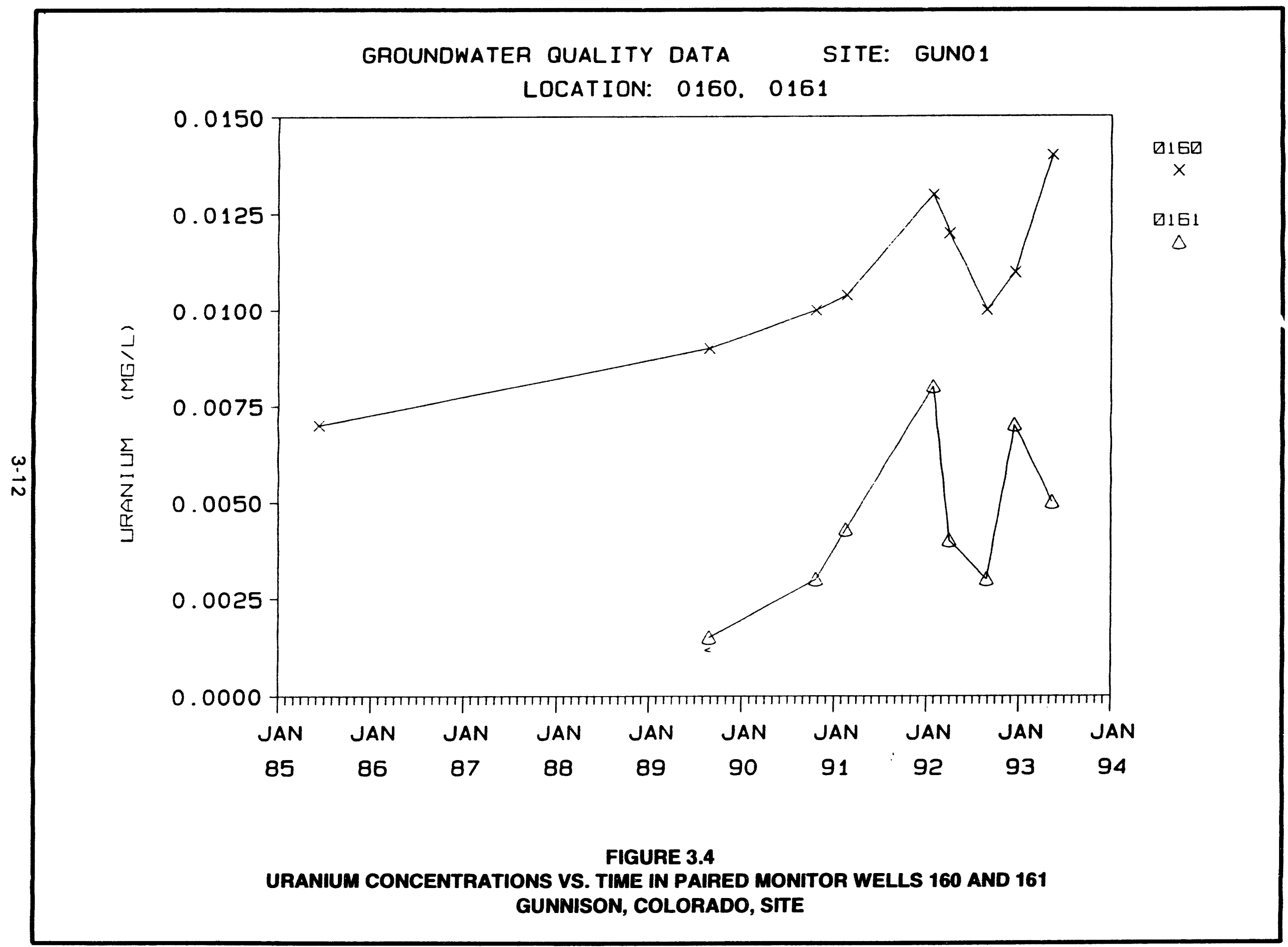




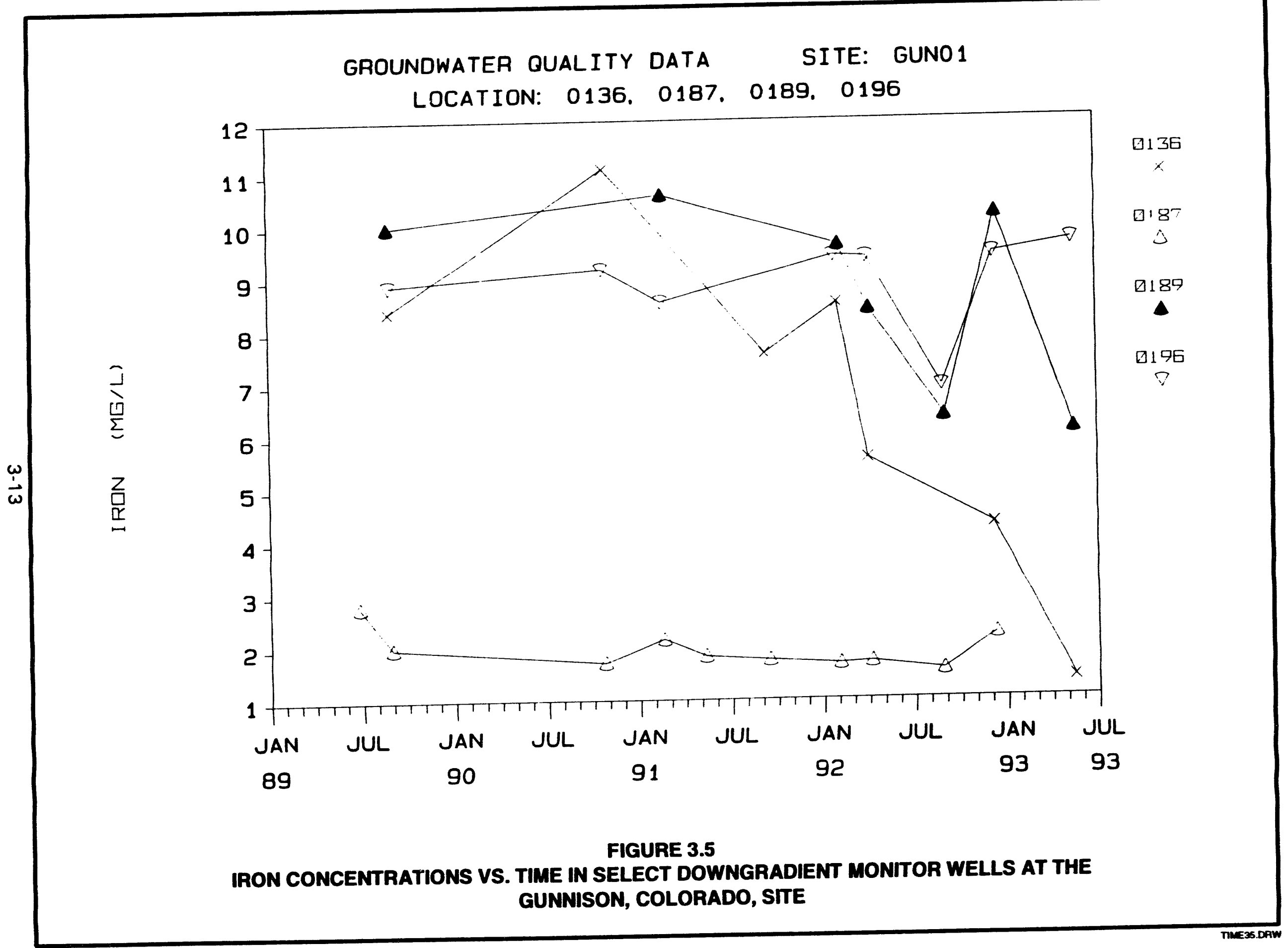




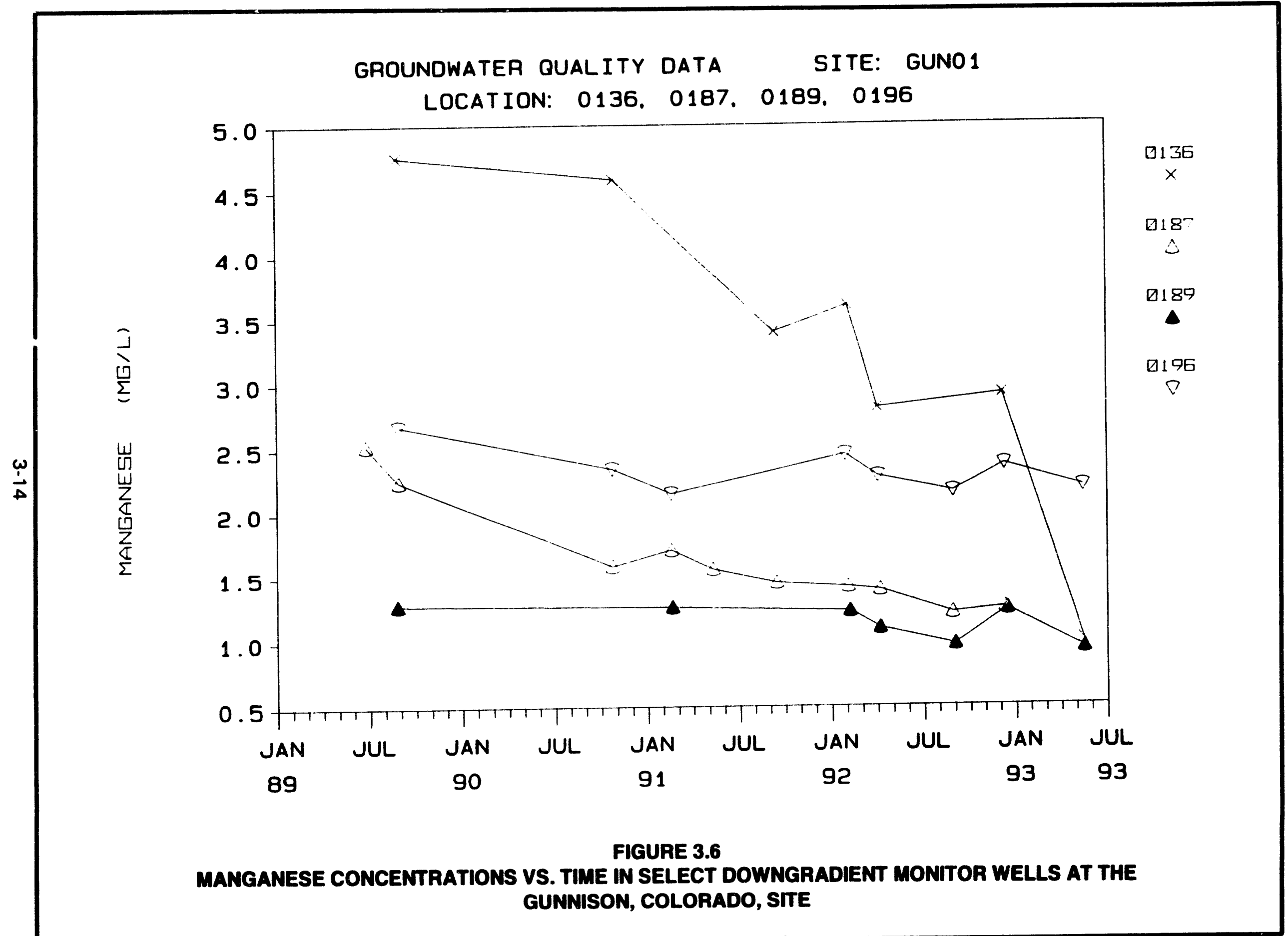


Table 3.2 Contaminants of potential concern for human health evaluation

\begin{tabular}{|c|c|c|c|}
\hline $\begin{array}{l}\text { Contaminant levels that } \\
\text { exceed background }\end{array}$ & $\begin{array}{l}\text { Contaminant levels in } \\
\text { nutritional range }\end{array}$ & $\begin{array}{l}\text { Contaminants of low } \\
\text { toxicity and high } \\
\text { dietary range }\end{array}$ & $\begin{array}{l}\text { Contaminants of } \\
\text { potential } \\
\text { concern }\end{array}$ \\
\hline Ammonium & & Ammonium & \\
\hline Bromide & & Bromide & \\
\hline Calcium & Calcium & & \\
\hline Cadmium & & & Cadmium \\
\hline Cobalt & & & Cobalt \\
\hline Iron & & & Iron \\
\hline Lead-210 & & & Lead-210 \\
\hline Magnesium & Magnesium & & \\
\hline Manganese & & & Manganese \\
\hline Nickel & & Nickel & \\
\hline Polonium-210 & & & Polonium-210 \\
\hline Potassium & Potassium & & \\
\hline Silica & & Silica & \\
\hline Sodium & Sodium & & \\
\hline Strontium & & Strontium & \\
\hline Sulfate & & & Sulfate \\
\hline Thorium-230 & & & Thorium-230 \\
\hline Uranium & & & Uranium \\
\hline Zinc & Zinc & & \\
\hline
\end{tabular}


contaminants of concern for human health. Because environmental effects differ from effects on human health, the complete column 1 list of contaminants will be evaluated in the ecological assessment presented in Section 7.0. Several constituents that were detected above background were deleted from the final list of contaminants of potential concern for human health because they are essential nutrients and the levels at which they are detected are within nutritional ranges. These chemicals include calcium, magnesium, potassium, sodium, and zinc.

Final screening of the remaining contaminants was based on the very low toxicity and relatively high normal dietary intake compared to the values detected. These criteria were used to screen out ammonium, bromide, nickel, silica, and strontium.

After screening based on the criteria described above, the contaminants remaining as contaminants of potential concern were cadmium, cobalt, iron, lead-210, manganese, polonium-210, sulfate, thorium-230, and uranium. These constituents form the basis of the human health portion of the risk assessment for Gunnison.

\subsection{CONTAMINANT FATE AND TRANSPORT}

There is evidence that the groundwater in the alluvial aquifer at the Gunnison site is chemically stratified as a function of depth. Plots of constituents such as $\mathrm{pH}$ and alkalinity show distinct concentration differences as a function of depth in some monitor well clusters or pairs (e.g., background monitor wells 001/101 and far downgradient monitor wells 188/189) (Figures 3.7, 3.8, and 3.9). These variations in water chemistry with depth are unlikely to be caused by plume effects alone and may be due, in part, to differences in groundwater residence time and/or chemical or lithologic variations (e.g., more organic material and/or clay) in the aquifer matrix at various depths. Lithologic logs of drill holes at the Gunnison site confirm that the alluvial aquifer becomes more clayey with depth.

As plume constituents (e.g., uranium, sulfate, manganese) migrate through the aquifer, they interact with the natural, depth-related chemical variations present in the groundwater at this site. These interactions may produce variations in contaminant concentrations with depth that are not simply the result of physical dispersion. These and other chemical controls of specific contaminants of concern for the Gunnison site are discussed below.

\section{Sulfate}

Sulfate concentrations in the highly contaminated parts of the plume immediately adjacent to the tailings are controlled primarily by gypsum solubility. Farther downgradient, sulfate concentrations are controlled largely by physical processes such as dispersion and dilution. 


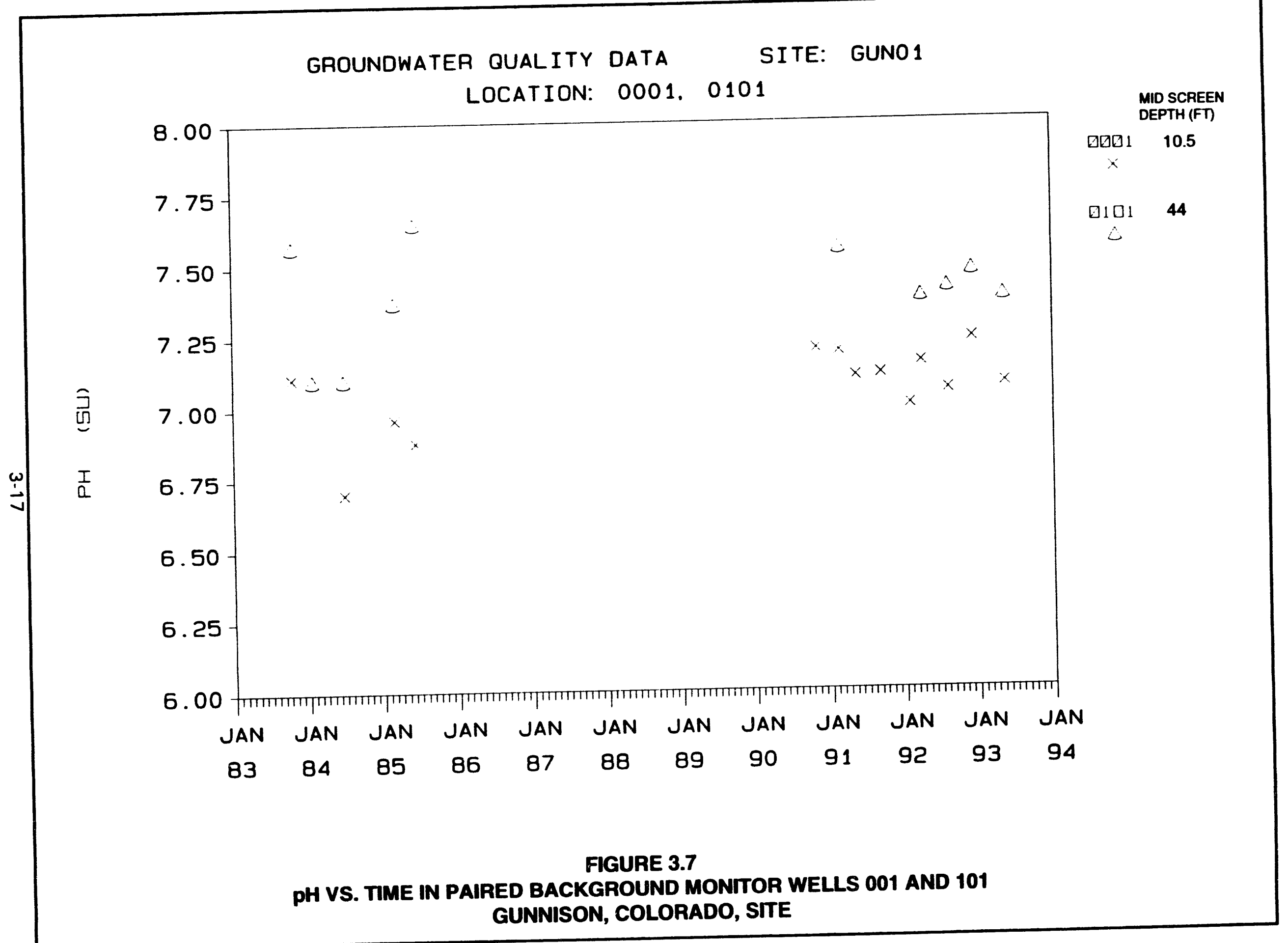




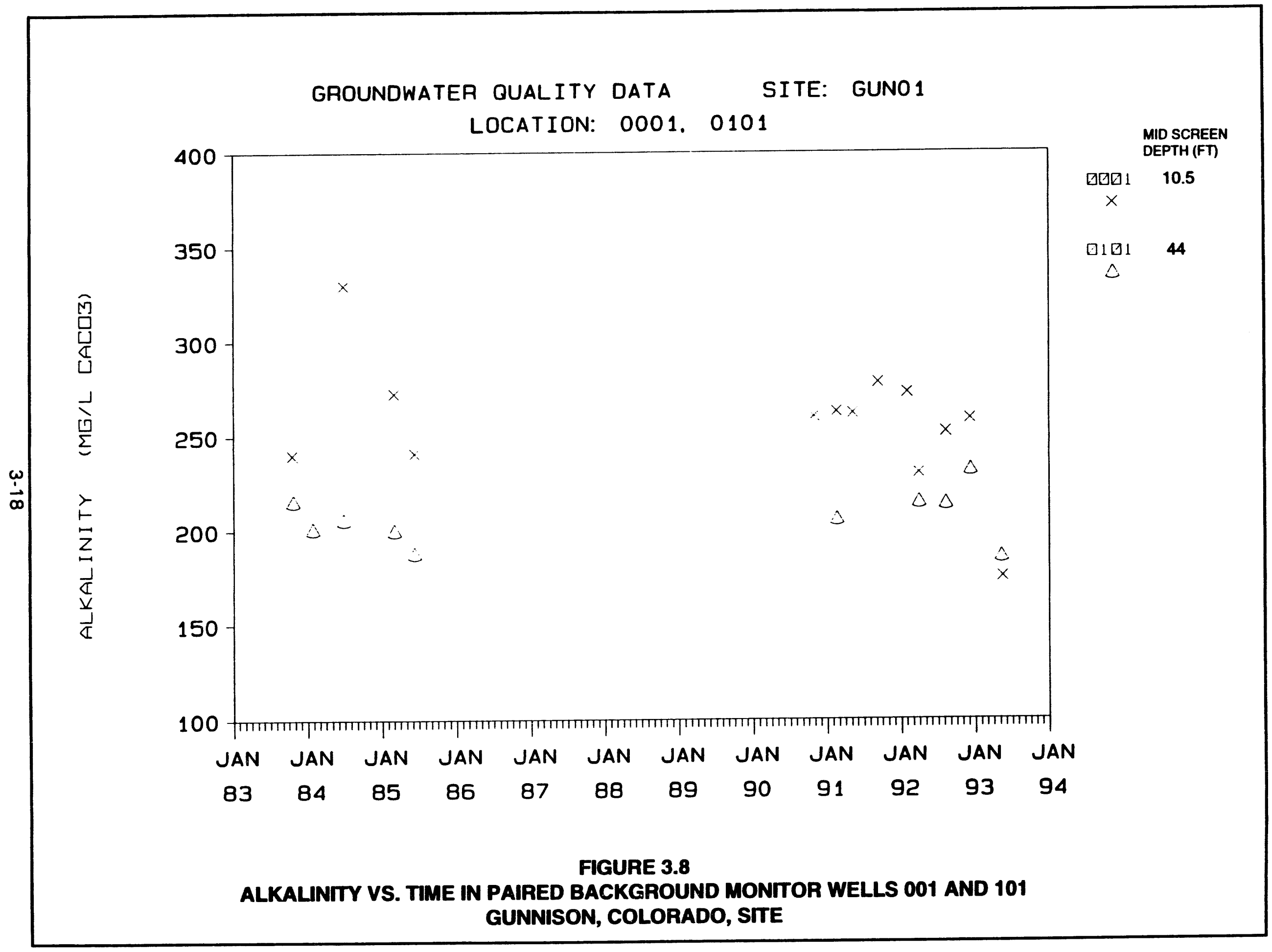




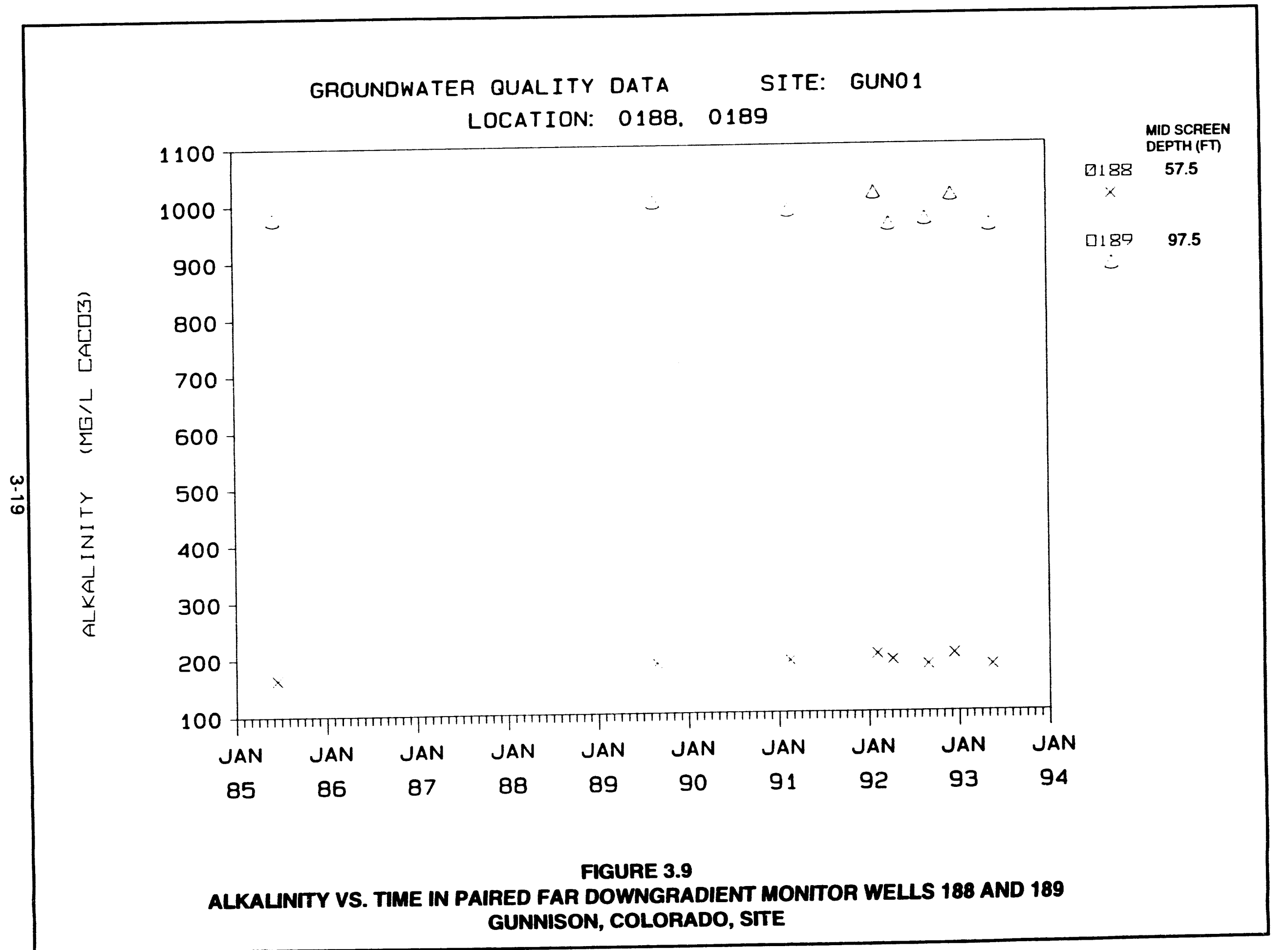




\section{Uranium}

Uranium is relatively mobile in oxidizing, alkaline groundwater over a range of elevated $\mathrm{pH}$ values (e.g., between 6.5 and 8.5$)$. Under these conditions, uranium can form stable carbonate complexes that facilitate transport in groundwater. Higher groundwater pHs tend to decrease the sorption of these uranium species by aquifer materials even further. These processes result in the large uranium plume at the Gunnison site.

\section{Iron and manganese}

Very high concentrations of iron (ranging up to about 90 to $100 \mathrm{mg} / \mathrm{L}$ ) have been found in groundwater taken from monitor wells through the tailings (e.g., monitor well 104) and within the old ore storage area along the southern margin of the tailings pile (e.g., monitor wells 006,007, and 009) (Figure 3.10). Within this area, iron concentrations are generally much higher in groundwater from shallow monitor wells [screened generally between 10 and $20 \mathrm{ft}(3$ and $6 \mathrm{~m})$ ] than in groundwater from adjacent wells $(106,107$, and 109) that are screened more deeply (between 30 to $60 \mathrm{ft}(9$ to $18 \mathrm{~m}) \mathrm{l}$. This drop in iron concentrations with depth is not reflected by a similar precipitous drop in sulfate or manganese concentrations (manganese concentrations actually increase with depth). The drop in iron concentrations cannot, therefore, be attributed simply to the dilution of tailings contaminated groundwater at these slightly greater depths. However, this abrupt drop in iron concentrations is consistent with the fact that elevated levels of iron are typically not stable in groundwater that is oxidizing and that has a pH near 6 or above. Dissolved iron in oxidizing water with a $\mathrm{pH}$ of 7 should be rapidly hydrolyzed and precipitated as iron oxyhydroxides.

Very high manganese concentrations have also been found in groundwater sampled along the southern margin of the tailings pile labout $80 \mathrm{mg} / \mathrm{L}$ in monitor wells 106 and 111). Aqueous species of $\mathrm{Mn}^{2+}$ are more stable than $\mathrm{Fe}^{2+}$ species under relatively oxidizing and alkaline conditions, and manganese should be more mobile than iron in the Gunnison alluvial aquifer. As discussed above, elevated levels of manganese are found considerably deeper in the aquifer under and adjacent to the tailings pile than is iron. Nevertheless, the adsorption of manganese species onto the aquifer matrix and the precipitation of rhodochrosite $\left(\mathrm{MnCO}_{3}\right)$ should be important factors in eventually reducing manganese levels to near background levels in the Gunnison alluvial aquifer. The rate at which a combination of adsorption and precipitation processes will attenuate manganese at this site cannot be determined without further study.

Some far downgradient monitor wells (e.g., 136, 187, 189, 196) have had water samples with iron concentrations up to 10 to $12 \mathrm{mg} / \mathrm{L}$ and manganese levels that were recently as high as 4 to $5 \mathrm{mg} / \mathrm{L}$ (Figures 3.5 and 3.6). Monitor wells 196 and 189 are located at least $5000 \mathrm{ft}(500 \mathrm{~m})$ downgradient and 196 is on the other side of the Gunnison River from the tailings (Figure 2.5). A cursory analysis of these data might suggest that iron and manganese are extremely mobile in the Gunnison 


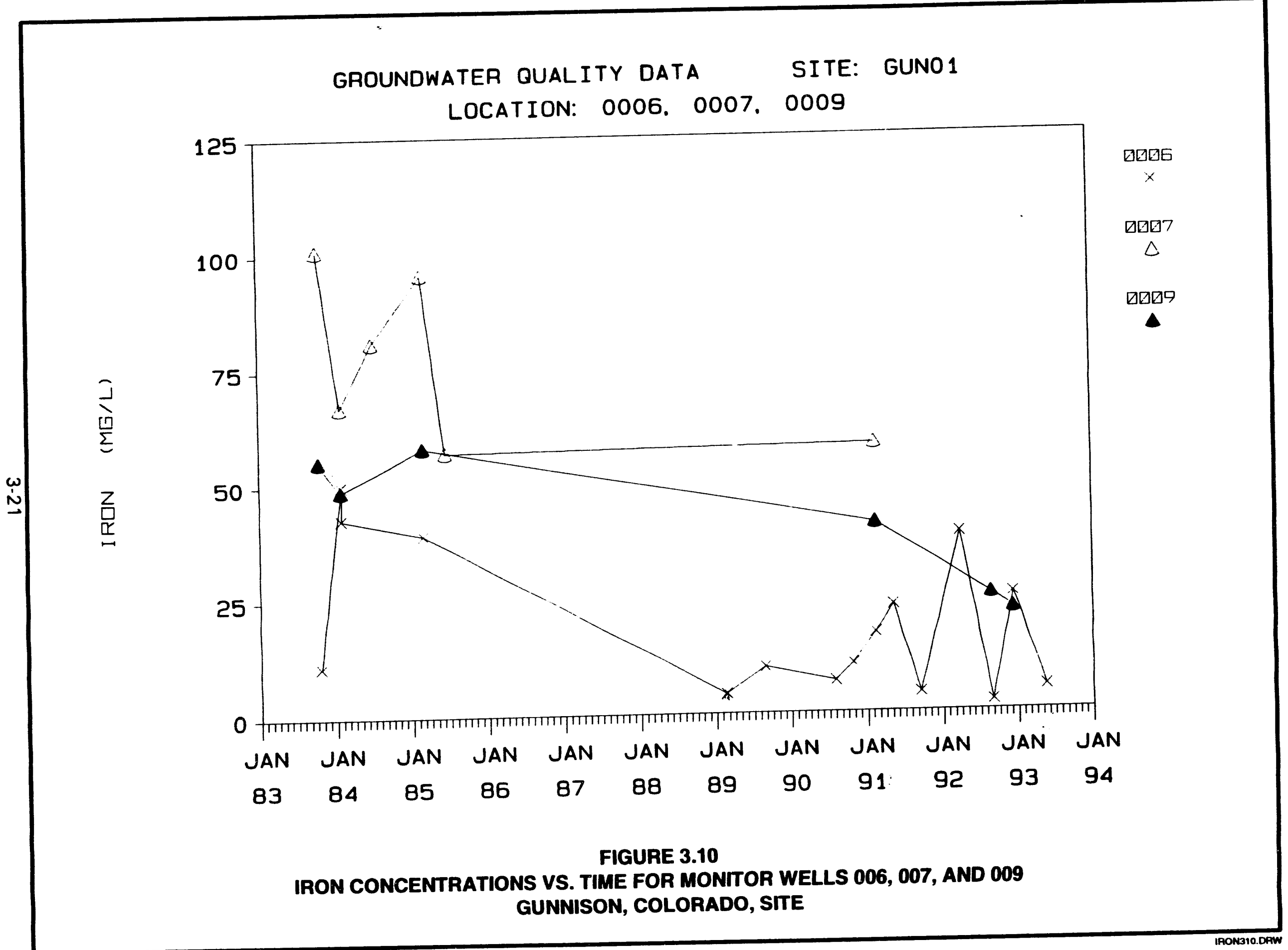


aquifer and that these wells contain iron and manganese derived from the tailings. A more detailed review suggests that other sources of elevated iron and manganese concentrations may be present at this site.

Groundwater from both of these wells has relatively low sulfate (generally 80 to $160 \mathrm{mg} / \mathrm{L})$, and uranium contamination appears to be relatively low. Given that sulfate and uranium in alkaline aquifers are generally considered to be far more mobile than iron or manganese, the low concentrations of these more mobile constituents suggest that the elevated levels of iron and manganese are from another source. Naturally reducing conditions can stabilize reduced iron and manganese species in solution. The extremely high alkalinity present in these wells ( $>1000 \mathrm{mg} / \mathrm{L}$ as $\mathrm{CaCO}_{3}$ ) is consistent with the oxidation of organic material, and alkalinity this high would help stabilize manganese in solution as $\mathrm{MnHCO}_{3}{ }^{+}(\mathrm{Hem}$, 1970). If this hypothesis is correct, the elevated concentrations of iron and manganese in these monitor wells may be due to natural conditions le.g., locally more reducing conditions due to the presence of abundant organics) and are not necessarily due to the impact of tailings contamination.

\section{Cobalt}

Elevated cobalt levels have been introduced to the alluvial aquifer by acidic tailings leachate. However, because of its chemical similarity to iron and manganese, this constituent is typically strongly sequestered by the precipitation of manganese and iron hydroxides. At the typical $\mathrm{pH}$ range $(6.0$ to 8.0$)$ observed for the groundwater in the alluvial aquifer at Gunnison, cobalt should be present at levels at or below detection limits except in the area immediately adjacent to the tailings (where the aquifer is continually receiving tailings effluent).

\section{Cadmium}

Cadmium will be rapidly removed by the precipitation of octavite $\left(\mathrm{CdCO}_{3}\right)$ and by hydrolysis and adsorption reactions as the low $\mathrm{pH}$ tailings leachate is neutralized by alkaline groundwater and the calcite in the aquifer matrix. Dilution with background water should produce cadmium concentrations in downgradient groundwater that are typically below detection limits, while detectable levels of cadmium should be restricted to the areas underneath or immediately adjacent to the tailings pile.

\section{Lead-210}

The fate and transport processes that affect lead-210 are those that affect lead concentrations in general. The following discussion of lead geochemistry was derived primarily from Rai and Zachara (1984). The dominant aqueous species of lead will be $\mathrm{Pb}^{2+}$ in acidic environments and $\mathrm{Pb}^{2+}$-carbonate complexes in alkaline environments. $\mathrm{PbCO}_{3}$ (cerrusite) is a major control on lead concentrations in alkaline, carbonate-rich systems such as the alluvial aquifer at Gunnison. Iron and 
manganese hydroxides are strong adsorbents of lead and should also be major controls on lead solubility at Gunnison. Given these strong controls on lead solubility and transport in alkaline systems, lead-210, if introduced into the groundwater system, should be rapidly removed from solution at Gunnison and stabilized in the aquifer matrix.

\section{Polonium-210}

Polonium-210 is produced by the beta decay of lead-210 (half-life equals 22 years) through the intermediate short-lived daughter bismuth-210 (half-life equals 5.02 days). Polonium -210 has a half-life of about 140 days, and it decays to stable lead-206. Because lead-210 has a much longer half-life than bismuth-210 or polonium-210, the distribution of polonium-210 in this aquifer will be controlled primarily by the distribution of lead- 210 .

\section{Thorium-230}

Thorium is moderately soluble and mobile in sulfate-rich, low-pH lup to a $\mathrm{pH}$ of about 4.5 to 5.0 ) aqueous solutions. However, once the $\mathrm{pH}$ of a thorium-bearing acidic solution rises to about 5.0, hydrolysis and precipitation of thorium rapidly occurs. Therefore, except in the immediate subpile region of the Gunnison tailings pile, thorium-230 levels should approach background levels.

\subsection{SURFACE WATER MONITORING}

The locations of five surface water sampling points are shown in Figure 3.11. Two sampling points are located in the Gunnison River, one upstream (location 775) and one downstream (location 776) of the site. Tomichi Creek also has been sampled upstream (location 778) and downstream (location 777) of the site. The fifth sampling point is the pond (location 779) used for pay fishing at the campground. Filtered surface water samples were collected from each location in August 1989. In October 1990, unfiltered samples were collected from all the locations except downstream of the site in Tomichi Creek. In May 1993, unfiltered samples were collected from each location.

Surface water data from the Gunnison River and Tomichi Creek show that most of the constituents detected at the downstream locations were not greater than their respective background (upstream) concentrations. For the list of groundwater constituents that are identified as exceeding background groundwater quality (Table 3.2), only silica was detected in Gunnison River water at a concentration above the background river water concentration. However, this is not considered significant because the downstream concentration was only 2 percent higher than the upstream concentration, and silica is not considered a site-related contaminant. Three constituents from this list (calcium, magnesium, and sulfate) were detected in Tomichi Creek at concentrations slightly higher than detected at the background 


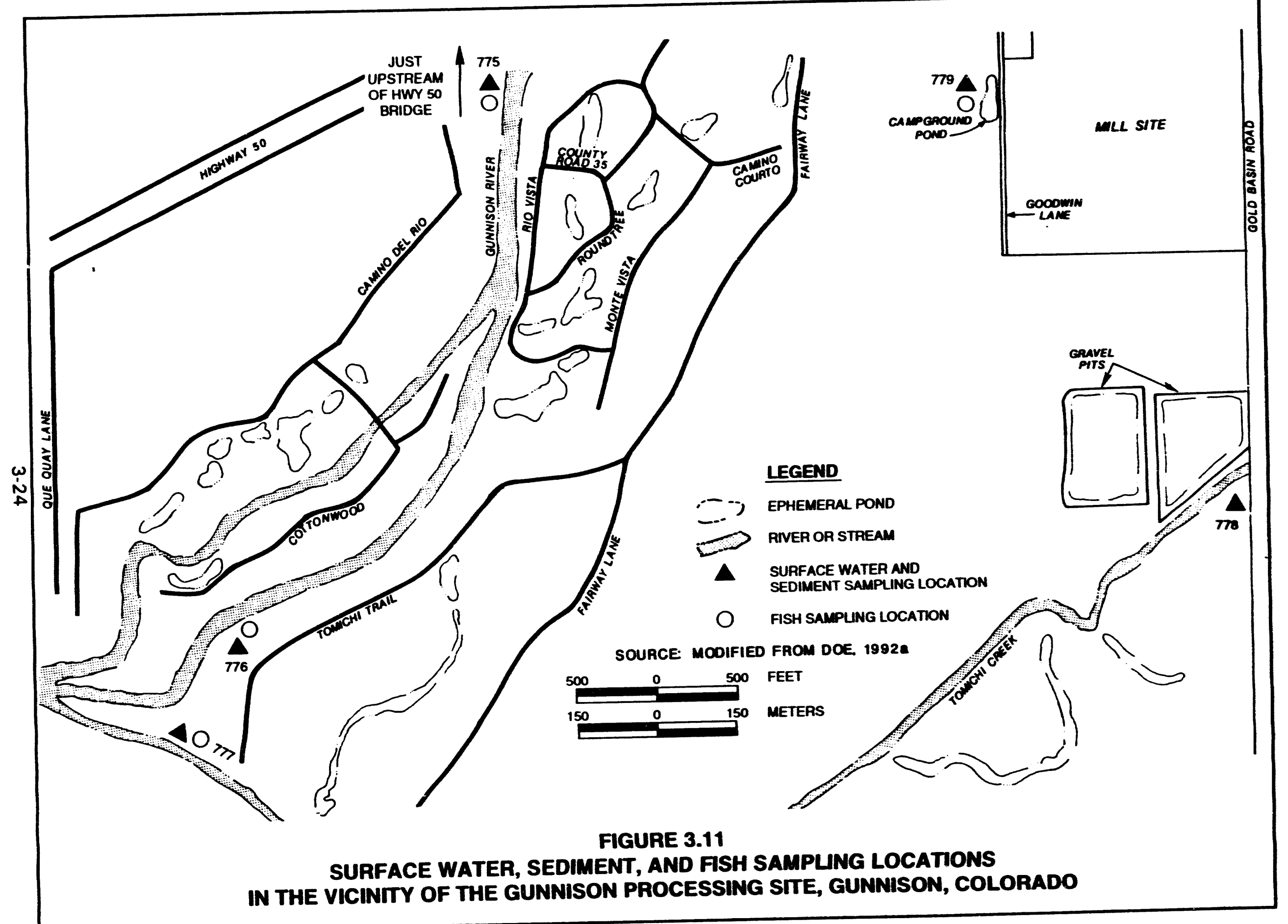


location. No mathematical analysis can be conducted to determine whether these constituent concentrations are statistically above background concentrations because of the limited amount of surface water data. However, the downstream concentrations of calcium and magnesium are only slightly higher (approximately 8 percent) than the upstream concentrations, while the sulfate concentration is approximately 30 percent higher than the upstream concentration. Two constituents (iron and zinc) were detected in water from the campground pond at concentrations above background in the Gunnison River and Tomichi Creek. However, it is not known whether these concentrations represent a statistically significant elevation above background levels.

Precipitation and snowmelt may have carried both dissolved and suspended constituents along surface drainages to the Gunnison River, Tomichi Creek, and the campground pond. Metal constituents transported as dissolved species would have become diluted after discharging to these water bodies. Alternatively, dissolved species could have precipitated, becoming adsorbed to sediments or absorbed into biota with varying biochemical and geochemical conditions. Constituents transported from the disposal site that were sorbed onto soil particles would have been deposited as sediments. Variations in geochemical conditions or biological action could release constituents adsorbed onto sediments into surface waters. Thus, deposited sediments could act as a source of site-related surface water contamination. 


\subsection{EXPOSURE ASSESSMENT}

\subsection{POTENTIALLY EXPOSED POPULATION}

Exposure can occur only if there is both a source of contamination and a mechanism of transport to a receptor population or individual. Bottled water is available to all residents downgradient of the site who have domestic wells potentially affected by the plume of contaminated groundwater. However, the potential exists that water from these wells could still be used for drinking, as well as to water livestock or irrigate garden plants. Using the livestock for food would create an exposure pathway to humans. Plants with roots in the alluvial aquifer or irrigated with water from this zone could take up and concentrate contaminants, forming a pathway to humans through plant consumption. Finally, a domestic well could be drilled or hand-dug in the alluvial aquifer, creating an exposure pathway through drinking and bathing water.

Although the potential exists that people may be exposed to contaminated groundwater from downgradient domestic wells, a future groundwater use scenario at the former processing site is assumed for purposes of this risk assessment. This scenario evaluates domestic groundwater use consistent with current use by the rural population in the region. The potentially exposed population includes individuals of the following age groups: infants (birth to 1 year old), children (1 to 10 years old), and adults $(11$ to 64 years old). These age groups were selected for the following reasons:

- Survey data for population variables such as age, weight, and daily water intake are available for these age groups.

- Toxicological variables are similar within these age groups, including responsiveness of sensitive subgroups (infants and children) to the contaminants of concern, toxicant intake to body weight ratios, and toxicokinetics.

\subsection{EXPOSURE PATHWAYS}

Groundwater in the region is primarily used for household purposes such as drinking, cooking, and bathing. Other uses typical of the region that could indirectly lead to human exposure include irrigation and livestock watering. Figure 4.1 provides a conceptual model for potential groundwater exposure pathways that could result from these uses.

\subsubsection{Drinking water ingestion}

Drinking water ingestion is generally the most significant exposure pathway for groundwater contaminated with metals and other nonvolatile compounds. For this 


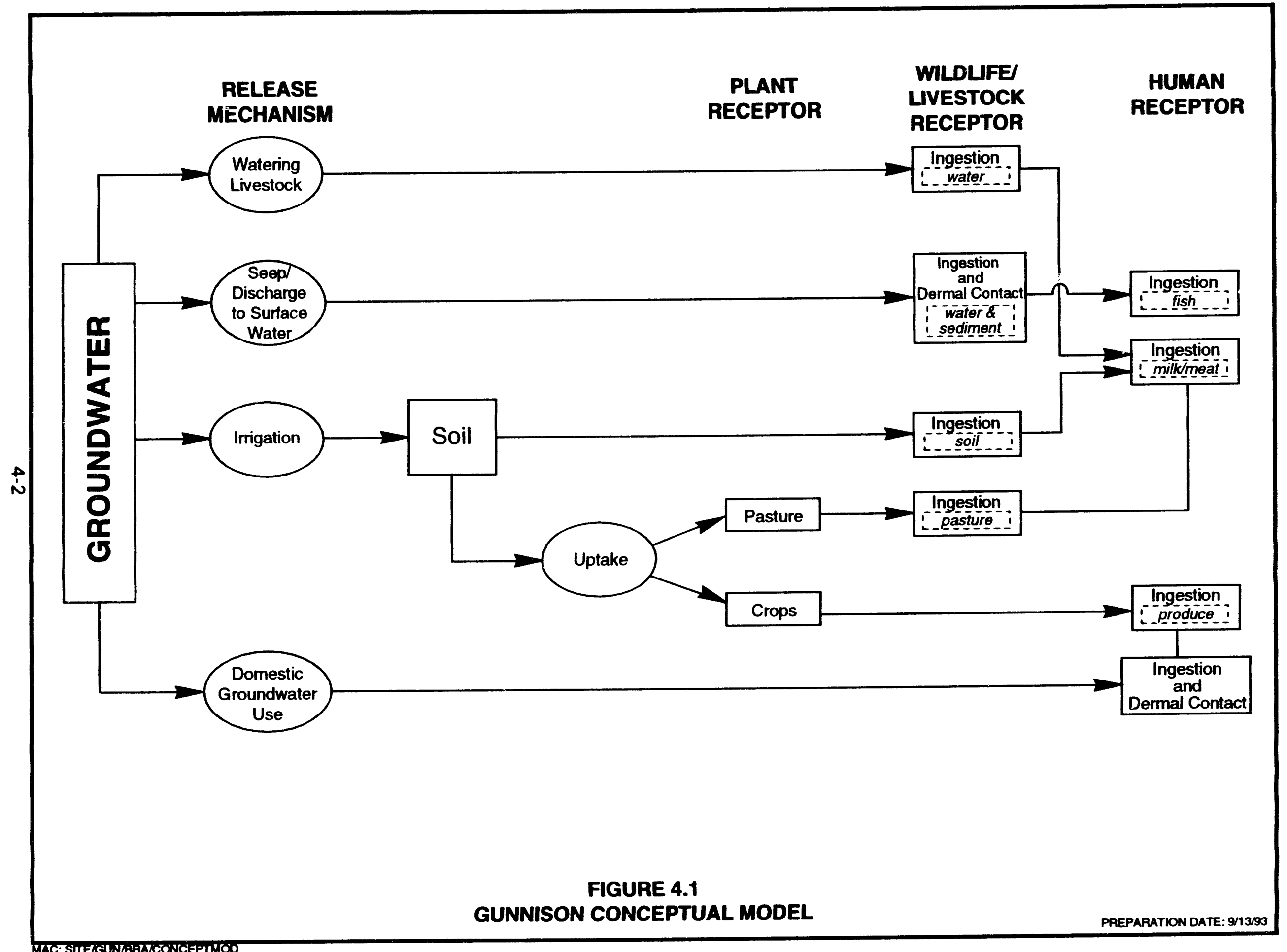


evaluation, drinking water consumption includes water consumed for drinking, as well as water used for food preparation (e.g., reconstituted juices, soup, rice, and beans). For comparison of relative pathway significance, a screening level assessment of drinking water intake is shown in Table 4.1. These calculations are based on estimates of the maximum concentrations of contaminants within the plume li.e., the maximum detected concentration from the most contaminated plume wells).

\subsubsection{Dermal absorption}

Dermal absorption is the process by which chemicals coming into contact with the skin are absorbed into the blood vessels near the surface of the skin. Some compounds are absorbed easily in this manner, though metals do not possess the chemical properties that are conducive to skin absorption.

To evaluate this exposure route, a screening calculation was performed to determine if a dermal absorption pathway would be significant compared to the drinking water pathway for the contaminants of concern. Since chemical-specific absorption factors are not available for these contaminants, it was assumed that they are absorbed across the skin at the same rate as water. This assumption will probably overestimate any potential contribution from dermal absorption. Additionally, the concentration in water was assumed to be the maximum detected concentration from the most contaminated plume wells, which also will overestimate exposure.

The results of the screening are given in Table 4.1. Based on these results, dermal absorption was eliminated from more detailed evaluation at this time because it contributed to less than 1 percent of the total intake from drinking water for all constituents.

\subsubsection{Ingestion of groundwater-irrigated produce}

This exposure route was also evaluated for its relative significance to the drinking water ingestion route. The results of the screening calculation are shown in Table 4.2. The assumptions for this evaluation will probably overestimate the potential for exposure from this route, because it is assumed that this garden would be the source of all garden produce in the diet. The results of this screening show that for the contaminants of potential concern at this site, ingesting garden vegetables and fruit irrigated with contaminated groundwater would lead to potential exposures of 2 percent or less of that associated with drinking water ingestion. Thus, this pathway is eliminated from further evaluation, although the impact of this additional source will be discussed in Sections 6.1 and 6.2. 
Table 4.1 Exposure dose calculations and equation definitions for groundwater ingestion and dermal contact, Gunnison UMTRA Project site, Gunnison, Colorado

\begin{tabular}{|c|c|c|c|c|}
\hline \multirow{2}{*}{$\begin{array}{l}\text { Contaminant of } \\
\text { concern }\end{array}$} & \multirow{2}{*}{$\underset{(m g / L)}{C w}$} & \multicolumn{2}{|c|}{$\begin{array}{l}\text { Groundwater exposure doses } \\
\text { (mg/kg/day) }\end{array}$} & \multirow{2}{*}{$\begin{array}{l}\text { Ratio of } \\
\text { dermal: } \\
\text { ingestion }\end{array}$} \\
\hline & & Ingestion & Dermal contact & \\
\hline \multicolumn{5}{|l|}{ Noncancer effects } \\
\hline Cadmium & 0.004 & $1 E-04$ & $2 E-07$ & 0.002 \\
\hline Cobalt & 0.37 & $1 E-02$ & $2 E-05$ & 0.002 \\
\hline Iron & 91 & $3 E+00$ & $5 E-03$ & 0.002 \\
\hline Manganese & 39 & $1 E+00$ & $2 \mathrm{E}-03$ & 0.002 \\
\hline Sulfate & 1590 & $4 E+01$ & $9 E-02$ & 0.002 \\
\hline Uranium & 1.6 & $4 E-02$ & $9 E-05$ & 0.002 \\
\hline Cancer effects & (pCi/L) & & & \\
\hline Lead-210 & 78 & $2 E+06^{a}$ & $3 E+03^{a}$ & 0.002 \\
\hline Polonium-210 & 1.6 & $3 E+04^{a}$ & $7 E+01^{a}$ & 0.002 \\
\hline Thorium-230 & 2.0 & $4 E+04^{a}$ & $8 E+01^{a}$ & 0.002 \\
\hline Uranium $^{\mathbf{b}}$ & 1100 & $2 E+07^{a}$ & $5 E+04^{a}$ & 0.002 \\
\hline
\end{tabular}

Equation definitions for exposure dose calculations

Ingestion of groundwater - noncarcinogens:

$\begin{array}{ll}\text { Chronic daily intake }(\mathrm{mg} / \mathrm{kg} / \text { day }) & =\frac{\mathrm{Cw} \times \operatorname{IRw} \times \mathrm{EF} \times \mathrm{ED}}{\mathrm{BW} \times \mathrm{AT}} \\ \text { Radionuclides }(\mathrm{pCi}) & =\mathrm{Cw} \times \operatorname{R} w \times E F \times E D\end{array}$

Dermal contact with groundwater - noncarcinogens:

Chronic daily intake $(\mathrm{mg} / \mathrm{kg} /$ day $)=\frac{(\mathrm{CW} \times \mathrm{SA} \times \mathrm{Pc} \times \mathrm{Cf}) \times \mathrm{ET} \times \mathrm{EF} \times \mathrm{ED}}{\mathrm{BW} \times \mathrm{AT}}$

Radionuclides $(\mathrm{pCi}) \quad=\quad \mathrm{CW} \times \mathrm{SA} \times \mathrm{PC} \times \mathrm{Cf} \times \mathrm{ET} \times \mathrm{EF} \times \mathrm{ED}$

Where:
$\mathrm{Cw}_{w}=$ Contaminant concentration in groundwater (maximum concentration detected) (mg/L or $\mathrm{PCi} / \mathrm{L})$.
$I R w=$ Ingestion rate for water (L/day) $(2 \mathrm{~L} /$ day for an adult).
$\mathrm{EF}=$ Exposure frequency ( 350 days/year).
$E D=$ Exposure duration ( 30 years for an adult).
$B W=$ Body weight $(70 \mathrm{~kg}$ for an adult).
AT $=$ Averaging time (365 days $\times$ ED for noncarcinogens).
SA $=$ Skin surface area $\left[19,400\right.$ square centimeters $\left.\left(\mathrm{cm}^{2}\right)\right]$.
$\mathrm{Pc}=$ Dermal permeability constant $(0.001 \mathrm{~cm} /$ hour $)$.
$\mathrm{Cf}=$ Conversion factor $\left(0.001 \mathrm{~L} / \mathrm{cm}^{3}\right)$.
ET = Exposure time (0.2 hour/day).

apicocuries per lifetime.

buranium-234 and uranium-238 combined. 
Table 4.2 Exposure dose calculations and equation definitions for groundwater-irrigated garden produce ingestion, Gunnison UMTRA Project site, Gunnison, Colorado

\begin{tabular}{|c|c|c|c|c|c|c|}
\hline $\begin{array}{c}\text { Contaminant of } \\
\text { concern }\end{array}$ & $\begin{array}{c}C w \\
(m g / L)\end{array}$ & $\begin{array}{c}\text { Kd } \\
\text { (L/kg) }\end{array}$ & Bv & Br & $\begin{array}{l}\text { Garden produce } \\
\text { ingestion } \\
\text { exposure doses } \\
\text { (mg/kg/day) }\end{array}$ & $\begin{array}{c}\text { Ratio of } \\
\text { produce ingestion: } \\
\text { water ingestion }\end{array}$ \\
\hline \multicolumn{7}{|l|}{ Noncancer offects } \\
\hline Cadmium & 0.004 & 15 & 0.55 & 0.15 & 2E-06 & 0.02 \\
\hline Cobalt & 0.37 & 1.9 & 0.02 & 0.007 & $8 E-07$ & 0.00008 \\
\hline Iron & 91 & 15 & 0.004 & 0.001 & 3E-04 & 0.0001 \\
\hline Manganese & 39 & 17 & 0.25 & 0.05 & $2 E-03$ & 0.0002 \\
\hline Sulfate & 1590 & 0 & 0.5 & 0.5 &.. b & -. \\
\hline Uranium & 1.6 & 1 & 0.0085 & 0.004 & $8 E-07$ & 0.00002 \\
\hline Cencer effects & (pCi/L) & & & & & \\
\hline Lead-210 & 78 & 230 & 0.045 & 0.009 & $3 E+04^{c}$ & 0.02 \\
\hline Polonium-210 & 1.6 & 5.9 & 0.025 & 0.0004 & $8 \mathrm{E}+00^{c}$ & 0.0003 \\
\hline Thorium-230 & 2.0 & 100 & 0.00085 & 0.000085 & $6 E+00^{C}$ & 0.0002 \\
\hline Uranium & 1100 & 1 & 0.0085 & 0.004 & $4 E+02^{c}$ & 0.00002 \\
\hline
\end{tabular}

\section{Equation definitions for exposure dose calculations}

Ingestion of garden produce irrigated with groundwater - carcinogens and noncarcinogens:

Chronic daily intake $(\mathrm{mg} / \mathrm{kg} / \mathrm{day})$

Radionuclides (pCi)

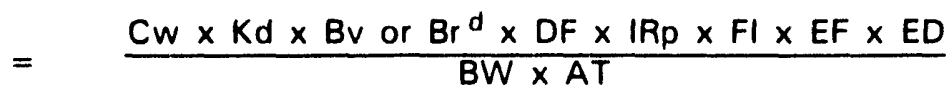

$=\quad \mathrm{Cw} \times \mathrm{Kd} \times \mathrm{Bv}$ or $\mathrm{Br}^{d} \times \mathrm{DF} \times \operatorname{RRp} \times \mathrm{FI} \times \mathrm{EF} \times \mathrm{ED}$

Where:

$\mathrm{CW}_{\mathrm{w}}=$ Contaminant concentration in groundwater (maximum concentration detected) $(\mathrm{mg} / \mathrm{L}$ or $\mathrm{pCi} / \mathrm{Ll}$.

Kd = Soil-water partition coefficient (L/kg); from Pacific Northwest Laboratory (PNL), 1989, except for uranium. The Kd for uranium is a site-specific value.

$\mathrm{Bv}=$ Soil-to-plant concentration ratio for vegetative portions of plants (unitless).

$\mathrm{Br}=$ Soil-to-plant concentration ratio for reproductive portions (fruits, tubers) of plants (unitless).

$D F=$ Dry weight fraction of plant $(0.066$ unitless).

$\operatorname{IRp}=$ Ingestion rate for garden produce $10.05 \mathrm{~kg} / \mathrm{day}$ for vegetative parts; $0.03 \mathrm{~kg} / \mathrm{day}$ for reproductive parts).

$\mathrm{FI}=$ Fraction of garden produce ingested from contaminated source (1.0 unitless).

$E F=$ Exposure frequency (350 days/year).

$E D=$ Exposure duration ( 30 years for an adult).

$B W=$ Body weight $(70 \mathrm{~kg}$ for an adult $)$.

AT $=$ Averaging time ( 365 days $\times$ ED for noncarcinogens).

${ }^{a}$ Exposure doses shown are the sum of the vegetative parts plus the reproductive parts.

b Value cannot be calculated because $K d$ is equal to zero.

cPicocuries per lifetime.

${ }^{d}$ Exposure doses due to vegetative parts and reproductive parts of garden produce are calculated separately, then summed for total intake. 


\subsubsection{Ingestion of milk or meat from groundwater-fed livestock}

The relative contribution from ingestion of milk from groundwater-fed livestock is 4 percent or less for all constituents (Table 4.3). Ingestion of meat from these animals would also contribute 4 percent or less of the exposure anticipated from drinking water for all constituents (Table 4.4). The contribution from these sources is not included in the exposure simulations, but the impact of these additional sources is discussed in Sections 6.1 and 6.2.

\subsubsection{Ingestion of fish}

Sportfishing occurs in the reaches of the Gunnison River and Tomichi Creek in the vicinity of the site. Trout fishing also occurs in the stocked campground pond. Ingestion of fish that may have accumulated site-related constituents is a potential exposure pathway. Hook-and-line fishing was conducted at two locations in the Gunnison River (locations 775 and 776), and at one location in both Tomichi Creek (location 777) and the campground pond (location 779) (see Figure 3.11). The filleted muscle tissue was submitted to the laboratory and analyzed for manganese, molybdenum, uranium, and zinc. This list was formulated prior to conducting this risk assessment and was based on a screening of maximum detected concentrations in groundwater. The results from the muscle tissue analyses are presented in Table 4.5.

Manganese was detected at the highest concentration $(3.8 \mathrm{mg} / \mathrm{kg})$ in the fish collected from the upstream Gunnison River location. The concentrations in fish from the other locations ranged from $1.1 \mathrm{mg} / \mathrm{kg}$ (campground pond) to $1.9 \mathrm{mg} / \mathrm{kg}$ (downstream locations in both the river and creek). Molybdenum was detected only in the fish collected at the upstream Gunnison River location. Uranium was detected at a concentration of $0.46 \mathrm{mg} / \mathrm{kg}$ in fish tissue from the downstream Gunnison River location. Uranium was not detected $(<0.2 \mathrm{mg} / \mathrm{kg})$ in fish from the other sampling locations. Zinc was detected at similar concentrations in fish tissue from all the sampling locations; the concentrations ranged from $24 \mathrm{mg} / \mathrm{kg}$ to 28.4 $\mathrm{mg} / \mathrm{kg}$.

To evaluate the fish ingestion exposure route, a screening calculation was performed to determine if the contribution from fish ingestion from each location tested would be significant compared to the drinking water pathway. For the purposes of this screening pathway, if the constituent was not detected in a sample, then one-half the detection limit was used to represent the exposure point concentration.

The results of the screening are given in Table 4.6. Based on the manganese and uranium results, the fish ingestion exposure route is eliminated from more detailed evaluation, since it contributed to less than 1 percent of the total dose from drinking water. The maximum ingestion doses calculated for zinc and molybdenum are within nutritional ranges. 
Table 4.3 Exposure dose calculations and equation definitions for ingestion of milk from groundwater-fed livestock, Gunnison UMTRA Project site, Gunnison, Colorado

\begin{tabular}{|c|c|c|c|c|c|c|c|}
\hline $\begin{array}{c}\text { Contaminant of } \\
\text { concern }\end{array}$ & $\begin{array}{c}C w \\
(m g / L)\end{array}$ & & $\begin{array}{c}\text { Kd } \\
\text { (L/kg) }\end{array}$ & Bv & Fm & $\begin{array}{l}\text { Milk ingestion } \\
\text { exposure doses } \\
\text { (mg/kg/day) }\end{array}$ & $\begin{array}{l}\text { Ratio of } \\
\text { milk ingestion: } \\
\text { water ingestion }\end{array}$ \\
\hline \multicolumn{8}{|l|}{ Noncancer offects } \\
\hline Cadmium & 0.004 & & 15 & 0.55 & 0.001 & 4E.06 & 0.04 \\
\hline Cobalt & 0.37 & & 1.9 & 0.02 & 0.002 & $2 E-04$ & 0.02 \\
\hline Iron & 91 & , & 15 & 0.004 & 0.00025 & $6 E-03$ & 0.002 \\
\hline Manganese & 39 & & 17 & 0.25 & 0.00035 & $1 E-03$ & 0.001 \\
\hline Sulfate & 1590 & & 0 & 0.5 & 0.005 &.$- \mathbf{a}$ & -. \\
\hline Uranium & 1.6 & & 1 & 0.0085 & 0.0006 & $2 E-04$ & 0.005 \\
\hline Cancer effects & $(p C i / L)$ & & & & & & \\
\hline Lead-210 & 78 & & 230 & 0.045 & 0.00025 & $2 E+04^{b}$ & 0.01 \\
\hline Polonium-210 & 1.6 & & 5.9 & 0.025 & 0.00035 & $1 E+02^{b}$ & 0.003 \\
\hline Thorium-230 & 2.0 & & 100 & 0.00085 & 0.000005 & $3 E+00^{b}$ & 0.00008 \\
\hline Uranium & 1100 & & 1 & 0.0085 & 0.0006 & $1 E+05^{b}$ & 0.005 \\
\hline
\end{tabular}

Equation definitions for exposure dose calculations

Ingestion of milk from groundwater-fed livestock - carcinogens and noncarcinogens:
Chronic daily intake $(\mathrm{mg} / \mathrm{kg} /$ day)
$\mathrm{Cm} \times \mid \mathrm{Rm} \times \mathrm{FI} \times \mathrm{EF} \times \mathrm{ED}$
Radionuclides (pCi)
$=\quad \mathrm{Cm} \times \mathrm{IRm} \times \mathrm{FI} \times \mathrm{EF} \times \mathrm{ED}$

Where:
$\mathrm{Cm}=$ Contaminant concentration in milk $(\mathrm{mg} / \mathrm{L})$, estimated using the following equation: $\mathrm{Cm}=\mathrm{Fm} \times(|\mathrm{Qp} \times \mathrm{Cp}|+[\mathrm{Q} \times \mathrm{Cs}]+[\mathrm{Qw} \times \mathrm{Cw}])$
$\mathrm{Fm}=$ Feed-to-milk transfer coefficient (days $/ \mathrm{kg}$ ).
$Q_{p}=$ The quantity of pasture eaten by cattle per day $(19 \mathrm{~kg} / \mathrm{day})$.
Qs = The quantity of soil eaten by cattle per day $(0.38 \mathrm{~kg} /$ day $)$.
$\mathrm{Qw}=$ The quantity of water consumed by cattle per day $(56 \mathrm{~L} /$ day $)$.
$\mathrm{Cp}=$ Contaminant concentration in pasture $(\mathrm{mg} / \mathrm{kg}) . \quad \mathrm{Cp}=\mathrm{Kd} \times \mathrm{CW} \times \mathrm{Bv}$.
$C s=$ Contaminant concentration in soil $(\mathrm{mg} / \mathrm{kg})$. Cs $=\mathrm{Kd} \times \mathrm{CW}$.
$\mathrm{Cw}=$ Contaminant concentration in groundwater (maximum concentration detected) (mg/L or pCi/L).
Kd = Soil-water partition coefficient $(\mathrm{L} / \mathrm{kg})$; from PNL, 1989, except for uranium. The Kd for uranium is a site-specific value.
$\mathrm{Bv}=$ Soil-to-plant concentration ratio for vegetative portions of plants (unitless).
$\mathrm{EF}=$ Exposure frequency ( 350 days/year).
$E D=$ Exposure duration ( 30 years for an adult).
$B W=$ Body weight $(70 \mathrm{~kg}$ for an adult).
$A T=$ Averaging time (365 days $\times E D$ for noncarcinogens).
$\mathbb{I R m}=$ Ingestion rate of milk $10.3 \mathrm{~kg} /$ day $)$.
$\mathrm{FI}=$ Fraction of milk ingested from contaminated source (1.0 unitless).

a Value cannot be calc. lated because $\mathrm{Kd}$ is equal to zero.

bicocuries per lifetime. 
Table 4.4 Exposure dose calculations and equation definitions for ingestion of meat from groundwater-fed livestock, Gunnison UMTRA Project site, Gunnison, Colorado

\begin{tabular}{|c|c|c|c|c|c|c|}
\hline $\begin{array}{c}\text { Contaminant of } \\
\text { concern }\end{array}$ & $\begin{array}{c}C w \\
(m g / L)\end{array}$ & $\begin{array}{c}K d \\
(L / k g)\end{array}$ & Bv & $\mathbf{F f}$ & $\begin{array}{l}\text { Meat ingestion } \\
\text { exposure doses } \\
\text { (mg/kg/day) }\end{array}$ & $\begin{array}{c}\text { Ratio of } \\
\text { meat ingestion: } \\
\text { water ingestion }\end{array}$ \\
\hline \multicolumn{7}{|l|}{ Noncancer effects } \\
\hline Cadmium & 0.004 & 15 & 0.55 & 0.00055 & 5E-07 & 0.005 \\
\hline Cobalt & 0.37 & 1.9 & 0.02 & 0.02 & 4E.04 & 0.04 \\
\hline Iron & 91 & 15 & 0.004 & 0.02 & $1 E-01$ & 0.03 \\
\hline Manganese & 39 & 17 & 0.25 & 0.0004 & $4 E-04$ & 0.0004 \\
\hline Sulfate & 1590 & 0 & 0.5 & 0.005 &.$^{a}$ & -. \\
\hline Uranium & 1.6 & 1 & 0.0085 & 0.0002 & $2 \mathrm{E}-05$ & 0.0005 \\
\hline Cancer effects & $(\mathrm{pCi} / \mathrm{L})$ & & & & & \\
\hline Lead-210 & 78 & 230 & 0.045 & 0.0003 & $6 E+03^{b}$ & 0.003 \\
\hline Polonium-210 & 1.6 & 5.9 & 0.025 & 0.0003 & $2 E+01^{b}$ & 0.0007 \\
\hline Thorium-230 & 2.0 & 100 & 0.00085 & 0.000006 & $9 E-01^{b}$ & 0.00002 \\
\hline Uranium & 1100 & 1 & 0.0085 & 0.0002 & $1 E+04^{b}$ & 0.0005 \\
\hline
\end{tabular}

\section{Equation definitions for exposure dose calculations}

Ingestion of meat from groundwater-fed livestock - carcinogens and noncarcinogens:

$\begin{array}{ll}\text { Chronic daily intake }(\mathrm{mg} / \mathrm{kg} / \mathrm{day}) & =\frac{\mathrm{Cb} \times \mathrm{RB} \times \mathrm{FI} \times \mathrm{EF} \times \mathrm{ED}}{\mathrm{BW} \times \mathrm{AT}} \\ \text { Radionuclides }(\mathrm{pCi}) & =\mathrm{Cb} \times \mathrm{Rb} \times \mathrm{FI} \times \mathrm{EF} \times \mathrm{ED}\end{array}$

Where:
$\mathrm{Cb}=$ Contaminant concentration in beef $(\mathrm{mg} / \mathrm{kg})$, estimated using the following equation: $\mathrm{Cb}=\mathrm{Ff} \times([\mathrm{Qp} \times \mathrm{Cp}]+[\mathrm{Qs} \times \mathrm{Cs}]+[\mathrm{Qw} \times \mathrm{Cw}])$ where
$\mathrm{Ff}=$ Feed-to-flesh transfer coefficient (days $/ \mathrm{kg}$ ).
$\mathrm{Q}_{p}=$ The quantity of pasture eaten by cattle per day $(19 \mathrm{~kg} / \mathrm{day})$.
Qs $=$ The quantity of soil eaten by cattle per day $(0.38 \mathrm{~kg} / \mathrm{day})$.
$\mathrm{Q} w=$ The quantity of water consumed by cattle per day (56 L./day).
$\mathrm{Cp}=$ Contaminant concentration in pasture $(\mathrm{mg} / \mathrm{kg}) . \mathrm{Cp}_{p}=\mathrm{Kd} \times \mathrm{CW} \times \mathrm{Bv}$.
$\mathrm{Cs}=$ Contaminant concentration in soil $(\mathrm{mg} / \mathrm{kg})$. Cs $=\mathrm{Kd} \times \mathrm{CW}$.
$\mathrm{C}_{w}=$ Contaminant concentration in groundwater (maximum concentration detected) (mg/L or $\mathrm{pCi} / \mathrm{L})$.
$K d=$ Soil-water partition coefficient (L/kg); from PNL, 1989, except for uranium. The Kd for uranium is a site-specific value.
Bv = Soil-to-plant concentration ratio for vegetative portions of plants (unitless).
$\mathrm{EF}=$ Exposure frequency (350 days/year).
$E D=$ Exposure duration ( 30 years for an adult).
$\mathrm{BW}=$ Body weight $(70 \mathrm{~kg}$ for an adult).
AT $=$ Averaging time (365 days $\times$ ED for noncarcinogens).
$\mid R b=$ Ingestion rate of meat $(0.075 \mathrm{~kg} /$ day $)$.
$\mathrm{FI}=$ Fraction of meat ingested from contaminated source (1.0 unitless).

\footnotetext{
${ }^{a}$ Value cannot be calculated because $\mathrm{Kd}$ is equal to zero.

bicocuries per lifetime.
} 
Table 4.5 Constituents in muscle tissue of fish collected from surface water bodies located in the site vicinity, Gunnison UMTRA Project site, Gunnison, Colorado

\begin{tabular}{|c|c|c|c|c|}
\hline \multirow[b]{2}{*}{ Constituent } & \multicolumn{2}{|c|}{$\frac{\text { Gunnison River }}{\text { Location ID }}$} & \multirow{2}{*}{$\begin{array}{c}\frac{\text { Tomichi Creek }}{\text { Location ID }} \\
777 \\
\text { (Downstream) }\end{array}$} & \multirow{2}{*}{$\begin{array}{c}\text { Campground pond } \\
\text { Location ID } \\
779\end{array}$} \\
\hline & $\begin{array}{c}775 \\
\text { (Upstream) }\end{array}$ & $\begin{array}{c}776 \\
\text { (Downstream) }\end{array}$ & & \\
\hline Manganese & 3.8 & 1.9 & 1.9 & 1.1 \\
\hline Molybdenum & 0.26 & $<0.20$ & $<0.20$ & $<0.20$ \\
\hline Uranium & $<0.20$ & 0.46 & $<0.20$ & $<0.20$ \\
\hline Zinc & 28.1 & 24 & 28.4 & 26.6 \\
\hline
\end{tabular}

All concentrations reported in milligrams per kilogram dry weight (DW).

\section{Summary}

In summary, the results from all of the screening pathways (water ingestion; dermal contact with water; milk, meat, and fish ingestion) indicate drinking water ingestion is the dominant pathway; as slich, this pathway is further evaluated probabilistically in Section 4.4 .

\subsection{EXPOSURE CONCENTRATIONS}

The exposure concentration of a contaminant in groundwater is defined as the concentration an individual is assumed to take in over a specific period. In this evaluation, the contaminant conccntrations are assumed to be in a steady state, although actual contaminant concentrations (and therefore exposures) are expected to decrease with time after the tailings are removed. Nonetheless, these estimates are reasonable for chronic exposure soon after surface remediation. Chronic exposure for noncarcinogens is considered to be exposure for any period longer than 7 years.

For noncarcinogens, exposure concentrations are evaluated as a probability of occurrence based on groundwater data collected from monitor wells 006, 133, and 134 for the contaminants of potential concern. These wells have consistently shown the highest concentrations of most contaminants since 1989. As discussed in Section 3.4, concentrations of manganese are greatest in the deeper wells downgradient from the tailings pile; therefore, monitor wells 106, 109, 110, 111, and 112 were used to evaluate potential manganese exposures. All of these wells are located on the processing site.

The probability distribution selected for each contaminant reflected the same mean, median, standard deviation, and shape observed in historical water quality data. 


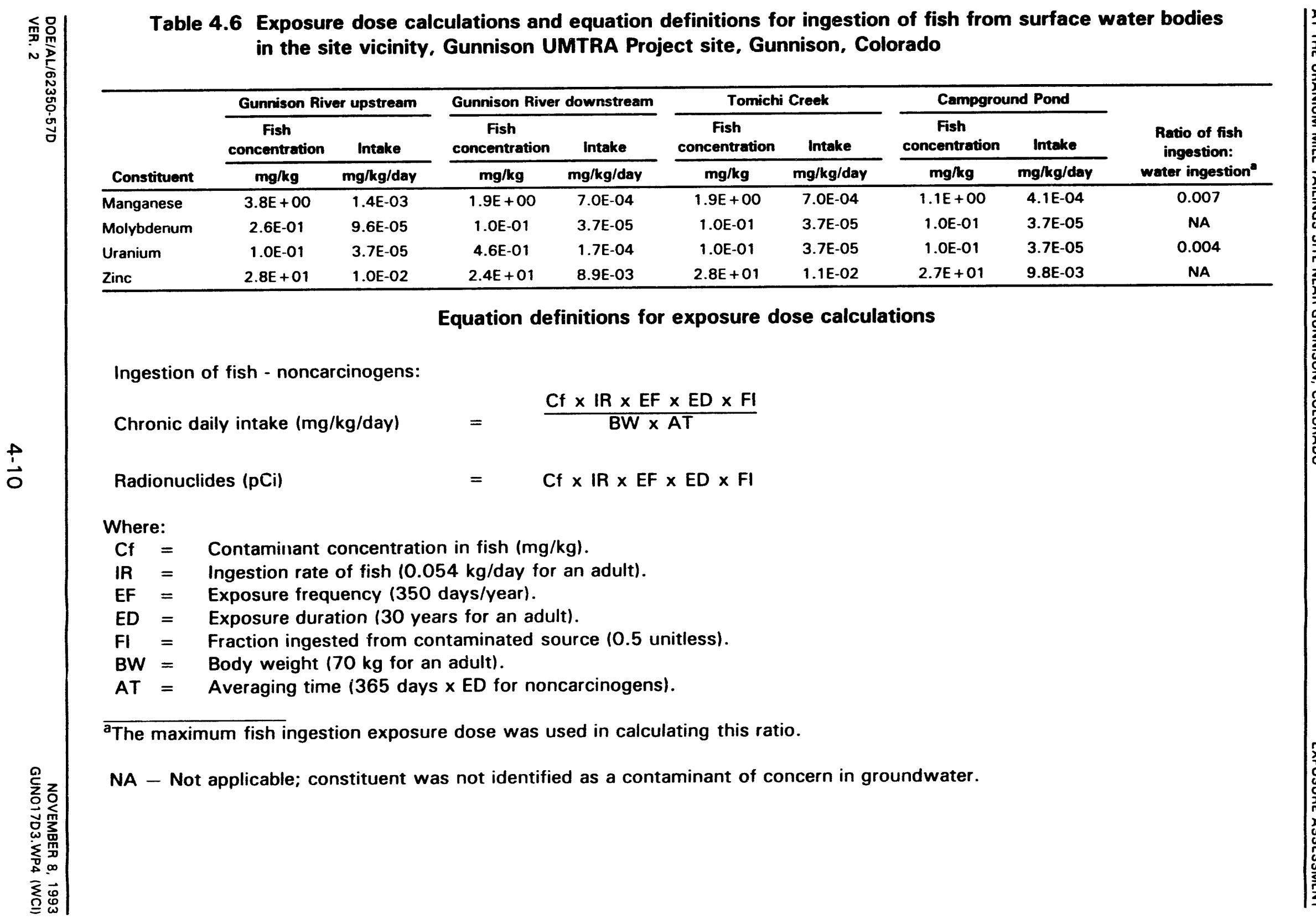


The upper tail of the distributions was truncated at the 99th percentile. For every contaminant, this highest allowable concentration was higher than the maximum observed concentration in the historical water quality data. The software package @RISK (Palisade Corporation, 1992) was used to generate the probability curves for the contaminants of potential concern. The results are shown in Figures 4.2 through 4.7.

The concentrations of radionuclides were represented by the median and maximum values observed in wells 006, 133, and 134.

\subsection{ESTIMATION OF INTAKE}

Within the population of future residents, individuals are expected to vary with respect to water consumption habits, stable body weight, and length of time they reside in the potential contamination zone. Consequently, health risks associated with groundwater consumption will vary among members of this population. To adequately describe the range of potential risks to the future population, naturally occurring variability in daily water intake, body weight, and residency time were incorporated in this assessment through probability distributions; these distributions were generated from United States public health and census documents. All distributions were truncated at the upper and lower 0.01 percentile. Within the hypothetical population, values disallowed through this truncation may occur with a probability of less than 1 in 10,000.

The potential toxicity of noncarcinogenic contaminants in drinking water depends primarily on long-term average daily consumption of the contaminant per kilogram of body weight. For probability distributions of noncarcinogens, exposure frequency multiplied by exposure duration cancels out with averaging time. Therefore, these factors are omitted from the equation and chronic daily intake is calculated as follows:

$$
\text { Intake }(\mathrm{mg} / \mathrm{kg} / \mathrm{day})=\frac{\text { Concentration }(\mathrm{mg} / \mathrm{L}) \times \text { ingestion rate }(\mathrm{L} / \text { day) }}{\text { Body weight }(\mathrm{kg})}
$$

Potential carcinogenicity is thought to increase with total intake over time, instead of with average daily intake as for noncarcinogens. Also, body weight is relatively insignificant in determining risk from exposure. The only carcinogens elevated above background at the Gunnison site are the radionuclides lead-210, polonium-210, thorium-203, and uranium. Therefore, only calculations for radioactive carcinogens will be presented here. Intake of a carcinogenic substance is therefore quantified as total exposure to radioactivity throughout the residency period of an individual:

$$
\underset{(p C i)}{\text { Intake }}=\underset{(p C i / L)}{\text { Concentration }} \times \underset{\text { iL/day })}{\text { ingestion rate }} \times \underset{\text { (days) }}{x}
$$




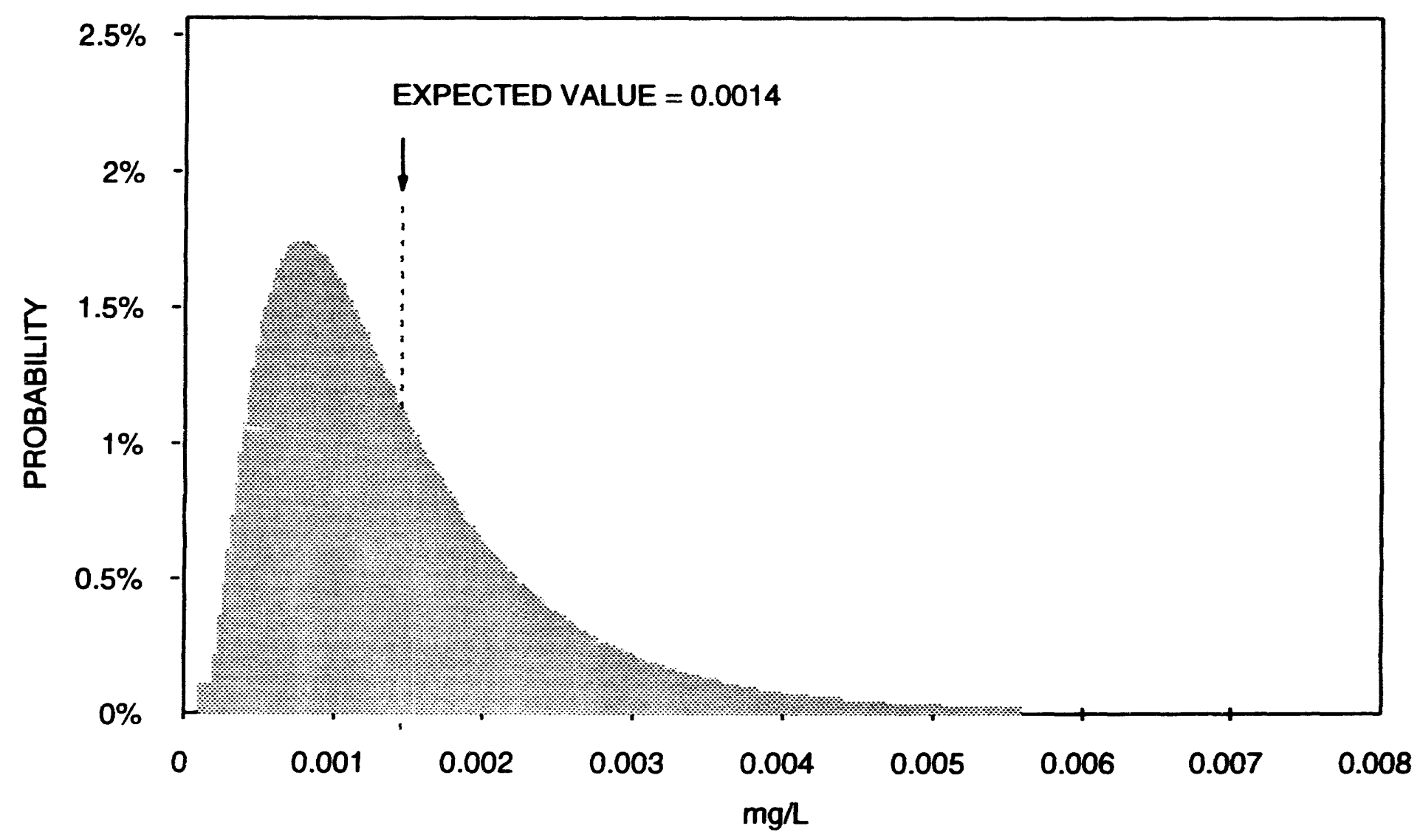

FIGURE 4.2

SIMULATED DISTRIBUTION OF CADMIUM CONCENTRATIONS

GUNNISON, COLORADO, STE 


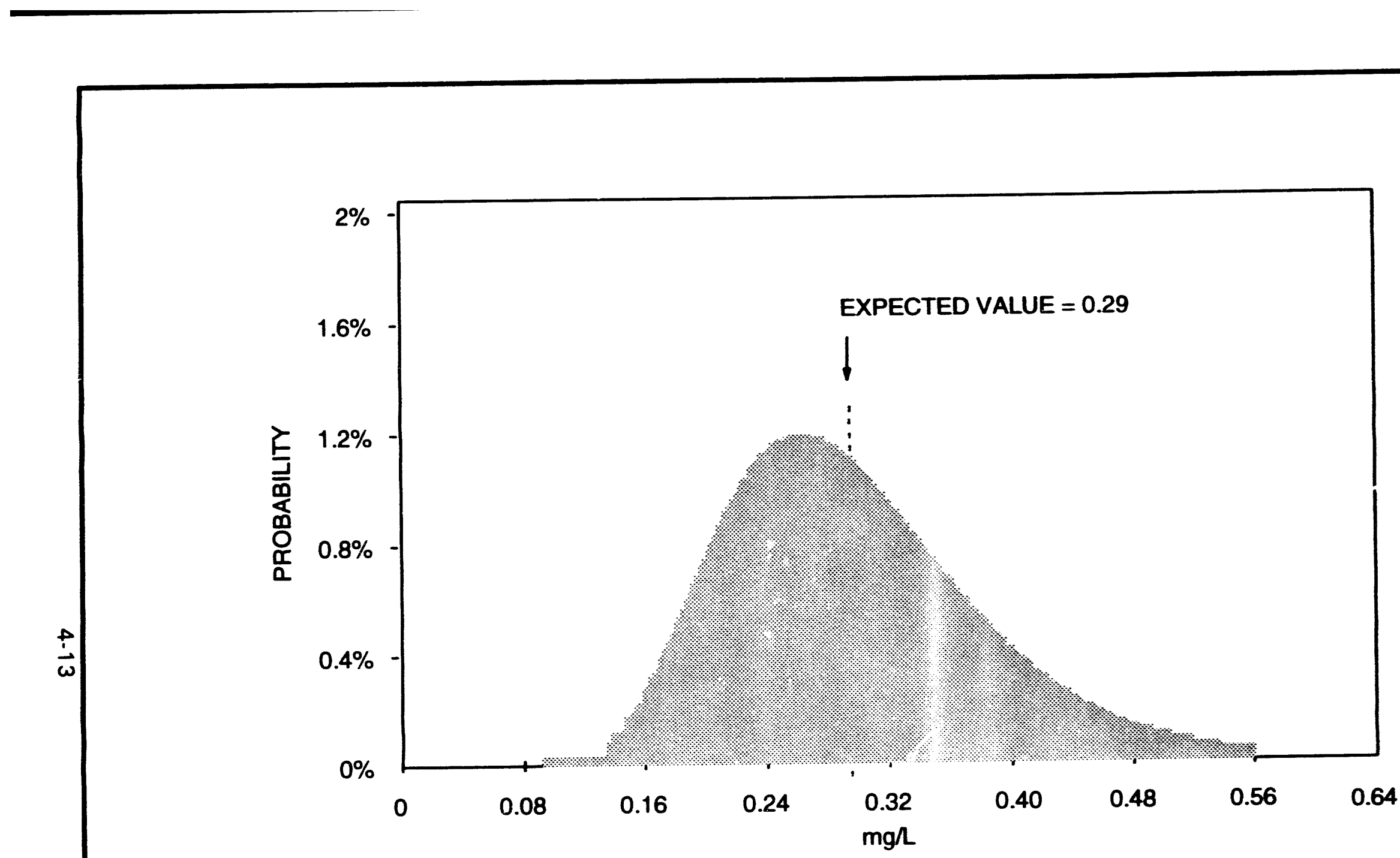

FIGURE 4.3

SIMULATED DISTRIBUTION OF COBALT CONCENTRATIONS GUNNISON, COLORADO, SITE

PATH ITAL 3.01GUNBRA

Destracos.ofm 


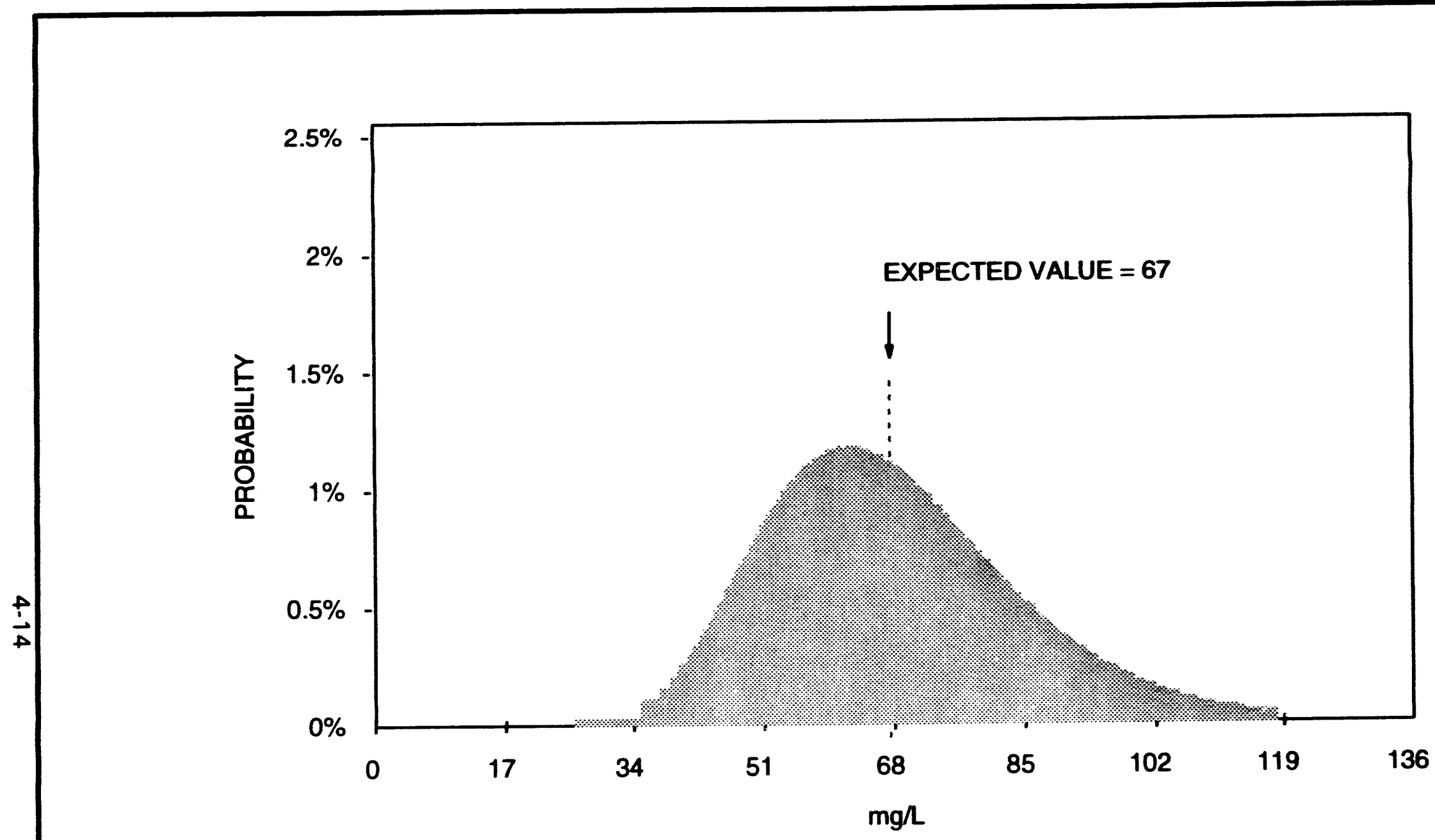

FIGURE 4.4

SIMULATED DISTRIBUTION OF IRON CONCENTRATIONS

GUNNISON, COLORADO, STTE 


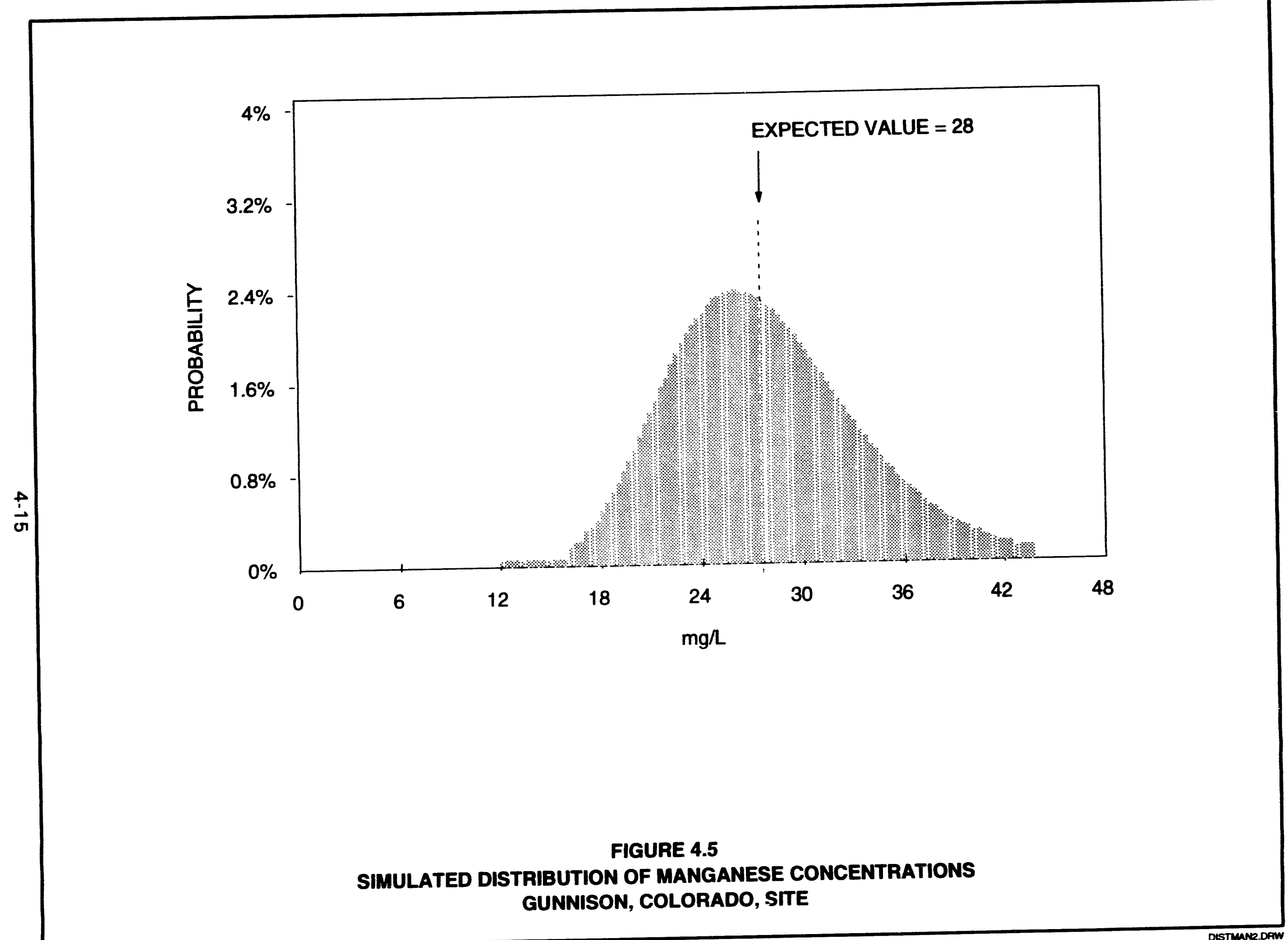




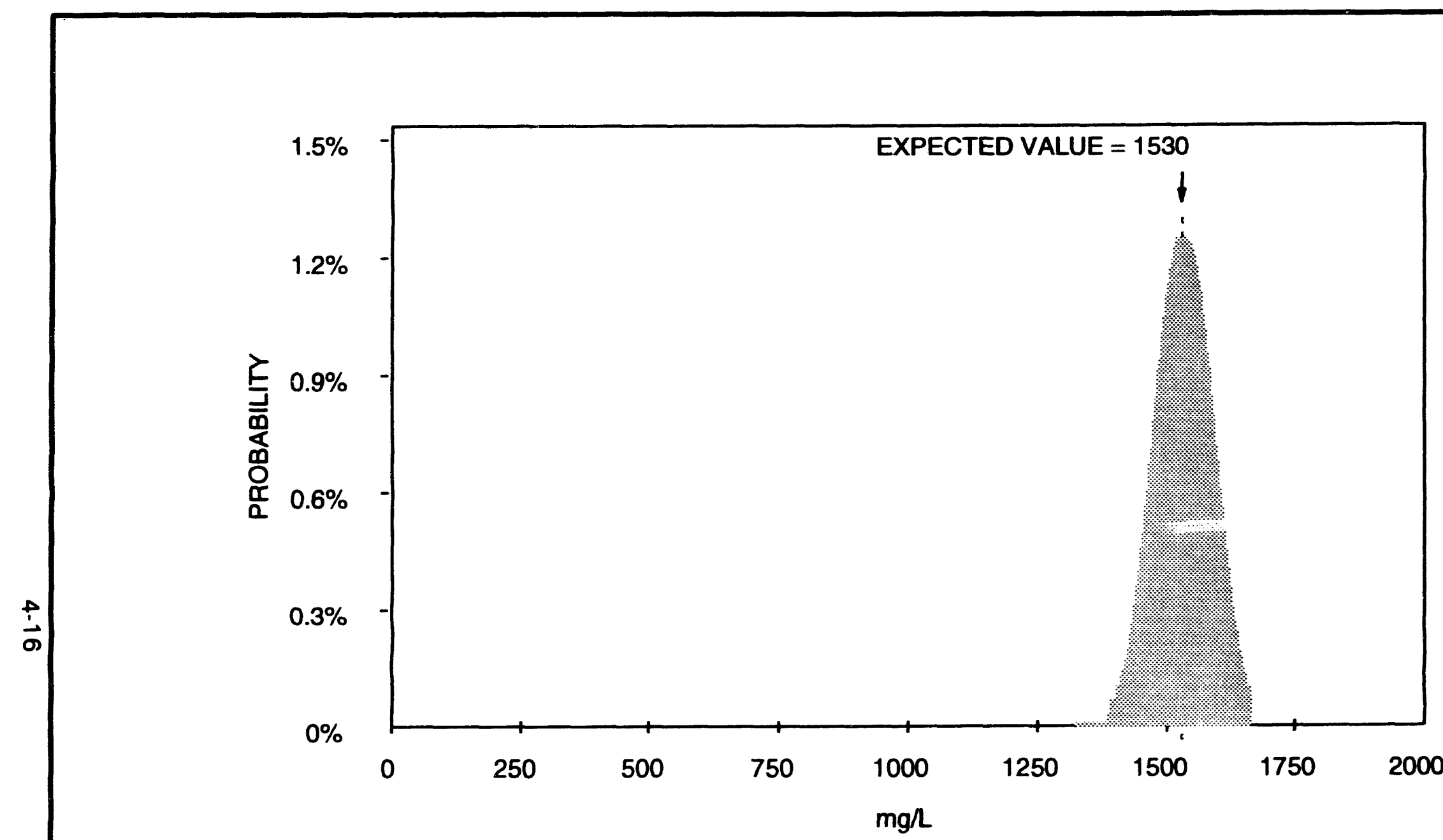

FIGURE 4.6

SIMULATED DISTRIBUTION OF SULFATE CONCENTRATIONS GUNNISON, COLORADO, STTE 


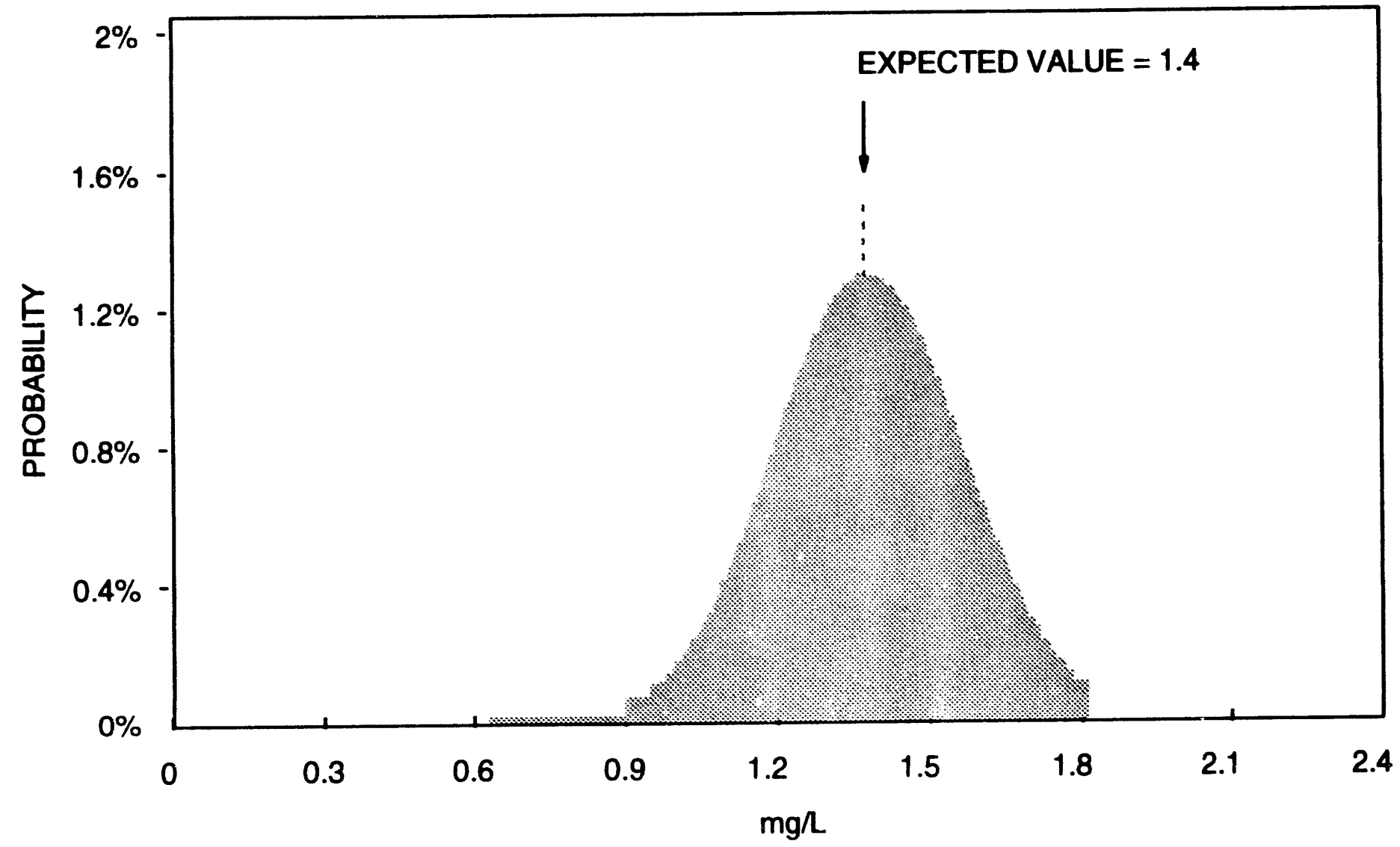

FIGURE 4.7

SIMULATED DISTRIBUTION OF URANIUM CONCENTRATIONS

GUNNISON, COLORADO, SITE 


\section{Average daily intake (L/day)}

Lognormal probability distributions were used to describe variation in average daily tap water intake among members of the population (Roseberry and Burmaster, 1992). These distributions were developed from data collected during the 1977-78 National Food Consumption Survey conducted by the U.S. Department of Agriculture. During the survey, total tap water consumption during a 3-day period was recorded for 26,081 survey participants nationwide (Figure 4.8).

\section{Body weight $(\mathbf{k g})$}

Extensive national data on weights of males and females, by age, were collected by the National Health and Nutrition Survey between 1976 and 1980. These data were used to develop lognormal probability distributions for body weight by age, separately by sex. The distributions for males and temales were then combined using census data on the national ratio of males to females within each age group (Figure 4.9).

\section{Exposure duration (vears)}

A survey of residents in the Dos Rios area indicated that residency time frequently exceeded 25 years (DOE, 1990). Therefore, a fixed lifetime exposure time of 30 years was used to model lifetime cancer risks. Because the concentrations of radionuclides in groundwater at the Gunnison site are decreasing with time, evaluations of risk based on this exposure duration in combination with historic and current median and maximum concentrations of radionuclides should yield conservative estimates of carcinogenic risks for this site.

Using exposure concentration distributions discussed in Section 4.3 and the intake parameter distributions described in this section, total intake distributions derived for the three age groups were generated for uranium. These results are presented in Figure 4.10 to illustrate the effect of the different age group characterization on daily intake of noncarcinogens. From this figure, it can be seen that intake is greatest in the 1-to 10-year age group, although the intake for the 0 - to 1-year age group is very similar. Therefore, the 1 - to 10 -year age group is used in risk evaluation unless one of the other age groups has demonstrated increased sensitivity to a particular constituent. No data are available to evaluate any sensitive subpopulations for any of the contaminants of concern at the Gunnison site. Therefore, simulated intake distributions for 1-to 10-year old children for the contaminants at this site are presented in Figures 4.11 through 4.15. 

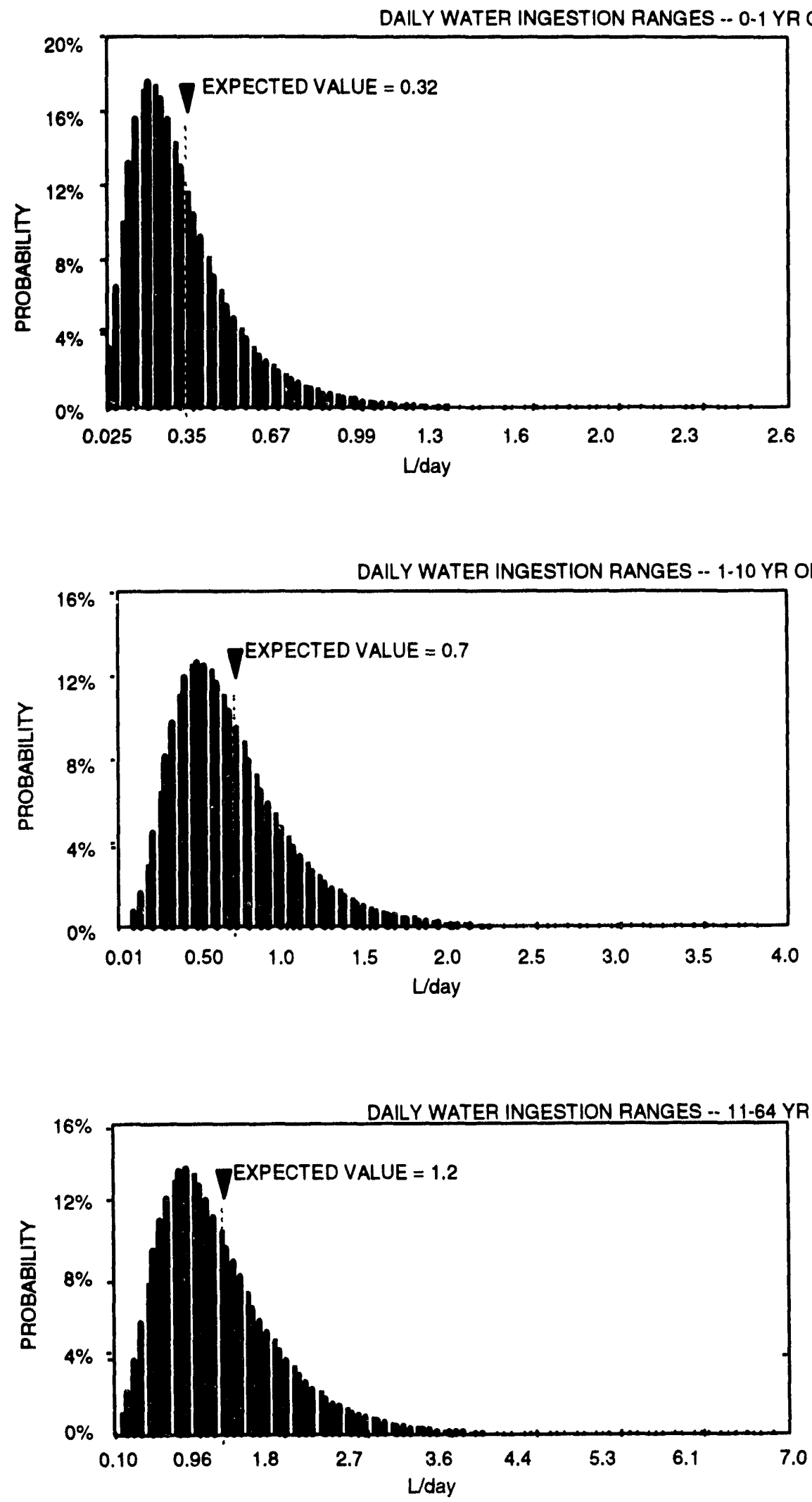

FIGURE 4.8

PROBABILITY DISTRIBUTIONS FOR TAP WATER INGESTION RATES 


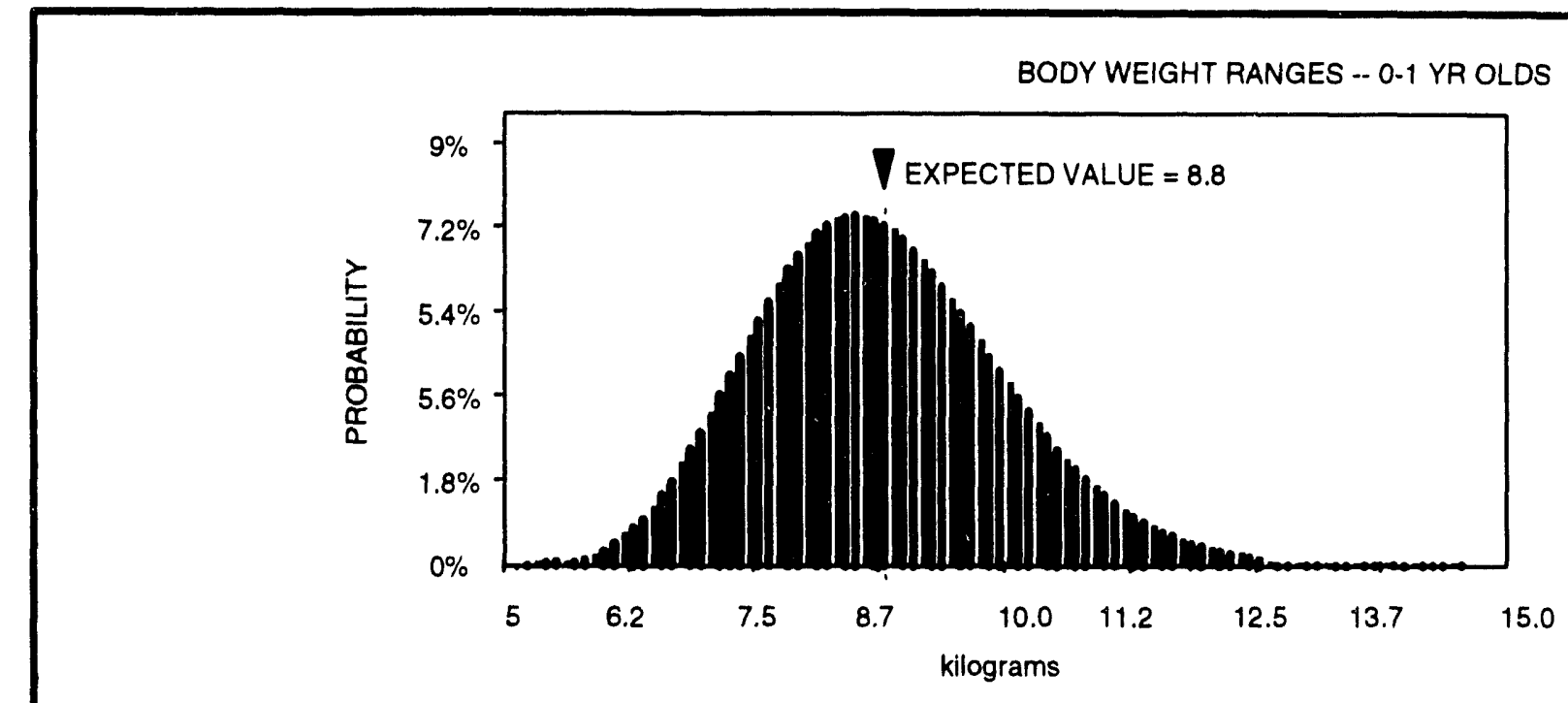

BODY WEIGHT RANGES .. 1-10 YR OLDS

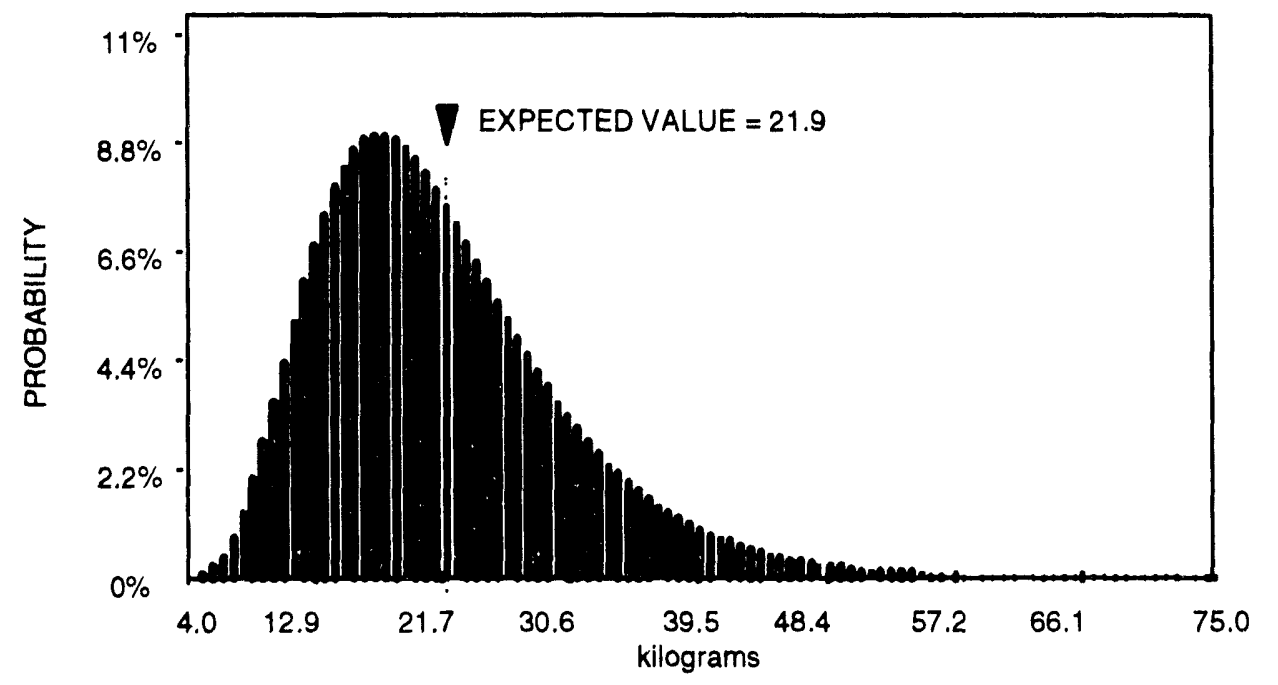

BODY WEIGHT RANGES -- 11-64 YR OLDS

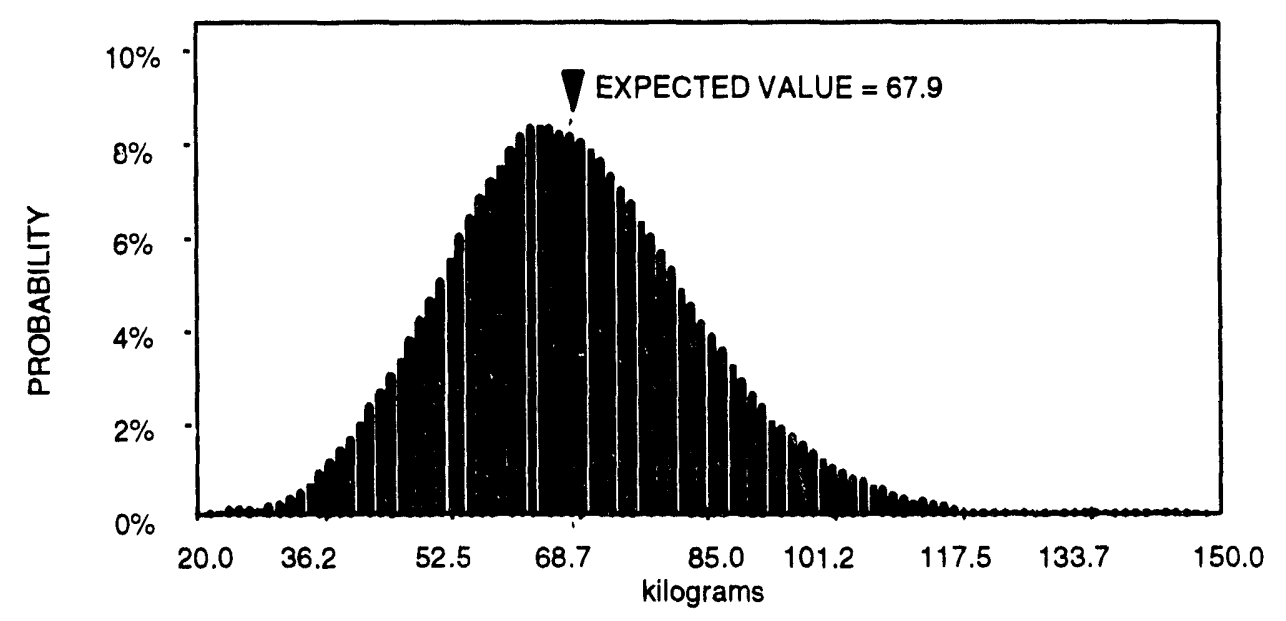

FIGURE 4.9

PROBABILITY DISTRIBUTIONS FOR BODY WEIGHT 

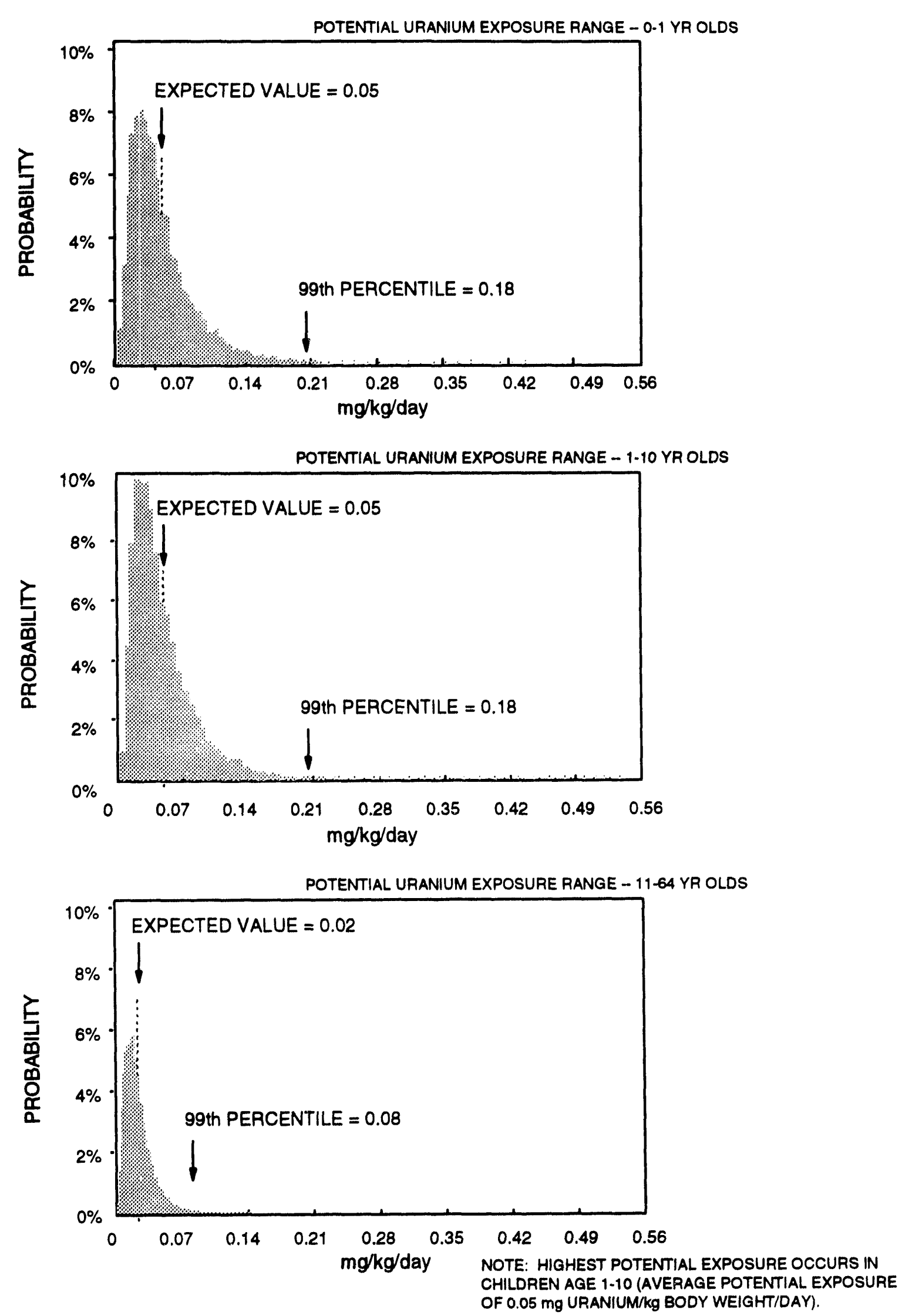

FIGURE 4.10

COMPARISON OF DISTRIBUTIONS OF POTENTIAL URANIUM EXPOSURES AS A RESULT OF DRINKING CONTAMINATED GROUNDWATER FOR THE THREE AGE GROUPS EXAMINED GUNNISON, COLORADO, SITE 


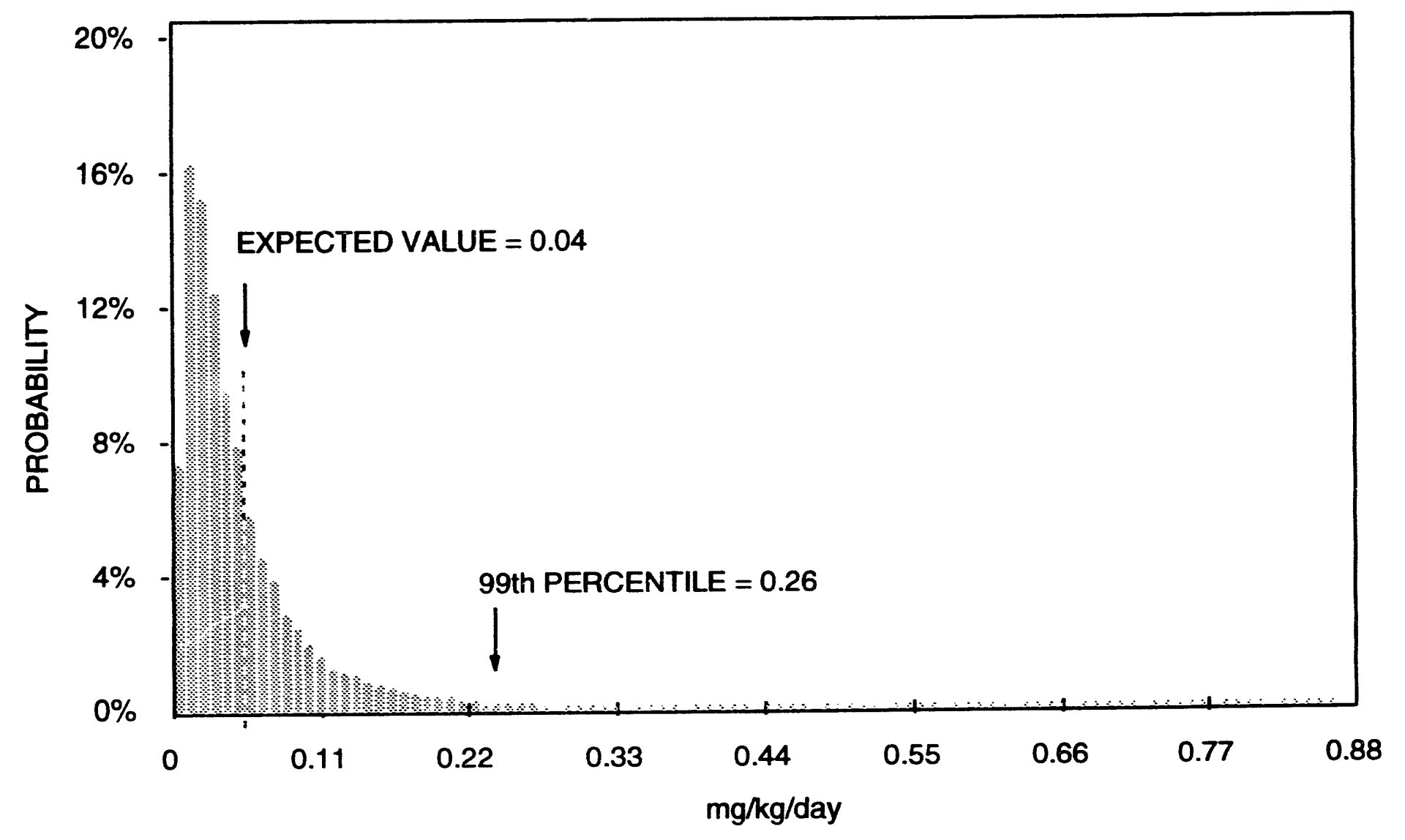

NOTE: AVERAGE POTENTIAL EXPOSURE IS $0.04 \mathrm{mg}$ CADMIUM/kg BODY WEIGHTIOAY. EXPOSURES FOR CHILDREN HAVE BEEN MODELED BECAUSE THEIR INTAKE/kg BODY WEIGHT IS GREATEST AND NO SENSITIVE POPULATION HAS BEEN IDENTIFIED.

FIGURE 4.11

DISTRIBUTION OF POTENTIAL CADMIUM EXPOSURES FOR CHILDREN AS A RESULT OF GROUNDWATER INGESTION

GUNNISON, COLORADO, STTE 


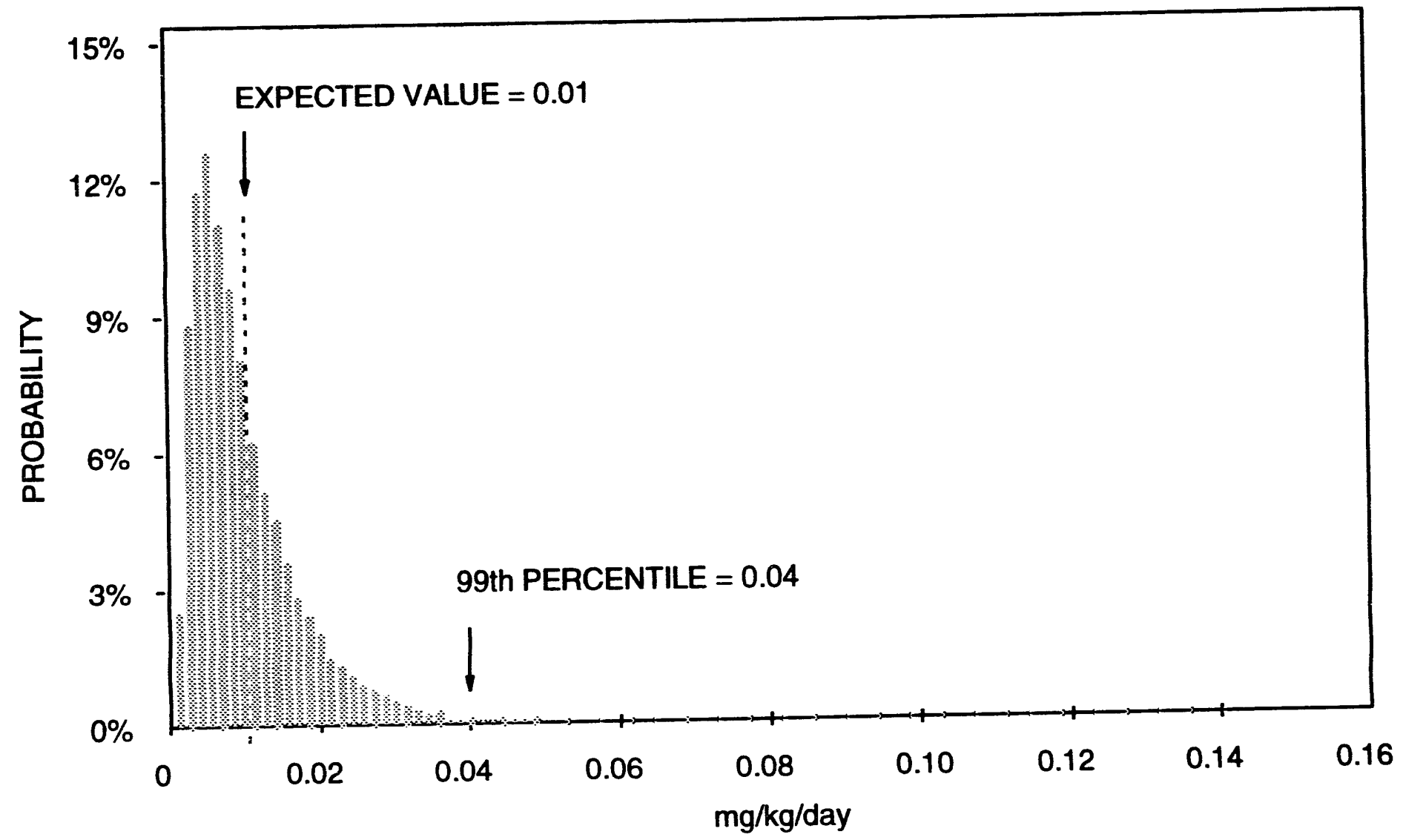

NOTE: AVERAGE POTENTIAL EXPOSURE IS $0.01 \mathrm{mg}$ COBALT/kg BODY WEIGHTIDAY. EXPOSURES FOR CHILDREN HAVE BEEN MODELED BECAUSE THEIR INTAKEKKg BODY WEIGHT IS GREATEST AND NO SENSTTIVE POPULATION HAS BEEN IDENTIFIED.

FIGURE 4.12

DISTRIBUTION OF POTENTIAL COBALT EXPOSURES FOR CHILDREN AS A RESULT OF GROUNDWATER INGESTION

GUNNISON, COLORADO, SITE 


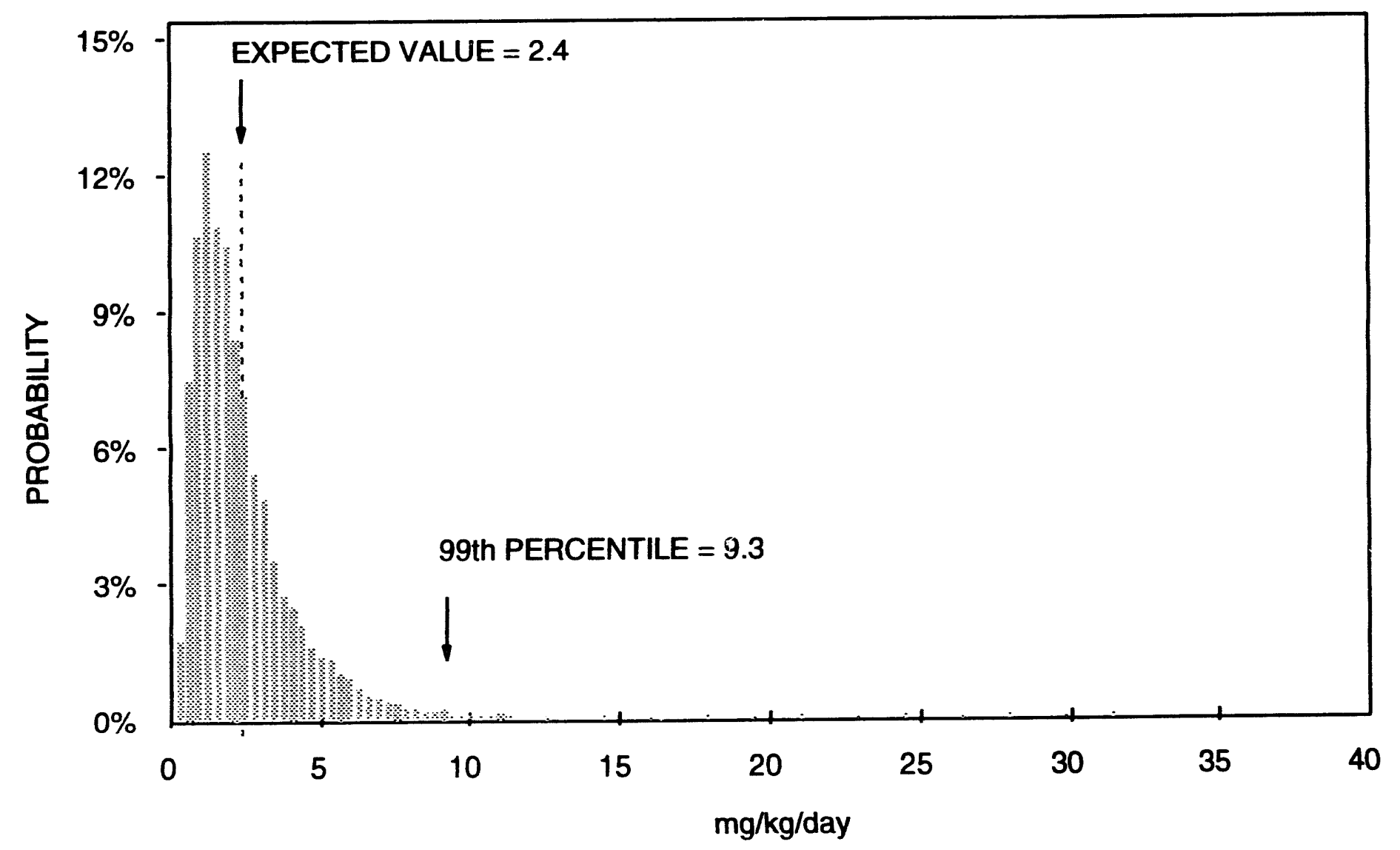

NOTE: AVERAGE POTENTIAL EXPOSURE IS $2.4 \mathrm{mg}$ IRON/kg BODY WEIGHTIDAY. EXPOSURES FOR CHILDREN HAVE BEEN MODELED BECAUSE THEIR INTAKERkg BODY WEIGHT IS GREATEST AND NO SENSITIVE POPULATION HAS BEEN IDENTIFIED.

FIGURE 4.13

DISTRIBUTION OF POTENTIAL IRON EXPOSURES FOR CHILDREN

AS A RESULT OF GROUNDWATER INGESTION

GUNNISON, COLORADO, SITE 


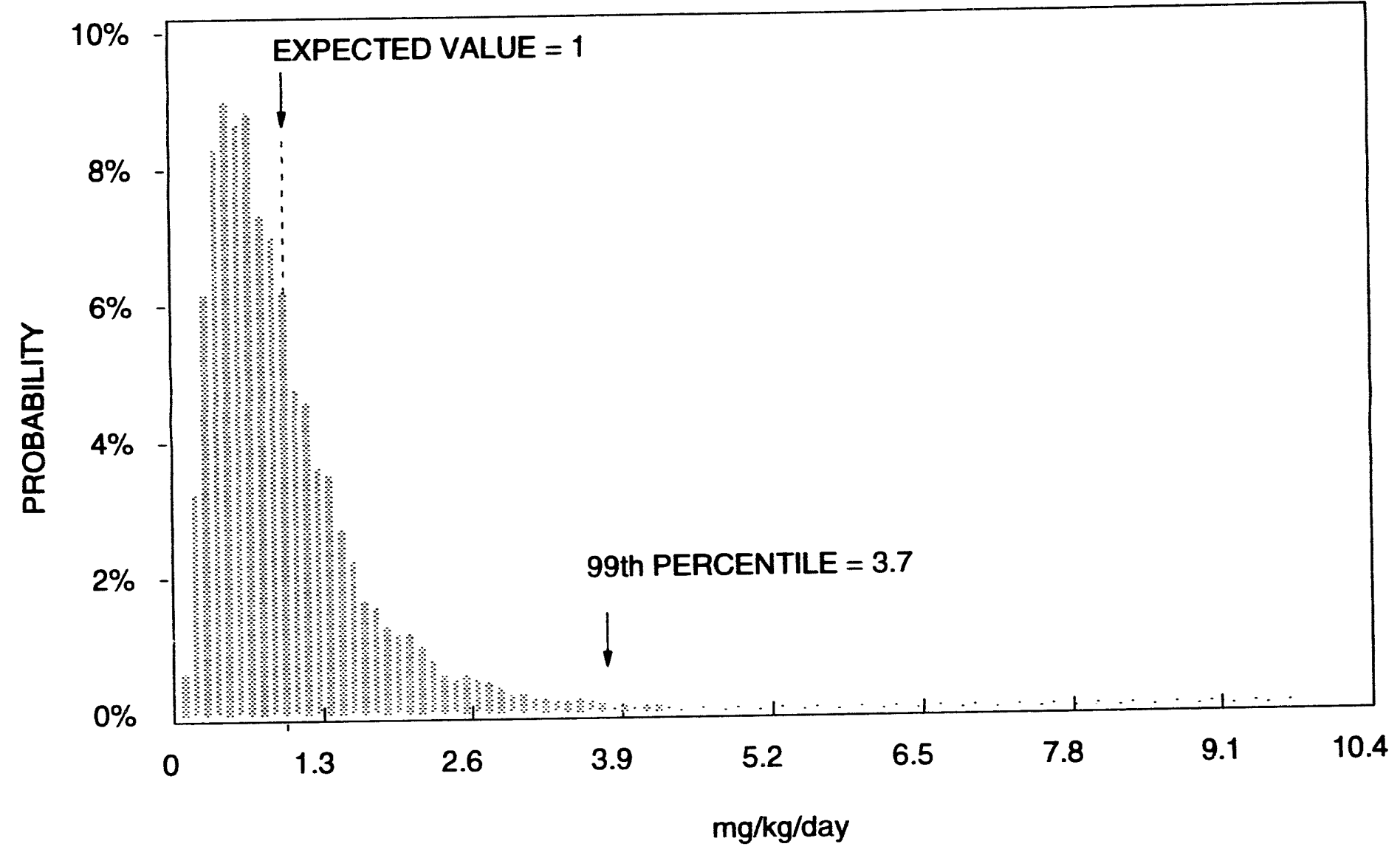

NOTE: AVERAGE POTENTIAL EXPOSURE IS $1 \mathrm{mg}$ MANGANESENKg BODY WEIGHT/DAY. EXPOSURES FOR CHILDREN HAVE BEEN MODELED BECAUSE THEIR INTAKERK BODY WEIGHT IS GREATEST AND NO SENSITIVE POPULATION HAS BEEN IDENTIFIED.

FIGURE 4.14

DISTRIBUTION OF POTENTIAL MANGANESE EXPOSURES FOR CHILDREN AS A RESULT OF GROUNDWATER INGESTION

GUNNISON, COLORADO, SITE 


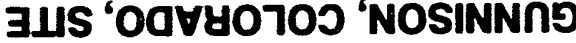

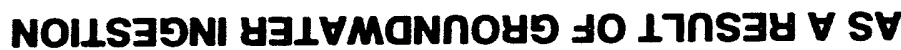

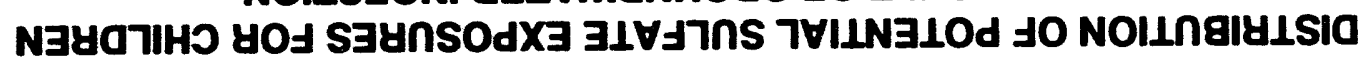

SL"b 3 \&nOId

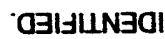

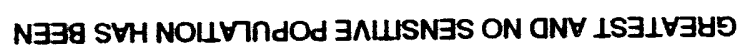

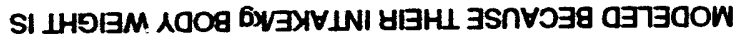

N五日 ヨА

6yت1

кер/6у /6u

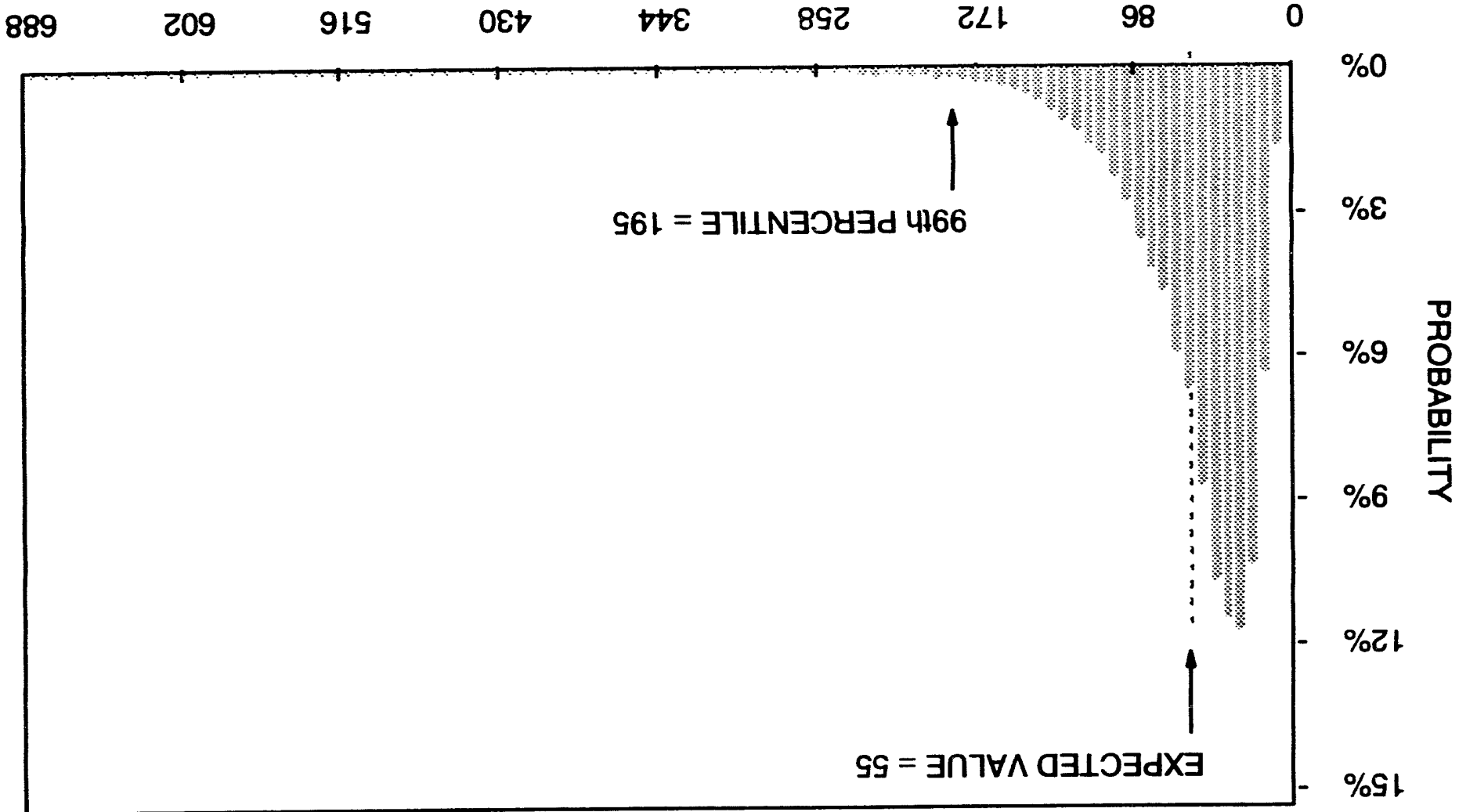




\subsection{EXPOSURE ASSESSMENT UNCERTAINTIES}

A number of potential sources of error may arise in all phases of the exposure assessment, including the following more significant sources of uncertainty:

- Uncertainties resulting from the lack of thorough environmental sampling data (groundwater, surface water, sediment, and biota), which could lead to an underestimate or overestimate in the exposure analysis.

- Uncertainties arising from the assumption that the groundwater contaminant source term at the site has reached a steady state and that contaminant concentrations at the exposure point will remain constant for chronic periods of exposure (generally greater than 7 years). Because the source of contamination at Gunnison is being removed, the assumption of a constant source will probably lead to an overestimation of risk.

- Uncertainties associated with the model used to estimate uptake of contaminants into plants for the irrigated garden produce pathway. Site-specific plant uptake factors could vary substantially from the default literature estimates. As with environmental sampling, the net effect on risk estimates of this uncertainty cannot be predicted.

- Uncertainties with bioconcentration factors (BCF) and meat transfer coefficients for the milk and meat ingestion pathways. Site-specific BCFs and transfer coefficients could vary substantially from the default literature values.

- Uncertainties associated with the relationship of an applied dose (used in this assessment) and absorbed dose or effective toxic dose.

- Uncertainties associated with differing sensitivities of subpopulations, such as individuals with chronic illnesses, that could alter predicted responses to contaminants.

Despite these uncertainties, the use of probability distributions that incorporate all definable sources of variability should provide a representative picture of the potential range of exposures. 


\subsection{TOXICITY ASSESSMENT}

Several contaminants that have the potential for causing adverse human health effects have been detected in groundwater at the site. This section summarizes the toxicological effects of the chemical contaminants and carcinogenic potentials of the radionuclides.

\subsection{CONTAMINANT TOXICITY SUMMARIES}

The following summaries address the basic toxicokinetics and toxicity of the six noncarcinogenic contaminants of concern at Gunnison based on the preliminary screening discussed previously. These are cadmium, cobalt, iron, manganese, sulfate, and uranium. Wherever possible, data from human studies are reported. Only in cases where human data are unavailable are animal studies reported. Although these contaminants have a wide range of toxic effects depending on the exposure levels, the following discussions focus most heavily on toxic effects observed in the exposure range most relevant to contamination at Gunnison.

\subsubsection{Cadmium}

\section{Absorption}

In humans, approximately 5 percent of ingested cadmium in water is absorbed, but this figure can increase substantially following exposure to other metals (such as calcium or iron) or with increased protein intake (Friberg et al., 1986). The amount of cadmium absorbed from food sources is about half the amount absorbed from water. Absorption is also substantially increased in individuals with low iron stores (Flanagan et al., 1978). Once absorbed, cadmium is bound to protein, primarily metallothionein. The ability of many metals to increase the concentration of metallothionein is likely the basis for interactions in absorption, tissue concentrations, and toxicity of combined exposures to metals.

\section{Tissue accumulation and clearance}

Humans with low-level exposure to cadmium show approximately 50 percent of the body burden in the kidneys, 15 percent in the liver, and 20 percent in muscle (Kjellström, 1979). The kidney concentration will increase with continued exposure only to about age 50, but the concentration in muscle will increase throughout life. In cases of high exposure resulting in kidney damage, kidney concentrations can be quite low, with liver concentrations up to 100 times higher than normal. Only 0.01 to 0.02 percent of the total body burden of cadmium is excreted daily, resulting in continuously increasing body burdens with continuous exposure. The biological half-time of cadmium, or the time necessary to eliminate 50 percent of the cadmium in the body at a given time, is 10 to 30 years in humans (Nordberg et al., 1985b). 


\section{Environmental sources of cadmium}

Normal cadmium content of food and water in nonpolluted areas results in 0.01 to $0.06 \mathrm{mg} /$ day intake of cadmium $[0.0001$ to 0.0009 milligrams per kilogram per day $(\mathrm{mg} / \mathrm{kg} /$ day $)$ ]. Cadmium occurs naturally with zinc and lead; it is therefore often present as an impurity in products using these metals, such as solders and galvanized metals. These sources lead to contact with water supplies in water heaters and coolers, some pipes, and taps.

\section{Toxicity f cadmium}

Acute exposure to high concentrations of cadmium (15 mg/L in water) results in acute gastrointestinal effects, including abdominal cramps, diarrhea, and vomiting $(0.07 \mathrm{mg} / \mathrm{kg}$ ). These gastrointestinal effects have not been reported in any chronic environmental exposure.

The primary toxic effect of long-term exposure to cadmium is disturbance of reabsorption in the proximal tubules of the kidney. This effect is first observed by an increase of low molecular-weight proteins in the urine. This initial effect is observed following a daily intake of $0.0075 \mathrm{mg} / \mathrm{kg} /$ day. Progressive disruption of kidney function will lead to an increase in amino acids, glucose, phosphate, and protein in urine. Long-term exposures can also disturb calcium metabolism, leading to osteoporosis and osteomalacia. A combination of these two effects is referred to as Itai-itai disease and was seen in epidemic proportions in a cadmiumcontaminated region in Japan in the 1950s (Friberg et al., 1986). These health effects are summarized in Figure 5.1 as a function of dose.

\subsubsection{Cobalt}

\section{Absorption}

Gastrointestinal absorption of soluble cobalt compounds can be estimated to be about 25 percent with wide individual variation; the gastrointestinal absorption in different individuals is reported to vary from 5 to 45 percent (Friberg et al., 1986).

Cobalt is an integral component of vitamin $B_{12}$. The total vitamin $B_{12}$ content of the body in a normal (i.e., nondeficient) human being is about 5 milligrams (mg), which is equivalent to about $0.2 \mathrm{mg}$ of cobalt (Friberg et al., 1986).

\section{Tissue accumulation and clearance}

In human beings exposed to cobalt, liver exhibits the highest concentration, followed by the kidneys. Excretion takes place mainly via the urinary tract. It appears that, independent of exposure route (inhalation, injection, or ingestion), 


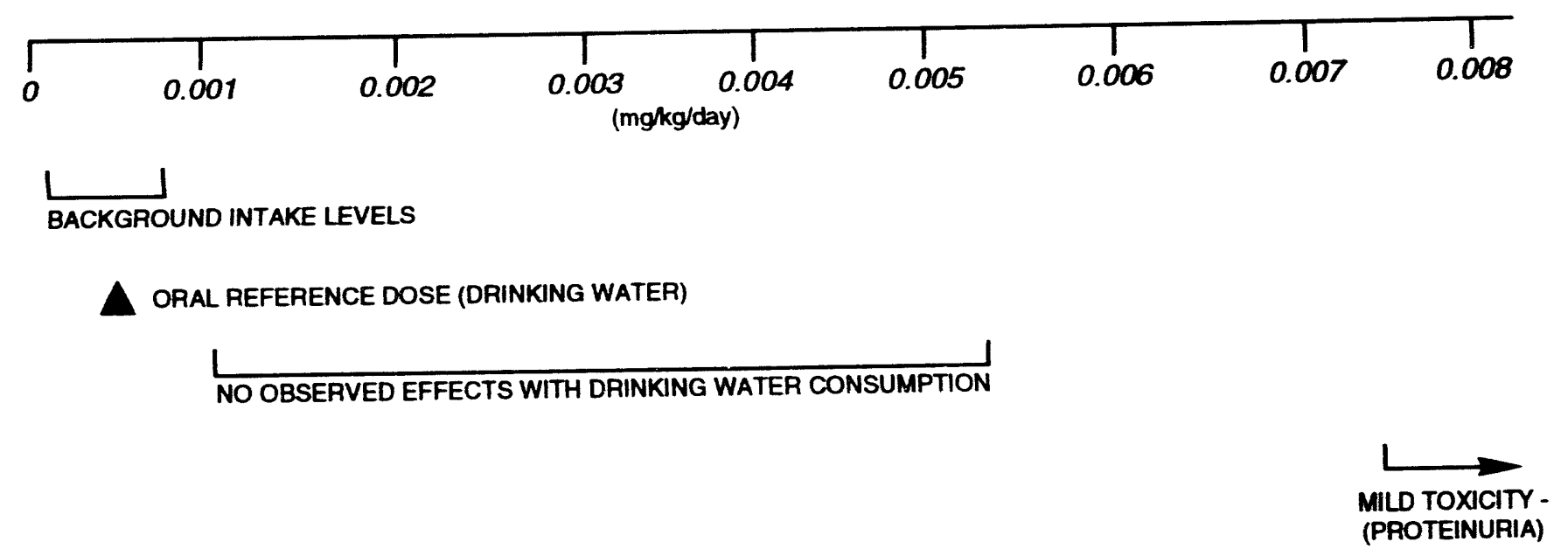

FGURE 5.1

CADMIUM TOXICTYY RANGES 
most cobalt will be eliminated rapidly (within days). A small proportion is, however, eliminated slowly, having a biological half-time on the order of years (Friberg et al., 1986).

Data are lacking on the levels of cobalt in tissues and fluids of normal populations (persons not occupationally exposed; i.e., background populatic . . ed States (ATSDR, 1991).

\section{Environmental sources of cobalt}

Compounds of cobalt occur naturally in seawater and in some surface, spring, and groundwaters. Cobalt is also released into water from industrial and commercial sources. Cobalt is a byproduct or coproduct of the refining of other mined metals such as copper and nickel (ATSDR, 1991).

Cobalt occurs naturally in the earth's crust and, as a result, in soil. Elevated levels of cobalt in soil can be caused by industrial activities such as mining and processing of cobalt-bearing ores and the disposal of wastes that contain cobalt (ATSDR, 19911 .

Few data are available on the levels of cobalt in U.S. foods. The average daily intake of cobalt from food is 5 to 45 micrograms $(\mu \mathrm{g})$ [approximately 0.00007 to 0.0006 milligrams per kilogram per day $(\mathrm{mg} / \mathrm{kg} /$ day)l. The recommended daily intake of $B_{12}$ for an adult is $3 \mu \mathrm{a}$ responding to $0.012 \mu \mathrm{g}$ of cobalt (Friberg et al., 1986).

\section{Toxicity of cobalt}

Cobalt is essential as an integral component of vitamin $B_{12}$. No function for cobalt in human nutrition other than as an integral part of the vitamin $B_{12}$ molecule has been established. Addition of cobalt to beer has caused endemic outbreaks of cardiomyopathy (damage to the heart muscle) among heavy beer drinkers, resulting in mortality rates of up to 50 percent. Similar effects on the heart, including myocardial degeneration and electrocardiographic changes, have also been seen in laboratory animals after repeated parenteral or peroral exposure to cobalt (Friberg et al., 1986).

Cobalt is used in the medical treatment of anemias and has an erythropoietic effect (i.e., it stimulates the production of red blood cells). Duckham and Lee (1976) gave 12 anemic patients daily doses of cobalt chloride orally in amounts corresponding to 6.2 and $12.4 \mathrm{mg}$ cobalt per day (approximately 0.09 to $0.18 \mathrm{mg} / \mathrm{kg} /$ day) for a period of 12 to 30 weeks. This treatment gave rise to an average increase in the hemoglobin concentration of 46 percent. After cobalt treatment ceased, the hemoglobin levels decreased. In adcition to cardiomyopathy, polycythemia (increased numbers of red blood cells) has also been reported in heavy drinkers of cobalt-contaminated beer. It may be assumed that a very heavy beer drinker 
consuming up to 10 liters (L) of beer a day acquires an additional $10 \mathrm{mg} / \mathrm{day}$ (approximately $0.14 \mathrm{mg} / \mathrm{kg} / \mathrm{day}$ ) of cobalt. Although this figure is excessively high compared with nutritional standards, it is not as large as doses given in the treatment of anemias (Friberg et al., 1986).

High levels of chronic oral administration may lead to goiter. Epidemiologic studies suggest that the incidence of goiter is higher in regions containing increased levels of cobalt in the water and soil. The goitrogenic effect has been elicited by the oral administration of 3 to $4 \mathrm{mg} / \mathrm{kg}(0.12$ to $0.16 \mathrm{mg} / \mathrm{kg} / \mathrm{day}$ for a $25-\mathrm{kg}$ child $)$ to children in the course of sickle cell anemia therapy (Casarett and Doull, 1991). The toxicity of cobalt is summarized in Figure 5.2.

\subsubsection{Iron}

\section{Absorption}

The percentage of dietary iron that is absorbed ranges from 2 percent in individuals with diseases of the gastrointestinal tract to 35 percent in rapidly growing, healthy children (Goyer, 1991; Whitney et al., 1990). Normally, 10 to 15 percent of dietary iron is absorbed, but this percentage varies to compensate for the level of iron in the body (Elinder, 1986). For example, patients with iron-deficiency anemia can absorb as high as 60 percent of an oral dose of iron (Josephs, 1958).

Apart from iron status, iron absorption is also influenced by factors such as condition of the gastrointestinal tract, source and chemical form of the ingested iron, and other substances in the diet (Elinder, 1986). Iron from animal sources is absorbed by humans more effectively than iron from vegetables and grains. Soluble forms of iron such as iron sulfate are taken up more readily than insoluble forms such as iron oxide. The presence of other metals also affects iron absorption. Absorption is decreased in the presence of high levels of phosphate, cobalt, copper, and zinc (Elinder, 1986), and excess manganese can significantly decrease absorption of iron by impairing hemoglobin regeneration in the blood (National Research Council, 1980l.

\section{Tissue accumulation and clearance}

Normally, the adult human body contains about 3 to 5 grams of iron. Two-thirds of this amount is found in the blood bound to hemoglobin. Less than 10 percent of the body iron is found in myoglobin and iron-requiring enzymes. Of the remaining amounts of iron, about 20 to 30 percent of the body pool is bound to iron-storage proteins in liver, bone marrow, and spleen (Elinder, 1986).

Under normal conditions, the total elimination of iron from the body is limited to 0.6 to $1.0 \mathrm{mg} / \mathrm{day}$, or roughly 0.01 percent of the body stores. Not counting iron not absorbed from the gut, about 0.2 to $0.5 \mathrm{mg}$ elemental iron/day is eliminated via feces, about 0.1 to $0.3 \mathrm{mg} / \mathrm{day}$ is eliminated in urine, and the remainder is lost via 


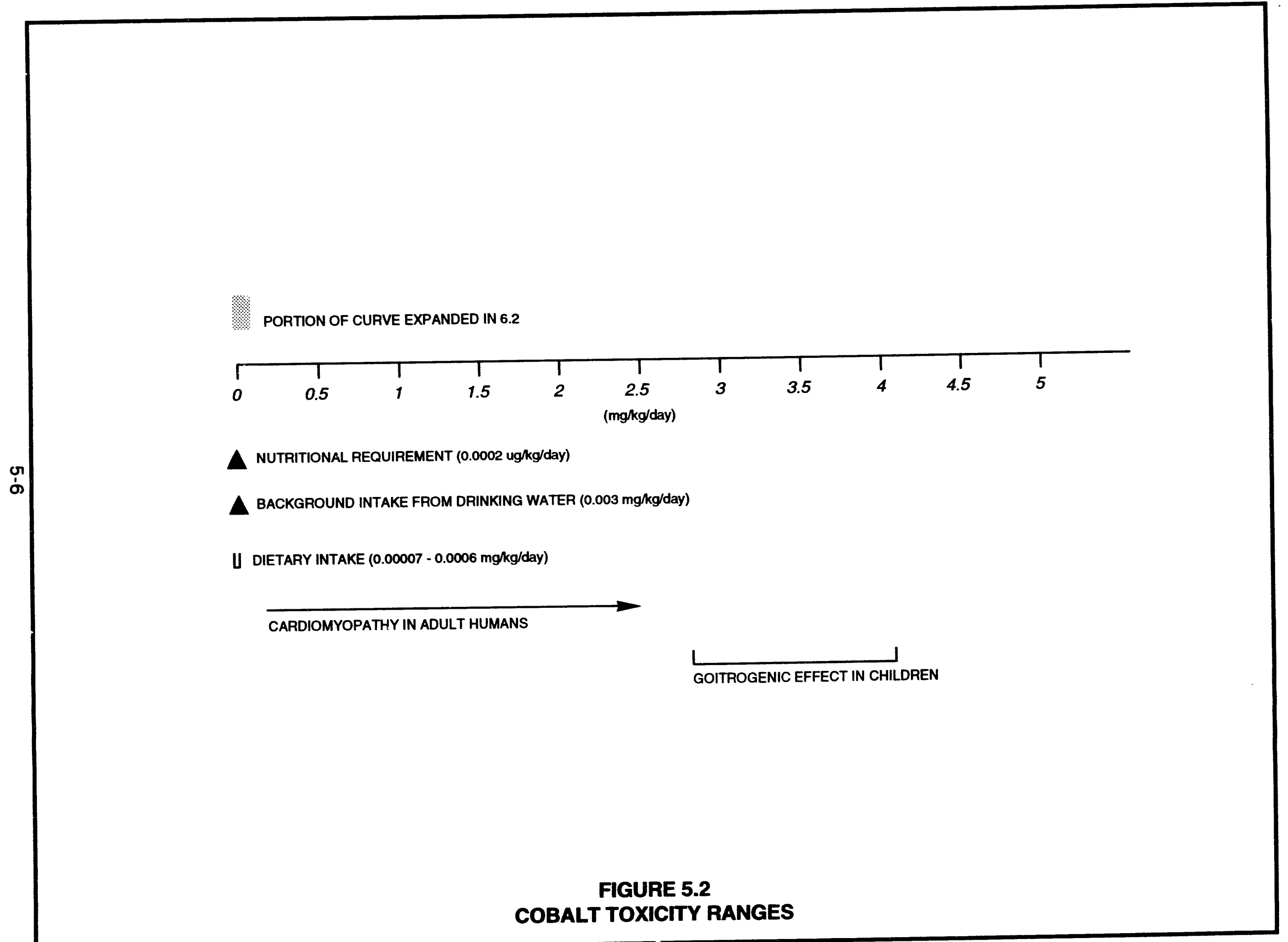


normal dermal losses in sweat, hair, and nails. Based on these rates of elimination, the biological half-time of iron in the body is 10 to 20 years (Elinder, 1986).

\section{Environmental sources of iron}

In general, liver, kidney, beef, ham, egg yolk, and soybeans have iron concentrations in the order of 30 to $150 \mathrm{mg} / \mathrm{kg}$ fresh weight. Grains and fruits are low in iron, usually ranging from 1 to $20 \mathrm{mg} / \mathrm{kg}$. In both human and cow's milk, iron concentration is about $0.5 \mathrm{mg} / \mathrm{L}$ (Elinder, 1986).

The daily intake of iron varies greatly with the total amount of food consumed and the proportions of iron-rich and iron-poor food in the diet. In general, reported daily intakes have ranged from 9 to $35 \mathrm{mg} /$ day $(0.1$ to $0.5 \mathrm{mg} / \mathrm{kg} /$ day) (Elinder, 1986). Approximately 35 percent of the dietary iron comes from meat, fish, and eggs, while 50 percent is supplied by cereals, root vegetables, and other foods of plant origin (National Research Council, 1980).

Iron concentrations in water vary greatly. In the United States, freshwater and public water supplies, in general, have iron concentrations ranging from 0.01 to $1.0 \mathrm{mg} / \mathrm{L}$ (Elinder, 1986). Assuming water consumption of $2 \mathrm{~L} / \mathrm{day}$, this range would result in an intake range of 0.02 to $2 \mathrm{mg} /$ day of iron from drinking water.

The recommended daily allowance (RDA) for iron is $10 \mathrm{mg}$ (approximately 0.14 $\mathrm{mg} / \mathrm{kg} /$ day) for adult males and $18 \mathrm{mg}$ (approximately $0.25 \mathrm{mg} / \mathrm{kg} / \mathrm{day}$ ) for females of reproductive age (National Research Council, 1980).

\section{Toxicity of iron}

Iron intoxication is most frequently observed in children 1 to 5 years old, caused by consuming iron supplements formulated for adults in the form of ferrous sulfate tablets with candy-like coatings. Severe poisoning in children may occur following ingestion of more than 0.5 grams (approximately $22 \mathrm{mg} / \mathrm{kg}$ ) of iron, about $2.5 \mathrm{~g}$ $(110 \mathrm{mg} / \mathrm{kg})$ as ferrous sulfate. This acute iron poisoning has occurred in children with ingestion of as few as 6 iron tablets (Whitney et al., 1990). The iron damages the lining of the gastrointestinal tract, producing vomiting as the first symptom. Bleeding of the damaged gastrointestinal tissue frequently results in blood in the vomit and black stools (Goyer, 1991). Shock and metabolic acidosis can develop. If the patient survives the initial crisis, liver damage with hepatitis and coagulation defects often occur within a couple of days. Renal failure and cirrhosis of the liver may occur as delayed effects (Elinder, 1986).

Long-term intake of iron in a form that is readily absorbed and in doses exceeding 50 to $100 \mathrm{mg}$ of iron per day $(0.7$ to $1.4 \mathrm{mg} / \mathrm{kg} / \mathrm{day}$ ) (Elinder, 1986) results in an increased body burden of iron, because iron is removed from the body at a much slower rate than it is absorbed. As the body burden of iron increases to between 20 and $\mathbf{4 0}$ grams (roughly 10 times the normal level), production of the iron-binding 
protein hemosiderin increases and results in a condition known as hemochromatosis. This condition starts with increased pigmentation of the skin and higher concentrations of iron in the liver, pancreas, endocrine organs, and heart. This increased tissue iron can produce cirrhosis in the liver, disturbances in endocrine and cardiac function, and diabetes mellitus (Goyer, 1991).

Chronic iron toxicity in adults can occur from genetic factors, excess dietary iron, excessive ingestion of iron-containing tonics or medicines, or a therapeutic program of multiple blood transfusions. The pathologic consequences of iron overload are similar, regardless of basic cause (Goyer, 1991).

The toxic effects and doses for iron are summarized in Figure 5.3.

\subsubsection{Manganese}

\section{Absorption}

Following ingestion, manganese absorption is homeostatically controlled: the rate of absorption depends on both the amount ingested and tissue levels of manganese. For adult humans, approximately 3 to 4 percent of dietary manganese is absorbed (Saric, 1986). Manganese can be absorbed following exposure by inhalation, ingestion, and dermal contact. In humans, available data on absorption indicate that only 3 percent of an ingested dose of manganese chloride is absorbed (Mena et al., 1969). The rate of absorption is influenced by iron and other metals. In states of iron deficiency, manganese is actively absorbed from the intestine. Individuals with anemia can absorb more than twice the percentage of an ingested dose. However, in states of excess iron, absorption of manganese is by diffusion only (Saric, 1986). High levels of dietary calcium and phosphorus have been shown to increase the requirements for manganese in several species (Lönnerdal et al., 1987).

\section{Tissue accumulation and clearance}

Manganese is widely distributed throughout the body. Highest concentrations are found in the liver, kidney, and, to a lesser extent, the hair. Biological half-life in humans is 2 to 5 weeks, depending on body stores. Manganese readily crosses the blood-brain barrier and is more slowly cleared from brain tissues than from other tissues (Goyer, 1991). Normal concentrations in brain tissues are low, but the half-life in the brain is longer and the metal may accumulate in the brain with excessive absorption (National Research Council, 1980).

Absorbed manganese is rapidly eliminated from the blood and concentrates in mitochondria. Initial concentrations are greatest in the liver. Manganes jenetrates the placental barrier in all species and is more uniformly distributed throlynout the fetus than in adult tissues. It is secreted into milk. 


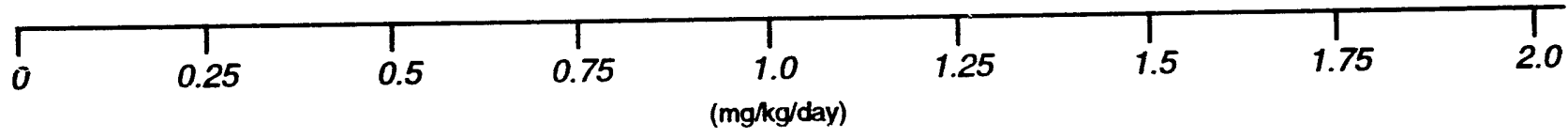

$\triangle$ RDA FOR ADULT MEN $(0.14 \mathrm{mg} / \mathrm{kg} /$ day $)$

$\triangle$ RDA FOR ADULT WOMEN $(0.25 \mathrm{mg} / \mathrm{kg} / \mathrm{day})$

DIETARY INTAKE RANGE

INCREASED IRON IN ORGANS, SKIN PIGMENTATION

CIRRHOSIS WITH INCREASED DOSES

ACUTE SEVERE POISONING IN CHILDREN (22 mg/kg)

FIGURE 5.3

IRON TOXICITY RANGES 
Absorbed manganese is almost totally secreted in bile and reabsorbed from the intestine as necessary to maintain body levels. At excessive exposure levels, other gastrointestinal routes may participate. Excess manganese is eliminated in the feces; urinary excretion is negligible (Goyer, 1991; Saric, 1986).

\section{Environmental sources of manganese}

On the whole, food constitutes the major source of manganese intake for humans. The highest manganese concentrations are found in plants, especially wheat and rice. Drinking water generally contains less than $100 \mu \mathrm{g} / \mathrm{L}$. Manganese levels in soil range from 1 to $7000 \mathrm{mg} / \mathrm{kg}$, with an average of 600 to $900 \mathrm{mg} / \mathrm{kg}$. Mining and natural geological background variation can contribute to this variability. Manganese bioaccumulates in marine mollusks up to 12,000 -fold, and there is evidence for toxic effects in plants (phytotoxicity) and plant bioaccumulation.

Variations in manganese intake can to a large extent be explained by differences in nutritional habits. In populations with cereals and rice as main food sources, the intake will be higher compared to areas where meat and dairy products make up a larger part of the diet. The average daily intake has been estimated to be between 2.0 to $8.8 \mathrm{mg} /$ day $(0.03$ to $0.13 \mathrm{mg} / \mathrm{kg} / \mathrm{day}$ ) (EPA, 1993), but intakes as high as $12.4 \mathrm{mg}$ (approximately $0.2 \mathrm{mg} / \mathrm{kg} /$ day) have been reported in countries with high cereal intake (Saric, 1986).

Drinking water generally results in an intake of less than $200 \mu \mathrm{g}(0.003 \mathrm{mg} / \mathrm{kg} / \mathrm{day})$, although some mineral waters can increase this amount by more than threefold (Saric, 1986). One study from Greece reported drinking water concentrations of manganese in excess of $2 \mathrm{mg} / \mathrm{L}$, which would result in daily intakes in the range of 0.06 to $0.07 \mathrm{mg} / \mathrm{kg} /$ day (EPA, 1993).

\section{Toxicity of manganese}

Manganese is an essential nutrient. Estimated safe and adequate daily dietary intakes for adults range from 0.03 to $0.07 \mathrm{mg} / \mathrm{kg} /$ day (Saric, 1986). The EPA noobserved-adverse-effect level (NOAEL) for drinking water is set at 0.005 $\mathrm{mg} / \mathrm{kg} /$ day, while the lowest-observed-adverse-effect level (LOAEL) for drinking water sources is $0.06 \mathrm{mg} / \mathrm{kg} /$ day. The EPA RfD for drinking water is 0.005 $\mathrm{mg} / \mathrm{kg} /$ day. The reference dose for food ingestion is $0.14 \mathrm{mg} / \mathrm{kg} / \mathrm{day}$. There is some indication that manganese in drinking water is potentially more bioavailable (i.e., more readily absorbed) than is manganese in dietary food sources. This would result in tcxic effects with lower ingested doses of manganese in drinking water than in food (EPA, 1993).

Inhalation of manganese in industrial settings has provided the largest source of data on chronic manganese toxicity. These data indicate that excess manganese can result in a central nervous system disorder consisting of irritabilit, difficulty in walking, speech disturbances, and compulsive behavior that may include running, 
fighting, and singing. With continued exposure, this condition can progress to a mask-like face, retropulsion or propulsion, and a Parkinson's-like syndrome. The condition reverses slowly with removal of manganese exposure. Metal chelating agents are ineffective in treatment, but L-dopa has been effective in treatment (Goyer, 1991).

Limited information is available on the effects of manganese ingestion. Because effects from drinking water seem to differ from those from food sources, only studies on water consumption will be considered here. A Japanese study of 25 people drinking well water with manganese concentrations of $14 \mathrm{mg} / \mathrm{L} 10.4$ $\mathrm{mg} / \mathrm{kg} /$ day estimated intake) reported symptoms of intoxication, including a mask-like face, muscle rigidity and tremors, and mental disturbances. There were two cases ( 8 percent) of death among intoxicated people. A Greek study of over 4000 individuals drinking water with manganese concentrations varying from 81 to $2300 \mathrm{mg} / \mathrm{L}$ lestimated intake at $2 \mathrm{~L} /$ day for a $70-\mathrm{kg}$ individual ranges from 0.002 to $0.07 \mathrm{mg} / \mathrm{kg} / \mathrm{day}$ ) showed neurological effects in individuals drinking from 0.05 to $0.07 \mathrm{mg} / \mathrm{kg} / \mathrm{day}$, but no effects in individuals drinking less than $0.007 \mathrm{mg} / \mathrm{kg} / \mathrm{day}$ (Konrjakis et al., 1989).

The chemical form of manganese has complex effects on its toxicity. Although more soluble forms are more readily absorbed from the gastrointestinal tract, they also appear to be more rapidly cleared. Exposure to insoluble forms results in lower manganese absorption but higher chronic tissue levels, and therefore greater toxicity (EPA, 1993). Only limited information is available on the effects of various forms of manganese.

Few data are available on manganese toxicity in infants, but it is likely that infants will be more susceptible to toxicity due to greater absorption and greater penetration into the central nervous system (EPA, 1993; Saric, 1986).

The toxicity of manganese from drinking water exposure is summarized in Figure 5.4 .

\subsubsection{Sulfate}

\section{Absorption}

Sulfate absorption from the gastrointestinal tract is similar between humans and other animals. Generally, greater than 90 percent absorption has been reported for doses of sulfate below $150 \mathrm{mg} / \mathrm{kg}$, decreasing to 50 to 75 percent as the dose increases into the grams per kilogram range.

\section{Tissue accumulation and retention}

Ingestion of high levels of sulfate results in transient increases in both blood and urine concentrations. For sulfate doses of approximatel; $75 \mathrm{n}: \mathrm{g} / \mathrm{kg}$, approximately 


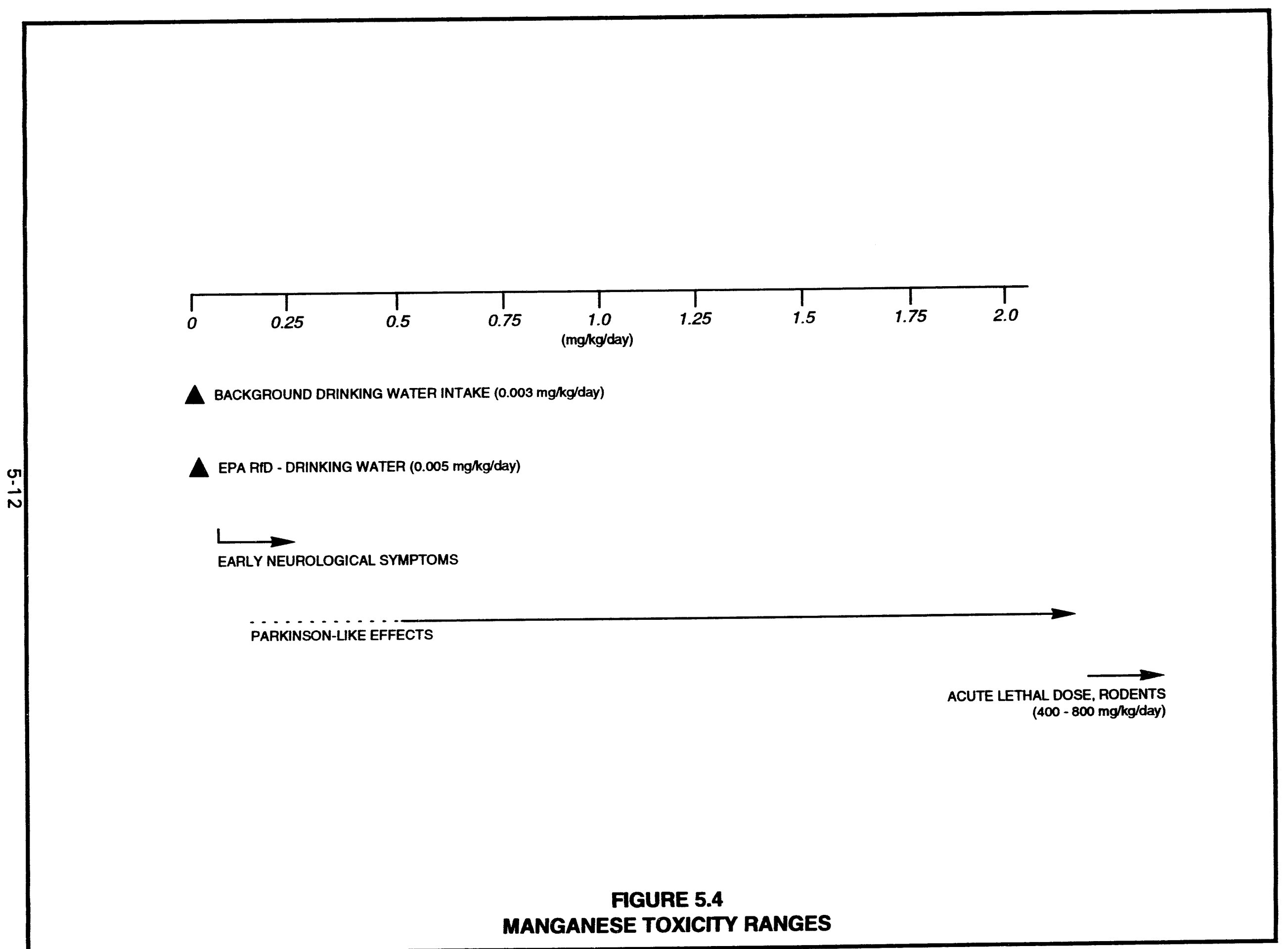


50 percent of the dose is excreted over 72 hours. The urinary excretion mechanism is transport-limited and can therefore become saturated at high doses of sulfate. Excess sulfate is also excreted in feces in its inorganic form. To date, no data are available that indicate sulfate is accumulated, even with chronic ingestion of above-normal levels. However, extremely high chronic doses do not appear to have been examined in humans.

Sulfate is used in the biosynthesis of collagen, cartilage, and dentin and in the formation of sulfate esters of both endogenous compounds (such as lipids and steroids) and exogenous compounds (such as phenols). Sulfation is important in detoxication pathways because it increases the solubility of these compounds, which enhances their excretion in the urine. Exposure to high concentrations of compounds that are conjugated with sulfate and excreted can produce a transient decrease in sulfate concentrations in plasma.

\section{Environmental sources of sulfate}

Drinking water in the western United States in 1978 showed a range of sulfate concentrations from 0 to $820 \mathrm{mg} / \mathrm{L}$, with a mean concentration of $99 \mathrm{mg} / \mathrm{L}$ of sulfates. The EPA estimates a normal sulfate intake range of 0.00023 to $0.0064 \mathrm{mg} / \mathrm{kg} / \mathrm{day}$ from air and up to $2.9 \mathrm{mg} / \mathrm{kg} / \mathrm{day}$ from drinking water in the concentration range found in western United States supplies. No estimates are available on intake of sulfates from food sources.

\section{Toxicity of sulfate}

The acute and chronic effects of sulfate toxicity differ more in severity than in symptoms or mechanisms. Therefore, this discussion will combine acute and chronic toxicity. As mentioned above, there are no data to indicate a bioaccumulation of sulfate with chronic exposure. Sulfate salts of magnesium and sodium are used medicinally as cathartics. The presence of high concentrations of unabsorbed sulfate salts in the gut can pull large amounts of water into the gut, greatly increasing the normal volume of feces. This is the basis of the toxic effects as well.

Toxicity in humans is primarily manifested in diarrhea; the severity of the diarrhea depends on the dose. Chronic ingestion of sulfate can result in persistent diarrhea, leading to ionic imbalances and dehydration similar to that seen with extremely high acute doses. In the case of drinking water contaminated with sulfate, the taste of the water may make it unpalatable and reduce consumption. This lower water intake could compound the dehydration effects of the diarrhea. Extreme dehydration can lead to death. Infants seem to be the most susceptible population for sulfate-induced diarrhea. These health effects are summarized in Figure 5.5 as a function of dose. 


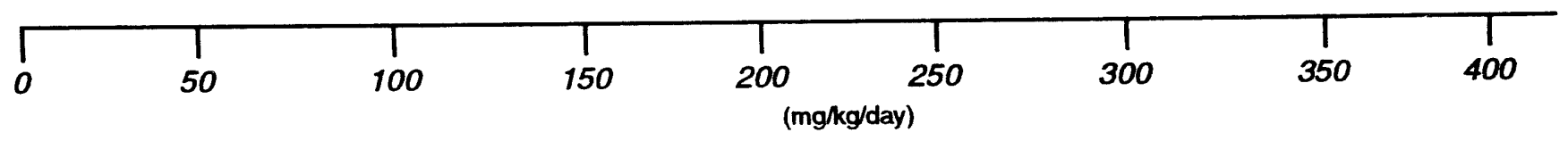

bACKGROUND INTAKE LEVELS

$\frac{\vec{D}}{\vec{D}}$

NO OBSERVED EFFECTS

MILD TOXICITY RANGING FROM LAXATIVE EFFECT (ADULTS) TO DIARRHEA IN INFANTS

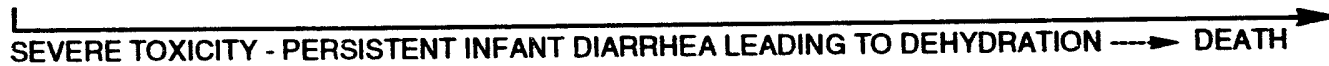

FIGURE 5.5

SULFATE TOXICITY RANGES FOR INFANTS

MAC: STTE/GUNBRASULFTOXRG 
In cattle, high sulfate intake has resulted in sulfhemoglobinemia, a condition similar to the methemoglobinemia induced by nitrate ingestion. No reports of sulfhemoglobinemia have been reported following ingestion of sulfate by humans, although the condition does occur in humans following inhalation of hydrogen sulfide.

Data on sulfate toxicity are based primarily on epidemiologic studies of human adults and infants who report to hospitals with symptoms of sulfate exposure. In most cases, exposure doses have been back-calculated from sampling their drinking water. Therefore, these data do not represent well-controlled studies where dosage ranges can be readily defined.

\subsubsection{Uranium}

Naturally occurring uranium, present at UMTRA Project sites, consists of three radioactive isotopes: uranium-234, uranium-235, and uranium-238. More than 99 percent of natural uranium occurs in the form of uranium-238 (Cothern and Lappenbusch, 1983). Uranium-238 undergoes radioactive decay by emitting alpha particles to form uranium-234, thorium-230, radium-226, radon-222, polonium-210, and other radioisotopes. The radioactive decay chain of uranium-238 and uranium-234 is summarized in Figure 5.6. As all uranium isotopes in nature are radioactive, the hazards of a high uranium intake are its chemical toxicity and potential radiological damage. This chapter focuses on the chemical toxicity of natural uranium. Carcinogenic potential associated with exposure to radioactive isotopes of natural uranium is discussed in Section 5.3.

\section{Absorption}

Absorption of uranium in the gastrointestinal tract depends on the solubility of the uranium compounds. The hexavalent uranium compounds, especially the uranyl salts, are water soluble, while tetravalent compounds generally are not (Weige!, 1983). Even with soluble compounds, only a small fraction is absorbed. Human gastrointestinal absorption rates of 0.76 to 7.8 percent have been determined (Wrenn et al., 1985).

\section{Tissue accumulation and clearance}

In humans exposed to background levels of uranium, the highest concentrations of uranium were found in the bone, muscle, lung, liver, and kidney (Fisenne et al., 1988). There are two components to the retention of uranium in the bone: a short retention half-time of 20 days followed by a long retention half-time of 5000 days (Tracy et al., 1992).

In body fluids, uranium tends to be converted into water-soluble hexavalent uranium (Berlin and Rudell, 1986). Approximately 60 percent of the uranium in plasma 

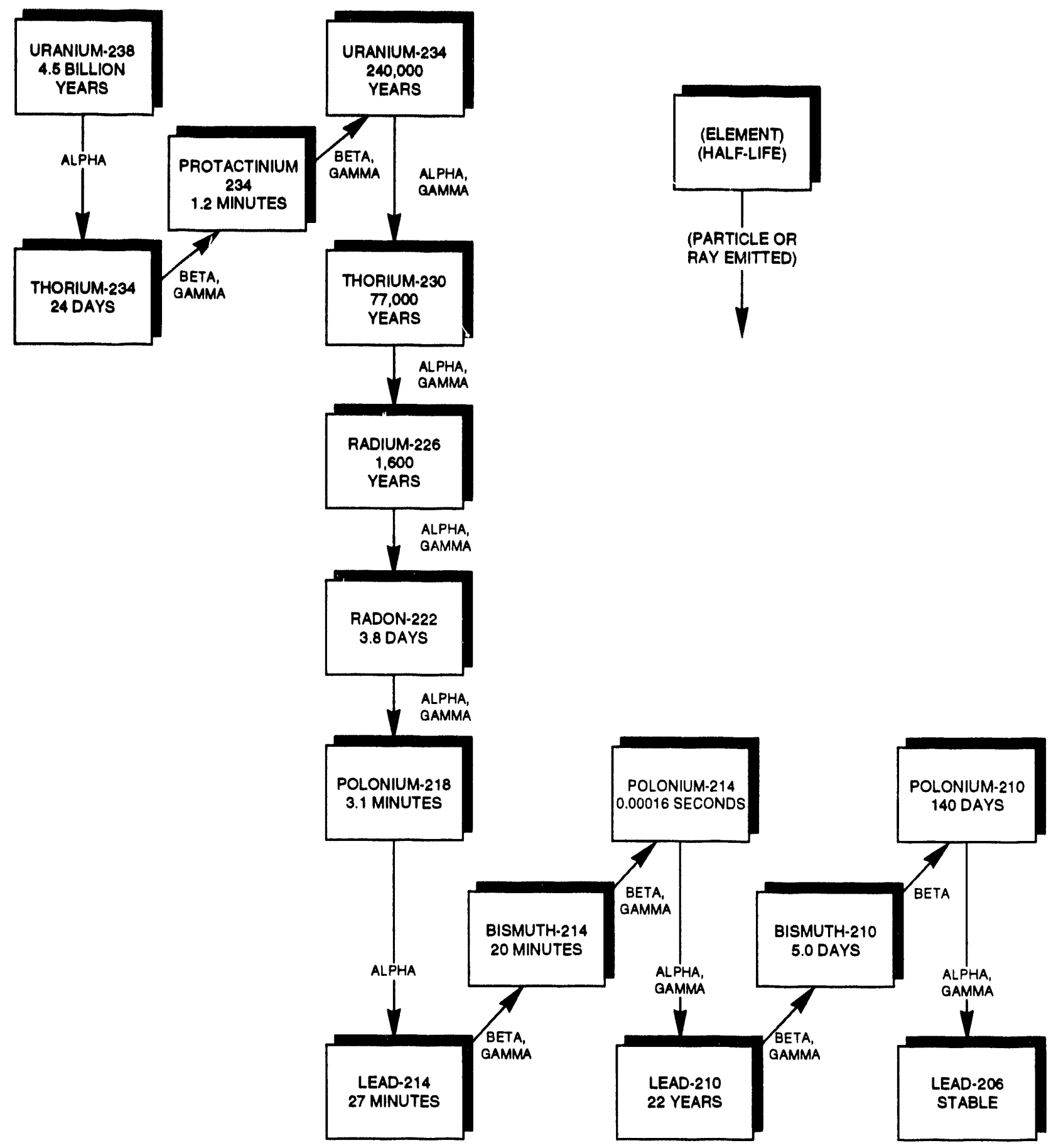

FIGURE 5.6

HALF-LIVES AND EMISSIONS FROM DECAY CHAIN OF URANIUM-238 GUNNISON, COLORADO, SITE 
complexes with low-molecular-weight anions (e.g., bicarbonates, citrates), while the remaining 40 percent binds to the plasma protein transferrin (Stevens et al., 1980). Following oral exposure in humans, more than 90 percent of uranium that has not been absorbed from the gastrointestinal tract is excreted in the feces. Of the small percent that is absorbed (typically less than 5 percent), approximately 60 percent is excreted in the urine within 24 hours and 98 percent is excreted within 7 days, based on animal studies (Ballou et al., 1986; Leach et al., 1984; Sullivan et al., 1986). A small portion of the absorbed uranium is retained for a longer period.

\section{Environmental sources of urunium}

Uranium is a ubiquitous element, present in the earth's crust at approximately 4 parts per million. Uranium concentrations in groundwater and surface water averaged 1 picocurie per liter $(\mathrm{pCi} / \mathrm{L})$ and $3 \mathrm{pCi} / \mathrm{L}$, respectively (NCHP, 1984). It is absorbed from the soil into plant tissues to an extent that depends on the plant species and the depth of its root system (Berlin and Rudell, 1986). Plant concentrations of uranium averaged 0.075 micrograms per kilogram $(\mu \mathrm{g} / \mathrm{kg})$ fresh plant material (Tracy et al., 1983).

The main source of uranium for the general population is food products such as potatoes, bakery products, meat, and fresh fisn, which may contain uranium concentrations between 10 and $100 \mu \mathrm{g} / \mathrm{kg}$ (Prister, 1969). The total dietary intake of uranium from the consumption of average foods is approximately $1 \mu \mathrm{g} / \mathrm{day}$. Cereals and vegetables, particularly root crops, are likely to contribute most to the daily intake of uranium (Berlin and Rudell, 1986).

\section{Toxicity of uranium}

Exposure of the general public to natural uranium is unlikely to pose an immediate lethal threat to humans. No human deaths have been reported that are definitely attributable to the uranium exposure. The lethal doses in animals range from 8 to $242 \mathrm{mg} / \mathrm{kg}$, depending on the solubility of the uranium compound tested (higher solubility compounds having greater toxicity) and animal species. High doses of uranium cause complete kianey and respiratory failure.

No chronic toxic effects have been reported in humans following oral exposure to uranium. Data available from populations occupationally exposed to high concentrations of uranium compounds through inhalation and information from studies in experimental animals indicate that the critical organ for chronic uranium toxicity is the proximal tubule of the kidney (Friberg et al., 1986). In humans, chemical injury reveals itself by increased catalase excretion in urine and proteinuria. Dose-response data for the toxic effect of uranium on the human kidney are limited. 


$$
\begin{aligned}
& \text { 震 }
\end{aligned}
$$

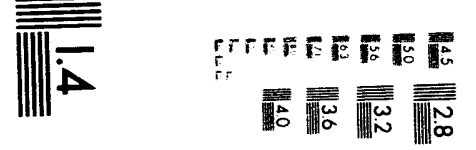

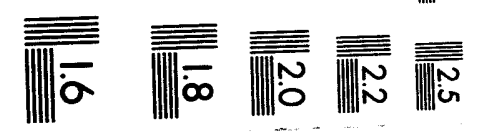



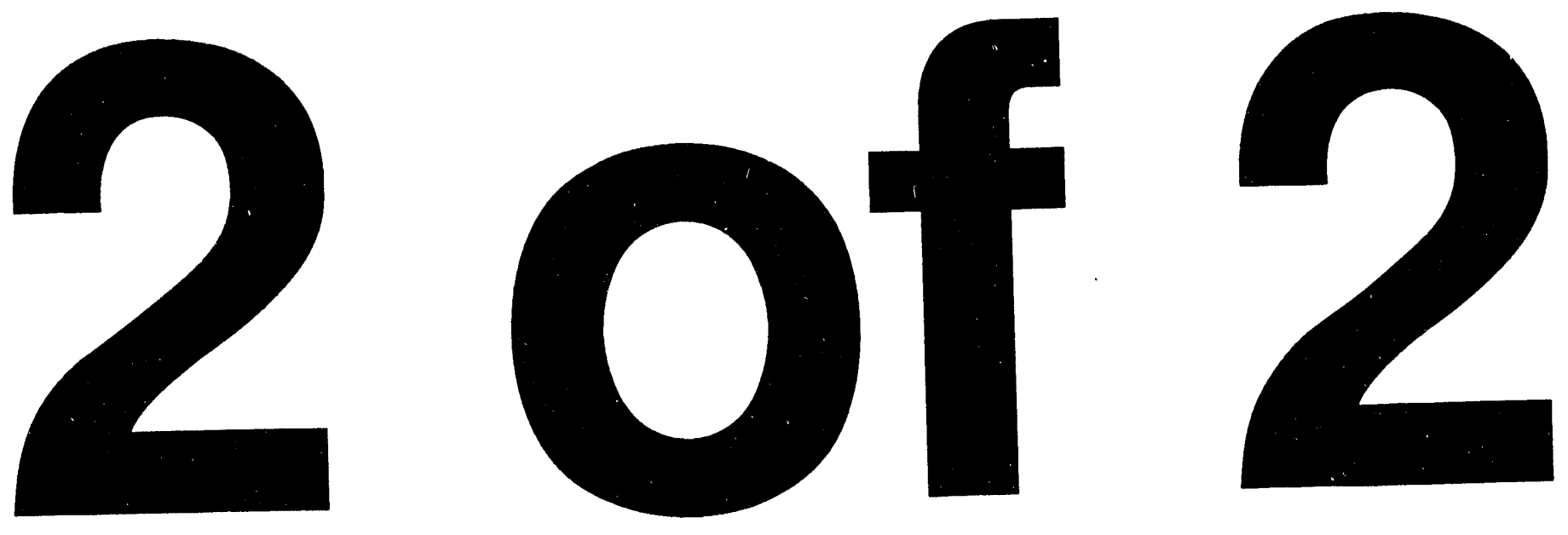
The lowest dose of uranyl nitrate that caused moderate renal damage was given to rabbits in diet at $2.8 \mathrm{mg} / \mathrm{kg} / \mathrm{day}$ (Maynard and Hodge, 1949). The health effects for uranium are summarized in Figure 5.7 as a function of dose.

\subsection{CONTAMINANT INTERACTIONS}

The primary concern for interaction between contaminants at Gunnison is between manganese and iron. Excess manganese impairs hemoglobin regeneration in the blood and thereby significantly decreases absorption of iron (National Research Council, 1980). However, excess iron inhibits the absorption of manganese (Saric, 1986). Even though an excess of either contaminant can inhibit the absorption of the other, it is not clear what the net result of a significant excess of the two in combination would be.

In addition to interactions between manganese and iron, interactions between several similar metals can alter the predicted absorption, distribution in the body, metabolism, toxicity, or clearance of a metal of interest. Cobalt can decrease iron absorption, and the absorption of cadmium can be considerably increased under conditions of low intake of calcium, iron, or protein (Nordberg et al., 1985). Low body iron stores, although unlikely in people drinking contaminated groundwater from the Gunnison site, can increase cadmium uptake fourfold (Flanagan et al., 1978). Because cadmium binds strongly to metallothionein and its toxicity depends on this binding, metals that increase metallothionein concentrations will increase cadmium binding and potentially its toxicity. Metallothioneins can be induced or increased by exposure to a wide range of other metals, including copper and zinc. However, in the continued presence of these other metals, there may be competition for metallothionein binding sites.

In animal studies, iron status affected the absorption of uranium (EPA, 1989a). The common target organ for uranium suggests interaction with cadmium in the production of kidney toxicity.

Sulfate, although not known to physiologically interact directly with any of the other contaminants, induces diarrhea, which can alter the elimination of other toxicants. This might be expected to be a significant factor in the elimination and reabsorption of manganese, which occurs almost solely in the intestine.

\subsection{CONTAMINANT RISK FACTORS}

The EPA Office of Research and Development has calculated acceptable intake values, or RfDs, for long-term (chronic) exposure to noncarcinogens. These values are estimates of route-specific exposure levels that would not be expected to cause adverse effects when exposure occurs for a significant portion of the lifetime. The RfDs include safety factors to account for uncertainties associated with limitations of the toxicological data base, including extrapolating animal studies to humans and accounting for variability in response from sensitive individuals. These values are 


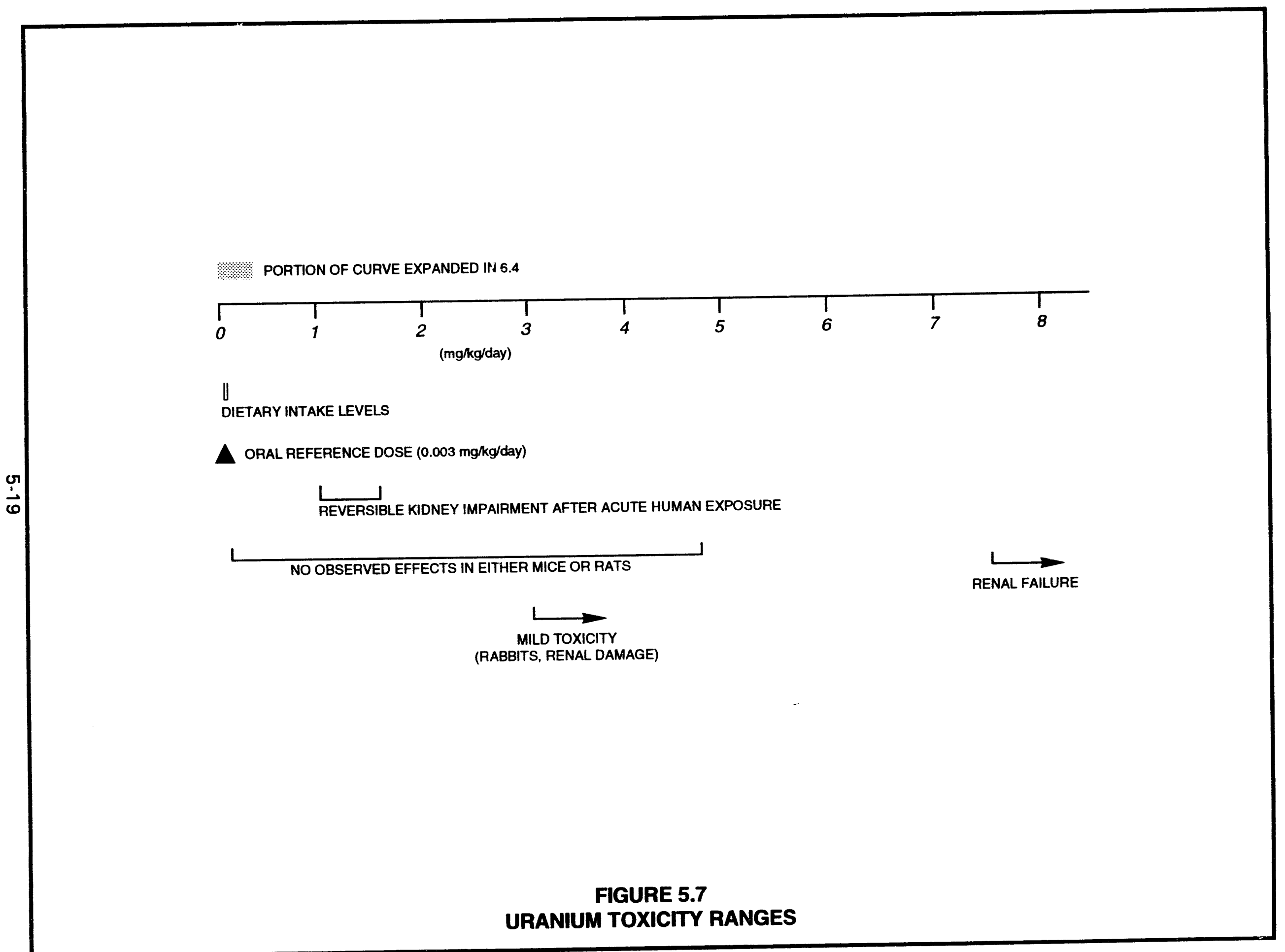


updated quarterly and published in the Health Effects Assessment Summary Tables (HEAST) and are also provided through the EPA's Integrated Risk Information System (IRIS) dula base. The most recent oral RfDs for the noncarcinogenic contaminants of concern are summarized in Table 5.1. RfDs for iron, cobalt, and sulfate have not been determined.

The EPA currently classifies all radionuclides as Group $A$, or known human carcinogens, based on their property of emitting ionizing radiation and on the evidence provided by epidemiological studies of radiation-induced cancer in humans. Risk factors are published in HEAST and IRIS for correlating intake of carcinogens over a lifetime with the increased excess cancer risk irom that exposure. The most recent cancer slope factors (SF) for the uranium-234/-238 radioactive decay series are given in Table 5.2 . 


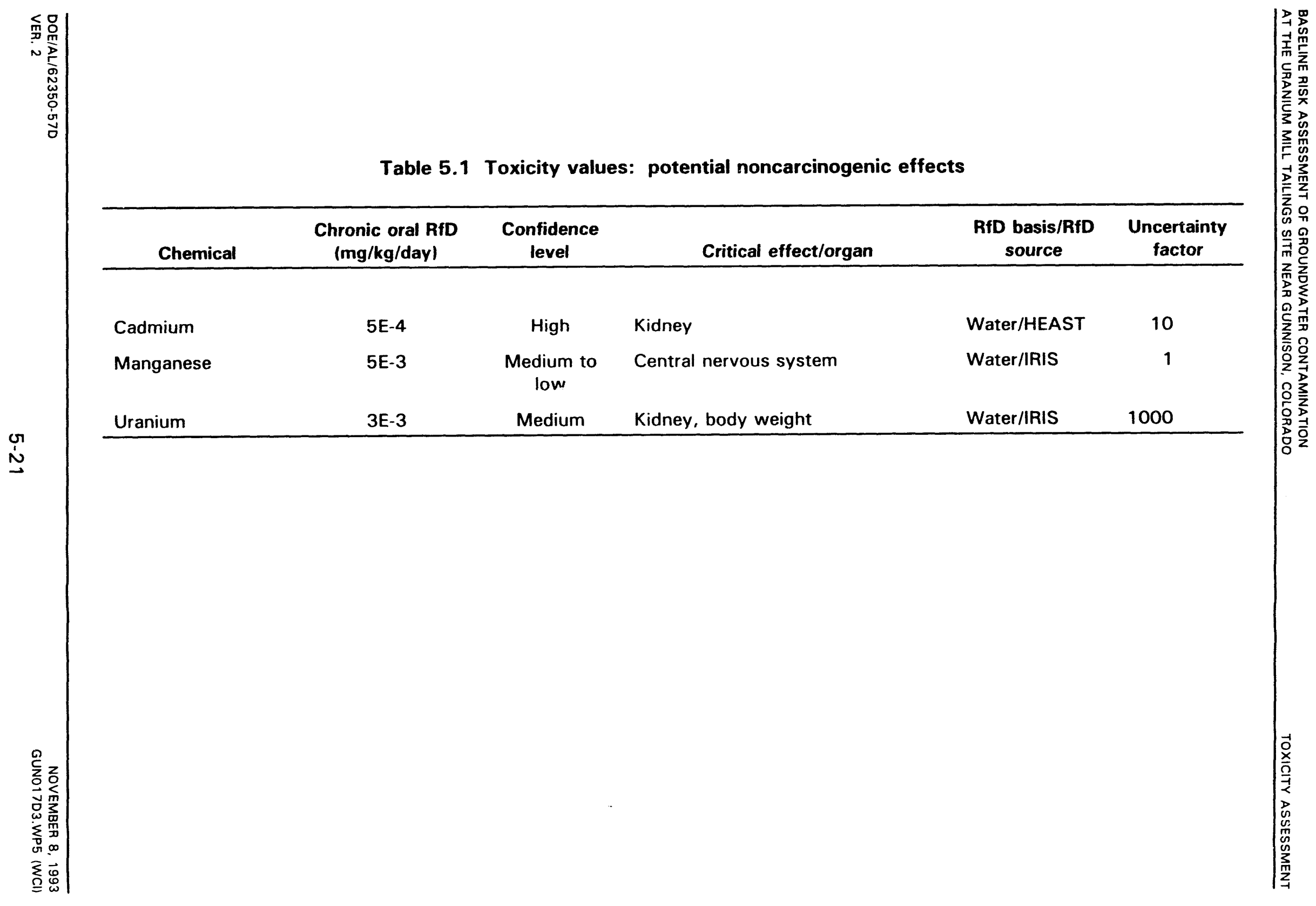


Table 5.2 Toxicity values: carcinogenic effects

\begin{tabular}{lcccc}
\hline \multicolumn{1}{c}{ Parameter } & $\begin{array}{c}\text { Oral SF } \\
(\mathbf{p C i})^{-1}\end{array}$ & $\begin{array}{c}\text { Weight of evidence } \\
\text { classification }\end{array}$ & Type of cancer & SF basis/SF source \\
\hline Lead-210 & $5.1 \mathrm{E}-10$ & A & Bone & Water/HEAST \\
Polonium-210 & $1.5 \mathrm{E}-10$ & $\mathrm{~A}$ & Liver, kidneys, spleen & Water/HEAST \\
Radium-226 & $1.2 \mathrm{E}-10$ & $\mathrm{~A}$ & Bone & Water/HEAST \\
Thorium-230 & $1.3 \mathrm{E}-11$ & $\mathrm{~A}$ & Bone & Water/HEAST \\
Uranium-238 & $1.6 \mathrm{E}-11$ & $\mathrm{~A}$ & Note $^{\mathrm{a}}$ & Water/HEAST \\
Uranium-234 & $1.6 \mathrm{E}-11$ & $\mathrm{~A}$ & Note $^{\mathrm{a}}$ & Water/HEAST \\
\hline
\end{tabular}

${ }^{a}$ No human or animal studies have shown a definite association between oral exposure to uranium and development of cancer. 


\subsection{RISK EVALUATION}

To evaluate human health risks to an individual or population, the results of the exposure assessment are combined with the results of the toxicity assessment. As discussed in Section 5.0, potential adverse health effects are a function of how much of the contaminant an individual takes into his or her body. Indeed, at lower levels many of the contaminants associated with the mill tailings are beneficial to health, since they are essential nutrients. At higher levels, these same elements can cause adverse health effects or, at very high levels, death. In this section, the expected intake, if groundwater within the plume were used as drinking water, is correlated to potential health effects from these levels of exposure.

\subsection{POTENTIAL NONCARCINOGENIC HEALTH EFFECTS}

The results from the exposure assessment showing either the highest intake-tobody-weight ratios (or highest doses) or the toxicologically most sensitive group are used to evaluate potential health effects for noncarcinogens. For the contaminants of concern at the Gunnison site, the highest intake-per-body-weight group is children 1 to 10 years old.

The primary concerns for human health from ingestion of contaminated groundwater at the Gunnison site are from exposure to iron and manganese. Greater than 50 percent of the potential exposure range for iron is above the dose that produces chronic iron toxicity, including pigmentation of the skin and potential disruption of liver and endocrine function (Figure 6.1). Long-term exposure to these concentrations of iron could also result in cirrhosis of the liver and/or development of diabetes. A very low percentage of the distribution exceeds the dose that produces acute severe poisoning in children.

For manganese, all of the potential exposure range is greater than the levels reported to produce early neurological signs of manganese toxicity, and greater than 50 percent of the distribution falls above levels that have been reported to produce Parkinson's-like effects following chronic exposure through drinking water (Figure 6.2).

Iron and manganese are known to interact by inhibiting the absorption of the opposite metal. However, the net effect of this interaction cannot be predicted with both metals in such high concentrations. Although the other pathways screened in Section 4.2 could contribute an additional 4 percent to the potential exposure from drinking contaminated water, this increase in the potential exposure would not significantly increase the risk over that predicted from the drinking water pathway alone.

The potential range of sulfate exposure from drinking contaminated groundwater is mostly above the range expected to produce mild toxicity ranging from laxative effects in adults to diarrhea in infants (Figure 6.3). Nearly 50 percent of the 


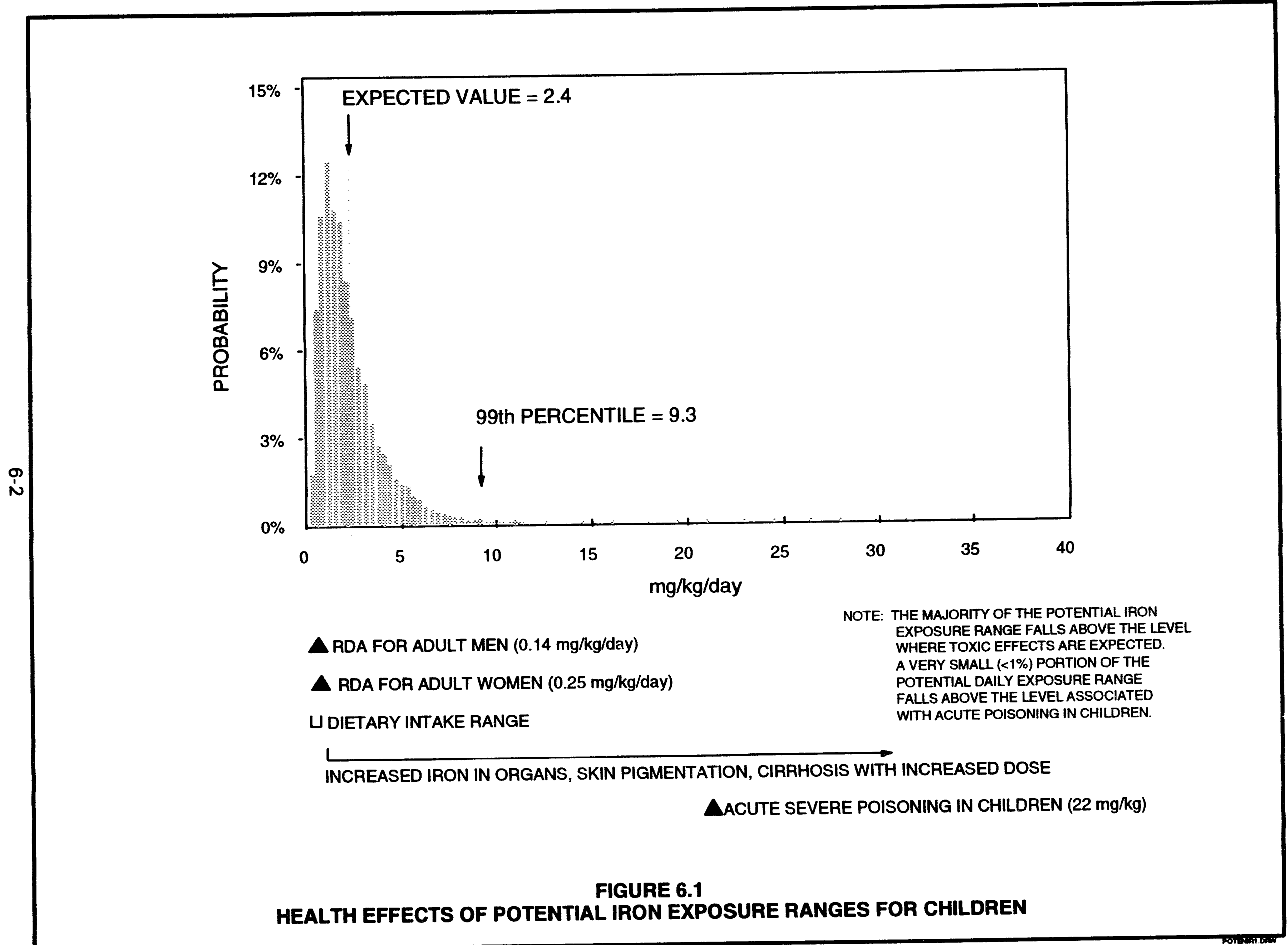




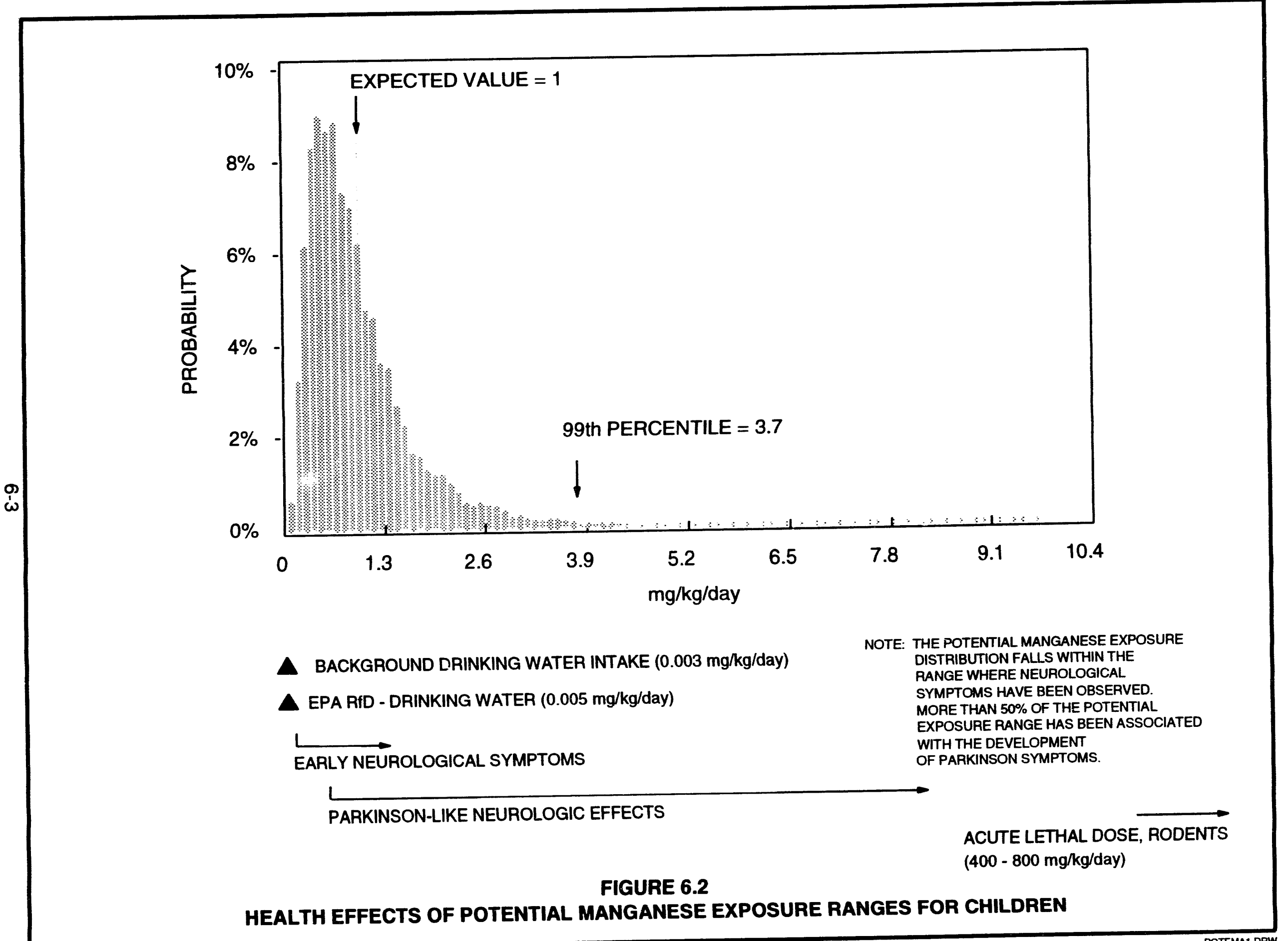




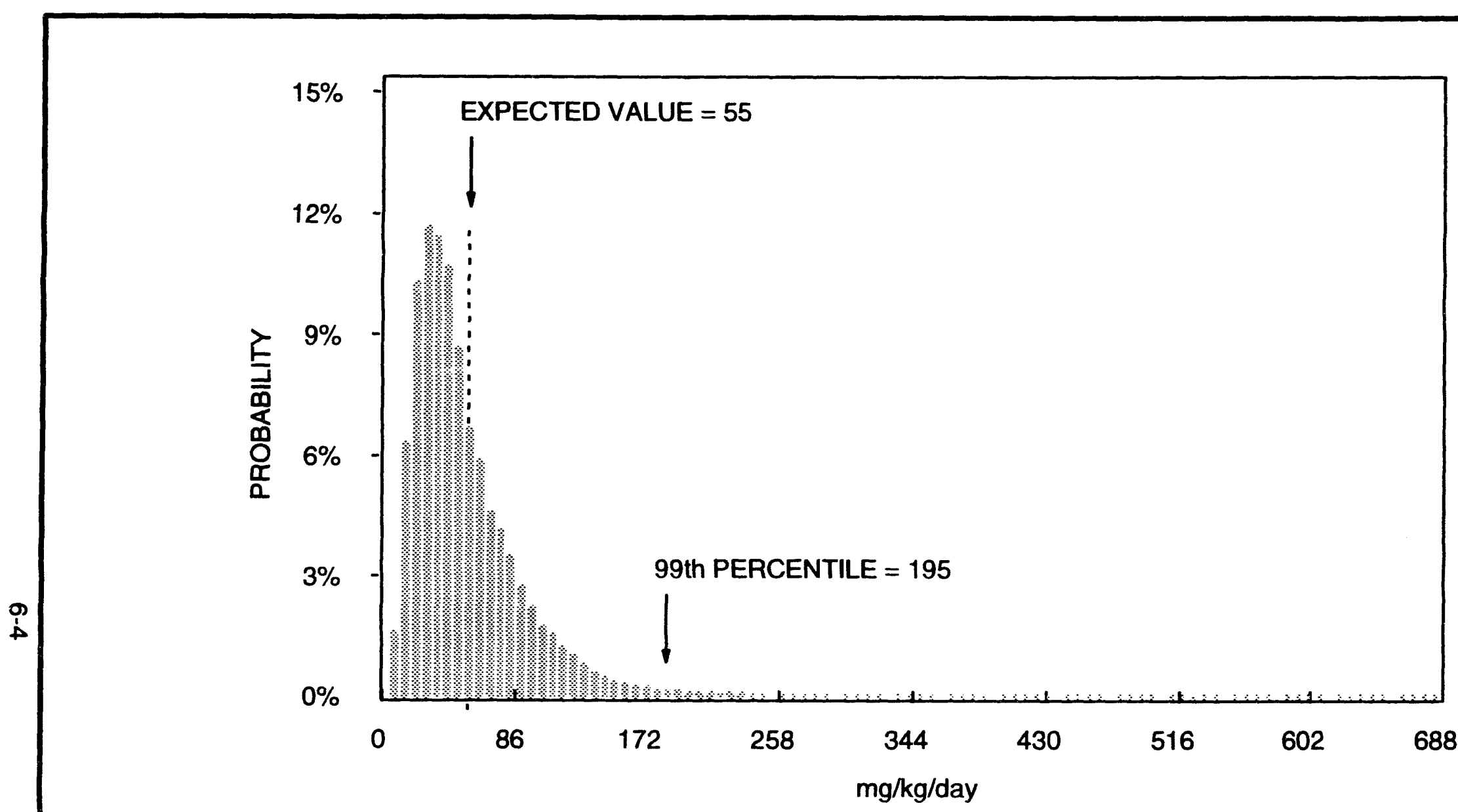

U BACKGROUND INT AKE LEVELS

NOTE: LAXATIVE EFFECTS MANIFESTED AS

DIARRHEA IN INFANTS COULD OCCUR WITHIN THE LOWER RANGE OF POTENTIAL EXPOSURES,

$\sqcup$ NO OBSERVED EFFECTS

WTH SEVERE DEHYDRATION IN INFANTS

OCCURRING AT HIGHER POTENTIAL EXPOSURES.

ᄂـ

MILD TOXICITY RANGING FROM LAXATIVE EFFECT (ADULTS) TO DIARRHEA IN INFANTS

SEVERE TOXICITY - PERSISTENT INFANT DIARRHEA LEADING TO DEHYDRATION $\cdots$ DEATH

FIGURE 6.3

HEALTH EFFECTS OF POTENTIAL SULFATE EXPOSURE RANGES FOR CHILDREN 
potential exposure range falls within the range of exposures that could result in severe persistent diarrhea in infants. As discussed in Section 5.1.5, the diarrhea resulting from the sulfate exposures could alter the excretion or reabsorption of manganese, although no data are available to evaluate this possibility. Sulfate exposure from the other pathways discussed in Section 4.2 is not expected to result in an increase in the risk over that from groundwater ingestion alone.

For the noncarcinogenic effects of uranium, the entire exposure distribution falls above the oral RfD, but below ranges resulting in adverse effects in animal studies (Figure 6.4). Animal data are not always predictive of human toxicity, however, and the lack of available human data to evaluate oral toxicity of uranium at these concentrations should not be seen as an indication that no toxic effects will occur. RfDs incorporate safety and uncertainty factors and therefore are generally conservative values designed to be protective of human health. However, they are based on careful evaluation of existing data bases; therefore, exposures that significantly exceed the RfD should be considered as potential problems. Reversible kidney damage has been reported in humans following acute exposures two times greater than the highest values in this simulated potential exposure distribution. The contribution of uranium exposure from the other pathways would be less than 1 percent of the drinking water pathway and again would not alter the interpretation of risk.

The ranges of potential exposures to cadmium (Figure 6.5) and cobalt (Figure 6.6) are both below any potential toxic effects. The addition of the approximately 7 percent contribution from other sources to the cadmium exposure and approximately 6 percent additional cobalt exposure (Section 4.2) would still not result in potentially toxic effects from these constituents.

\subsection{POTENTIAL CARCINOGENIC HEALTH EFFECTS}

All uranium isotopes are radioactive and, as such, are considered potential carcinogens. Table 6.1 presents estimates of the excess lifetime cancer risk predicted to result from ingestion of contaminated groundwater at the Gunnison site. These estimates are based on the cancer SFs developed by the EPA; however, natural uranium has not been demonstrated to cause cancer in humans or animals following ingestion exposures. The maximum estimates for lead-210 and uranium exceed the National Contingency Plan guidance for maximum increased lifetime cancer risk of $1 \times 10^{-4}$, as does the median estimate for uranium. Summing the risks calculated in Table 6.1 to one significant figure, median and maximum excess cancer risk estimates from groundwater ingestion of all radionuclides combined would be $3 \times 10^{-4}$ and $1 \times 10^{-3}$, respectively. The only decay product that contributes more than 1 percent from the other pathways in Section 4.2 is lead-210, with a contribution of approximately 3 percent. However, calculating risks to one significant figure, the additional contribution of lead-210 from other pathways does not increase the excess cancer risk estimate. 


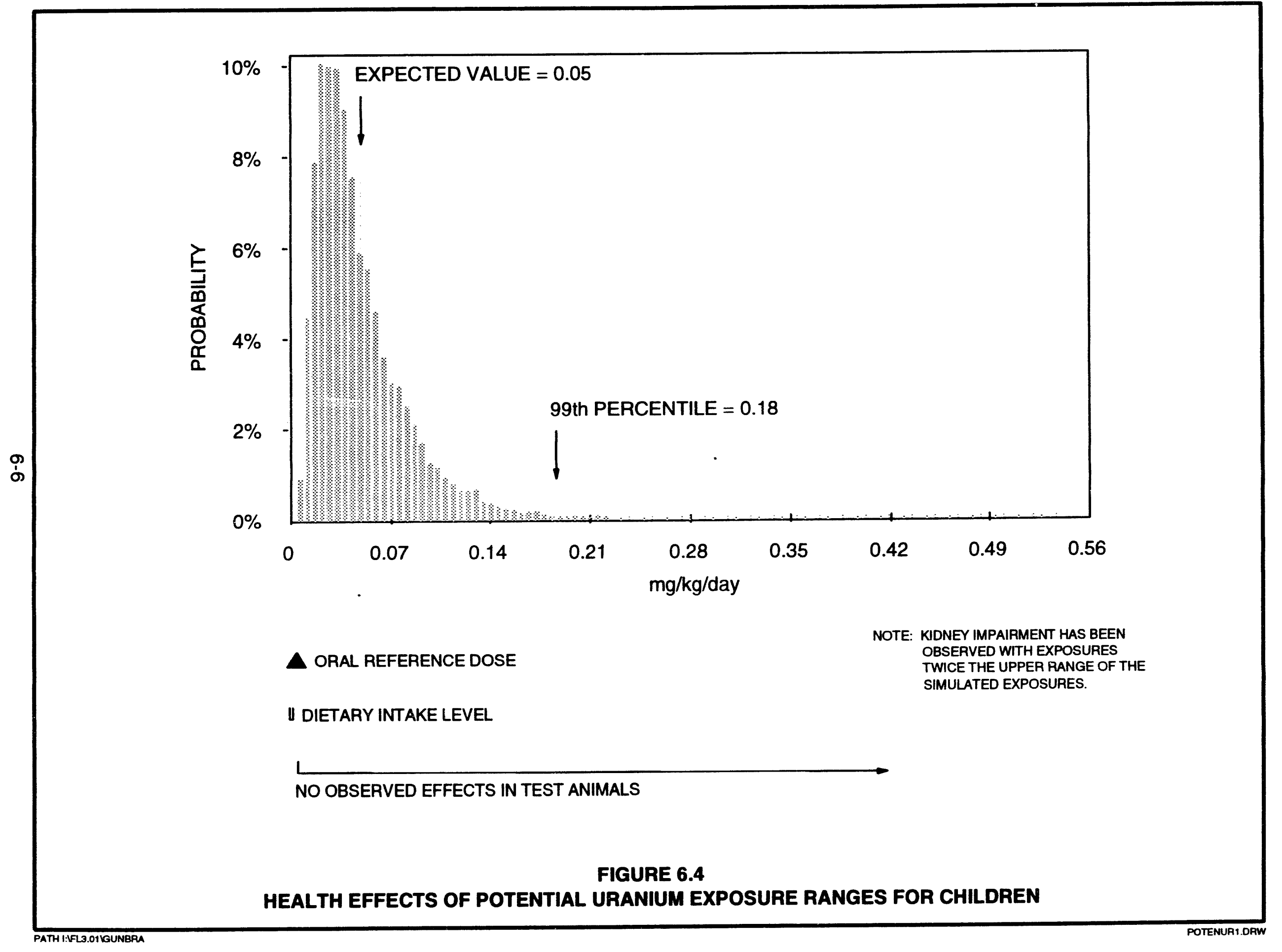




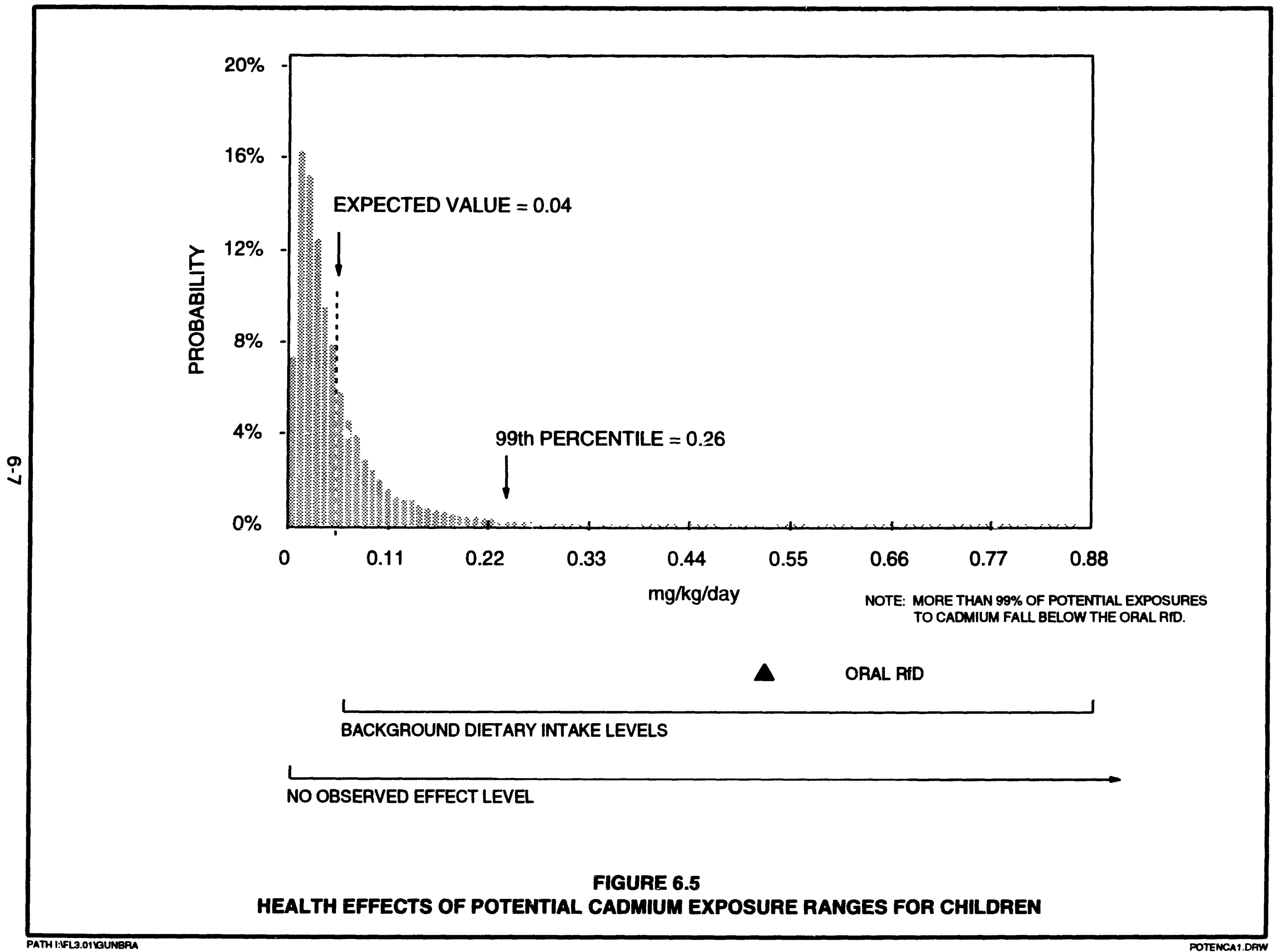




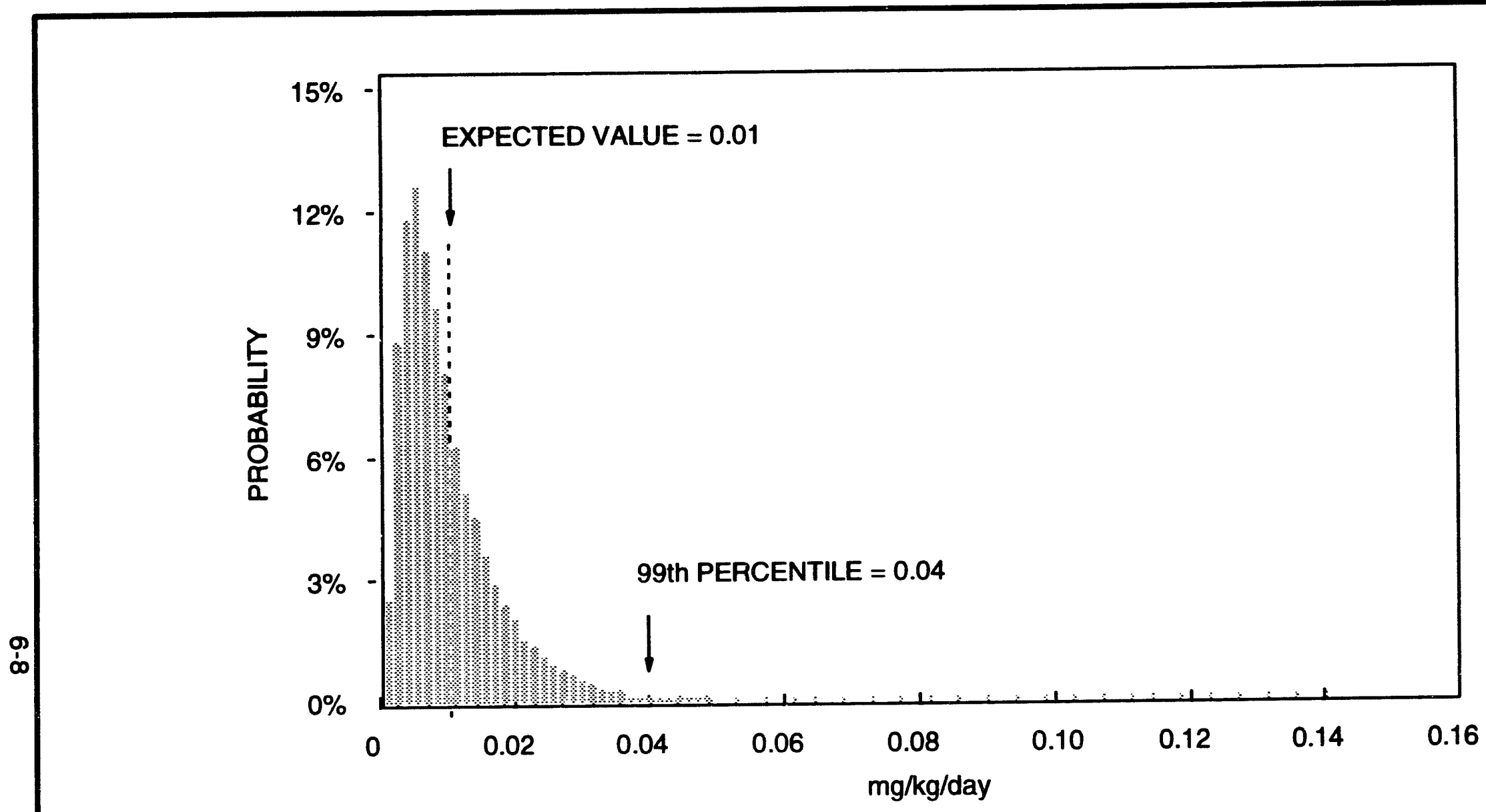

$\triangle$ NUTRITIONAL REQUIREMENT (0.0002 mg/kg/day)

NOTE: NO ADVERSE HEALTH EFFECTS HAVE BEEN ASSOCIATED WITH THE POTENTIAL EXPOSURE RANGE FOR COBALT.

BACKGROUND INTAKE FROM DRINKING WATER (0.003 mg/kg/day)

U DIETARY INTAKE $(0.00007-0.0006 \mathrm{mg} / \mathrm{kg} /$ day $)$

CARDIOMYOPATHY IN ADULT HUMANS

FIGURE 6.6

HEALTH EFFECTS OF POTENTIAL COBALT EXPOSURE RANGES FOR CHILDREN 
Table 6.1 Excess lifetime cancer risk calculations for groundwater ingestion by a hypothetical future adult resident, Gunnison UMTRA Project site, Gunnison Colorado

\begin{tabular}{|c|c|c|c|c|c|c|c|}
\hline \multirow[b]{2}{*}{$\begin{array}{c}\text { Contaminant of } \\
\text { concern }\end{array}$} & \multicolumn{2}{|c|}{$\begin{array}{c}\text { Concentration in } \\
\text { groundwater }\end{array}$} & \multicolumn{2}{|c|}{$\begin{array}{l}\text { Groundwater } \\
\text { exposure doses } \\
\text { (pCi per lifetime) }\end{array}$} & \multirow[b]{2}{*}{$\begin{array}{l}\text { Oral SF } \\
(\mathrm{pCi})^{-1}\end{array}$} & \multicolumn{2}{|c|}{$\begin{array}{l}\text { Excess lifetime } \\
\text { cancer risk }\end{array}$} \\
\hline & $\begin{array}{r}\text { Median } \\
1\end{array}$ & $\begin{array}{l}\text { Maximum } \\
\text {-i/L) }\end{array}$ & Median & Maximum & & Median & Maximum \\
\hline Lead-210 & 2.4 & 78 & $5.0 E+04$ & $1.6 \mathrm{E}+06$ & $5.1 E-10$ & $3 E-05$ & $8 E-04$ \\
\hline Polonium-210 & 0.4 & 1.6 & $8.4 E+03$ & $3.4 E+04$ & $1.5 \mathrm{E}-10$ & $1 \mathrm{E}-06$ & $5 \mathrm{E}-06$ \\
\hline Thorium-230 & 0.5 & 2.0 & $1.1 E+04$ & $4.2 E+04$ & $1.3 E-11$ & $1 E-07$ & $5 \mathrm{E}-07$ \\
\hline \multirow[t]{2}{*}{ Uranium $^{\mathrm{b}}$} & 960 & 1100 & $2.0 E+07$ & $2.3 E+07$ & $1.6 \mathrm{E}-11$ & 3E-04 & 4E-04 \\
\hline & & & & & Total: & 3E-04 & 1E-03 \\
\hline
\end{tabular}

aExcess lifetime cancer risk is calculated by multiplying the exposure dose by the SF.

buranium-234 and uranium-238 combined. The oral SF is the same for both isotopes. 


\subsection{LIVESTOCK AND ENVIRONMENTAL EVALUATION}

The objective of the environmental portion of the risk assessment is to determine whether contaminants detected at the site have the potential to adversely affect the existing biological community at or surrounding the site. Currently, the EPA has no guidance for quantifying potential impacts to ecological receptors but has developed a qualitative approach generally used for ecological evaluation (EPA, 1989b). With the qualitative approach, the EPA recommends that ambient environmental media concentrations be compared to water quality, sediment quality, or other relevant criteria to determine whether any of the concentrations that the ecological receptors are expected to encounter exceed these criteria.

Ecological assessments can be distinguished from human health assessments in that the nature of ecological relationships influences the impacts of constituents. Environmental toxicology, or ecotoxicology, combines the science of ecology and toxicology to study the ecological effects of environmental contaminants. Contaminants are defined as environmental constituents that occur at high enough concentrations to cause deleterious biological effects (Moriarty, 1988). Toxicology has focused largely on studying the effects of single compounds on individual organisms. In ecotoxicology, this must be extended to include effects of multiple constituents on the ecosystem.

An ecosystem is composed of both abiotic and biological components. The abiotic component is called the habitat. Biological components are organized into species, populations, and communities. A population is composed of individuals of a species that occur within a defined area, and a community is a collection of all populations (plant, animal, bacteria, and fungi) that live in a defined area and interact with one another. In practice, it is not always easy to set the boundaries for populations and communities. The community plus its habitat is an ecosystem (Moriarty, 1988).

The prediction of ecotoxicological effects from constituents is extremely complicated. Ecosystems are not static; the biological components experience constant fluctuations both in population numbers and relative composition. Abiotic factors (e.g., temperature, precipitation, nutrient availability, etc.) are also constantly changing. The stability of an ecosystem is therefore determined to a great extent by the ability to respond to "normal" stresses. The normal or baseline conditions are not well understood or defined for any ecosystem. Therefore, it is difficult to determine whether changes in ecological parameters (e.g., diversity, total biomass, reproductive trends, etc.) are associated with contaminants or merely reflect normal fluctuations.

It is possible that effects on individual organisms or even populations may not affect the ecosystem at all. If a prey species is affected, predators may be able to shift to feeding on other species; losses of predators may be compensated for by other predators or by immigration of another predator population. Recognizing when an adverse effect has occurred, or is occurring, is the challenge. Unless there is a mass killing within a population or community, effects may go unnoticed. Sublethal effects such as behavioral changes, reduced reproductive success, enzyme level changes, or effects on microorganisms can have an effect at the population or community level of organization 
due to an effect on reproductive success in one species that may influence other dependent species. It is often difficult to identify and measure the sublethal effects, and establishing a causal relationship to a specific environmental stressor, such is a specific contaminant, is only rarely accomplished. Evidence of sublethal effects and gross impacts were not observed during the field survey.

The effects of contaminants on ecological receptors are a concern; however, it is difficult to predict whether observed effects on individual populations will result in any damage to the ecosystem. Populations are dynamic; verefore, information concerning the normal range of variability within the population needs to be known. Sublethal effects, which may be very important to overall ecosystem health, are difficult to detect, and contaminants present at low concentrations may not kill organisms directly but may diminish their ability to survive and reproduce.

\subsection{EXPOSURE CHARACTERIZATION}

This section identifies the potential exposure pathways associated with the site. For risk to exist, a receptor must be exposed to contaminants. Exposure can occur only if there is both a source cf contamination and a mechanism of transport to a receptor population or individual.

Currently impacted media at the site include the tailings pile, associated contaminated soil, and groundwater. However, approximately 75 percent of the tailings pile and contaminated soil are scheduled to be removed from the processing site by the end of 1993. The remainder of the tailings pile and associated contaminated soil will be removed in the spring of 1994. Thus, direct exposure pathways (such as incidental ingestion of soil, dermal contact with soil, and inhalation of air containing particulates) will not represent a future ecological concern and will not be evaluated in this baseline risk assessment. However, direct exposure pathways (such as ingestion of surface water potentially affected by contaminated groundwater and bioconcentration of contaminants in surface water by aquatic organisms) and indirect exposure pathways (such as consumption of previously exposed organisms, known as bioaccumulation) are possible at the site.

The net accumulation by organisms of a constituent directly from the surrounding environment is known as bioconcentration. Net accumulation by organisms as a result of all routes of exposure, including the diet, is known as bioaccumulation. Generally, bioconcentration is measured for uptake of chemicals from water by aquatic organisms. BCFs for ingestion of, and dermal contact with, soils are too variable and dependent on site conditions to make identification of generic soil BCFs possible. Freshwater fish BCFs in the scientific literature for the contaminants of concern detected in surface waters in the site vicinity range from 30 liters per kilogram (L/kg) for strontium to $100 \mathrm{~L} / \mathrm{kg}$ for iron (NUREG, 1986; EPA, 1992). No fish BCFs were found in the available literature for calcium, fluoride, magnesium, manganese, potassium, silica, sodium, and sulfate. Identification of significant fish $B C F$ values have ranged from $1000 \mathrm{~L} / \mathrm{kg}$ down to $300 \mathrm{~L} / \mathrm{kg}$ (Kenaga, 1980; EPA, $1989 \mathrm{~b}$ ). None of the contaminants of concern that have BCFs (including iron, 
which was identified as a contaminant of potential concern for human health) wouid be identified as significant.

Surface water bodies in the site vicinity include the Gunnison River, Tomichi Creek, various ponds and ditches, and wetlands. The site lies equidistant $10.4 \mathrm{mi}$ $(0.6 \mathrm{~km})]$ between the Gunnison River and Tomichi Creek, with the river west of the site and the creek to the southeast. The confluence of the river and creek is approximately $1.5 \mathrm{mi}(2.4 \mathrm{~km})$ southwest of the site isee Figure 2.5$)$. Surface water runoff from the site flows to the south and east toward Tomichi Creek. The site is bounded on the west by drainage ditches and to the south and west by an irrigation ditch. Two ponds are located at the campground, which is approximately $200 \mathrm{ft}(60 \mathrm{~m})$ west, across Goodwin Lane from the tailings pile. The northernmost pond, which is nearest to the campground entry driveway, is fed by Gunnison River water from an irrigation ditch. This pond is used for pay fishing by campers and, according to the campground owner, the pond had been stocked with rainbow trout during the first week of June 1993. This pond is drained each winter and refilled in the spring. The rainbow trout used for stocking were provided by a state fish hatchery. The other pond located adjacent to the pay fishing pond is not stocked and receives surface runoff from the drainage ditch that runs under Goodwin Lane. Wetland areas are located at the western end of the site and along Gold Basin Road in the adjacent windblown area, which has been cleaned up.

All of these water bodies are potential exposure points for resident aquatic life and for terrestrial wildlife (including domestic animals) to come in contact with surface water and/or sediments. These exposure pathways were evaluated in this risk assessment.

Another potential curient pathway could involve plant uptake of contaminants in groundwater. Due to the shallow depth to groundwater lapproximately $5 \mathrm{ft}(1.5 \mathrm{~m})$ or less below land surfacel, plants can reach contaminated groundwater. Plant uptake was evaluated in this risk assessment assuming that the plant roots reached soil saturated with groundwater containing the mean concentrations for the most contaminated wells for the contaminants of concern.

Another potential pathway involves use of groundwater from an existing domestic well as a source of water for livestock or for agricultural activities. For the purposes of this baseline risk assessment, it was assumed as a conservative measure that a domestic well could, at some point in the future, intercept the most contaminated groundwater in the plume. The water from this hypothetical well could be used for a livestock watering pond (which could also be stocked with fish) or for irrigation of agricultural crops.

\subsection{ECOLOGICAL RECEPTORS}

This section identifies the ecological resources present at the site and vicinity that are potentially exposed to site-related contaminants. 
The following information on ecological receptors is based primarily on surveys done before the tailings removal process was initiated and is provided as a historical perspective. Limited observations of aquatic organisms were conducted at the surface water, sediment, and fish sampling locations during a June 23, 1993, field survey. No observations of terrestrial flora and fauna were conducted during these sampling activities. It is recommended that additional ecological characterization be conducted after remediation of the tailings pile is completed.

Most of the land within the site boundary was disturbed during milling operations. After operations ceased, the tailings pile was covered with soil and reseeded. The unexcavated pile is grass-covered; big sagebrush is scattered over most of the pile and reaches its maximum growth along the south, east, and west borders of the pile. The remainder of the designated site is currently being used by the Remedial Action Contractor as the operations center for remedial activities. This area of the site contains various office and laboratory trailers, a gravel parking lot, equipment storage, and a haul truck decontamination facility.

\subsubsection{Flora}

\section{Upland plant communities}

The processing site area is located within the Great Basin sagebrush habitat of the Southern Rocky Mountain zone. The processing site is in the floodplains of the Gunnison River and Tomichi Creek. The plant communities within the processing site area (including the adjacent windblown area) are indicative of the disturbed nature of the area.

Grasses and herbs predominate; an immature stand of cottonwoods grows at the western edge of the processing site.

\section{Desert shrub and shrub wetlands}

The plant communities in the windblown contaminated areas to the north and east of the site are desert shrub and shrub wetlands. Big sagebrush is the most common shrub species in the desert shrub community and grows as scattered individuals or in clumps (TAC, 1989). Rabbitbrush is also present, and grass and herbs are the dominant ground cover. Willow is the most common species in the wetland habitat and occurs in fairly dense stands in some areas. Small [5- to 15-ft (1.5- to 4.6-m)] narrowleaf cottonwood trees are also common in this area. The wetland habitat has dense grass as ground cover (TAC, 1989). 


\section{Wetland plant communities}

Approximately 8.1 ac (3.3 ha) of U.S. Army Corps of Engineers-designated wetlands are found in the western portion of the processing site and within windblown contamination areas east of the processing site (DOE, 1992b). Wetlands at the processing site consist of wet meadows dominated by grass, sedges, rushes, and herbs. Wetlands in the windblown-contaminated areas are shrub-dominated. A wet meadow-type wetland along the haul road is dominated by grass, sedges, and rushes.

\subsubsection{Terrestrial fauna}

Brief reconnaissance surveys for wildlife have been conducted in the processing site area. No reptiles or ar.nphibians were observed; however, "even species, including the short-horned lizard, eastern fence lizard, and bullsnake, would be expected at the site (Hammerson, 1986; CDM, 1981).

Amphibians would be most common in the flooded wetland areas where species such as tine leopard frog, boreal chorus frog, and tiger salamander may occur. Lizaid species such as the short-horned lizard and sagebrush lizard would be more common in the sagebrush habitat and disturbed tailings area (Hammerson, 1986; CDM, 1981).

A total of 43 species of birds have been observed during various site surveys (TAC, $1990,1989,1988,1986,1985 ;$ CDM, 1981). The western meadowlark, red-wing blackbird, yellow warbler, and robin were common nesting species at and near the tailings pile. Wetland species such as red-wing blackbirds, waterfowl, and shorebirds were common in the flooded hayfields. The sage thrasher, sage grouse, green-tailed towhee, and various species of sparrows were common nesting species in the sagebrush habitat.

A total of 25 species of mammals may occur at the processing site (Bernard and Brown, 1978). Muskrat signs were observed in wetland areas. Other species typical of the disturbed and sagebrush habitats would be the desert cottontail and striped skunk. Mammals typical of the irrigated wetland habitat that would be expected in the area include the masked shrew, western jumping mouse, and muskrat. Surveys in 1990 resulted in the observation of an active prairie dog town at the northern end of the tailings pile; 20 burrows were observed (TAC, 1990).

\section{Threatened and endangered species}

Consultation with the Fish and Wildlife Service (FWS) to determine threatened and endangered (T\&E) species and other species of concern began in 1985. This process resulted in six T\&E species, one species proposed for listing, and five Federal candidate species being identified as potentially occurring in the Gunnison area. Two endangered bird species may occur near the site. The bald eagle occurs

DOE/AL/62350-57D

VER. 2
NOVEMBER 8, 1993 GUN017D3.WP7 (WCI) 
in small numbers during the winter along the Gunnison River, while the whooping crane stops to feed in the wetlands along Tomichi Creek during the spring and fall migrations.

The black-footed ferret is closely associated with prairie dog towns. A small prairie dog town was found on the north end of the tailings pile. Because of the highly disturbed nature of the area and small size of the town, it is unlikely that any blackfooted ferrets would be present.

Of the three endangered fish species (Colorado squawfish, humpback chub, bonytail chub) and one proposed fish species (razorback sucker), only the Colorado squawfish occurs in the Gunnison River. However, this species does not occur in the river in the Gunnison area.

Five Federal candidate species occur in the Gunnison area. The white-faced ibis and long-billed curlew occur in the wetland habitat along Tomichi Creek during migration; the snowy plover does not occur or occurs very sporadically in the Gunnison area. All potentially disturbed areas were surveyed for the presence of the skiff milkvetch and Gunnison milkvetch. No skiff milkvetch plants were found in any potentially disturbed areas; however, between 50 and 75 Gunnison milkvetch plants were found growing on the western side of the tailings pile in 1990. A subsequent survey in 1991, however, identified only two plants present (EES, 1991; TAC, 1990; Carlson, 1989).

Additional details on T\&E species are provided in Attachment 2, Biological Assessment, of the Environmental Assessment of Remedial Action at the Gunnison Uranium Mill Tailings Site Near Gunnison, Colorado (DOE, 1992b).

\subsubsection{Aquatic organisms}

No quantitative surveys of aquatic organisms occurring in the surface water bodies located in the vicinity of the site have been conducted to date as part of the TAC investigation (DOE, 1990; 1992b). The observations made during the field survey were focused on the water bodies from which samples were collected (i.e., the Gunnison River, Tomichi Creek, and the campground pond); thus, no observations were made in the wetland areas. Extremely high water levels, turbidity, and rapid velocity of the Gunnison River and Tomichi Creek acted to greatly limit visibility and observations of aquatic organisms. Other than some stonefly (Plecoptera) nymphs, caddis fly larvae (Trichoptera), and fly larvae (Diptera), no other aquatic organisms were observed in the Gunnison River and Tomichi Creek. In the Gunnison River, an approximately 3/4-pound (340-gram) brook trout was caught at location 775 and an approximately $11 / 4$-pound $(570$-gram) rainbow trout was caught at location 776. One brook trout and one German brown trout, each approximately $1 / 3$-pound (150 grams), were caught in Tomichi Creek at location 777. No fishing was conducted at location 778 . 
At the campground pond, location 779, water striders (Gerridae), adult water beetles (Coleoptera), and some fly larvae (Diptera) were observed. One rainbow trout, approximately 1 pound (450 grams), was collected from the pond during the June 23, 1993, sampling activities.

In addition to the fish species collected during the sampling activities, several other fish species are known to occur in the Gunnison River and Tomichi Creek, including kokonee and cutthroat trout, speckled dace, flannelmouth sucker, western white sucker, bluehead sucker, and bluehead $x$ flannelmouth sucker hybrid [Colorado Division of Wildlife (CDW, 1993)].

\subsection{CONTAMINANTS OF ECOLOGICAL CONCERN}

The complete list of groundwater contaminant levels that exceed background levels (Table 3.2, column 1) was used as the list of contaminants of potential concern for ecological receptors potentially exposed to groundwater (e.g., plant uptake). This list is composed of 16 nonradionuclides, plus lead-210, polonium-210, and thorium230.

The list of contaminants of potential concern in the surface water bodies was developed from the list of contaminants detected above background levels in groundwater (Table 3.2). This list of contaminants was then compared with the surface water data. Table 7.1 presents the surface water data for those contaminants detected in the surface water samples and above background levels in groundwater.

If a contaminant was never detected in the water body (e.g., ammonium, cadmium, cobalt, nickel, thorium-230, uranium) or the concentration detected downstream of the site was less than or equal to the concentration upstream of the site (the background level), then it was excluded as a contaminant of concern for ecological receptors. Additionally, silica in the Gunnison Kiver and calcium and magnesium in Tomichi Creek are excluded as contaminants of potential concern, because the differences between the downstream and upstream concentrations were minimal $1<10$ percent) and these constituents are not considered site-related contaminants. Although there was no background location specific to the campground pond, as there was for the Gunnison River and Tomichi Creek, concentrations detected in the pond water were compared to concentrations detected at the upstream locations in the river and creek. If a concentration detected in the pond water was less than or equal to the upstream concentration in the river and/or the creek, then it was eliminated as a contaminant of concern for the pond.

The concentrations used in these comparisons to background were from filtered samples for most of the constituents. Data from filtered samples were used because the majority of the state of Colorado's water quality standards are stated as dissolved (filtered) metal concentrations. Unfiltered data were used for iron because the water quality criterion for this metal is based on the total recoverable (unfiltered) metal concentration. 
Table 7.1 Occurrence of constituents detected in surface water bodies located in the site vicinity, Gunnison UMTRA Project site, Gunnison, Colorado

\begin{tabular}{|c|c|c|c|c|c|}
\hline \multirow[b]{2}{*}{ Constituent } & \multicolumn{2}{|c|}{$\frac{\text { Gunnison River }}{\text { Location ID }}$} & \multicolumn{2}{|c|}{$\frac{\text { Tomichi Creek }}{\text { Location ID }}$} & \multirow{2}{*}{$\begin{array}{c}\frac{\text { Campground Pond }}{\text { Location ID }} \\
779 \\
\end{array}$} \\
\hline & $\begin{array}{c}775 \\
\text { (Upstream) }\end{array}$ & $\begin{array}{c}776 \\
\text { (Downstream) } \\
\end{array}$ & $\begin{array}{c}778 \\
\text { (Upstream) }\end{array}$ & $\begin{array}{c}777 \\
\text { (Downstream) }\end{array}$ & \\
\hline Calcium & 32 & 32 & 44 & 48 & 44 \\
\hline Fluoride & 0.2 & 0.1 & 0.3 & 0.3 & 0.2 \\
\hline Iron $^{a}$ & 0.07 & 0.06 & 0.3 & NA & 0.43 \\
\hline Magnesium & 6.6 & 6.5 & 10.4 & 11.3 & 9.6 \\
\hline Manganese & 0.01 & 0.01 & 0.05 & 0.05 & $<0.01$ \\
\hline Potassium & 0.85 & 0.82 & 2.2 & 2.1 & 1.7 \\
\hline Silica & 9.1 & 9.3 & 22 & 19 & 10 \\
\hline Sodium & 3.0 & 3.2 & 8.5 & 7.9 & 3.8 \\
\hline Strontium & 0.1 & 0.1 & 0.2 & 0.2 & 0.17 \\
\hline Sulfate & 18 & 16 & 17 & 24 & 12 \\
\hline Zinc & $<0.005$ & $<0.005$ & $<0.005$ & $<0.005$ & 0.04 \\
\hline
\end{tabular}

${ }^{a}$ Concentrations presented are from unfiltered samples collected in October 1990.

All concentrations reported in milligrams per liter from filtered samples collected in August 1989, unless specified otherwise.

NA - Unfiltered data not available.

After these comparisons were made, the following contaminant of potential concern was selected for Tomichi Creek: sulfate. For the campground pond, the contaminants of potential concern are iron and zinc. None of the constituents detected in downstream Gunnison River water are considered contaminants of potential concern.

No sediment samples were collected from the surface water bodies prior to the June 1993 sampling. Thus, the list of contaminants of potential concern includes those metals that were analyzed for in the sediment samples: manganese, molybdenum, uranium, and zinc.

\subsection{POTENTIAL IMPACTS TO WILDLIFE AND PLANTS}

\subsubsection{Terrestrial risk}

A potential exposure pathway that was evaluated involves terrestrial vegetation. Terrestrial vegetation can be directly exposed to contaminants in groundwater 
through uptake by the roots. Contaminants may bioaccumulate in various plant parts and exert a wide range of influences, depending on the specific contaminant. Plant uptake rates vary greatly among species and are affected by factors such as soil characteristics $(\mathrm{pH}$, moisture, redox potential, organic matter, etc.), plant sensitivity, input-output balance, and cumulative effects. Foraging Idlife can be indirectly exposed to contaminants in groundwater by ingesting plants that may have bioaccumulated certain contaminants. Terrestrial wildlife can be directly exposed to contaminants in surface water bodies by ingesting the surface water, aquatic organisms, and sediments. However, good information on generic BCFs for terrestrial wildlife is currently not available in the scientific literature.

Based on the shallow depth to contaminated groundwater at the site, it is possible that some plants could have rooting zones in soils that intercept contaminated groundwater.

Concentrations of the contaminants of concern in plant tissue were estimated using soil-to-plant BCFs. No soil data are available for the site, nor are water-to-plant BCFs available. However, because plants require nutrients to be in an aqueous form for root uptake, it was considered appropriate to use the soil-to-plant BCFs for estimating potential plant uptake at the site. Soil concentrations in the saturated zone were estimated by multiplying the groundwater concentration by the soilwater distribution coefficient, $\mathrm{Kd}$. The methodology and parameters used to estimate root uptake and plant tissue concentrations for the contaminants of concern are presented in Table 7.2. This methodology is described in detail elsewhere in the literature (Baes et al., 1984) and therefore will not be presented here.

The estimated tissue concentrations for the contaminants of concern in the vegetative portions (e.g., stems, leaves) and in the nonvegetative portions (e.g., fruits, tubers) were compared to approximate concentrations (in mature leaf tissue) that have been reported to be toxic to plants (phytotoxic) (Table 7.2). As illustrated in Table 7.2, few available data relate tissue concentrations to phytotoxicity. The reported phytotoxic concentrations are not representative of very sensitive or highly tolerant plant species. The estimated tissue concentrations for the contaminants of concern in plants that may reach soil saturated with contaminated groundwater do not exceed the available phytotoxicity data. No comparison data were available for calcium, iron, lead-210, magnesium, polonium210, potassium, silica, sodium, strontium, sulfate, thorium-230, and uranium. Thus, it is not possible to evaluate whether the estimated tissue concentrations could result in adverse effects to plants.

Bioaccumulation in terrestrial organisms as a function of contaminants of concern in ingested plants or animals (e.g., birds eating fish) is a potential exposure pathway at the site. Birds and other vertebrates consuming these plants and animals can bioaccumulate some of the contaminants of concern from this diet if the amount ingested exceeded the amount eliminated. This is often a function of the areal extent of contamination versus the areal extent of the animals feeding range. In the case of small contaminated areas, the amount of food in the diet usually 


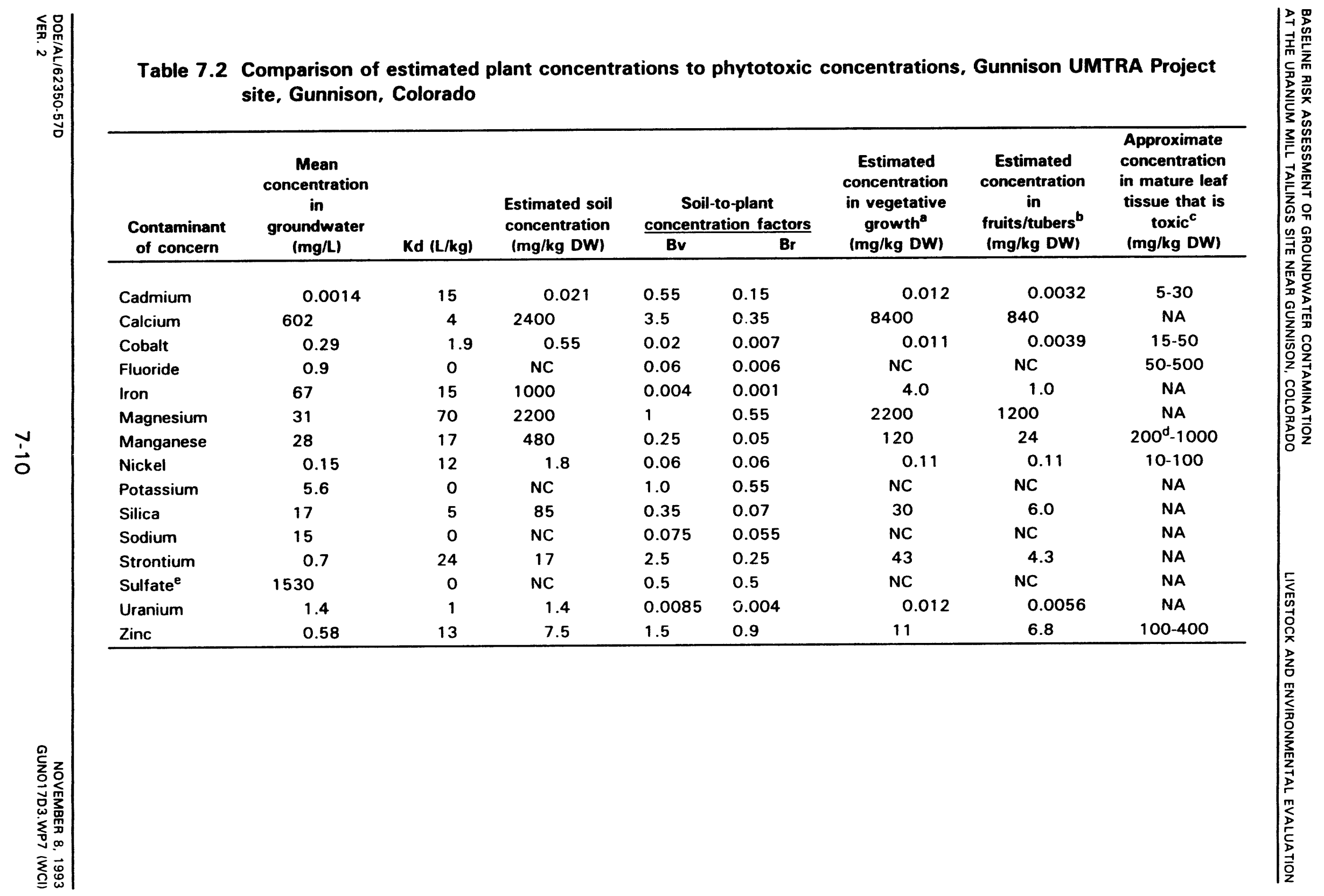


Table 7.2 Comparison of estimated plant concentrations to phytotoxic concentrations, Gunnison UMTRA Project site, Gunnison, Colorado (Concluded)

\begin{tabular}{|c|c|c|c|c|c|c|c|c|}
\hline \multirow{2}{*}{$\begin{array}{c}\text { Contaminant } \\
\text { of concern }\end{array}$} & \multirow{2}{*}{$\begin{array}{c}\text { Mean } \\
\text { concentration } \\
\text { in } \\
\text { groundwater } \\
\text { (mg/L) }\end{array}$} & \multirow[b]{2}{*}{$\mathrm{Kd}(\mathrm{L} / \mathbf{k g})$} & \multirow{2}{*}{$\begin{array}{l}\text { Estimated soil } \\
\text { concentration } \\
\text { (mg/kg DW) }\end{array}$} & $\begin{array}{r}\text { Soil-t } \\
\text { concentra }\end{array}$ & $\begin{array}{l}\text {-plant } \\
\text { ion factors }\end{array}$ & \multirow[t]{2}{*}{$\begin{array}{c}\text { Estimated } \\
\text { concentration } \\
\text { in vegetative } \\
\text { growth } \\
\text { (mg/kg DW) }\end{array}$} & \multirow[t]{2}{*}{$\begin{array}{c}\text { Estimated } \\
\text { concentration } \\
\text { in } \\
\text { fruits/tubers } \\
\text { (mg/kg DW) }\end{array}$} & \multirow[t]{2}{*}{$\begin{array}{c}\text { Approximate } \\
\text { concentration } \\
\text { in mature leaf } \\
\text { tissue that is } \\
\text { toxic } \\
\text { (mg/kg DW) }\end{array}$} \\
\hline & & & & Bv & $\mathrm{Br}$ & & & \\
\hline \multicolumn{9}{|l|}{ Radionuclides } \\
\hline Lead-210 & $1.6 \mathrm{E}-10$ & 230 & 3.7E-08 & 0.045 & 0.009 & 1.7E-09 & 3.3E-10 & NA \\
\hline Polonium-210 & 1.1E-13 & 5.9 & $6.5 E-13$ & 0.0025 & 0.0004 & $1.6 \mathrm{E}-15$ & $2.6 E-16$ & NA \\
\hline Thorium-230 & 4.5E-08 & 100 & $4.5 \mathrm{E}-06$ & 0.00085 & 0.000085 & $3.8 \mathrm{E}-09$ & $3.8 \mathrm{E}-10$ & NA \\
\hline
\end{tabular}

aEstimated concentration in vegetative portions, calculated as estimated soil concentration multiplied by Bv.

bestimated concentration in nonvegetative portions, calculated as estimated soil concentration multiplied by $\mathrm{Br}$.

c Concentrations are not presented for very sensitive or for highly tolerant plant species (Kabata-Pendias and Pendias, 1992).

The value of $200 \mathrm{mg} / \mathrm{kg}$ is a recommended criterion of the Illinois Institute of Environmental Quality (Saric, 1986).

$\mathrm{B}$ Bv and $\mathrm{Br}$ factors available for elemental sulfur only; thus, these factors were reduced by a factor of 3 for sulfate.

${ }^{\mathrm{f}}$ The groundwater concentration in $\mathrm{pCi} / \mathrm{L}$ was converted to $\mathrm{mg} / \mathrm{L}$.

Kd - soil-water distribution coefficient; from PNL, 1989, except for uranium and calcium. The Kd for uranium is a site-specific value. No Kd for calcium is available in PNL, 1989; Kd shown is from Baes et al. (1984).

Bv - soil-to-plant elemental transfer factor for vegetative portions of food crops and feed plants (Baes et al., 1984).

$\mathrm{Br}$ - soil-to-plant elemental transfer factor for nonvegetative portions (e.g., fruits, tubers), of food crops and feed plants (Baes et al., 1984 ).

DW - dry weight.

$\mathrm{mg} / \mathrm{kg}$ - milligrams per kilogram.

$\mathrm{mg} / \mathrm{L}$ - milligrams per liter.

L/kg - liters per kilogram.

NA - not available.

NC - value cannot be calculated because $K d$ is zero.

No $\mathrm{Kd}, \mathrm{Bv}$, or $\mathrm{Br}$ values available for ammonium. 
exceeds the impacted food, and bioaccumulation is not a concern. Therefore, exposure via the diet for all trophic level species is possible in certain areas le.g., wetland areas), but the potential for bioaccumulation is not always a concern. While it is realized that predators of fish would be exposed to concentrations present in the entire body, as opposed to concentrations in the muscle tissue, the primary purpose of the fish sampling conducted in June 1993 was to evaluate potential human health risk from ingestion of fish.

Biomagnification is a more severe situation in which the concentration of a constituent increases in higher levels of the food chain because the contaminant concentrations are accumulated through each successive trophic level. Of particular concern for biomagnification effects are the top predators, especially the carnivorous birds and mammals. Only a limited number of constituents have the potential for magnifying in the food chain. Most constituents are metabolized in organisms and eliminated at each level of the food chain. Thus, the constituent concentration does not increase up the food chain. Historically, the constituents of greatest biomagnification concern have been the organochlorine pesticides, mercury, polychlorinated biphenyls, and dioxins. None of these constituents were detected in media at the site. Based on available information, the potential for the detected contaminants of concern to represent a concern via food chain transfer is probably low.

To evaluate the potential impact that use of contaminated groundwater in a livestock pond might have on wildlife (i.e., animals drinking from the pond or fish stocked in the pond), the mean groundwater concentrations for the contaminants of concern were compared to available comparison water quality criteria (Table 7.3). There are no available Federal or state criteria or standards established for the protection of terrestrial wildlife via water exposure. Therefore, it is difficult to evaluate the potential hazards to terrestrial receptors without additional information. However, available surface water quality values for the protection of freshwater aquatic life do exist and include the state of Colorado standards $(C D H, 1991)$.

The mean groundwater concentrations for iron and manganese exceeded the comparison water quality values (Table 7.3), while the groundwater concentrations for cadmium, nickel, thorium-230, and zine were below the comparison values. The concentrations for iron and manganese exceed the state standards, indicating that this water would be unacceptable for aquatic organisms. No comparison water quality values are available for ammonium, calcium, cobalt, fluoride, lead-210, magnesium, polonium-210, potassium, silica, sodium, strontium, sulfate, and uranium.

Another future hypothetical use of the groundwater in the area is for irrigating agricultural crops. Table 7.3 compares the approximate concentrations in water used for irrigation purposes that should be protective of plants with the groundwater concentrations (EPA, 1972). Seven of the contaminants of concern cadmium, cobalt, fluoride, iron, manganese, nickel, and zinc - have comparison criteria. The mean groundwater concentrations for cobalt, iron, and manganese exceed the comparison criteria, while the concentrations of cadmium, fluoride, 
Table 7.3 Comparison of contaminants of potential concern in groundwater with available water quality values, Gunnison UMTRA Project site, Gunnison, Colorado

\begin{tabular}{|c|c|c|c|c|}
\hline Contaminant & $\begin{array}{c}\text { Mean } \\
\text { concentration in } \\
\text { groundwater }\end{array}$ & $\begin{array}{l}\text { Aquatic life water } \\
\text { quality value }\end{array}$ & $\begin{array}{c}\text { Water } \\
\text { concentration } \\
\text { protective of } \\
\text { livestock }^{\mathbf{b}}\end{array}$ & $\begin{array}{c}\text { Concentration in } \\
\text { irrigation water } \\
\text { protective of } \\
\text { plants }^{b}\end{array}$ \\
\hline Ammonium & 0.5 & NA & NA & NA \\
\hline Cadium & 0.0014 & $0.010^{c}$ & 0.05 & 0.01 \\
\hline Calcium & 602 & NA & NA & NA \\
\hline Cobalt & 0.29 & NA & 1.0 & 0.05 \\
\hline Fluoride & 0.9 & NA & 2.0 & 1.0 \\
\hline Iron & 67 & 1.0 & NA & 5.0 \\
\hline Lead-210 & $13 \mathrm{pCi} / \mathrm{L}$ & NA & NA & NA \\
\hline Magnesium & 31 & NA & NA & NA \\
\hline Manganese & 28 & 1.0 & NA & 0.20 \\
\hline Nickel & 0.15 & $0.80^{c}$ & NA & 0.20 \\
\hline Polonium-210 & $0.5 \mathrm{pCi} / \mathrm{L}$ & NA & NA & NA \\
\hline Potassium & 5.6 & NA & NA & NA \\
\hline Silica & 17 & NA & NA & NA \\
\hline Sodium & 15 & NA & NA & NA \\
\hline Strontium & 0.7 & NA & $N A$ & NA \\
\hline Sulfate & 1530 & NA & $1000^{d}$ & NA \\
\hline Thorium-230 & $0.9 \mathrm{pCi} / \mathrm{L}$ & $60 \mathrm{pCi} / \mathrm{L}$ & NA & NA \\
\hline Uranium & 1.4 & $32^{c}$ & NA & NA \\
\hline Zinc & 0.58 & $1.1^{\mathrm{c}}$ & 25 & 2.0 \\
\hline
\end{tabular}

${ }^{a}$ Value obtained from the Basic Standards and Methodologies for Surface Water, 3.1.0

(5 CCR 1002-8), Colorado Department of Health, Water Quality Control Commission (CDH, 1991), unless specified otherwise. These values are standards protective of aquatic life via chronic exposure. bFrom EPA (1972), unless specified otherwise. Values shown are for water used continuously on all soils.

'Water hardness-related state standard (CDH, 1991). Criterion presented was calculated using the mean hardness $(1630 \mathrm{mg} / \mathrm{L})$ determined from concentrations of calcium and magnesium in plume wells 006. 133, and 134 .

dfFrom National Research Council (1971).

Concentrations reported in milligrams per liter unless otherwise noted.

NA - not available. 
nickel, and zinc are below the comparison criteria. No comparison criteria are available for the remainder of the contaminants of concern. Thus, it is not possible to evaluate the potential for these compounds to adversely affect plants when applied in irrigation water.

Based on the available information, use of the alluvial groundwater near the site (containing the mean concentrations) as a continuous source of irrigation water may result in deleterious effects to crops, primarily due to the elevated concentrations of cobalt, iron, and manganese.

\subsubsection{Aquatic risk}

Surface water (unfiltered) and surficial sediment [0 to 4 in $(0$ to $10 \mathrm{~cm})]$ samples were collected from the Gunnison River upstream (location 775) and downstream (location 776) of the site, from Tomichi Creek upstream (location 778) and downstream (location 777) of the site, and from the campground pond (location 779) (Figure 3.11) on June 23, 1993. The surface water samples were analyzed for calcium, magnesium, manganese, molybdenum, uranium, and zinc; the sediment samples were analyzed for manganese, molybdenum, uranium, and zinc.

No samples of surface water or sediment have been collected to date from the wetland areas in the site vicinity.

\section{Gunnison River water}

A potential exposure point is the Gunnison River in the vicinity of the site. The plume of contaminated alluvial groundwater is believed to be discharging to the river, Tomichi Creek, and possibly the campground pond. The comparison of the surface water data collected from the river at the upstream location (location 775) versus the downstream location (location 776) that was conducted as part of the selection process for the contaminants of ecological concern (Section 7.3) indicated that most of the constituents did not exceed background concentrations. This suggests that groundwater discharge to the river has not affected the water quality, though the limited sampling is not conclusive.

\section{Gunnison River sediments}

There are no established state or Federal sediment quality criteria (SOC) for the protection of aquatic life for the contaminants of potential concern at this site (EPA, 1988).

The EPA is evaluating a methodology based on the three-phase sorption model for free metal ion activity and is assessing its applicability for determining the bioavailable fraction within sediments (EPA, 1989c). Currently, a number of other predictive models and methods are being investigated for metals, but no single 


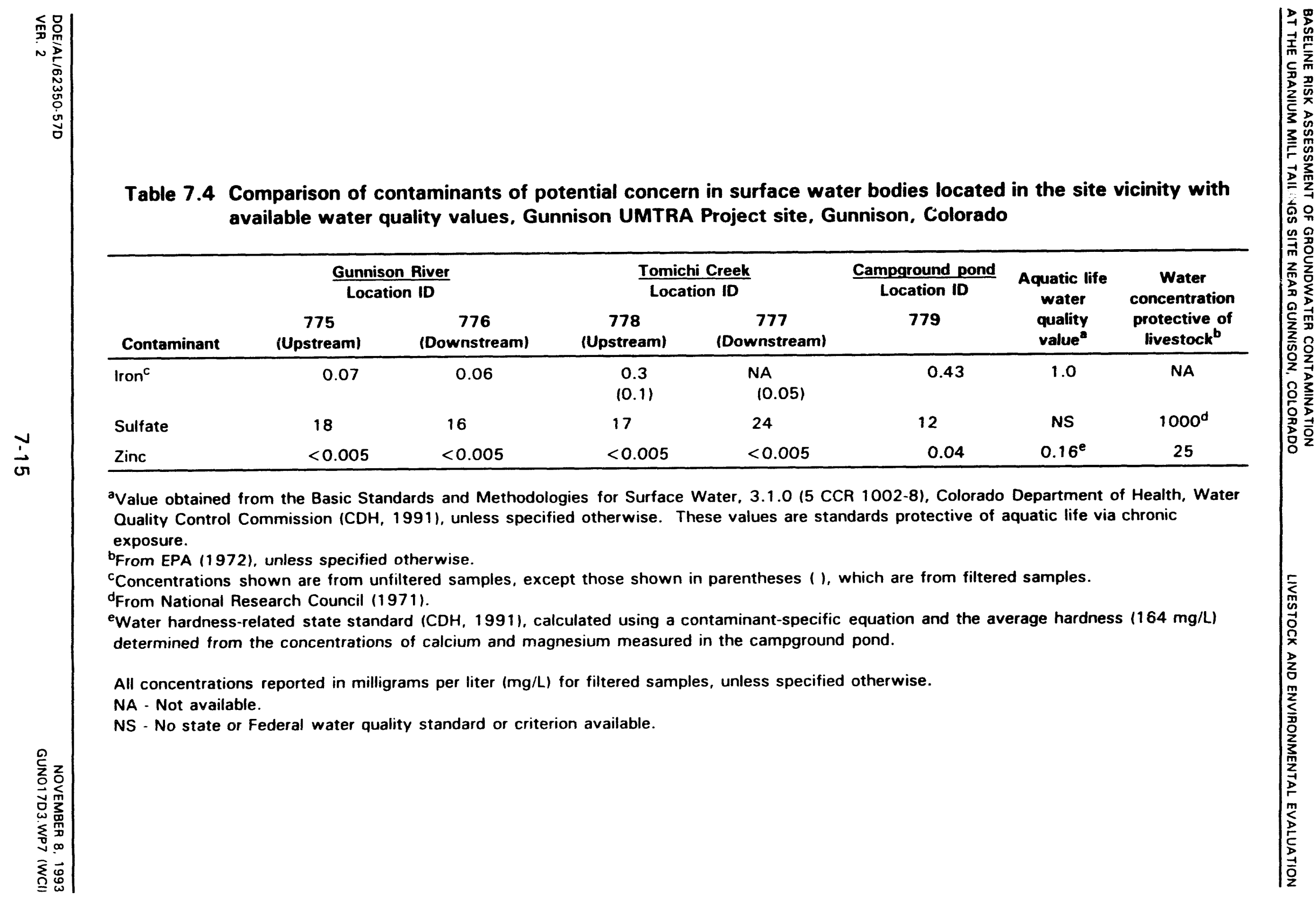


approach has been accepted to adequately develop sediment-based metals criteria (Shea, 1988; Chapman, 1989; EPA, 1989c; NOAA, 1990; Di Toro et al., 1991; Burton, 1991). Therefore, only a qualitative hazard assessment of the metals detected in sediments will be presented in this risk assessment.

National Oceanic and Atmospheric Administration (NOAA) effects-based sediment quality values are available for evaluating the potential for constituents in sediment to cause adverse biological effects. These values are not standards or criteria. Effects rarige-low (ER-L) values are concentrations equivalent to the lower 10th percentile of available data screened by the NOAA and indicate the low end of the range of concentrations in specific sediments at which adverse biological effects were obseived or predicted in sensitive species and/or life stages. The effects range-median (ER-M) values are concentrations based on the NOAA screened data at which effects were observed or predicted in 50 percent of the test organisms evaluated. The NOAA ER-L and ER-M values were compared with the concentrations of the contaminants of concern detected in sediment. One of the limitations of the ER-L and ER-M is that the concentration at which toxicity was observed could not be readily extrapolated from one sediment location to another. Sediment characteristics (e.g., organic carbon content, grain/particle size) greatly influence the contaminant toxicity; thus, the ER-L and ER-M cannot be used as direct indicators of adverse effects to aquatic organisms.

NOAA sediment quality values are available for only one of the detected contaminants of concern, zinc (refer to Table 7.5). The zinc concentrations upstream of the site $(105 \mathrm{mg} / \mathrm{kg})$ and downstream of the site $(110 \mathrm{mg} / \mathrm{kg})$ are below the NOAA ER-L value $(120 \mathrm{mg} / \mathrm{kg})$. This suggests that the potential for zinc to represent a hazard to aquatic life is low. Molybdenum was not detected in the river, in Tomichi Creek, or in the campground pond. Because there are no sediment quality values for manganese and uranium, it is not possible to evaluate whether the detected sediment concentrations could adversely affect biota. However, the concentrations for these two metals were slightly higher at the upstream location than downstream of the site. Although the sediment data base is limited, these data suggest that the site is not acting as a significant release source to the river for sediment-bound metals.

\section{Tomichi Creek water}

One contaminant of potential concern was identified for Tomichi Creek: sulfate (refer to Table 7.4). The concentration of sulfate was approximately 30 percent higher downstream of the site. A statistical evaluation of the data could not be conducted because of the small sample size. Therefore, it is not known whether this higher sulfate concentration is related to site contamination or to other factors (e.g., variability in laboratory analyses).

There are no state or Federal standards or criteria for sulfate. However, when it is considered that the background (i.e., upstream) river water concentration for sulfate is similar to the downstream concentration, it is unlikely that this concentration 
Table 7.5 Comparison of contaminants of potential concern in sediment from surface water bodies located in the site vicinity with available sediment quality values, Gunnison UMTRA Project site, Gunnison, Colorado

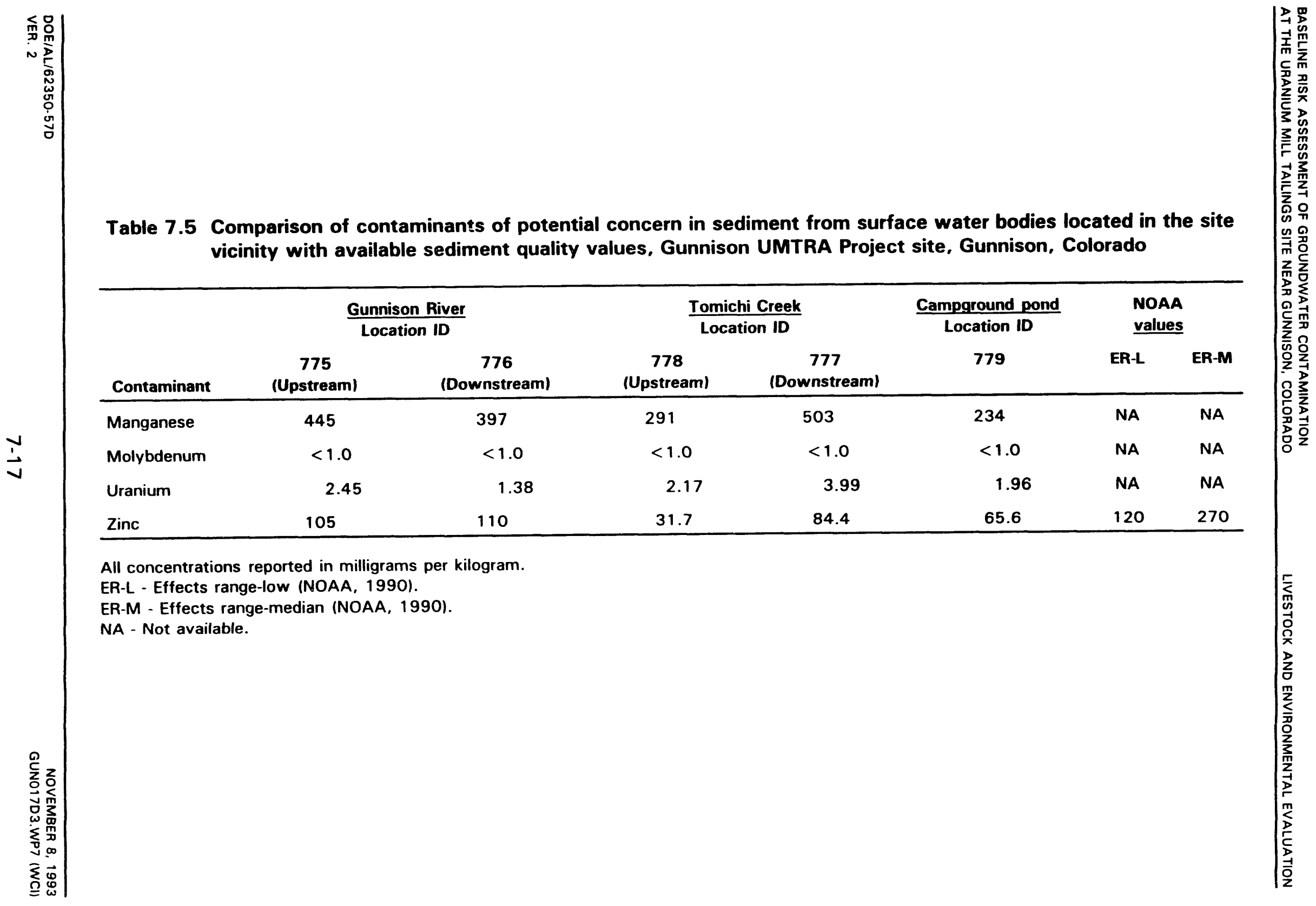


represents an ecological concern. However, continued monitoring of the river is recommended.

\section{Tomichi Creek sediments}

Surficial sediment samples were also collected from Tomichi Creek from the same locations where the surface water was sampled (see Figure 3.11). Molybdenum was not detected at either location. The concentrations for the other analyzed contaminants of potential concern (manganese, uranium, and zinc) were all higher at the downstream location than at the upstream location (Table 7.5). In addition to contaminated groundwater discharge, another potential release source that exists between the upstream and downstream locations on the creek is the water discharge pipe from the gravel pit. Water that has accumulated in the gravel pits is periodically pumped out and into the creek. The downstream concentration increases may be associated with site-related contamination and/or releases not associated with the site; however, insufficient data are available to make a definitive statement.

The detected concentration of zinc at both the upstream location $(31.7 \mathrm{mg} / \mathrm{kg})$ and the downstream location $(84.4 \mathrm{mg} / \mathrm{kg}$ ) are below the NOAA ER-L value of 120 $\mathrm{mg} / \mathrm{kg}$. Because there are no sediment quality values for manganese and uranium, it is not possible to evaluate the potential for these concentrations to represent a hazard to ecological receptors without further study.

\section{Campground pond water}

Two contaminants of potential concern were identified in water collected from the campground pond: iron and zinc (refer to Table 7.4).

A comparison of the surface water data with available water quality values indicates that the concentrations of iron and zinc are below the state standards (refer to Table 7.4). This suggests that the concentrations of iron and zinc would not represent a hazard to aquatic life and that the site is not affecting the water quality in the campground pond. However, concentrations may increase during low flow conditions in the Gunnison River.

\section{Campground pond sediment}

The concentrations of manganese, uranium, and zinc detected in sediment from the campground pond were less than the concentrations detected at the upstream locations in both the Gunnison River and Tomichi Creek. This provides strong evidence that site-related contamination has not affected the sediment quality in this pond. 


\section{Fish tissue}

As described previously (Section 4.2.5), fish were collected from two locations in the Gunnison River and from one location in both Tomichi Creek and the campground pond. The results from the muscle tissue analyses are presented in Table 4.5. The concentrations are presented in units of $\mathrm{mg} / \mathrm{kg}$ dry weight. Manganese was detected at the highest concentration $(3.8 \mathrm{mg} / \mathrm{kg})$ in the fish collected from the upstream Gunnison River location. The concentrations in fish from the other locatioris ranged from $1.1 \mathrm{mg} / \mathrm{kg}$ (campground pond) to $1.9 \mathrm{mg} / \mathrm{kg}$ (downstream locations in both the river and creek). Molybdenum was detected only in the fish collected at the upstream Gunnison River location. Uranium was detected at a concentration of $0.46 \mathrm{mg} / \mathrm{kg}$ in fish tissue from the downstream Gunnison River location. Uranium was not detected $(<0.20 \mathrm{mg} / \mathrm{kg})$ in fish from the other sampling locations. Zinc was detected at similar concentrations in fish tissue from all the sampling locations; the concentrations ranged from $24 \mathrm{mg} / \mathrm{kg}$ to $28.4 \mathrm{mg} / \mathrm{kg}$.

There is little information concerning the relationships between tissue residue levels of contaminants and biological effects in aquatic organisms. In a study involving rainbow trout, no adverse effects were noted in fish having a muscle tissue molybdenum concentration of $7 \mathrm{mg} / \mathrm{kg}$ fresh weight (Short et al., 1971). For comparative purposes, the dry weight concentration of molybdenum detected in the fish tissue sample from the Gunnison River $(0.26 \mathrm{mg} / \mathrm{kg})$ was converted to fresh weight by using the average moisture content of 77 percent from the tissue samples $(0.26$ multiplied by $[1-0.77]=0.06 \mathrm{mg} / \mathrm{kg})$. The converted concentration of $0.06 \mathrm{mg} / \mathrm{kg}$ is less than the concentration of $28 \mathrm{mg} / \mathrm{kg}$ detected in muscle tissue from the literature study (Short et al., 1971).

Manganese concentrations have been reported to range from 0.66 to $3.16 \mathrm{mg} / \mathrm{kg}$ fresh weight in prepared samples (headless, dressed, and homogenized) of northern pike and lake whitefish collected from several Canadian lakes (Uthe and Bligh, 1971). Similarly prepared lake trout collected from a New York lake were reported to contain manganese in concentrations ranging from 0.013 to $0.052 \mathrm{mg} / \mathrm{kg}$ fresh weight (Tong et al., 1974). Converting the detected muscle tissue concentrations from dry weight to fresh weight, the concentrations range from $0.25 \mathrm{mg} / \mathrm{kg}$ fresh weight (campground pond) to $0.87 \mathrm{mg} / \mathrm{kg}$ fresh weight (upstream in Gunnison River). Although these muscle tissue concentrations cannot be compared directly to the available literature data because the literature includes bone and skin, this finding provides a general indication that the concentrations are within the ranges observed in background populations from the literature.

The baseline zinc concentration in muscle tissue of rainbow trout used as control fish in a laboratory study was reported as $20 \mathrm{mg} / \mathrm{kg}$ dry weight (Goettl et al., 1972). The average concentration of zinc in muscle tissue of rainbow trout collected from several lakes used as background sites was approximately $18 \mathrm{mg} / \mathrm{kg}$ dry weight (Densinger et al., 1990). These concentrations are slightly lower than the concentrations reported in muscle tissue samples collected in the site vicinity. 
The uranium concentration in whole-body samples of rainbow trout collected from a background area in a uranium mining district in Washington state ranged from 0.09 to $0.79 \mathrm{mg} / \mathrm{kg}$ dry weight (Nichols and Scholz, 1989). The concentration of uranium detected in the fish muscle tissue sample from the Gunnison River 10.46 $\mathrm{mg} / \mathrm{kg}$ dry weight) is within the background range for whole-body samples reported in the literature. Although a direct comparison cannot be made between the muscle tissue concentration and the whole-body concentration, this finding suggests that the uranium concentration in fish from the river may not be elevated.

Based on the available site-specific data and literature information, there is little compelling evidence suggesting that bioaccumulation is a concern or that the detected muscle tissue concentrations would cause adverse effects to the fish.

\subsection{POTENTIAL IMPACTS TO LIVESTOCK}

Contaminated groundwater may discharge to the downgradient surface water bodies. The potential exists for livestock to drink water from the Gunnison River and/or Tomichi Creek. It is unlikely that livestock currently have access to the campground pond due to its present use as a designated camping area. However, if ownership of this property changes in the future, the pond could be used as a livestock watering pond.

Ingestion by livestock of vegetation that may have bioconcentrated contaminants from alluvial groundwater is a potential pathway. However, without additional data (e.g., actual plant tissue concentrations), it is difficult to evaluate this exposure pathway.

To evaluate the potential impact to livestock that might drink out of the surface water bodies, the detected concentrations were compared to approximate drinking water concentrations considered to be protective of livestock (refer to Table 7.4). Although criteria are available for only three of the contaminants of concern, a comparison of them to the surface water concentrations suggests that livestock could use all the surface water bodies as a source of drinking water.

Based on past and current agricultural activities in the area surrounding the site, the possibility exists that groundwater could be used in the future to provide water for a livestock watering pond. In an attempt to evaluate the potential impact to livestock in this future hypothetical scenario, the mean groundwater concentrations for the contaminants of concern were compared to approximate drinking water concentrations considered to be protective of livestock (EPA, 1972) (refer to Table 7.3). The comparison water quality criterion for sulfate is exceeded by the mean groundwater concentration, while the mean concentrations for cadmium, cobalt, fluoride, and zinc are below the comparison criteria. If this groundwater were used as the sole source of drinking water for livestock, it could result in diarrhea in exposed animals (Church, 1984). No comparison water quality criteria have been reported for the remaining contaminants of concern. However, the available 
information suggests that the use of groundwater as a source of drinking water for livestock may be unacceptable due to sulfate.

\subsection{SUMMARY}

Insufficient water quality and sediment quality values were available to allow a comprehensive evaluation of the impact of surface water, sediments, and contaminated groundwater on ecological receptors.

Surface water data from the water bodies in the site vicinity indicate the presence of slightly higher concentrations for one constituent (sulfate) in Tomichi Creek at the downstream location. None of the constituents in the Gunnison River were detected downstream of the site at concentrations elevated above background levels. Two constituents (iron and zinc) were detected in water from the campground pond at concentrations slightly above background concentrations in the river or creek. However, there is no trend suggesting that site-related constituents have adversely affected the water quality of the creek, river, or pond.

A limited data set currently exists of the sediment quality in the surface water bodies in the vicinity of the site. The data from the Gunnison River suggest that the site is not acting as a source of sediment-bound metals. Sediment concentrations in Tomichi Creek, for the metals which were analyzed, were higher downstream of the site than upstream. Insufficient data are available to determine whether this is due to releases from the site and/or from other sources unrelated to the site. Sediment concentrations in the campground pond are less than those detected at the upstream locations in both the Gunnison River and Tomichi Creek. Concentrations of zinc detected in the river and creek sediments (both upstream and downstream of the site) and in the campground pond are below the available sediment quality values. Sediment quality values are not available for several of the contaminants of concern; thus, it is not possible to evaluate the potential for these concentrations to represent an ecological concern.

Potential exposure to livestock drinking from the water bodies sampled in the site vicinity was evaluated. A comparison of available livestock drinking water quality values with concentrations detected in the surface water bodies suggests that livestock could use these water bodies as their sole drinking water source without adverse health effects. However, the quantity of data is limited, representing only a "snapshot" in time. Additional monitoring, expanded to include the wetland areas, could provide information on possible temporal and seasonal variations in water quality, as well as sediment quality.

Based on available data and criteria, no ecological threat exists to plants that may have roots in contact with soil saturated with the most contaminated groundwater in the alluvial aquifer. This groundwater would not be suitable for continuous use as irrigation water for crops due to cobalt, iron, and manganese. Water from the most contaminated wells in this aquifer would not be suitable as a source of water 
for fish to live in. This groundwater also may not be suitable as a sole source of drinking water for livestock due to the laxative effects of sulfate.

The potential for the contaminants of concern detected in media at the site to represent a food chain hazard (via bioaccumulation and biomagnification) is considered low, based on available surface water, sediment, and fish tissue data. However, other than fish tissue, no tissue analysis from other food chain organisms (e.g., invertebrates and plants) has been conducted. 


\subsection{INTERPRETATION AND RECOMMENDATIONS}

\subsection{RISK SUMMARY}

The UMTRA Project is required by the UMTRCA to protect public health and the environment from radiological and nonradiological hazards associated with the uranium mill sites. This baseline risk assessment was conducted on the Gunnison site to evaluate the presence of these hazards.

Although many domestic wells downgradient of the processing site have been contaminated by site-related constituents, bottled water is available to all residences that are potentially affected by groundwater contamination from the processing site as an interim measure; these residences will be connected to the public water supply system when it is completed in 1994. For the purposes of this risk assessment, potential future use of groundwater from the most contaminated wells at the processing site was evaluated. Health risks would be associated with potential exposures from drinking contaminated groundwater at the site.

Adverse health effects from ingestion of groundwater at the processing site would result from nearly the entire range of potential exposures to manganese and iron, as well as from the upper range of potential exposures to sulfate. Exposures to iron could occur at concentrations that have been fatal to children in acute exposures. Excess lifetime cancer risks associated with drinking water exposure to both median and maximum concentrations of uranium in contaminated groundwater are at levels that exceed the National Contingency Plan criteria $\left(3 \times 10^{-4}\right.$ and $4 \times 10^{-4}$, respectively).

Use of contaminated groundwater from the current or potential future wells downgradient of the site for irrigating crops or gardens and watering livestock is not anticipated to result in human health risks. Adverse human health effects would not be expected following ingestion of milk and meat from animals grazed and watered on the pastureland downgradient of the site or from ingestion of garden produce watered with the contaminated groundwater.

Based on available data, ingestion of fish collected from the water bodies in the site vicinity is not expected to result in adverse human health effects.

The contaminated groundwater near the site would not be acceptable as a source of water for fish to live in, or as a source of continuous irrigation water for agricultural crops. In addition, the groundwater may not be suitable as a sole source of drinking water for livestock due to the laxative effects of sulfate.

The available surface water and sediment data from the water bodies in the site vicinity suggest that contaminated groundwater from the site has not adversely affected the surface water and sediment quality. None of the contaminant levels detected in the surface water and sediments exceeded the available water quality criteria or sediment quality values. 


\subsection{GROUNDWATER CRITERIA}

In 1983, the EPA established health and environmental protection standards for the UMTRA Project, and in 1987 the EPA proposed revised groundwater standards in the UMTRCA. The UMTRA Project is required to adhere to the 1987 proposed groundwater standards until final standards are published. The UMTRCA groundwater standards consist of $1 /$ groundwater protection standards to evaluate disposal cell performance, and 2) groundwater cleanup standards for existing contamination at processing sites. These standards are summarized in Table 8.1 for contaminants that have a proposed maximum concentration limit (MCL). Because an MCL is not established for every contaminant, the proposed standard requires meeting background levels for those contaminants that do not have an $\mathrm{MCL}$.

While the UMTRCA standards apply only to the UMTRA Project, the EPA has also published drinking water health advisory levels for both long- and short-term exposures. These advisories are shown in Table 8.1.

\subsection{RISK MITIGATION MEASURES}

Because there is a potential for serious health effects following short-term use of manganese- and iron-contaminated groundwater at the former processing site, this section presents possible ways to restrict access to groundwater so as to mitigate risks.

Institutional controls are defined in the proposed groundwater standards for the UMTRA Project as mechanisms that can be effectively used to protect human health and the environment by controlling access to contaminated groundwater.

Although the proposed standards refer to institutional controls for long periods of time (e.g., up to 100 years during natural flushing), this concept can also be applied to short-term or interim restriction of access to groundwater. Since not all 24 UMTRA Project sites can be evaluated simultaneously, interim institutional controls may be needed before remedial action decisions are made for individual sites.

At the Gunnison processing site, bottled water has been provided to protect water users on developed land located downgradient from the contaminated plume. A permanent water supply system is currently being constructed and will provide water for domestic use. At present, some of the existing wells are being used to water residential lawns and gardens.

A portion of undeveloped land located downgradient of the contaminated plume does not have an alternate water supply (see Figure 2.7). This area is currently zoned for agricultural use, and water needs for the vegetation are provided by flood irrigation from Tomichi Creek. Any new development in this area would be required by the county to tie onto the alternate water system. The capacity of the water supply system would have to be evaluated should this occur. Any future attempt 
Table 8.1 Concentration limits of constituents

\begin{tabular}{|c|c|c|c|}
\hline Constituent & $\begin{array}{l}\text { UMTRCA MCL } \\
40 \text { CFR } 192.02 \\
\text { (mg/L) }\end{array}$ & $\begin{array}{l}\text { Health advisories } \\
\text { 10-kg child, 10-day } \\
\text { (mg/L) }\end{array}$ & $\begin{array}{c}\text { Health advisories } \\
70-\mathrm{kg} \text { adult lifetime } \\
\text { (mg/L) }\end{array}$ \\
\hline \multicolumn{4}{|l|}{ Chemicals (inorganic) } \\
\hline Antimony & - & 0.015 & 0.003 \\
\hline Arsenic & 0.05 & $\cdot$ & - \\
\hline Barium & 1.0 & - & 2 \\
\hline Boron & - & 0.9 & 0.6 \\
\hline Cadmium & 0.01 & 0.04 & 0.005 \\
\hline Chromium & 0.05 & 1.0 & 0.1 \\
\hline Cobalt & - & $\cdot$ & $\cdot$ \\
\hline Copper & - & - & - \\
\hline Fluoride & - & - & - \\
\hline Iron & $\cdot$ & - & - \\
\hline Lead & 0.05 & $\cdot$ & 0.015 \\
\hline Manganese & - & - & - \\
\hline Mercury & 0.002 & $\cdot$ & $\cdot$ \\
\hline Molybdenum & 0.1 & 0.08 & 0.04 \\
\hline Nickel & - & 1.0 & 0.1 \\
\hline Nitrate & $44^{a, b}$ & $44^{c}$ & - \\
\hline Selenium & $0.01^{a}$ & - & - \\
\hline Silver & 0.05 & 0.2 & 0.1 \\
\hline Strontium & - & 25 & 17 \\
\hline Sulfate & - & - & - \\
\hline Thallium & - & 0.007 & 0.0004 \\
\hline Vanadium & - & 0.08 & 0.02 \\
\hline Zinc & - & 6.0 & 2 \\
\hline \multicolumn{4}{|l|}{ Radionuclides } \\
\hline Lead-210 & - & - & - \\
\hline Polonium-210 & - & - & - \\
\hline Radium-226/-228 & $5 \mathrm{pCi} / \mathrm{L}$ & - & - \\
\hline Thorium-230 & - & - & - \\
\hline $\begin{array}{l}\text { Uranium } \\
(U-234 /-238)\end{array}$ & $\begin{array}{r}30 \mathrm{pCi} / \mathrm{L}^{\mathrm{a}} \\
(0.044 \mathrm{mg} / \mathrm{L})\end{array}$ & - & - \\
\hline
\end{tabular}

$N A=$ No RfD available with which to calculate a health-based concentration.

${ }^{a}$ Exceeded in plume wells.

${ }^{b}$ Equal $10 \mathrm{mg} / \mathrm{L}$ nitrate as nitrogen.

cUnder review. 
at development would require a change in zoning through application to the county. The placement of any wells would be regulated through either the county or the state, depending on well depth.

\section{Well permits}

All of the Colorado UMTRA Project sites are located on the Colorado west slope and are outside the designated groundwater basins. Construction of a well in Colorado outside the designated basins requires a written application to the state engineer for a permit to construct a new well. Designated basins are isolated hydrogeologic areas where groundwater use is stringently evaluated based on the demands for water rights. The state engineer is required to act on applications for new well permits within 45 days after their receipt. If a well would affect existing water rights or if an applicant wanted to establish a legal right, adjudication would likely be required prior to the permit being granted.

\section{Groundwater quality}

The Colorado Department of Health is the state agency responsible for setting water quality standards. Within the Colorado Department of Health, the State Water Quality Control Commission is responsible for adopting the water quality standards and classifications for state waters in Colorado.

The state of Colorado proposed groundwater quality standards require that groundwater be free of substances in concentrations shown to be "carcinogenic, mutagenic, teratogenic or toxic to human beings and/or a danger to public health, safety, or welfare" (CDH, 1990).

The state engineer is authorized to enforce the state groundwater quality standards. However, the state engineer does not have jurisdiction to deny a permit for drilling a new well based on water quality. The state engineer's office can issue a warning to well users if the well is placed in a known contaminated aquifer. Private domestic well water quality is not regulated by the state. Well water to be consumed by 25 or more people does have to meet water quality standards, and use can be restricted by the Colorado Department of Health, Water Quality Control Division, Drinking Water Section.

\section{Land use regulations}

Any change in land use in Gunnison County would require a land use change permit. The permit is issued by the Gunnison County Board of Commissioners. Since the processing site and the surrounding land are located outside the city limits of Gunnison, city zoning restrictions do not apply. 
Gunnison County's land use policies are set forth in a 1984 land use resolution. One of the policies of the resolution is "to ensure that adequate water in terms of quality, quantity, and dependability is both legally and actually available to development approved within Gunnison County" (Gunnison County Planning Department, 1984). The County Planning Department can designate an area a hazard zone if the criteria listed in the land use resolution are met.

Establishing interim institutional controls to protect human health and the environmeni would require a consensus among the state of Colorado governing agencies and the Gunnison County Planning Commission. Governing authorities would need to be informed of groundwater monitoring results and the anticipated duration of contamination problems. The presence of a public water supply system largely reduces the likelihood of groundwater being used for domestic consumption at this site.

\subsection{FUTURE SITE ACTIVITIES}

Water quality monitoring at the Gunnison processing site and vicinity involves site characterization and health-protection monitoring at the former processing site and in the Dos Rios subdivision. Future groundwater monitoring of private domestic wells is advisable in the Dos Rios subdivision for the following reasons:

- Although the DOE has already committed to providing an alternate water supply system, a provision has been made to monitor a "buffer zone" of representative domestic wells in Unit 2 of the Dos Rios subdivision. The buffer zone is downgradient from the area covered by the water distribution system.

- The water distribution system will be connected to households for potable water consumption and washing. Water necessary for irrigation and livestock may be withdrawn from private irrigation wells. Groundwater withdrawn from these irrigation wells should be monitored to provide assurance that the water quality remains suitable for irrigation and livestock watering.

If a notable increase in the concentration of a contaminant is detected, several activities will be conducted to determine whether the increase indicates a significant change in water quality. Increases in analyte concentrations can occur for various reasons, including 1 ) artifacts of sample collection and laboratory analysis procedures, 2) changes in background water quality, 3) changes in the environment that are unrelated to uranium processing activities, and 4 ) a single localized "pulse" in the geochemical environment. Activities to determine the nature and extent of an increase in concentration may include reanalysis, resampling, comparison to other geochemical parameters, and trend analysis. If the increase is significant and perceived to be a "health threat," the $\mathrm{CDH}$ and DOE will consult to evaluate potential actions.

As additional water quality data are collected and interpreted, the groundwater sampling plan for the Gunnison site will be updated annually to provide ongoing 
protection for public health and the environment, including future groundwater monitoring of private domestic wells in the Dos Rios subdivision.

Most of the site characterization activities conducted to date at the Gunnison processing site were intended to provide sufficient preliminary site characterization information to design and implement a surface remediation plan (for relocating the residual radioactive materials to the Gunnison disposal site). The results of the hydrogeologic testing were not intended to provide a conclusive hydrogeologic characterization of the Gunnison processing site and are considered to be estimated values. Additional site characterization activities will be conducted during the groundwater restoration phase of the UMTRA Project. These site characterization activities may include additional aquifer performance testing, installation and sampling of additional monitor wells, and installation of surface water level recorders and staff gages at the Gunnison River.

It is recommended that water levels be concurrently monitored in well clusters near the Gunnison River and in the river. This will provide information on the relationship between groundwater and surface water.

Additional sampling should be conducted to better evaluate the potential for ecological impact. These sampling efforts would further evaluate the potential for surface water, sediment, and biota contamination and provide information on temporal or seasonal variations. If these results indicate a significant potential for adverse effects, additional studies might include toxicity tests, quantitative investigations, or biomonitoring. No surface water or sediment samples have been collected to date from the wetland areas in the site vicinity. It would be beneficial to collect some samples from the areas to provide baseline data.

\subsection{RECOMMENDATIONS}

In general, the proposed groundwater standards consisting of MCLs or background concentrations are sufficient to protect human health and the environment. However, in some cases, a risk assessment may identify site-specific factors that suggest these standards may either be too restrictive or not restrictive enough. When standards are too restrictive, there may be no potential for exposure, and a less restrictive alternate concentration limit $(A C L)$ may be sought. In other cases, the standards may not be sufficiently protective (e.g., if there are many contaminants near the MCL with additive or synergistic adverse health effects).

At Gunnison, no permanent physical barrier prevents access to contaminated groundwater at the former processing site. Therefore, ACLs are not likely to be justified for those constituents with MCLs. However, for those constituents that exceed background levels and do not have MCLs, this assessment suggests that background levels are more restrictive than necessary. This includes contaminants screened because their concentrations fall within nutritional levels (e.g., zinc) and other contaminants such as cobalt, nickel, and strontium that were demonstrated to 
be at concentrations well below adverse health effect levels. ACLs should be sought for these contaminants.

Some fundamental questions about the hydrology and geochemistry of the Gunnison site must be answered before the risk associated with this site can be fully determined. As discussed in Section 3.2, there is geochemical evidence suggesting that the leading edge of the contaminant plume may pass beneath the Gunnison River at depth. Additional monitor wells, stream gauge recorders, and staff gauges should be installed so that the physical and chemical interactions between surface water and groundwater and the vertical and horizontal alluvial groundwater flow system at and in the vicinity of the Dos Rios subdivision can be better characterized.

There is significant evidence that the alluvial aquifer is chemically stratified. A series of well clusters should be tested for variations in redox potential. If more reducing conditions are present in the more deeply screened monitor wells, this could explain the presence of elevated manganese in deeply screened wells that are paired with shallower wells containing little or no manganese.

Given the toxicity of the elevated levels of iron and particularly manganese present in the plume proximal to the tailings pile, batch and column tests should be used to develop site specific Kd's for manganese and iron. This would allow the quantitative assessment of the transport and fate of these constituents.

Because of the potential for contaminant migration, an institutional control that advises against installation of high-capacity production wells on the west side of the Gunnison River may be warranted.

It is recommended that an additional round of surface water and sediment samples be collected from the water bodies located in the vicinity of the site during a lowflow period in the Gunnison River and Tomichi Creek. It is also recommended that samples of plant and additional animal tissue be collected from the site vicinity and from a background location. These data would be necessary for assessing bioaccumulation and the potent'A for food chain transfer. 


\subsection{LIST OF CONTRIBUTORS}

The following individuals contributed to the preparation of this report.

\begin{tabular}{ll}
\hline Name & Contribution \\
\hline C. Day, J. Lewis & Overall document responsibility; authorship \\
L. Flowers & Technical review \\
C. Day & Ecological assessment \\
K. Smith & Statistical evaluation \\
K. Monks & Hydrogeology \\
J. Blount & Geochemistry \\
R. Neri Zegal & Institutional controls \\
L. Flowers, J. Lewis & Toxicology \\
J. Crain & Surface water \\
C. Slosberg, & Word processing \\
WordCenter, Inc. & Graphic design \\
E. Bond & Technical editing \\
D. Thalley &
\end{tabular}




\subsection{REFERENCES}

ATSDR (Agency for Toxic Substances and Disease Registry), 1991. "Draft Toxicological Profile for Cobalt," U.S. Department of Health and Human Services, Atlanta, Georgia.

Baes et al. (C. F. Baes III, R. D. Sharp, A. L. Sjoreen, and R. W. Shor), 1984. A Review and Analysis of Parameters for Assessing Transport of Environmentally Released Radionuclides Through Agriculture, ORNL-5786, prepared for Oak Ridge National Laboratory, Health and Safety Research Division, Oak Ridge, Tennessee.

Ballou et al. (J. E. Ballou, R. A. Gies, A. C. Case, D. L. Haggard, R. L. Buschbom, and J. L. Ryan), 1986. "Deposition and Early Disposition of Inhaled Uranium-233 Uranyl Nitrate and Uranium-232 Uranyl Nitrate in the Rat," Health Physics, No. 51, pp. 755-772.

Berlin, M., and B. Rudell, 1986. "Uranium," in Handbook on the Toxicology of Metals, second edition, L. Friberg, G. F. Nordberg, and V. B. Vouk, eds., pp. 647-658, Elsevier Science Publishers, Amsterdam.

Bernard, S. R., and K. F. Brown, 1978. "Distribution of Mammals, Reptiles, and Amphibians by BLM Physiographic Regions and A. W. Kuchlers Associations for the Eleven Western States," U.S. Department of the Interior, Bureau of Land Management, Denver, Colorado.

Burton, G. A., Jr., 1991. "Assessing the Toxicity of Freshwater Sediments," Environmental Toxicology and Chemistry, No. 10, pp. 1585-1627.

Carlson, L. W., 1989. Colorado State Supervisor, Fish and Wildlife Service, Golden, Colorado, personal communication with Bill Glover, Environmental Services, Jacobs Engineering Group Inc., Albuquerque, New Mexico, September 26, 1989.

Casarett, L. J., and J. Doull, 1991. Toxicology: The Basic Science of Poisons, fourth edition, M. O. Amdur, J. Doull, and C. D. Klaassen, eds., Pergamon Press, New York, New York.

CDH (Colorado Department of Health), 1991. Basic Standards and Methodologies for Surface Water, 3.1.0., Water Quality Control Commission, Denver, Colorado.

CDH (Colorado Department of Health), 1990. "Ground Water Quality Standards," 3.11.5A, The Basic Standards for Ground Water, Water Quality Control Commission, Denver, Colorado.

CDM (Camp, Dresser, \& McKee), 1981. "Chance Gulch Environmental Report," prepared for AMAX, Inc., Golden, Colorado. 
CDW (Colorado Division of Wildlife), 1993. "Electrofishing Records for the Gunnison River and Lower Tomichi Creek," correspondence from Sherman Hebein, CDW wildlife biologist, to Chris Day of the Technical Assistance Contractor, COL/JEG/0893. 0001 , August 4, 1993.

Chapman, P. M., 1989. "Current Approaches to Developing Sediment Quality Criteria," Environmental Toxicology and Chemistry, No. 8, pp. 598-599.

Church, D.C., 1984. Livestock Feeds and Feeding, second edition, McGraw-Hill Publishing Co., New York, New York.

Cothern, C. R., and W. L. Lappenbusch, 1983. "Occurrence of Uranium in Drinking Water in the United States," Health Physics, No. 45, pp. 89-99.

Davis, S. N., and R. J. M. DeWeist, 1966. Hydrology, John Wiley and Sons, Inc., New York, New York.

Densinger et al. (J. Densinger, L. J. Erickson, A. Austin, M. Roch, and M. J. R. Clark), 1990. "The Effects of Decreasing Heavy Metal Concentrations on the Biota of Buttle Lake, Vancouver Island, British Colombia," Water Research, No. 24(4), pp. 403-416.

Di Toro et al. (D. M. Di Toro, C. S. Zarba, D. J. Hansen, W. J. Berry, R. C. Swartz, C. E. Cowan, S. P. Pavlou, H. E. Allen, N. A. Thomas, and P. R. Paquin), 1991. "Technical Basis for Establishing Sediment Quality Criteria for Nonionic Organic Chemicals Using Equilibrium Partitioning," Environmental Toxicology and Chemistry, No. 10, pp. 1541-1583.

DOE (U.S. Department of Energy), 1993. Programmatic Environmental Impact Statement for the Uranium Mill Tailings Remedial Action Ground Water Project, draft, DOE/AL/62350-32D, September 1993, prepared by the U.S. Department of Energy, UMTRA Project Office, Albuquerque Operations Office, Albuquerque, New Mexico.

DOE (U.S. Department of Energy), 1992a. Remedial Action Plan and Site Design for Stabilization of the Inactive Uranium Mill Tailings Site at Gunnison, Colorado, UMTRA-DOE/AL-050508.0000, DOE UMTRA Project Office, Albuquerque Operations Office, Albuquerque, New Mexico.

DOE (U.S. Department of Energy), 1992b. Environmental Assessment of Remedial Action at the Gunnison Uranium Mill Tailings Site Near Gunnison, Colorado, DOE/EA-0376, DOE UMTRA Project Office, Albuquerque Operations Office, Albuquerque, New Mexico.

DOE (U.S. Department of Energy), 1991. Environmental Assessment of the Provision of a Water Supply System, Gunnison, Colorado, DOE/EA-0529, DOE UMTRA Project Office, Albuquerque Operations Office, Albuquerque, New Mexico. 
DOE (U.S. Department of Energy), 1990. "Baseline Risk Assessment for Groundwater Contamination at the Uranium Mill Tailings Site in Gunnison, Colorado," JEGA/UMT/1190-0569, DOE UMTRA Project Office, Albuquerque Operations Office, Albuquerque, New Mexico.

Duckham, J. M., and H. A. Lee, 1976. "The Treatment of Refractory Anaemia of Chronic Renal Failure with Cobalt Chloride," Quarterly Journal of Medicine, No. 45 (178), pp. 351-372.

EES (Ecosphere Environmental Services), 1991. "A Threatened and Endangered Species Survey of the Sixmile Lane and Chance Gulch Borrow Sites and the Tenderfoot Mountain Haul Route Alternatives," prepared by EES, Farmington, New Mexico, for MK-Ferguson Company.

Elinder, C. G., 1986. "Iron," Handbook on the Toxicology of Metals, L. Friberg, G. F. Nordberg, and V. Houk, eds., second edition, Elsevier Science Publishers, Amsterdam.

EPA (U.S. Environmental Protection Agency), 1993. Integrated Risk Information System (IRIS), data base, Office of Research and Development, Washington, D.C.

EPA (U.S. Environmental Protection Agency), 1992. Toxic Substances Spreadsheet, Region IV, Atlanta, Georgia.

EPA (U.S. Environmental Protection Agency), 1989a. "Drinking Water Criteria Document for Uranium," external review draft, Criteria and Standards Division, Office of Drinking Water, Washington, D.C.

EPA (U.S. Environmental Protection Agency), 1989b. Risk Assessment Guidance for Superfund, Vol. II, Environmental Evaluation Manual, EPA/504/1-89/001, Office of Emergency and Remedial Response, Washington, D.C.

EPA (U.S. Environmental Protection Agency), 1989c. "Briefing Report to the EPA Science Advisory Board on the Equilibrium Partitioning Approach to Generating Sediment Quality Criteria," Office of Water Regulations and Standards, Washington, D.C.

EPA (U.S. Environmental Protection Agency), 1988. Interim Sediment Quality Criteria Values for Nonpolar Hydrophobic Organic Contaminants, Office of Water Regulations and Standards, Washington, D.C.

EPA (U.S. Environmental Protection Agency), 1972. Water Quality Criteria, National Academy of Sciences and National Academy of Engineering, Washington, D.C.

FBDU (Ford, Bacon and Davis Utah, Inc.), 1981. Engineering Assessment of Inactive Uranium Mill Tailings, Gunnison Site, Gunnison, Colorado, DOE/UMT-107, Salt Lake City, Utah. 
Fisenne et al. (I. M. Fisenne, P. M. Perry, and N. H. Harley, 1988. "Uranium in Humans," Radiation Protection Dosimetry, No. 24, pp. 127-131.

Flanagan et al. (P. R. Flanagan, J. S. McLellan, J. Haist, M. G. Cherian, M. J. Chamberlain, and L. S. Valbergl, 1978. Gastroenterology, Vol. 74, pp. 841-846.

Freeze, R. A., and J. A. Cherry, 1979. Ground-Water, Prentice-Hall, Inc., Englewood Cliffs, New Jersey.

Friberg et al. (L. Friberg, G. F. Nordberg, and V. B. Vouk), 1986. Handbook on the Toxicology of Metals, Volume II: Specific Metals, second edition, Elsevier, New York, New York.

Goettl et al. (J. P. Goettl, Jr., J. R. Sinley, and P. H. Davies), 1972. "Study of the Effects of Metallic lons on Fish and Aquatic Organisms, Baseline Level of Zinc and Copper in Rainbow Trout," Water Pollution Studies, Job Prog. Rep., Fed. Aid Proj. F-33-R7. Colorado Division of Wildlife, Fort Collins, Colorado, pp. 42-45.

Goyer, Robert A., 1991. "Toxic Effects of Metals," Casarett and Doull's Toxicology: The Basic Science of Poisons, pp. 623-680, fourth edition, M. O. Amdur, J. Doull, and C. D. Klaassen, eds., Pergamon Press, New York, New York.

Gunnison County Planning Department, 1984. Gunnison County Land Use Resolution, second edition, May 8, 1984, Gunnison, Colorado.

Hammerson, G. A., 1986. Amphibians and Reptiles in Colorado, Colorado Division of Wildlife, Denver, Colorado.

Hem, J. D., 1970. Study and Interpretation of the Chemical Characteristics of Natural Water, U.S. Geological Survey Water Supply Paper 1476, 363 pp.

Josephs, H. W., 1958. "Absorption of Iron as a Problem in Human Physiology," Blood, No. 13, pp. 1-54.

Kabata-Pendias, A., and H. Pendias, 1992. Trace Elements in Soils and Plants, second edition, CRC Press, Boca Raton, Florida.

Kenaga, E. E., 1980. "Predicted Bioconcentration Factors and Soil Sorption Coefficients of Pesticides and Other Chemicals," Ecotoxicology and Environmental Safety, No. 4. pp. 26-38.

Kjellström, T., 1979. Environmental Health Perspective, Vol. 28, pp. 169-197.

Kondakis, et al. (X. G., N. Makris, M. Leotsinidis, M. Prinou, and T. Papapetropoulos), 1989. "Possible Health Effects of High Manganese Concentration in Drinking Water," Archives of Environmental Health, 1989, Vol. 44, No. 3, pp. 175-178. 
Leach et al. (L. J. Leach, R. M. Gelein, B. J. Panner, C. L. Ylie, and C. C. Cox), 1984. The Acute Toxicity of the Hydrolysis Products of Uranium Hexafluoride (UF6) When Inhaled by the Rat and Guinea Pig, final report, ISS K/SUB-81-9039-3, NTIS DE84011539.

Lönnerdal et al. (B. Lönnerdal, C. L. Keen, J. G. Bell, and B. Sandstrom), 1987. "Manganese Uptake and Retention," Nutritional Bioavailability of Manganese, C. Kies, ed., American Chemical Society, symposium series 354, pp. 9-20, American Chemical Society, Washington, D.C.

Maynard, E. A., and H. C. Hodge, 1949. "Study of Toxicity of Various Uranium Compounds When Fed to Experimental Animals," Pharmacology and Toxicology of Uranium Compounds, National Nuclear Energy Services, Div. VI, Vol. 1, pp. 309 376, C. Voegtlin and H. C. Hodge, eds., McGraw Hill, New York, New York.

Mena et al. (I. Mena, K. Horiuchi, K. Burke, and G. C. Cotzias), 1969. "Chronic Manganese Poisoning. Individual Susceptibility and Absorption of Iron," Neurology, No. 19, pp. 1000-1006.

Moriarty, F., 1988. Ecotoxicology: The Study of Pollutants in Ecosystems, second edition, Academic Press, New York, New York.

National Research Council, 1980. Drinking Water and Health, Volume 3, Safe Drinking Water Committee.

National Research Council, 1971. Nutrient Requirements of Dairy Cattle, Committee on Animal Nutrition, fourth edition, The National Academy of Science, Washington, D.C.

NCRP (National Council on Radiation Protection and Measurements), 1984. "Exposures from the Uranium Series with Emphasis on Radon and its Daughter," NCRP Report No. 77, Bethesda, Maryland.

Nichols, D. G., and A. T. Scholz, 1989. "Concentrations of Cadmium, Strontium, and Uranium in Fish and Water Samples Collected from a Small Stream Receiving Uranium Mine Discharge," Journal of Freshwater Ecology, No. 5(1), pp. 13-25.

Nordberg et al. (G. F. Nordberg, T. Kjellström, and M. Nordberg), 1985. Cadmium and Health: a Toxicological and Epidemiological Appraisal, L. Friberg, C. G. Elinder, T. Kjellström, and G. F. Nordberg, eds., CRC Press, Boca Raton, Florida.

NOAA (National Oceanic and Atmospheric Administration), 1990. "The Potential for Biological Effects of Sediment-Sorbed Contaminants Tested in the National Status and Trends Program," NOAA technical memo, NOS OMA 52.

NOAA (National Oceanic and Atmospheric Administration), 1984. "Climatography of the United States No. 20, Gunnison, Colorado, for the Period 1951-80," National Climatic Center, Federal Building, Asheville, North Carolina. 
NUREG (Nuclear Regulatory Agency), 1986. Update of Part 61, Impacts Analysis Methodology. Div. Waste Mgmt, Office Nuclear Material Safety and Safeguards, NUREG/CR-4370, Vol. 1.

Palisade Corporation, 1992. @RISK, Risk Analysis and Simulation Add-In for Lotus 1-2-3, Version 2.01, Newfield, New York.

PNL (Pacific Northwest Laboratory), 1989. "Sorption Distribution Coefficient Data," Multimedia Environmental Pollutant Assessment System, Pacific Northwest Laboratory, Richland, Washington.

Prister, B. S., 1969. GKIAE Report by Atomizdat, Moscow (Canadian translation AEC/TR/7178 (1970), and USCEAR Rep. A/AC.82/G/L 1298).

Rai, D., and J. M. Zachara, 1984. Chemical Attenuation Rates, Coefficients, and Constants in Leachate Migration, Volume 1: A Critical Review, Electric Power Research Institute, Palo Alto, California.

Roseberry, A. M., and D. E. Burmaster, 1992. "Lognormal Distributions for Water Intake by Children and Adults," Risk Analysis, Vol. 12, No. 1, pp. 99-104.

Saric, M., 1986. "Manganese," Handbook on the Toxicology of Metals, Volume II, pp. 354.386, L. Friberg, G. F. Nordberg, V. B. Vouk, eds., Elsevier, New York.

Shea, D., 1988. "Developing National Sediment Quality Criteria," Environmental and Scientific Technology, No. 22(11), pp. 1256-1261.

Short et al. (Z. F. Short, P. R. Olson, R. F. Palumbo, J. R. Donaldson, and F. G. Lowman), 1971. "Uptake of Molybdenum, Marked with 99Mo, by the Biota of Fern Lake, Washington, in a Laboratory and a Field Experiment," Radionuclides in Ecosystems, Proceedings of the Third National Symposium on Radioecology, Vol. 1, pp. 474485, D. J. Nelson, ed., May 10-12, 1971, Oak Ridge, Tennessee.

Stevens et al. IW. F. Stevens, W. Bruenger, D. R. Atherton, J. M. Smith, and G. N. Taylor), 1980. "The Distribution and Retention of Hexavalent ${ }^{233} \mathrm{U}$ in the Beagle," Radiation Research, No. 83, pp. 109-126.

Sullivan et al. (M. F. Sullivan, P. S. Ruemmler, J. L. Ryan, and R. L. Bushhom), 1986. "Influence of Oxidizing or Reducing Agents on Gastrointestinal Absorption of U, Pu, Am, Cm, and Pm by Rats," Health Physics, No. 50, pp. 223-232.

TAC (Technical Assistance Contractor), 1990. "Unpublished Field Notes, Gunnison, Colorado, Uranium Mill Tailings Site," unpublished report prepared by the TAC (Jacobs-Weston Team), Albuquerque, New Mexico, for the U.S. Department of Energy, UMTRA Project Office, Albuquerque Operations Office, Albuquerque, New Mexico. 
TAC (Technical Assistance Contractor), 1989. "Unpublished Field Notes, Gunnison, Colorado, Uranium Mill Tailings Site," unpublished report prepared by the TAC (Jacobs-Weston Team), Albuquerque, New Mexico, for the U.S. Department of Energy, UMTRA Project Office, Albuquerque Operations Office, Albuquerque, New Mexico.

TAC (Technical Assistance Contractor), 1988. "Unpublished Field Notes, Gunnison, Colorado, Uranium Mill Tailings Site," unpublished report prepared by the TAC (Jacobs-Weston Team), Albuquerque, New Mexico, for the U.S. Department of Energy, UMTRA Project Office, Albuquerque Operations Office, Albuquerque, New Mexico.

TAC (Technical Assistance Contractor), 1986. "Unpublished Field Notes, Gunnison, Colorado, Uranium Mill Tailings Site," unpublished report prepared by the TAC (Jacobs-Weston Team), Albuquerque, New Mexico, for the U.S. Department of Energy, UMTRA Project Office, Albuquerque Operations Office, Albuquerque, New Mexico.

TAC (Technical Assistance Contractor), 1985. "Unpublished Field Notes, Gunnison, Colorado, Uranium Mill Tailings Site," unpublished report prepared by the TAC (Jacobs-Weston Team), Albuquerque, New Mexico, for the U.S. Department of Energy, UMTRA Project Office, Albuquerque Operations Office, Albuquerque, New Mexico.

Tong et al. (S. S. C. Tong, W. D. Youngs, W. H. Gutenmann, and D. J. Lisk), 1974. "Trace Metals in Lake Cayuga Lake Trout (Salvelinus namaycush) in Relation to Age," Journal of the Fisheries Resource Board of Canada, No. 31(2), pp. 238-239.

Tracy et al. (B. L. Tracy, J. M. Quinn, J. Lahey, A. P. Gilman, K. Mancuso, A. P. Yagdinas, and D. C. Villeneuve), 1992. "Absorption and Retention of Uranium from Drinking Water by Rats and Rabbits," Health Physics, Vol. 62, pp. 65-73.

Tracy et al. (B. L. Tracy, F. A. Prantl, and J. M. Quinn), 1983. "Transfer of ${ }^{226} \mathrm{Ra}{ }^{210} \mathrm{~Pb}$, and Uranium from Soil to Garden Produce: Assessment of Risk," Health Physics, Vol. 44, p. 469.

USGS (U.S. Geological Survey), 1984. Water Resources Data, Colorado, Water Year 1983, U.S. Geological Survey Water Survey Data Report C0-83-2, National Technical Information Service, Springfield, Virginia.

Uthe, J. F., and E. G. Bligh, 1971. "Preliminary Survey of Heavy Metal Contamination of Canadian Freshwater Fish," Journal of the Fisheries Resource Board of Canada, No. 28(5), pp. 786-788.

Weigel, F., 1983. "Uranium and Uranium Compounds," Kirk-Othmer Encyclopedia of Chemical Technology, Vol. 23, third edition, pp. 502-547, M. Grayson, ed., John Wiley and Sons, New York, New York. 
Whitney et al. (E. N. Whitney, E. M. Hamilton, and S. R. Roth), 1990. Understanding Nutrition, fifth edition, West Publishing Co., St. Louis, Missouri.

Wrenn et al. (M. E. Wrenn, P. W. Durbin, B. Howard, J. Lipsztein, J. Rundo, E. T. Still, and D. L. Willis), 1985. "Metabolism of Ingested $U$ and Ra," Hea/th Physics, No. 48, pp. 601-633.

\section{PUBLIC LAWS}

PL 95-604 (Public Law 95-604), 1978. Uranium Mill Tailings Radiation Control Act of 1978, 42 USC 7901, November 8, 1978, 95th Congress of the United States of America, Washington, D.C.

\section{CODE OF FEDERAL REGULATIONS}

40 CFR 192, "Health and Environmental Protection Standards for Uranium and Thorium Mill Tailings," Title 40, Code of Federal Regulations, Part 192, U.S. Environmental Protection Agency, Office of the Federal Register National Archives and Records Administration, Washington, D.C. 

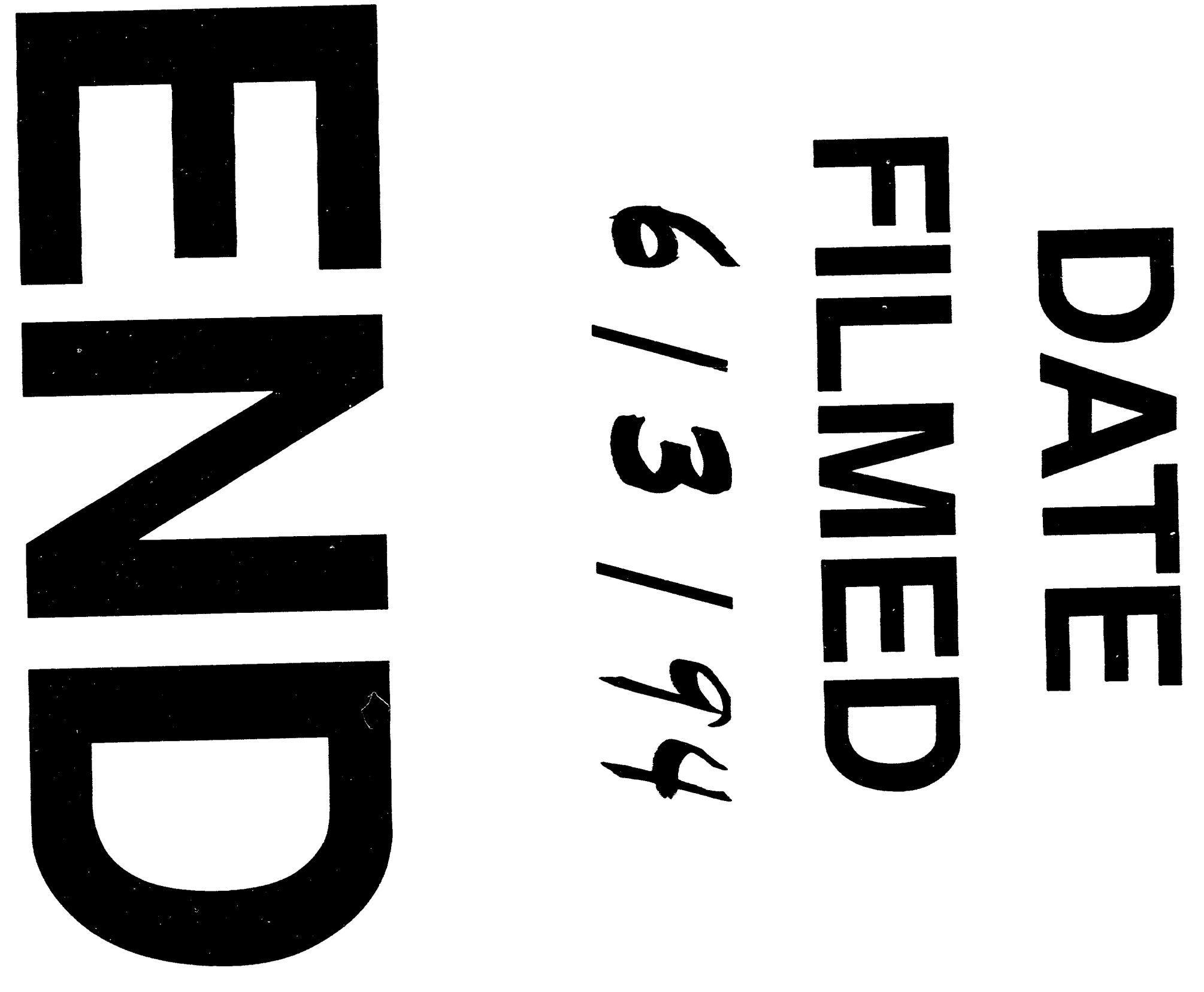